\title{
CAMPI SUSTENTÁVEIS: \\ desafios para a construção de espaços universitários
}

Dissertação apresentada ao Programa de Pós-Graduação em Arquitetura e Urbanismo do Instituto de Arquitetura

e Urbanismo da Universidade de São Paulo para a obtenção do título de mestre em Arquitetura e

Urbanismo.

Área de concentração:

Teoria e História da Arquitetura e Urbanismo

Orientadora:

Profa. Dra. Luciana Bongiovanni Martins Schenk

São Carlos, 2017

(Versão corrigida) 
AUTORIZO A REPRODUÇÃO E DIVULGAÇÃO TOTAL OU PARCIAL DESTE TRABALHO, POR QUALQUER MEIO CONVENCIONAL OU ELETRÔNICO, PARA FINS DE ESTUDO E PESQUISA, DESDE QUE CITADA A FONTE.

Ficha catalográfica elaborada pela Biblioteca do Instituto de Arquitetura e Urbanismo

com os dados fornecidos pelo(a) autor(a)

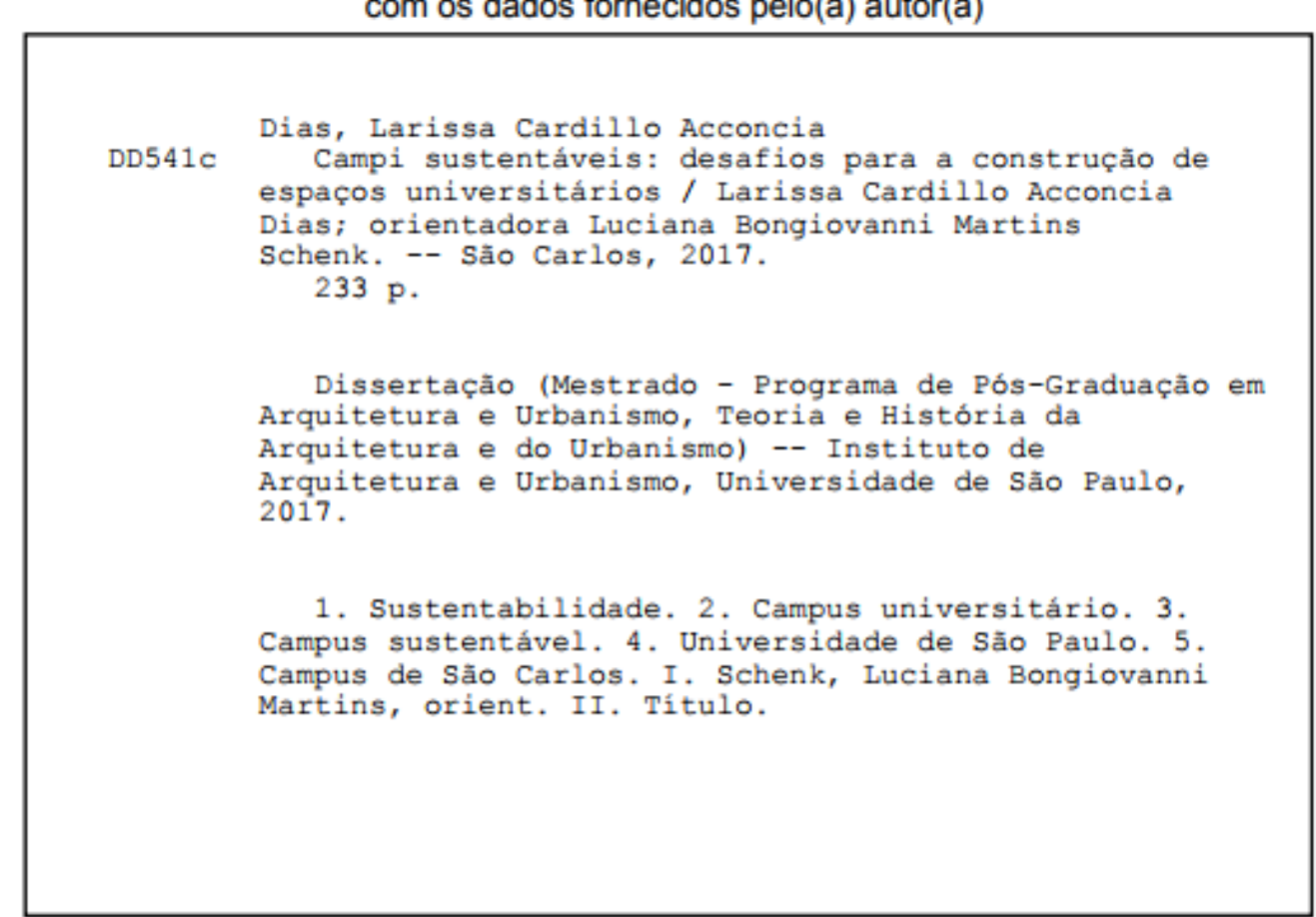




\section{FOLHA DE JULGAMENTO}

\section{Candidato(a): Larissa Cardillo Acconcia Dias}

Título da dissertação: "Campi Sustentáveis: desafios para a construçāo de espaços universitários"

Data da defesa: 19/05/2017

Orientador: Profa. Dra. Luciana Bongiovanni Martins Schenk

\section{Comissão Julgadora:}

Resultado:

Profa. Dra. Luciana Bongiovanni Martins Schenk

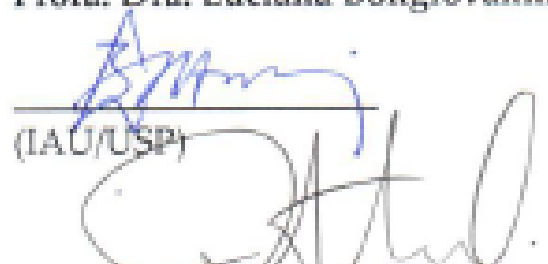

Prof. Dr. Rentoto Luiz Sobral Anelli

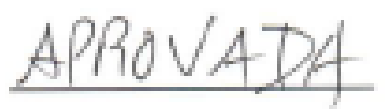
(IAU/USP)

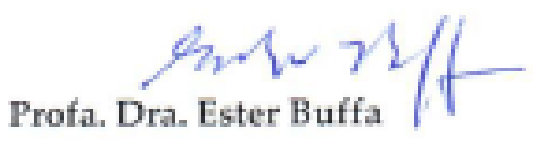

(UFSCar)

Prof. Dr. Glaucade Pauta Cocozza

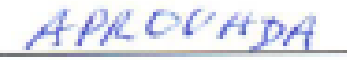

(FAUeD/UFU)

Coordenadora e Presidente da Comissão de Pós-Graduação do Programa de PósGraduação em Arquitetura e Urbanismo: Profa. Dra. Cibele Saliba Rizek. 

Aos meus avós, Aparecida e Natal Cardillo. 



\section{AGRADECIMENTOS}

Aos meus avós maternos que foram tão presentes e que me ensinaram, na prática, sobre as diferentes dimensões que a sustentabilidade possui, sem sequer saberem da existência ou da complexidade do termo. Sou imensamente grata por todos os ensinamentos de vida e de moral que me despertaram a vontade de melhorar o mundo e ajudar ao próximo; obrigada pela jornada que me trouxe até aqui.

Aos meus pais, Aparecida e Benedito, que tanto me incentivaram e apoiaram nessa caminhada. Obrigada pela compreensão, preocupação e carinho.

Em especial, também, à minha primeira e melhor amiga, Rebecca, que consegue deixar meus dias mais leves.

Ao Maurício, por acreditar em mim, apoiar-me e por compartilhar da ânsia de querer sempre aprender mais; por dividir comigo reflexões e conclusões sobre todo e qualquer assunto.

Ao Felipe, pela amizade e conversas tão animadas e curiosas.

Ao Cava e à Pati que pela amizade e confiança nos trouxeram o anjo Marco Anthonio, mais um incentivo para tornar o mundo um lugar melhor.

Gratidão também aos amigos que de uma forma ou outra estiveram presentes nessa caminhada: Camila, Mara, Michele, Monalisa, Nassara, Raphael e, especialmente, ao Daniel. Também aos novos amigos e irmãos que a fé me trouxe e que me ajudam de distintas maneiras. dr. Rafael.
Um agradecimento especial ao querido amigo, Gelson de Almeida Pinto, por toda a rica contribuição durante o período em que me orientou e pela amizade e apoio que continuam desde então.

À minha orientadora, Luciana Schenk, pelo auxílio e apoio nos momentos precisos, também por sua grande paciência e carinho. Por tudo, sou muito grata.

Agradeço, também, ao Instituto de Arquitetura e Urbanismo, aos professores e aos funcionários da graduação e da pós-graduação, e também aos pesquisadores e docentes do grupo URBIS por completarem minha formação profissional, por incentivarem meu crescimento intelectual e por aumentarem minha paixão pela pesquisa em distintas áreas dentro da Arquitetura e do Urbanismo.

Aos professores, de distintos níveis de ensino, que formaram quem sou hoje. Um agradecimento especial aos professores Marcel Fantin e Luciana Schenk pela confiança no estágio PAE e que contribuíram muito para minha pesquisa.

Obrigada aos amigos do IAU, em especial ao Victor pela ajuda desde o processo seletivo, ao Valmir e a Natália, amigos de mestrado que, juntos, caminhamos desde a PUC.

À professora Ester Buffa por todas as considerações e observações durante o exame de qualificação.

À CAPES, pelo apoio financeiro que permitiram a concretização de minha pesquisa.

À FATECE pela oportunidade.

Finalmente, agradeço à toda presença espiritual que me protegeu e me guiou pelos caminhos até aqui. 

"Minha pesquisa é como meu sentimento, dirigida para o que é o principal valor da vida: a poesia. A poesia está no coração do homem e é a capacidade de ir em direção à riqueza da natureza".

\author{
Le Corbusier
}





\section{RESUMO}

DIAS, L. C. A. Campi sustentáveis: desafios para a construção de espaços universitários. 2017. 233 f. Dissertação (Mestrado em Arquitetura e Urbanismo) - Instituto de Arquitetura e Urbanismo, Universidade de São Paulo, São Carlos, 2017.

Esta pesquisa trata do estudo dos campi universitários que adotaram posturas e diretrizes socioambientais para a promoção de espaços que sejam realmente sustentáveis a partir de suas estruturas organizacionais, de seus planejamentos institucionais, de suas gestões operacionais e da promoção da formação voltada para os princípios sustentáveis. A partir dessa apresentação, é estudado o campus 2 da Universidade de São Paulo, campus São Carlos, que passou por distintas tentativas, planejamentos e discussões através das mãos de diferentes profissionais, ao longo dos anos, que almejavam transformar esse território universitário em um que pudesse ser considerado sustentável. Para construir essa compreensão do objeto a ser estudado o trabalho apresenta um histórico do desenvolvimento das universidades e de seus territórios, o desmembramento do termo 'sustentabilidade' desde sua contextualização temporal até sua aplicação dentro do campo da arquitetura e do urbanismo, seguido pela parte do campus sustentável, desde diretrizes e modelos até processos de avaliação e, por fim, as iniciativas sustentáveis em campi universitários pelo mundo. Através do estudo apresentado é possível compreender de forma ampla e completa os processos pelos quais o campus 2 de São Carlos vem passando.

Palavras-chave: 1. Sustentabilidade; 2. Campus Universitário; 3. Campus Sustentável; 4. Universidade de São Paulo; 5. Campus de São Carlos.
DIAS, L. C. A. Sustainable Campi: challenges for building university spaces. 2017. 233 p. Dissertation (Master in Architecture and Urban Planning) Institute of Architecture and Urbanism, University of Sao Paulo, São Carlos, 2017.

This research work presents the study of university campi that adopted socioenvironmental positions and guidelines for the promotion of spaces that are truly sustainable. These guidelines are originated from their organizational structures, institutional planning, operational management, and the promotion of staff training focused on sustainable principles. Based on this research, an analysis of University of São Paulo's second campus in São Carlos, has been proposed, which has undergone different attempts, planning and discussions through the hands of different professionals over the years, that aimed to transform this university territory into one that could be considered sustainable. To fully comprehend the processes that are directly affecting the second campus of USP-São Carlos this work presents a study of universities' history followed by a deep analysis of 'sustainability' as a term since it's temporal contextualization to the use in architecture and urbanism field. After that the sustainable campus is presented with guidelines, models and evaluation processes followed by examples of sustainable initiatives in univesity campi throughout the world.

Keywords: 1. Sustainability; 2. Campus; 3. Sustainable Campus; 4. University of São Paulo; 5. São Carlos's Campus. 



\section{LISTA DE ILUSTRAÇÕES}

Figura 1- Fotografia do reservatório de água para a capital paulista, o Cantareira, praticamente seco, 2014, fotografia de Patrícia Stavis.

Figura 2- Esquema de crescimento sustentável elaborado pelo World Resources Institute, em 2002, apresentando a tridimensionalidade da sustentabilidade. Na parte superior está indicada a sustentabilidade econômica, na inferior, ao lado esquerdo, está a social e, a direita, a ambiental.

Figura 3- Ilustração de metalúrgica alemã em 1841, sem autor. .48

Figura 4- Padrões de crescimento apontados por Sachs (2008, p. 36) que atendem ao mesmo tempo as questões sociais, ecológicas e econômicas, dentro dos três pilares do desenvolvimento sustentável..

Figura 5- Fotografia mostrando a demolição entre a rua de l'Échelle e Saint Augustin para as reformas urbanas realizadas em Paris, 1877, fotografia de

Charles

Marville.

. .59

Figura 6- Montagem com imagens da cidade jardim. A direita há a planta esquemática onde o centro é composto por serviços coletivos e áreas verdes aumentando a eficiência energética da cidade; a direita há a maquete eletrônica representando teoricamente as ideias de Sir

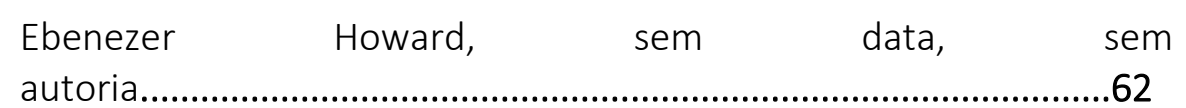

Figura 7- Maquete da Broadacre City cujos conceitos são meio ambiente, desenvolvimento sustentável e ecologia social, sem data...

Figura 8- Esquema da Estruturação Urbana Ecológica, Eckart Hahn, Berlim, 1984.

Figura 9- Mapa Jardim América feito pela City of São Paulo Improvements and Freehold Land Ltd., sem

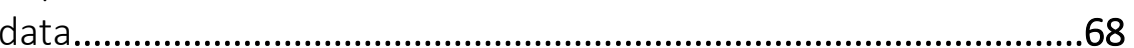

Figura 10-Edifício do Centro Médico Universitário da Universidade do Estado do Arizonas, EUA, tem a certificação LEED Platina, 2012, projeto de Lake|Flato Architects and

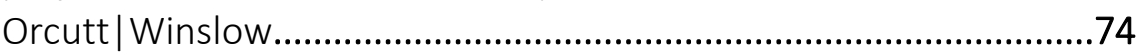

Figura 11- A Academia de Platão, mosaico localizado em Pompéia. 78

Figura 12- Universidade Al-Azhar, no Egito, fundada entre 970 e 972 a. C. É considerada a segunda universidade mais antiga do mundo que ainda está em funcionamento.

Figura 13- Localização das universidades em


Figura

XIII.

Figura 15- Representação da Escola Médica de Salerno, século $\mathrm{XI}$.

Figura 16- 'Studio Público em Bolonha', Universidade de Bolonha, sem data.

Figura 17- Universidade de Coimbra, sem data

Figura 18- A universidade Humboldt, em Berlim, e, a direita, a estátua de Alexander von Humboldt, sem data.

Figura 19- Dartmouth College, sem data

Figura 20- Fotografia do prédio da Escola Nacional de Belas-Artes, integrante da Universidade do Brasil, na Avenida Central em 1910

Figura 21- O Edifício Paula Souza, projetado por Ramos de Azevedo e que funcionou entre os anos de 1889- 1940, foi o primeiro prédio projetado para a Escola Politécnica, sem data

106

Figura 22- Mosteiro S. Gall que originou os da Ordem Carolíngia, sem data.

Figura 23- Mosteiro do Santa Croce, Florença, da Ordem Mendicante, sem data.....

Figura 24- Palazzo dell'Archiginnasio, Universidade de Bolonha, sem data.....
Figura 25- Planta histórica do desenvolvimento do Trinity College Cambridge, 1897

Figura 26- Vista do quadrangle, Universidade de Oxford, sem data

Figura 27- Vista aérea da Universidade de Oxford, sem data..... 117

Figura 28- O prédio da Bauhaus, Dessau, sem data.

Figura 29- Primeiros projetos de Colleges estadunidenses (Harvard, William and Mary, Princeton e Yale) 121

Figura 30- Universidade da Carolina do Sul, 1872 121

Figura 31- Ilustração da cidade de Cambridge, EUA. No primeiro plano estão os edifícios da Universidade de Harvard, 1668. .121

Figura 32- Plano de New Haver em Connecticut. O primeiro College de Yale do lado superior esquerdo, 1748. 122

Figura 33- Nassau Hall, Universidade de Princeton, 1760. 122

Figura 34- Esquerda: Campus de Berkeley, sem data. Direita: Plano diretor da Standford University, projeto de Olmsted e Coolidge, 1888. .123

Figura 35- Vista do Campus de Virgínia, sem data 124

Figura 36- Rotunda, Campus de Virgínia, sem data. 125

Figura 37- Vista aérea do campus de Virgínia, sem data. 126

Figura 38- Mapa atual do campus de Virgínia, sem data 126 
Figura 39- O primeiro estudo realizado para o IIT, sem data.

Figura 40- Projeto final do campus, sem data

Figura 41- Planta do campus com as obras de Mies Van der Rohe em destaque, sem data.

Figura 42- Crown Hall de 1955, IIT, sem data.

Figura 43- Projeto das unidades estudantis projetado por Alexander para a Universidade de Oregon, esse projeto visava a aumentar o senso de comunidade do campus, sem data.

Figura 44- Vista do campus de Oregon onde é possível observar, em especial, o Promenade, sem data.

Figura 45- Mapa do campus da Universidade de Oregon antes do planejamento de C. Alexander, 1969.

Figura 46- Mapa do campus da Universidade de Oregon após o planejamento de C. Alexander, 1975.

Figura 47- Planta da futura Cidade Universitária, Praia Vermelha, 1935.

Figura 48- Projeto de Le Corbusier para a Cidade Universitária da Universidade do Brasil, 1936.

Figura 49- Projeto de Lucio Costa e equipe para a Cidade Universitária da Universidade do Brasil, 1936. 136

Figura 50- Comparação entre os projetos de Piacentini, Le Corbusier e Lucio Costa e equipe, respectivamente.
Figura 51- Vista e planta da Universidade Federal do Rio de Janeiro, sem data.....

Figura 52- Projeto para a Cidade Universitária, 1945. 141

Figura 53- Projeto vencedor para a Cidade Universitária, sem data.

Figura 54- Planta da atual Cidade Universitária, sem data.

Figura 55- Vista aérea da atual Cidade Universitária, sem data.......

Figura 56- Implantação da UnB proposta por Lucio Costa, sem data...

Figura 57- Projeto de Oscar Niemeyer e equipe para o Instituto Central de Ciências, sem data.

Figura 58- Construção do campus da UnB ainda sem os prédios da Biblioteca, Restaurante Universitário e Reitoria, sem data. 146

Figura 59- Vista do campus da UnB, sem data. .146

Figura 60- Instituto Central de Ciências, o "Minhocão" de Niemeyer, 1962.

Figura 61- A Praça Maior da UnB, 1962

Figura 62- Organograma estrutural adaptado da Universidade Federal do Rio Grande do Sul.

Figura 63- Parte da Universidade de Alcalá 160 
Figura 64- Estudantes descansando em áreas de estar da Universidade de Tecnologia Chalmers. 160

Figura 65- Síntese das diretrizes apresentadas no capítulo 169

Figura 66- Categorias avaliadas pelo BRREEAM: Energia, Saúde e BemEstar, Inovação, Uso do Terreno, Materiais, Administração, Poluição, Transporte, Desperdício e Água.

Figura 67- As tipologias de certificação aplicadas pelo Green Building Council Brasil.

Figura 68- Os critérios e indicadores de sustentabilidade em campi avaliados pelo Greenmetric World University Ranking: Infraestrutura, Energia e Mudanças Climáticas, Desperdício, Água, Transporte e Educação

Figura 69- Padrões sustentáveis aplicados na Universidade de Sonora. 182

Figura 70- Vista aérea da UFLA, 2012. .185

Figura 71- APP e rio dentro do campus da UFLA, 2016. .186

Figura 72- O campus da UFLA, 2016 186

Figura 73- Organização hierárquica de gestão programa USP Recicla. 187

Figura 74- Campos de atuação EESC Sustentável .188

Figura 75- Uma das propostas apresentadas foi o projeto de uma cobertura viva para o edifício 1 da Faculdade de Direito da USP.....190
Figura 76- Integração entre as escalas edifício- quadra- Campus.....191

Figura 77- Vista aérea do campus 1 da USP São Carlos mostrando sua alta densidade e limite com a cidade.

Figura 78- Mapa do uso e ocupação do solo da microbacia do Córrego Mineirinho, São Carlos, 2011

194

Figura 79- Os Campus 1 e 2 da USP São Carlos inseridos na malha urbana....... 194

Figura 80- Projeto de urbanismo criado pela equipe do professor $\mathrm{dr}$. Carlos R. M. de Andrade para o campus 2 da USP São Carlos.

Figura 81- Vista aérea do campus 2 da USP São Carlos

Figura 82- Exemplo de ocupação do grid virtual do campus II da USP.

Figura 83- Membros do Grupo de Estudos e Intervenções Socioambientais trabalhando para a implantação de um Sistema Agroflorestal na área de mata ciliar dentro do Campus 2 da USP, sem data 


\section{LISTA DE TABELAS}

Tabela 1- Mudanças de paradigmas em relação ao homem e a natureza e seu ponto de equilíbrio.

Tabela 2- Cronologia das universidades na Europa

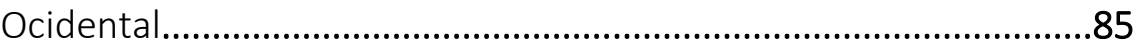

Tabela 3- Cronologia das primeiras universidades fundadas na América Latina

Tabela 4- Sinais iniciais apresentados pela ONU às universidades sustentáveis (1972- 1992).

155

Tabela 5- Proposta de organização institucional para a promoção da sustentabilidade em um campus.

Tabela 6- diretrizes para a concretização do compromisso institucional 159

Tabela 7- diretrizes para o planejamento físico de um campus sustentável.. 161

Tabela 8- diretrizes para o planejamento físico de um campus sustentável....... 

ABNT

APP

AQUA

BREEAM

CAPES

CIA CITY

CIAM

CMMAD

CNPq

$\mathrm{CO} 2$

COESF
Associação Brasileira de Normas

Técnicas

Área de Preservação Permanente

Alta Qualidade Ambiental

Building Research Establishment Environmental Assessment Method

Coordenação de Aperfeiçoamento de Pessoal de Nível Superior

City of São Paulo Improvements and Freehold Land Company

Congrès Internationaux d'Architecture Moderne

Comissão Mundial para o Meio ambiente e o Desenvolvimento

Conselho Nacional de Desenvolvimento Científico e Tecnológico

Gás Carbônico

Coordenadoria do Espaço Físico
COCESP

COPERNICUS

CUASO

ECO 92

EESC

EUA

FAHOR

FAPESP

FUNDUSP

HQE

IAU
Coordenadoria do Campus da Capital

Cooperation Program for Environmental Research in Nature and Industry through Coordinated University Studie

Cidade Universitária Armando de Salles Oliveira

Conferência das Nações Unidas sobre o Meio Ambiente e o Desenvolvimento

Escola de Engenharia de São Carlos

Estados Unidos da América

Faculdade Horizontina

Fundação de Amparo à Pesquisa do Estado de São Paulo

Fundo para a Construção da Cidade Universitária

Haute Qualité Environnementale

Instituto de Arquitetura e Urbanismo 
ONG

ONU

PML

PNUMA
Instituição de Ensino Superior

Illinois Institute of Technology

International Organization for Standardization

Lei de Diretrizes e Bases

Light Emitting Diode

Leadership in Energy and Environmetal Design

Massachusetts Institute of Technology

Norma Brasileira

Organization for Economic CoOperation and Development

\section{Organização Não Governamental}

Organização das Nações Unidas

Produção Mais Limpa

Programa das Nações Unidas para o Meio Ambiente
ProPESC

SGA

TBL

UFRJ

UFSCAR

UnB

UNCED

UNICAMP

USP

UTFPR

VOC

WIPIS
Programa de Pesquisa e

Experimentação para

Sustentabilidade no Campus

Superintendência de Gestão Ambienta

Triple Botton Line

Universidade Federal do Rio de Janeiro

Universidade Federal de São Carlos

Universidade de Brasília

Comissão Mundial sobre o Meio Ambiente e Desenvolvimento

Universidade Estadual de Campinas

Universidade de São Paulo

Universidade Tecnológica Federal do Paraná

Compostos Orgânicos Voláteis

Workshop Interdisciplinar de Pesquisa em Indicadores de Sustentabilidade 
1. INTRODUÇÃO.

1.1. Considerações Iniciais

1.2. Universidades, Territórios Universitários, Cidades

Universitárias e Campi. .26

1.3. Campi Sustentáveis .29

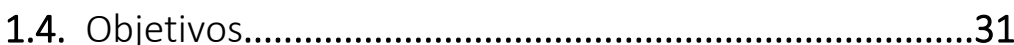

1.5. Justificativa e Metodologia............................................31

1.6. Estrutura do Trabalho.

2. SUSTENTABILIDADE .35

2.1. Definições e o desenvolvimento do conceito . .41 2.2. O sistema capitalista e o desenvolvimento (in) sustentável.

2.3. A transição atual do mundo insustentável para uma nova civilização: as mudanças de paradigmas em relação ao homem e à natureza.

2.4. Cidades Modernas, Cidades Insalubres: renovações urbanas e urbanismo sustentável. . .55

2.5. Arquitetura e Urbanismo Sustentáveis: importâncias e aplicações.

\section{HISTÓRIA DAS UNIVERSIDADES: ORIGENS E}

DESENVOLVIMENTO

3.1. O início: o modelo clássico e o domínio islâmico...........77

3.2. Do medievo à expansão pela Europa.
3.3. A Renascença e a Revolução Industrial: novas demandas profissionais, novas instituições superiores

3.4. As universidades modernas e contemporâneas.............91

3.5. O ensino no Novo Mundo: a universidade na América Latina e nos Estados Unidos

3.6. Universidades no Brasil: um início tardio 101

\section{TERRITÓRIO UNIVERSITÁRIO: CAMPUS E CIDADE} UNIVERSITÁRIA

4.1. Dos mosteiros a Bauhaus.

4.2. A concepção de uma nova comunidade acadêmica: o desenvolvimento de Campi.

4.2.1. Jefferson e a Universidade de Virgínia: o modelo do planejamento de campus.

4.2.2. Illinois Institute of Technology: a continuação das ideias de Mies Van der Rohe e da Bauhaus......127 4.2.3. Christopher Alexander e a Universidade de Oregon: o campus como uma experiência de projeto participativo.

4.3. Cidades Universitárias brasileiras.

132

4.3.1. Universidade do Brasil: a Universidade Federal do Rio de Janeiro e as propostas de Le Corbusier...133 4.3.2. A Universidade de São Paulo e a Cidade Universitária 'Armando de Salles Oliveira'. 
4.3.3. A Universidade de Brasília: um novo modelo que une o espaço universitário e o modelo de ensino..143

\section{CAMPI E SUSTENTABILIDADE: INVESTIGAÇÃO E ESTUDO DE}

CASO 149

5.1. Diretrizes para a promoção da Sustentabilidade em um campus......

5.1.1. Compromisso Institucional

5.1.2. Planejamento Físico .159

5.1.3. Gestão Operacional da Instituição de Ensino

Superior...

162

5.1.4. Ensino para a Sustentabilidade.

5.2. Métodos de avaliação e compromissos para a criação de Campi Sustentáveis. 170

5.3. Exemplos de Campi Sustentáveis.................................177

5.4. Estudo de caso: o campus 2 da Universidade de São Paulo, campus São Carlos.

6. CONSIDERAÇÕES FINAIS

Anexo B. 


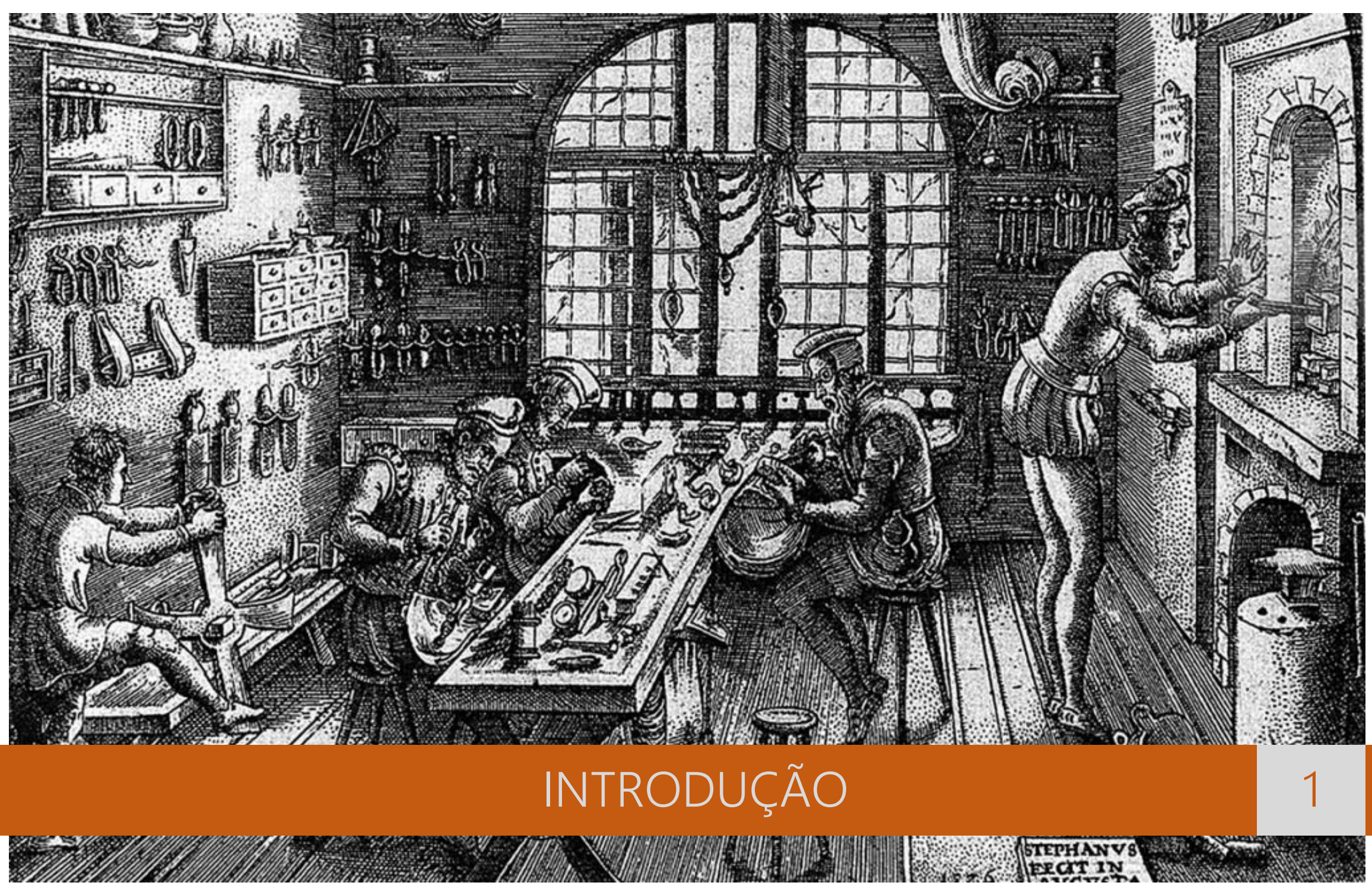


Ilustração do trabalho em uma corporação de ofícios.

Fonte da imagem: http://www.jurassico.com.br/aulas-de-historia/as-corporacoes-de-oficio/ (acessado dia 16 de junho de 2016, as 18:01 horas). 


\section{INTRODUÇÃO}

\subsection{Considerações Iniciais}

A sustentabilidade surgiu em minha vida acadêmica logo no primeiro ano da faculdade quando comecei a estudar o tema e pensei que nunca iria trabalhar com a sustentabilidade, além das próprias disciplinas. Semanas depois uma professora me chamou para participar de um grupo de pesquisa pois eu tinha "o perfil" e poderia contribuir para o trabalho em andamento. Era um grupo que estudava e aplicava conceitos da sustentabilidade em suas distintas vertentes. Inicialmente achei que seria algo temporário, mas com o tempo, a sustentabilidade tornou-se paixão, tema de pesquisas, projetos de extensão, tema de disciplina ministrada e dissertação.

O projeto de extensão, em especial, ocorreu nos últimos semestres de minha graduação e foi bastante marcante, a proposta era intervir numa escola que funcionava utilizando uma estrutura improvisada de uma antiga fábrica de sabão; o local recebia crianças e adolescentes dos 4 aos 14 anos e era um espaço potencialmente perigoso para elas.

Inicialmente iriamos realizar alguns projetos de conscientização como ensinar a separar seus lixos para reciclagem e reutilizar garrafas pets. Com o passar do tempo o projeto foi se desenvolvendo e começamos a realizar oficinas de confecção de adobes e pinturas dos muros com tinta de terra. Dávamos aulas sobre Educação Ambiental e Sustentabilidade e, no final, tínhamos todo um projeto para a reforma do espaço utilizando técnicas e materiais sustentáveis. A escola fechou por resolução municipal alguns meses depois.

Esse projeto me fez refletir sobre minha própria formação acadêmica, estávamos ensinando aqueles jovens sobre a sustentabilidade a partir de pesquisas que realizávamos, mas nós mesmos, futuros profissionais, tínhamos apenas uma disciplina que 
abordava de maneira bem superficial esse assunto na universidade: era óbvio que meus colegas, como futuros profissionais que deveriam se preocupar com o meio ambiente, estavam se formando com fragilidade nessa área. Eu ainda possuía um pouco mais de conscientização, mas ainda assim só compreendia a sustentabilidade nos aspectos ambientais e relacionados a materiais alternativos.

Esta ideia se expandiu e a curiosidade sobre a situação em outras universidades aumentou. Nas pesquisas iniciais para o projeto que foi apresentado no processo seletivo do mestrado pude constatar que, infelizmente, essa era a situação das faculdades de arquitetura e urbanismo. Em todas as faculdades analisadas, a sustentabilidade ainda é uma conceituação, ou área do conhecimento muito pouco ou quase nada abordada.

Inicialmente, essa dissertação focava o ensino de sustentabilidade nos cursos de arquitetura e urbanismo do Estado de São Paulo. Desenvolvendo o tema, foi observado que a questão do ensino era apenas uma preocupação dentre tantos questionamentos que foram surgindo no decorrer da pesquisa acerca de como a sustentabilidade deveria estar presente no cotidiano de alunos universitários, complementando suas formações acadêmicas em distintos aspectos além d o que é ensinado nas salas de aula e focar além do curso de arquitetura e urbanismo.

A investigação foi desenvolvendo uma nova abordagem de que a dissertação poderia ser mais ampla e complexa no sentido de pensar sobre a construção de campi sustentáveis e seus desafios, a partir da visão de uma profissional arquiteta e urbanista.

O desenvolvimento das universidades desde seu nascimento passou por grandes mudanças e adaptações. Esse processo é marcado por conflitos ideológicos e por experimentações em seus próprios espaços que acabaram por refletir na própria cidade e na universidade, seja em questões pedagógicas ou espaciais.

\subsection{Universidades, Territórios Universitários, Cidades Universitárias e Campi}

Para a compreensão do trabalho, antes de mais nada, é preciso compreender e distinguir a terminologia e conceitos dos termos universidades, territórios universitários, cidades universitárias e campus. 
Charle e Verger (1996) apresentam uma interessante definição do conceito de universidade como sendo uma comunidade, independente ou não, de docentes e discentes que se reúnem para o aprendizado de uma quantidade determinada de disciplinas de nível de ensino superior.

Universidades são comunidades cujos espaços são bastante complexos e cheios de especificidades traduzidos em seu porte, relação com a cidade que a cerca, permeabilidade urbana, diversidade e mudanças pedagógicas, áreas de ensino, no seu próprio espaço, em suas relações com seus alunos, funcionários e comunidade, na gestão e na modificação da paisagem, através da presença de laboratórios, bibliotecas, anfiteatros, espaços midiáticos, salas de aulas, entre outros espaços.

Godoi (2015, p. 07) contribui para a compreensão do termo 'universidade' como uma instituição que a partir de visões de distintos pesquisadores e planejadores: Gaines (1991) utiliza o termo campus apenas para espaços ocupados e planejados, ou seja, o termo está diretamente ligado à espacialidade. Já o autor Muthesius (2000) apresenta o temo campus como uma denominação surgida no fim do século XVIII na Universidade de Princeton que engloba a localização da instituição; o autor afirma que o termo campus foi utilizado tarde e de forma errônea, ou seja, associando campus como uma "universidade em um jardim"; o autor não distingue a universidade de seu local físico e utiliza do termo Cidade Universitária ao citar universidades como uma "instituição cultural nacional".

\section{Segundo o dicionário Michaelis ${ }^{1}$ território significa:}

“1. Grande extensão de terra; 2. Porção da superfície terrestre pertencente a um país, estado, município, distrito etc; 3. Região sob a jurisdição de uma autoridade; 4. Região um tanto populosa, mas sem habitantes em número suficiente para constituir um Estado, sendo pois administrada pela União; 5. Área da superfície de terra que contém uma nação, dentro de cujas fronteiras o Estado exerce a sua soberania, e que compreende todo o solo, inclusive rios, lagos, mares interiores, águas adjacentes, golfos, baías e portos".

Já 'Cidade Universitária', para Dober (1963), é uma região autônoma com suas próprias regras, diferente do campus que é dependente da infraestrutura urbana, assim, poucos podem ser exemplificados como cidades universitárias.

\footnotetext{
${ }^{1} \mathrm{http} / / /$ michaelis.uol.com.br/busca?id=vkZvR (acessado dia 30 de agosto de 2016, as 15:55 horas).
} 
O termo 'território universitário', quando utilizado, é compreendido como um espaço geográfico inserido em um "mundo globalizado contemporâneo" (Godoi, 2015, p. 10).

É preciso compreender o espaço físico de uma instituição de ensino superior como um local onde acontecem as atividades acadêmicas, como o local de aprendizado e como local de identidade institucional. $O$ espaço onde ocorre o ensino superior é caracterizado pelo próprio modelo pedagógico, ou seja, o território apresenta em suas construções a trajetória de ensino da instituição e é sua própria identidade.

Segundo Godoi (2015) as primeiras cidades universitárias brasileiras nasceram no início do século XX a partir de modelos europeus da beaux-arts, de Agache para a Universidade do Brasil, ou de modelos baseados a partir da art-déco de Piacentini, ou de modelos modernistas de Le Corbusier. Independentemente de sua origem, esses espaços podem ser considerados cidades universitárias a partir de definições de Muthesius.

Para Carlos Andrade (in Pinto e Buffa, 2009) a proposta desses planejadores era a construção de uma universidade vinculada ao meio urbano sem seguir o modelo de campus americano, afastado das cidades. O autor ainda escreve sobre como os campus e cidades universitárias no Brasil foram um local experimental para o urbanismo, a arquitetura e o paisagismo modernos.

Turner (1995) define campus citando o termo 'academical village', utilizado por Jefferson, como origem do planejamento de campus universitário; o termo campus remete à concepção de Colleges e universidades como comunidades ou pequenas cidades.

Dober (1963) utiliza do termo 'campus' para se referir ao território universitário, independentemente da localização, de quando foi construído ou planejado, ou se é uma university ou College. O autor define o termo como construções agregadas a espaços verdes.

O campus ou Cidade Universitária é um modelo específico de território localizado em:

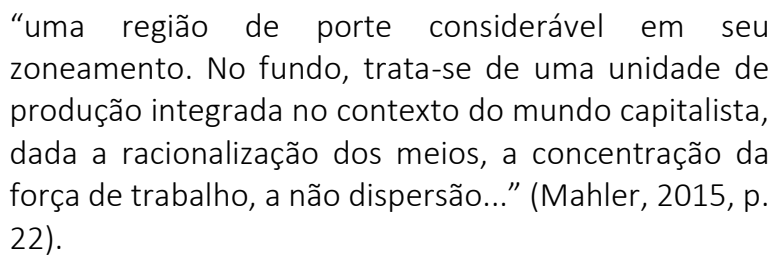
zoneamento. No fundo, trata-se de uma unidade de produção integrada no contexto do mundo capitalista, dada a racionalização dos meios, a concentração da força de trabalho, a não dispersão..." (Mahler, 2015, p. 22).

Os planejamentos europeus, norte-americanos e latinoamericanos são distintos e importantes contribuintes para a história das universidades apresentando peculiaridades em seus valores 
ideológicos, simbólicos, culturais, acadêmicos, comunitários e científicos. No Brasil, as universidades nasceram tardias e sofreram longos períodos burocráticos, políticos e de crises financeiras. Outro problema foi que foram criadas como meros locais para a reprodução isolada de conhecimentos. Apesar de todo o histórico brasileiro, os modelos de cidades universitárias são pioneiros no que diz respeito às questões de planejamento e projeto.

\subsection{Campi Sustentáveis}

Sachs (2008) discute conceitos sobre sustentabilidade, incluindo as políticas econômicas, sociais, ambientais, culturais, territoriais, nacionais e internacionais. O autor também mostra a relação entre estes conceitos e, sendo importante tratar o assunto de forma indissociável, pensando de forma multi-dimensional.

A preocupação com a questão ambiental nos últimos anos vem também envolvendo a preocupação na e com a universidade em nosso país e no mundo, seja em seus espaços físicos e estruturais, campus, seja em ações administrativas, políticas internas, ou com a participação de alunos e da própria universidade.

As universidades, atualmente, estão ampliando consideravelmente a quantidade de matrículas na graduação e na pós-graduação e, para suportar esse crescimento, é preciso ampliar suas estruturas físicas com novos edifícios, com novas redes de infraestruturas ou até mesmo com novos campi. Assim, é preciso conciliar seus crescimentos com as dimensões sustentáveis, além da implantação de medidas efetivas de comprometimento da instituição com a sustentabilidade.

Uma universidade deve ser responsável pelas questões do desenvolvimento sustentável pois é um espaço que difunde conhecimentos e forma profissionais que irão atuar na sociedade.

É importante compreender as universidades como pequenas cidades e que como tais necessitam de redes de infraestruturas como coleta e distribuição de água e oferecimento de energia elétrica (Tauchen e Brandli, 2006, p. 505)².

bastante preocupante e que escancara a urgente necessidade das universidades reverem suas posições em relação ao meio ambiente.

\footnotetext{
Segundo Bonett et al. (2002), o consumo per capita de água no campus de uma universidade próxima a Bordeaux, França, é maior do que a média urbana, fator
} 
Uma universidade sustentável deve levar em conta os conceitos apresentados por Sachs unindo as dimensões do ensino, pesquisa, extensão, administração e gestão da universidade e vivências sustentáveis no próprio espaço universitário que por sua vez guardaria também perspectivas relacionadas à sustentabilidade em sua constituição física. Segundo Velazquez et al. (2006, p. 811), a definição de uma universidade sustentável é:

"Uma instituição de ensino superior, como um todo ou em parte, que busque a promoção, a nível regional ou global, da minimização de impactos negativos ambientais, sociais, econômicos e à saúde gerados pelo uso dos seus recursos quando do cumprimento de suas funções de ensino, pesquisa, extensão e manutenção de forma a ajudar a sociedade a fazer a transição para estilos de vida sustentáveis".

Vários autores analisam os processos de transição das universidades em universidades sustentáveis, indicando e ponderando aspectos que facilitam e que dificultam esse processo de mudanças dentro da universidade; dentre os fatores que dificultariam a implementação e a institucionalização da sustentabilidade nas universidades são destacados por pesquisadores da área: (a) as resistências às mudanças e à inovação; (b) as barreiras enfrentadas dentro das próprias instituições; e (c) a limitação da compreensão do conceito de sustentabilidade por parte dos gestores.

Apesar desses fatores, há os aspectos que promovem a implementação da sustentabilidade nas universidades segundo outros pesquisadores da área: (a) a formalização do compromisso da instituição com a sustentabilidade (Lozano et al., 2014); (b) a preocupação dos gestores e líderes com o tema; (c) o estabelecimento de uma forma consistente de avaliar o desempenho institucional em relação à sustentabilidade (Amaral et al., 2015); (d) a participação dos professores e funcionários; (e) e a inclusão da sustentabilidade nos currículos.

O território de uma universidade tem uma grande probabilidade de passar por distintos tipos de experimentações resultando em novas espacialidades e relações. Por esse ponto de vista é necessário que as propostas elaboradas busquem a plena abordagem das questões ambientais e sociais. 


\subsection{Objetivos}

O objetivo geral deste trabalho é estudar as possíveis relações entre a sustentabilidade e os campi universitários.

Os objetivos específicos deste trabalho são:

1. Apresentar o histórico do início e desenvolvimento das principais universidades e campus;

2. Apresentar os modelos de planejamento de campus, sobretudo no país;

3. Apresentar os conceitos e teorias sobre a temática da sustentabilidade;

4. Apresentar os principais campi sustentáveis e suas experiências;

5. Apresentar os fatores que fazem com que um campus possa ser considerado sustentável;

6. Desenvolver uma reflexão crítica acerca de pontos fundamentais para se pensar a sustentabilidade em campi universitários hoje;
7. Apresentar e analisar o desenvolvimento do Campus 2 da USP São Carlos em suas tentativas de tornar-se um modelo de campus sustentável.

\subsection{Justificativa e Metodologia}

A justificativa para a realização deste trabalho é a demanda por uma referência mais atualizada sobre o desenvolvimento de campus sustentável.

Após o término deste trabalho será possível identificar os principais fatores que caracterizam um campus sustentável e, a partir da documentação e análise das tentativas do campus 2, possibilitar que outra universidade que almeje adaptar ou iniciar um campus sustentável possa utilizar essa pesquisa como um parâmetro inicial de seus projetos.

Os primeiros capítulos são um levantamento bibliográfico do tema a partir das visões de diferentes e importantes autores que tratam do tema; o estudo de caso, importante questão do trabalho, por ser uma situação que ainda está em curso e que se arrasta por anos, é relatado como uma apresentação do que já ocorreu até então 
a partir do levantamento de documentos, entrevistas e outros tipos de materiais coletados. Pelo fato de ser uma situação que ainda está ocorrendo e que está sendo afetada pela situação da crise financeira nas universidades públicas, é proposto para a elaboração de um trabalho futuro o relato e documentação do campus que será finalizado.

\subsection{Estrutura do Trabalho}

Para que fosse possível alcançar os objetivos deste trabalho, os capítulos foram divididos da seguinte maneira:

O primeiro capítulo da dissertação apresenta de maneira resumida e introdutória os elementos relacionados diretamente com a pesquisa como diferenciações semânticas dos termos Universidades, Territórios Universitários, Cidades Universitárias e Campi, a importância de campi sustentáveis, os objetivos, a justificativa e metodologia do trabalho e a estrutura da pesquisa.

Como base para o entendimento da análise posterior, o segundo capítulo aborda a sustentabilidade de forma a apresentar seu histórico, seus principais conceitos e definições, e como o tema se enquadra na situação atual política econômica e social; em seguida o tema do urbanismo sustentável é apresentado e como as questões envolvidas no assunto podem modificar o espaço urbano. Por fim, o encerramento do capítulo discute a importância do tema da sustentabilidade para a arquitetura e urbanismo.

Após apresentar a sustentabilidade de forma a proporcionar ao leitor a base necessária para entendimento da análise proposta no trabalho, o próximo tema abordado é a história das universidades. A história da criação das universidades e seu desenvolvimento até o modelo chegar ao Brasil e ser adaptado para as necessidades e realidades locais, além dos métodos de ensino adotados durante o tempo.

Para entender como um campus universitário se torna sustentável, ou mesmo é planejado como um campus sustentável, uma análise de como o espaço físico universitário foi criado e modificado ao longo do tempo é apresentada. Através de exemplos de importantes universidades que influenciaram direta ou indiretamente o projeto dos campi no Brasil, o capítulo procura construir uma base de conhecimento sobre o território universitário. 
O capítulo 5 é a parte do texto na qual são apresentadas as diretrizes para a criação ou adaptação para um que um campus possa ser considerado sustentável; além das diretrizes, os próprios métodos de avaliação de campus sustentáveis são responsáveis por influenciar a maneira de como as universidades fazem seus planejamentos sustentáveis para seus campi. São também apresentadas as universidades consideradas mais sustentáveis de acordo com os modelos, diretrizes e métodos de avaliação considerados e a relação do sucateamento das universidades e a sustentabilidade.

O último capítulo também apresenta o estudo de caso deste trabalho: o campus 2 da Universidade de São Paulo, campus São Carlos. 


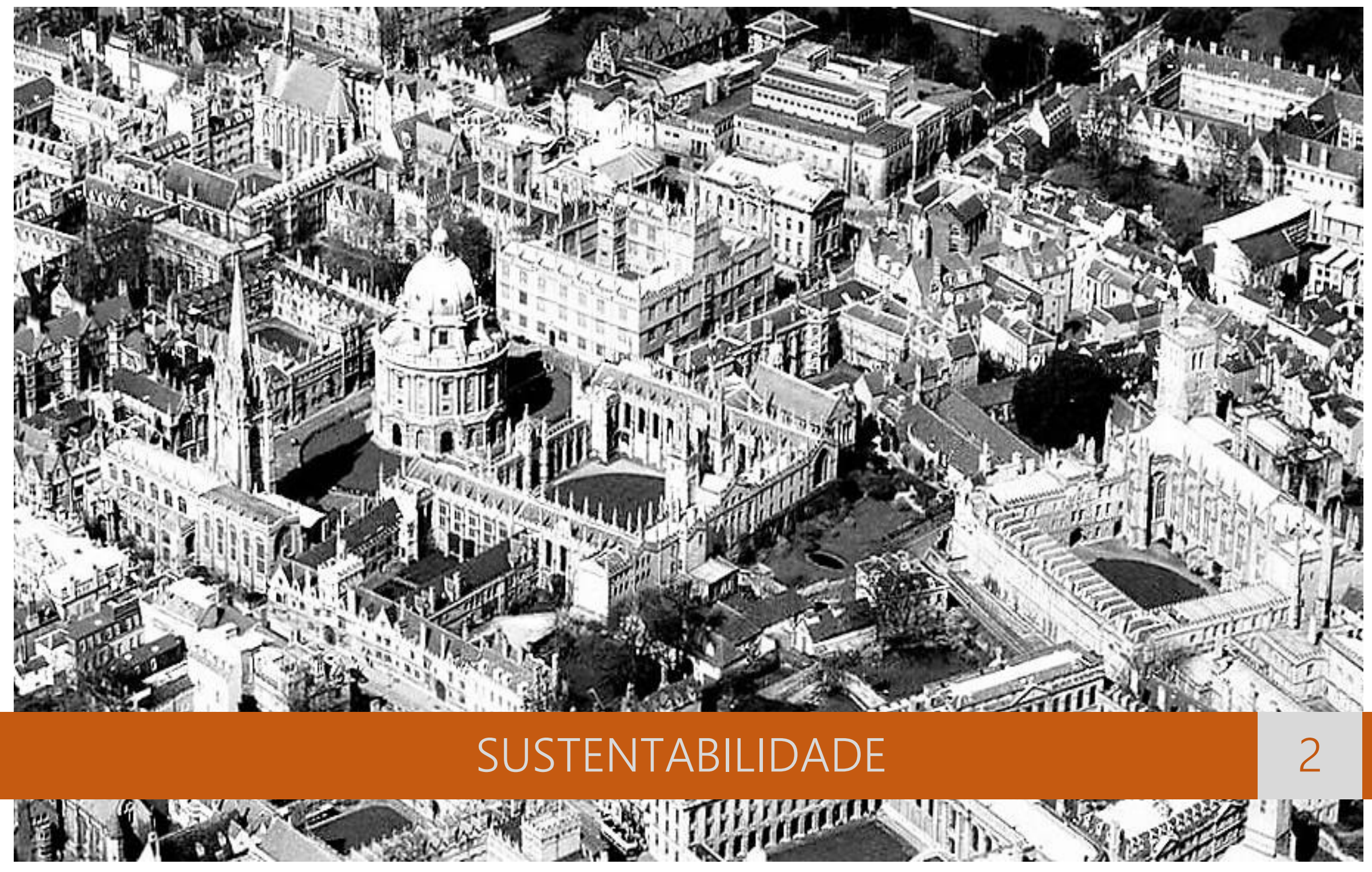


Universidade de Oxford, no Reino Unido, uma das mais antigas instituições de ensino da Europa Ocidental.

Fonte da imagem: https://www.ox.ac.uk/visitors/visiting-oxford?wssl=1 (acessado dia 19 de junho de 2016, as 21:44 horas). Editada pela autora. 


\section{SUSTENTABILIDADE}

O relacionamento do homem com a natureza se modificou intensa e radicalmente no decorrer da história: nos períodos da Idade Média e do Renascimento a cidade era um local para fugir da selvageria do campo e da natureza; já no período da Revolução Industrial, a natureza passou a ser idealizada como um paradigma clássico de oposição à natureza e à cidade, que era considerada um espaço insalubre e que acabou por contribuir com a criação de projetos de cidades utópicas e ideais relacionadas à natureza ${ }^{3}$.

Segundo Montaner (2012), no período da revolução industrial o entorno passou a ser modificado a partir de ações exploradoras, o que contribuiu para afastar a arquitetura de seu equilíbrio com a natureza; a despeito de somente no final do século XIX e início do século XX que as cidades da Europa e dos Estados Unidos passaram a contar com vias arborizadas.

"Se procurar as origens (...) da crise ambiental atuais, ter-se-á que procurar as causas e o período em que

\footnotetext{
${ }^{3}$ Profissionais teóricos ou práticos como Olmsted (1822-1903), Sitte (1843-1903), Howard (1850-1928) e F. L. Wright (1867-1959).
}

${ }^{4}$ http://www.unep.org/geo/ (acessado dia 26 de agosto de 2015, as 11:56 horas). começaram a se dissolver os antigos limites da cidade e as mudanças socioculturais que acompanharam essa dissolução. Embora o fato já demonstrasse seus sinais no período medieval, ele só se concretizou a partir do renascimento, vendo-se o auge dessa formalização no período barroco" (Franco, 2001, p. 19).

As ocorrências de catástrofes e anormalidades de fenômenos naturais intensos e extremos são sinais que testemunham alterações na Natureza Física do mundo que habitamos.

De 1997 a 2012 a Organização das Nações Unidas, ONU, apresentou relatórios chamados de Global Environmental Outlook ${ }^{4}$ que mostravam distintos cenários que o mundo poderia enfrentar em cerca de trinta anos. Alguns desses cenários são bastante pessimistas como: crescente falta de água, aquecimento global e poluição. Passados apenas sete anos esses cenários já parecem realidade para muitos países: segundo o jornal estadunidense Los Angeles Times ${ }^{5}$, o Estado norte americano da Califórnia está sofrendo com o clima mais

\footnotetext{
${ }^{5}$ http://inhabitat.com/can-nasa-solve-californias-devastating-drought-before-itstoo-late/ (acessado dia 26 de agosto de 2015, as 12:13 horas).
} 
seco desde 1895, resultando na drástica redução das águas subterrâneas e das bacias; no ano de 2014 havia documentos que mostravam que o Estado contava com cerca de dois anos de abastecimento de água, mas a seca estava diminuindo este prazo pela metade.

Al Gore, ambientalista e ex-vice-presidente dos Estados Unidos, apresenta um documentário em 2006 chamado 'Uma verdade inconveniente', An Inconvenient Truth, no qual mostra de maneira bastante realista o aquecimento global e suas consequências. O ambientalista enfatiza as catástrofes ambientais ocorridas no mundo como o derretimento de geleiras, as ondas de calor que ocorrem na Europa e os furacões Katrina, nos Estados Unidos, e o Catarina, no Brasil. Segundo Al Gore esses eventos serão cada vez mais frequentes e mais intensos. Apesar da apresentação destes cenários catastróficos, o objetivo do documentário é mostrar que é preciso e é possível que a população e seus governantes encontrem soluções.

6 http://planetasustentavel.abril.com.br/blog/planeta-urgente/milhares-deeuropeus-sofrerao-morte-prematura-por-

poluicao/?utm_source=redesabril_psustentavel\&utm_medium=facebook\&utm_c ampaign=redesabril psustentavel planetaurgente (acessado dia 26 de agosto de 2015, as 13:28 horas).
É previsto que cerca de 400 mil pessoas irão morrer prematuramente na Europa por falta de iniciativas mais efetivas para diminuir a poluição sonora e do ar. A Europa sofre com a perda da biodiversidade causada pela agricultura e pela urbanização, e com o estado precário de muitos sistemas de água doce ${ }^{6}$. Ainda sob uma visão pessimista sobre o destino europeu, James Lovelock (apud Mostafavi e Doherty, 2014) escreve 'A Vingança de Gaia', em 2006 afirmando que nas proximidades do ano de 2040 a Europa central, como Paris e Berlim, vai passar por um processo de desertificação, assim como ocorreu com o Saara, a Grã-Bretanha só irá escapar ilesa desse processo por sua localização oceânica.

O Brasil, em 2014 e 2015, também sofreu as consequências das mudanças climáticas. Um exemplo foi, no início de 2015, a maior cheia do rio Acre $^{7}$ que deixou 20 mil desabrigados; essa cheia foi provavelmente ampliada pelo desmatamento das margens do rio e da Amazônia.

7 http://noticias.uol.com.br/cotidiano/ultimas-noticias/2015/03/09/cheia-no-acfoi-grito-de-alerta-da-natureza-diz-viuva-de-chico-mendes.htm (acessado dia 26 de agosto de 2015, as 12:30 horas). 
Nesse período, outro importante exemplo foi vivenciado pelos Estados de Minas Gerais, do Rio de Janeiro e, sobretudo, de São Paulo, que atravessaram uma grande seca e crise hídrica jamais vistas ${ }^{8}$. O maior reservatório de água potável do Estado paulista contou com menos de $5 \%$ de sua capacidade, além da falta de água houve a iminência de apagões e cortes na luz. A cidade de São Paulo possuía para seu abastecimento apenas os volumes mortos dos reservatórios do Cantareira, os quais não possuem nenhuma garantia da qualidade de suas águas.

A notícia mais impactante foi dada em 13 agosto de 2015: a partir dessa data a população havia estourado o orçamento do Planeta Terra, ou seja, já nesse período os seres humanos haviam finalizado com "todos os recursos que a Terra é capaz de oferecer de forma sustentável no período de um ano"9.

"A diferença entre a capacidade de regeneração do planeta e o consumo humano gera um saldo ecológico negativo que vem se acumulando desde a década de 80, também estimulado pelo crescimento populacional (...). Vinte anos atrás, o 'Dia da Sobrecarga da Terra'

8 http://www.publico.pt/mundo/noticia/seca-historica-comprometeabastecimento-de-agua-e-luz-no-brasil-1684691 (acessado dia 26 de agosto de 2015, as 12:52 horas).

${ }^{9} \mathrm{http}$ //planetasustentavel.abril.com.br/noticias/hoje-humanidade-entra-chequeespecial-terra-895761.shtml (acessado dia 26 de agosto de 2015, as 13:33 horas). acontecia em 10 de outubro. Mas em 1975, era 28 de novembro. Hoje, é 13 de agosto. Se continuarmos no ritmo atual, prevê o estudo, vamos consumir o equivalente a dois planetas até 2030, antecipando ainda mais o 'Dia da Sobrecarga', para junho'. ${ }^{10}$

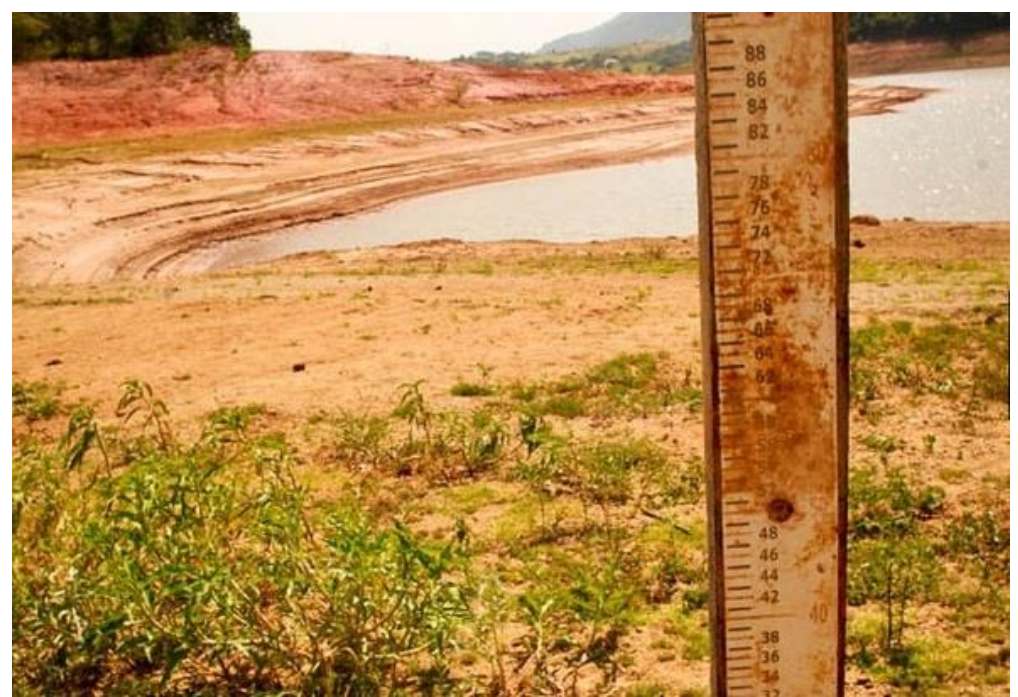

Figura 1- Fotografia do reservatório de água para a capital paulista, o Cantareira, praticamente seco, 2014, fotografia de Patrícia Stavis.

(Fonte: http://ultimosegundo.ig.com.br/brasil/2014-07-17/seca-docantareira-pode-levar-sp-a-depender-de-caminhoes-pipa-e-aguaengarrafada.html, acessado dia 26 de agosto de 2015, as 12:47 horas).

10 http://planetasustentavel.abril.com.br/noticias/hoje-humanidade-entracheque-especial-terra-895761.shtml (acessado dia 26 de agosto de 2015, as 13:33 horas). 
Alguns autores relacionam essas crises ambientais com o modelo econômico e com o sistema capitalista: James O'Connor (2002 apud Quintana e Hacon, 2011), por exemplo, acredita que a exploração ilimitada do trabalho e da natureza acaba deixando o próprio capitalismo em risco, enquanto Chesnais e Serfati (2003 apud Quintana e Hacon, 2011), afirmam que esse tipo de exploração é característico da própria economia capitalista.

Quanto mais o ser humano consome, mais aumenta sua dívida com o meio ambiente e os resultados são catastróficos: perda de bens naturais, desequilíbrio climático, redução de florestas, perda de biodiversidade, escassez de alimentos, redução da produtividade do solo e acúmulo de gás carbônico na atmosfera, este último é o responsável pelas mudanças climáticas.

Não é mais possível sustentar esse crescente déficit orçamentário com a natureza. É necessário rever os costumes do homem sob uma ótica sustentável e planejar suas ações dentro de seus conceitos se for desejado manter a vida no planeta, por isso é tão vital a vivência, propagação e ensinamentos da sustentabilidade que levem em conta inclusive os processos ideológicos desse amplo conceito. 


\subsection{Definições e o desenvolvimento do conceito}

Segundo Franco (2001), o termo sustentabilidade se origina do termo 'comportamento prudente', ou seja, o cuidado ao se utilizar de recurso para assegurar sua potencial renovação.

Ainda segundo Franco (2001), é importante usar somente o necessário para garantir que o meio ambiente possa se renovar.

O termo sustentabilidade é o equilíbrio entre todo o meio ambiente, compreendendo que toda a estrutura ambiental afeta e é afetada pelo ser humano que dela participa. A sustentabilidade, então, contempla as escolhas que o homem faz em relação às maneiras de produção, consumo, moradia, alimentação e transporte, levando sempre em conta os "valores éticos, solidários e democráticos"11.

Xavier, (2011, p. 36), aponta as opiniões de importantes pesquisadores a respeito do termo, como Sahtouris (2009) que afirma que é preciso compreender que não adotar posturas sustentáveis implica no fim da sobrevivência de futuras gerações; já Myttenaere
(2006) acha necessário traduzir o termo sustainable, sustentável, pelo adjetivo durable, durável, o que remete a um desenvolvimento durável sem questionar o desenvolvimento, pois, ao se falar em algo sustentável levanta mais questionamentos do que afirma esse desenvolvimento; Villela (2007) ressalta a necessidade de se traduzir - termo francês développement durable, ou seja, um desenvolvimento durável, que deve ser preservado para as presentes e futuras gerações.

O termo sustentabilidade, então, pode ser compreendido como uma possibilidade de manter não apenas a espécie humana, mas a totalidade do meio e seus participantes, numa vida segura, saudável e produtiva, vivendo em equilíbrio com a natureza e com os valores culturais.

Sahtouris (2009 apud Xavier, 2011) afirma que a sustentabilidade deve ir além das esferas ambientais físicas, estrito

\footnotetext{
${ }^{11}$ https://sustentabilidade.sescsp.org.br/conceito-de-sustentabilidade (acessado dia 21 de fevereiro de 2016, as 14:41 horas).
} 
senso, e incluir a compreensão do ser, a reflexão de como cada indivíduo pensa e age em relação ao outro e a si próprio.

Segundo Cunha e Guerra (2012), a primeira vez que surgiu a percepção em relação ao meio ambiente foi após a Segunda Guerra Mundial, quando o homem percebeu que a natureza é finita e que sua destruição também acarretaria na destruição do próprio ser humano.

O conceito de sustentabilidade desenvolve-se a partir da compreensão da crise e dos impactos ambientais gerados pela ação humana. As décadas de 60 e 70 foram marcadas por manifestações de cunho ambientalista e por preocupações em relação ao crescimento econômico e a degradação dos ecossistemas. Antes os impactos ambientais eram compreendidos como o resultado inevitável do avanço do capitalismo, mas, a partir deste período, cresce a preocupação e o interesse nas populações em criarem uma relação mais harmônica com o meio ambiente; diversos eventos que

12 O Clube de Roma elaborou, em 1972, um documento chamado 'Os Limites do Desenvolvimento' cujos principais objetivos eram discutir problemas como a necessidade de minimizar ou até parar com a exploração industrial dos recursos naturais (Cunha e Guerra, 2012).

${ }^{13}$ Segundo Fernando Almeida (2002 apud Schweigert, 2007, p. 74) “o Brasil foi um dos países que mais se empenhou na convocação da Conferência de Estocolmo porque vivenciava o apogeu de seu 'milagre econômico', propagado pelo regime reuniram líderes mundiais tentaram compreender suas ações sobre a natureza e as possibilidades de minimizarem seus impactos ambientais.

Em 1972, o Clube de Roma ${ }^{12}$ analisou o rápido crescimento populacional sobre os recursos naturais. O principal argumento era que vários fatores como a população mundial, a poluição, a industrialização e o esgotamento dos recursos naturais aumentavam exponencialmente, enquanto a disponibilidade dos recursos aumentava linearmente. As previsões feitas pelo Clube de Roma pareciam ser confirmadas pela crise do petróleo, em 1973, que levou ao mundo uma enorme crise financeira; segundo essas previsões, somente mudanças drásticas no estilo de vida, sobretudo para o aumento populacional em países mais pobres, poderiam evitar um colapso da civilização (Agopyan e John, 2011).

Também em 1972 ocorreu a Conferência de Estocolmo ${ }^{13}$, que tinha como objetivo conscientizar os países sobre o controle da

militar (...) o posicionamento do Brasil foi decisivo para promover uma revisão da questão dos limites do crescimento. A começar pela sua afirmação que, considerando a miséria como o mais grave efeito poluidor, só o desenvolvimento econômico e social pode reverter esse problema; por isso, argumenta em favor do direito de cada nação empregar seus recursos naturais para atingir tal desenvolvimento". 
poluição de rios, mares e ar. Esse foi o primeiro grande encontro internacional voltado para a discussão de problemas ambientais (Martins, 2010). A Conferência de Estocolmo ${ }^{14}$ reuniu representantes de 113 países e 250 ONGs que, a partir da compreensão da insustentabilidade na qual o planeta estava vivendo, recomendaram propostas para o desequilíbrio ecológico e a pobreza. Essa conferência resultou no documento chamado 'Declaração sobre o Ambiente Humano- Declaração de Estocolmo e Plano de Ação para o Meio Ambiente' (Rodrigues, 2002). Na Conferência de Estocolmo também foi criado o Programa das Nações Unidas para o Meio Ambiente, PNUMA, cujos principais objetivos são:

"Manter o estado do meio ambiente global sob contínuo monitoramento; alertar povos e nações sobre problemas e ameaças ao meio ambiente e recomendar medidas para melhorar a qualidade de vida da população sem comprometer os recursos e serviços ambientais das gerações futuras"15.

\footnotetext{
${ }^{14}$ Segundo Sachs (2008), nesta conferência tinham dois grupos opostos entre si: os que defendiam o crescimento como prioridade e que os danos poderiam ser revertidos posteriormente, e os que defendiam que se o crescimento não fosse parado imediatamente a população iria desaparecer em consequência da poluição e da escassez de recursos ambientais; as crenças dos dois grupos foram rejeitadas e substituídas pela ideia de que o crescimento econômico ainda deveria ocorrer porem de uma maneira em que a natureza fosse respeitada, ou seja, o meio ambiente poderia ser utilizado de forma racional e sustentável em benefício dos povos (Sachs, 2008, p. 55).
}

A proposta de ecodesenvolvimento ${ }^{16}$ surgiu das discussões da ECO 72 em Estocolmo, na Suécia. O conceito foi originalmente concebido por Maurice Strong e posteriormente desenvolvido, principalmente, por Ignacy Sachs ${ }^{17}$.

Sachs (1976) fala sobre os princípios do ecodesenvolvimento:

(a) Compensação das necessidades básicas; (b) Preocupação com as próximas gerações; (c) Participação popular; (d) Preservação e conservação dos recursos naturais e do meio ambiente; (e) Criação de um sistema que garanta emprego, segurança social e respeito a outras culturas; (f) Projetos educacionais.

Segundo Leff (2004 apud Schweigert, 2007), as teorias do ecodesenvolvimento foram enfraquecidas antes de suas propostas terem algum alcance mais crítico e transformador, era necessário que houvesse um desenvolvimento que conseguisse unir o

${ }^{15}$ https://nacoesunidas.org/agencia/pnuma/ (acessado dia 16 de maio de 2016, as 20:13 horas).

${ }^{16} \mathrm{O}$ ecodesenvolvimento surgiu para diminuir os impactos ambientais sem delimitar a qualidade de vida do ser humano e suas necessidades, para que isso pudesse ocorrer a tecnologia e a ciência foram os principais instrumentos (Gutberlet, 1998 apud Schweigert, 2007). O ecodesenvolvimento teve como preceptor o economista I. Sachs que procurou unir ecologia com economia e utiliza o termo como sinônimo de desenvolvimento sustentável (Schweigert, 2007).

${ }^{17} \mathrm{O}$ conceito contemporâneo de sustentabilidade vem do termo desenvolvimento sustentável e comporta os aspectos apresentados por Sachs. 
desenvolvimento econômico e a preservação da natureza. Com a crise econômica sofrida pelos países da América Latina, dez anos após a Conferência de Estocolmo, o crescimento econômico torna-se prioridade e o desequilíbrio ambiental torna-se problemático; neste cenário o ecodesenvolvimento que perdera sua ação transformadora havia sido substituído pelo discurso do desenvolvimento sustentável (Schweigert, 2007).

Já em 1974 aconteceu a Declaração de Cocoyok, elaborada pela ONU, na qual são apontadas que a pobreza e a explosão demográfica geram desequilíbrio demográfico, destruição ambiental, superutilização do solo e dos recursos naturais (Martins, 2010).

Em 1983 a Assembleia Geral das Nações Unidas criou a Comissão Mundial sobre o Meio Ambiente e Desenvolvimento, UNCED, cuja presidente era a primeira ministra da Noruega, Gro Harlem Brundtland. Esta Assembleia reexaminou "os principais problemas do meio ambiente e do desenvolvimento, em âmbito mundial" e, em 1987, apresentou o relatório 'Nosso Futuro Comum'18 no qual apresenta a "necessidade de conciliar crescimento

\footnotetext{
${ }^{18}$ Segundo Xavier (2011), a definição feita por Brundtland é vaga no sentido de não expor totalmente quais seriam as necessidades presentes e futuras, ou para quem
}

econômico e conservação ambiental"; este documento também apresentou o conceito de desenvolvimento sustentável (Lima, 1997, p. 205).

"O termo 'sustentabilidade' passou a ter seu uso corrente, em nível mundial, a partir de meados de 1980, por iniciativa da Organização das Nações Unidas (ONU). Em 1987, a Comissão Mundial para o Meio ambiente e o Desenvolvimento (CMMAD), pertencente à ONU, divulgou o documento intitulado Our common future ('Nosso futuro comum'). Trata-se de uma obra política e oficial, que expressava a preocupação acerca do então chamado 'desenvolvimento sustentável'. Foi com este documento- popularmente conhecido como Relatório Brundtland, em honra à primeira-ministra norueguesa Gro Harlem Brundtland, então presidente da CMMADque se passou a definir desenvolvimento sustentável como 'aquele que atende às necessidades do presente sem comprometer as possibilidades de as gerações futuras atenderem suas próprias necessidades"” (Xavier, 2011, p. 35).

O termo Triple Botton Line, TBL, surgiu em 1994 a partir de estudos realizados por Elkington, o termo também é conhecido por 3P: 'People, Planet e Profit', segundo Oliveira et. al. (2012, p. 72):

"Analisando-os separadamente, tem-se: Econômico, (...); Ambiental, (...); e Social, (...). Juntos, no entanto, estes três pilares se relacionam de tal forma que a interseção entre os dois pilares resulta em viável, justo

seriam. Porem a ministra já se mostrava preocupada com a união das dimensões políticas, sociais, ambientais e com as escalas locais, regionais e mundiais. 
e vivível, e dos três, resultaria no alcance da sustentabilidade".

Sachs (2008) expõe outros conceitos além do TBL, para o economista a sustentabilidade apresenta dimensões econômicas, sociais, ambientais, culturais, territoriais e políticas nacionais e internacionais. O autor também mostra a relação entre esses conceitos e que, ao priorizar apenas um deles, pode-se estar criando uma deficiência em outro. É preciso tratar esse assunto de maneira pluridimensional, especialmente em países subdesenvolvidos, essa visão torna-se bastante adequada já que também aborda os problemas sociais, além dos ambientais.

São nesses conceitos de sustentabilidade em que este trabalho de pesquisa se apoia.

Martins (2010) também cita o Protocolo de Kyoto, de 1997, que propõe aos países mais industrializados que reduzissem suas emissões de gases de efeito estufa, hoje o documento conta com a assinatura de 184 países $^{19}$.
A Convenção do Clima, a Convenção da Biodiversidade e a Agenda 21 foram adotadas no Rio de Janeiro, em 1992, possuindo recomendações abrangentes sobre o novo tipo de desenvolvimento sustentável. A Agenda 21, particularmente, teve uma enorme influência no mundo em todas as áreas, reforçando o movimento ambientalista (Agopyan e John, 2011).

Segundo Siche (2007 apud Arruda e Quelhas, 2010, p. 55), na Rio 92 houve uma busca para a definição dos padrões e indicadores sustentáveis para o desenvolvimento, foram então criados dois importantes conceitos utilizados para indicar a sustentabilidade: a Pegada Ecológica, que calcula " a área de terra necessária para a produção e manutenção de bens e serviços consumidos por uma (...) comunidade", e o Índice de Sustentabilidade Ambiental, que "mede a capacidade dos países de proteger o ambiente".

\footnotetext{
${ }^{19}$ Como o documento expirou em 2013, houve uma reunião na Dinamarca em 2009 que elaborou um novo documento para substituir o vencido, esse documento também incluiu os países em desenvolvimento.
} 
Três áreas para avaliação de desempenho

Conceito chave: Triple Bottom Line

Sustentabilidade simplificada

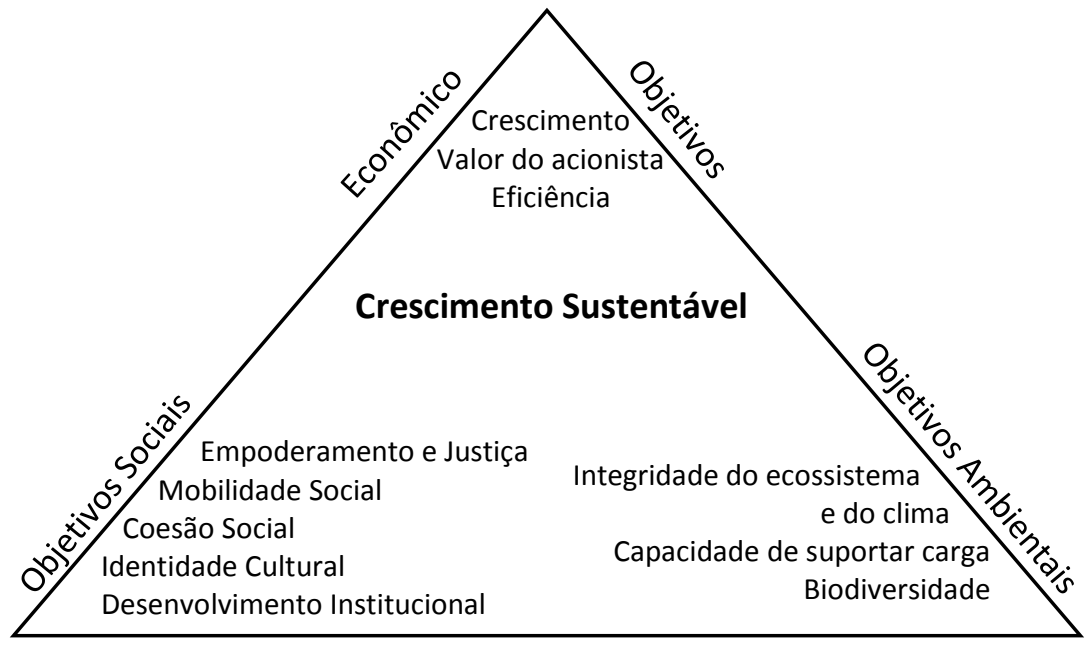

Figura 2- Esquema de crescimento sustentável elaborado pelo World Resources Institute, em 2002, apresentando a tridimensionalidade da sustentabilidade. Na parte superior está indicada a sustentabilidade econômica, na inferior, ao lado esquerdo, está a social e, a direita, a ambiental. (Fonte: Imagem adaptada de Foladori, 2002).

\subsection{O sistema capitalista e o desenvolvimento (in) sustentável}

A atual relação existente entre o capitalismo

sustentabilidade é crítica e para ser inicialmente compreendida é preciso realizar uma pequena digressão histórica: o capitalismo iniciase como uma crise do feudalismo. Com o aumento da população e também da produção no sistema feudal houve um acúmulo de mercadorias que não foram consumidas. Toda esta acumulação gerou a necessidade de criação de um sistema de trocas entre os burgos, trocas estas que evoluíram para o sistema comercial que resultou na criação de cidades e no surgimento da burguesia composta por artesãos e comerciantes (Lessa e Tonet, 2011).

Alguns passos foram importantes para o desenvolvimento do capitalismo, dentre eles: as corporações de trabalho que utilizavam pessoas sem trabalho quando houve a transição do sistema feudal para o sistema de manufaturas, a concorrência entre as nações que deu significado político ao comércio na emergência de lutas entre as nações, as guerras comerciais, e, por fim, o capital móvel gerado pelo comércio e que passa a ser acumulado dando poder à burguesia. 
A burguesia e suas lógicas de produção geraram um rompimento da estrutura feudal e realizaram, de maneira radical, a Revolução Industrial. A nova sociedade capitalista seria dividida entre trabalhadores proletariados e burgueses capitalistas, neste cenário, a força de trabalho do proletariado passa a ser convertida em mercadoria e a riqueza, ou acumulação de capital, sendo direcionada à burguesia, o que acabou gerando um acumulo incessante de capital (Lessa e Tonet, 2011).

Segundo Cunha e Guerra (2012, p. 19-20), Marx compreendia que o homem, através do trabalho, altera a natureza de acordo com suas necessidades ${ }^{20}$ e a organização da sociedade determina a maneira como a natureza é explorada:

"Marx afirma que 'todas as relações sociais estão mediadas por coisas naturais e vice-versa. São sempre relações dos homens entre si com a natureza', significando que a natureza é uma categoria social e a sociedade uma categoria natural".

O próprio capitalismo e seu crescimento econômico implicam na necessidade de dominarem, transformarem e se apropriarem do meio ambiente, a natureza passa a ser mercadoria com valor de troca (Cunha e Guerra, 2012).

Atualmente o sistema capitalista está presente em praticamente todo o mundo, tornou-se financeiro e passou a dominar o mercado global e sendo refletido em diversas atividades do ser humano. Desde sua criação, o sistema tem apresentado uma capacidade de recuperação e reinvenção notáveis, porém a destruição dos recursos naturais se mantém em constante crescimento.

A relação, portanto, entre o capitalismo e o meio ambiente é direta no sentido que o indivíduo submetido a forte ideologia de consumo e alienação, gera um nível de produção intenso que explora os recursos naturais de forma desenfreada e a exploração dos recursos naturais, o que termina por gerar uma situação insustentável como cenário futuro. A grande preocupação atualmente é a relação entre a sociedade e a natureza: atualmente o meio ambiente está debilitado pela grande exploração causada pelo acumulo de capital

do trabalho, e com o desenvolvimento das cidades: "a produção para a troca, no modo capitalista de produzir, implica uma nova relação com a natureza".

${ }^{20}$ Ainda segundo Cunha e Guerra (2012, p. 21), em uma sociedade capitalista a natureza passa a ser controlada por instituições e pelo desenvolvimento da divisão 
de um grupo dominante que não se importa com os impactos ambientais (Welzer, 2010).

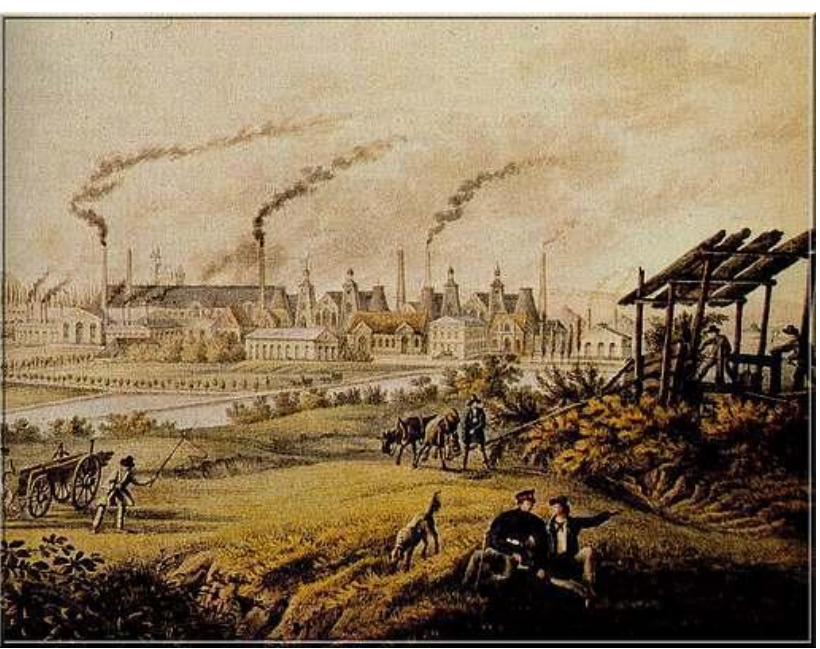

Figura 3- Ilustração de metalúrgica alemã em 1841, autor desconhecido.

A imagem ilustra como a poluição foi intensificada a partir da Revolução Industrial, em consequência do aumento urbano e industrial. Além da poluição, também aumentou o desmatamento para possibilitar a construção de novas

$$
\text { fábricas. }
$$

(Fonte: https://forumdediscursus.wordpress.com/teoria-dos-jogos-e-dacooperacao-para-filosofos/o-jogo-do-bem-publico/, acessado dia 14 de abril de

$$
2015 \text {, as 21:16 horas). }
$$

Segundo Lowy (2013), grandes problemas ambientais também estão relacionados ao processo de mudança climática, resultante dos gases do efeito estufa emitidos pela indústria e pelo agronegócio, em suma, boa parte desse problema resulta do processo de acumulação capitalista gerado pela globalização neoliberal. O planeta e seu meio ambiente estão sendo criticamente atingidos pelo modo de produção vigente: os solos estão se deteriorando pela ação de multinacionais agroalimentares, desertos estão crescendo, florestas estão queimando e vários países sofrem com falta de água e alimentos.

O planeta está atingindo um ponto crítico chamado de não retorno, ou seja, uma temperatura a qual o próprio planeta não terá capacidade de se autorregular. Segundo Marx (2004) os seres humanos possuem a capacidade de alterar qualquer sistema regulatório por intermédio da relação homem-natureza. Considerando esta análise, para enfrentar a crise que se instalou no meio ambiente pela alta taxa de exploração, é necessário que se altere a relação do homem com a apropriação da natureza.

Atualmente os debates estão em torno de encontrar soluções para aliar prosperidade econômica e preservação de recursos naturais. A principal ferramenta teórica para possibilitar a realização prática de um planejamento sustentável é a conscientização ecológica aliada a um planejamento estratégico para que seja possível trabalhar 
de forma racional e agregada, visando conservar o meio ambiente e proporcionar uma alternativa para o futuro.

Com a abertura do foco da sustentabilidade na direção da economia, produção e pessoas, houve um crescimento mais voltado para os seres humanos e para a economia do que para a questão ambiental em si. São, através desta perspectiva, elaborados conceitos das dimensões que a sustentabilidade deveria abranger: (a) Sustentabilidade social: uma sociedade com maior igualdade de distribuição de renda e bens, diminuindo a distância e diferenças entre as classes sociais; (b) Sustentabilidade econômica: a eficiência econômica medida em meios macrossociais e não através de critérios microeconômicos de rentabilidade empresarial; (c) Sustentabilidade ecológica: racionalizar recursos esgotáveis ou danosos ao meio ambiente com redução do volume de resíduos por meio da conservação de energia e práticas de reciclagem, pesquisas em tecnologias ambientalmente mais adequadas e implantação de políticas de proteção ambiental; (d) Sustentabilidade geográfica ou espacial: a configuração rural-urbana mais equilibrada, com a redução de concentrações urbanas e das atividades econômicas, protegendo ecossistemas frágeis; (e) Sustentabilidade cultural: práticas que garantam a sintonia entre as transformações ocorrentes e a continuidade cultural, contemplando a importância das raízes endógenas e especificidades locais do ecossistema (Sachs, 2008).

Binswanger (1997 apud Schweigert, 2007) afirma que o desenvolvimento sustentável é a relação harmônica entre o desenvolvimento econômico e preservação de recursos naturais, sendo assim é importante reconhecer o meio ambiente como base não renovável da existência humana.

Segundo Sachs (2004), os pilares do desenvolvimento sustentável são: social, ambiental, territorial, econômico e político. Analisando os pilares, Sachs conclui que os países devem se desenvolver com suas próprias forças implementando uma estratégia de desenvolvimento endógeno, sem negligenciar sua inserção na economia global. A questão do emprego é vista como fundamental para promover a sustentabilidade social e o crescimento econômico. Sachs ressalta ainda que os países 'periféricos' deveriam se organizar em foros internacionais para promover uma mudança na economia internacional.

O desenvolvimento sustentável indica uma direção na tentativa de solução para o problema. Como citado anteriormente, o 
conceito de desenvolvimento sustentável foi apresentado no Relatório de Brundtland em 1987. O conceito foi consolidado durante a Conferência das Nações Unidas sobre o Meio Ambiente e o Desenvolvimento, ECO 92, e depois amplamente divulgado. A relação e equilíbrio entre o desenvolvimento sustentável e o capitalismo é muito importante para evitar o aumento da depredação e para tentar aliar os processos econômicos com a preservação do meio ambiente.

O desenvolvimento sustentáve ${ }^{21}$ tem como finalidade aliar as preocupações ambientais e políticas socioeconômicas com o intuito destas serem responsáveis pelos impactos ambientais.

Para que haja o desenvolvimento sustentável ${ }^{22}$ é necessário considerar o grande desafio que é fazer a economia desenvolver-se de uma maneira que atenda às expectativas da sociedade e mantenha o ambiente sadio para a atual e futuras gerações. Na verdade, esse desafio é a busca do equilíbrio entre proteção ambiental, justiça social e viabilidade econômica. Aplicar o conceito de desenvolvimento

${ }^{21}$ Segundo a Comissão Mundial sobre o Meio Ambiente e Desenvolvimento (1988 apud Schweigert, 2007, p.79), desenvolvimento sustentável é capaz de satisfazer "as necessidades do presente sem comprometer a capacidade das futuras gerações satisfazerem suas próprias necessidades".

$22 \mathrm{O}$ conceito de desenvolvimento sustentável avançou para um conceito que obedece ao duplo imperativo ético sendo solidário com gerações presentes e futuras, exigindo a explicitação de critérios de sustentabilidade social, ambiental e sustentável é buscar, em cada atividade, formas de diminuir o impacto ambiental e de aumentar a justiça social dentro do orçamento disponível (Agopyan e John, 2011).

Em 2015 foi desenvolvida a 'Agenda 2030' cujas ações englobam as pessoas, o planeta e a prosperidade, além de fortalecer a paz mundial e a tentar erradicar a pobreza para que ocorra o desenvolvimento sustentável. A proposta é que os países interessados e membros da ONU hajam de forma colaborativa. Essa agenda universal possui 17 objetivos e 169 metas para que seja, assim, possível alcançar o desenvolvimento sustentável ao combinar suas propostas com o sistema capitalista e direitos humanos, que atualmente são intensamente discutidos, como a igualdade de gênero e o empoderamento feminino ${ }^{23}$.

de viabilidade econômica (Sachs, 2004). Os países com maior probabilidade de aplicar um desenvolvimento sustentável, capaz de quebrar o ciclo de subdesenvolvimento e pobreza dentro de um esquema de economias mistas e regulamentadas por Estados democráticos, são os países menos desenvolvidos. 23 https://sustainabledevelopment.un.org/post2015/transformingourworld (acessado dia 25 de maio de 2016, as 17:12 horas). 
Os objetivos da Agenda 2030 são ${ }^{24}$ : (a) Erradicar todas as formas de pobreza e em todos os locais, pobreza essa que também inclui privações nas áreas da saúde e da educação; (b) Oferecer de forma efetiva e melhorar a saúde e o bem-estar para todas as faixas de idade, sobretudo combater a mortalidade materna e infantil; (c) Garantir educação e escolas de qualidade, inclusivas e efetivas; (d) Garantir o oferecimento de energia, água e saneamento sustentáveis e confiáveis à toda a população; (e) Empoderar as mulheres e alcançar a igualdade de gêneros; (f) Erradicar a fome e garantir uma alimentação nutritiva e de qualidade; (g) Diminuir as desigualdades entre e nos países incluindo doze dimensões: "coesão social, dependências químicas, doenças mentais, educação, encarceramentos, longevidade, mobilidade social, obesidade, partos de adolescentes, saúde, vida comunitária e violência"; (h) Incentivar a inovação e incentivar indústrias inclusas e sustentáveis; (i) Crescer economicamente de maneira sustentável e inclusiva; (j) Criar maneiras possíveis para ocorra o combate às mudanças climáticas "e seus impactos"; (I) "Tornar as cidades e os assentamentos humanos

24 As informações apresentadas foram retiradas de http://sustentaculos.pro.br/ods.html (acessado dia 25 de maio de 2016, as 17:37 horas). inclusivos, seguros, resilientes e sustentáveis"; (m) "Promover sociedades pacíficas e inclusivas para o desenvolvimento sustentável" com justiça para todos; (n) "Proteger, recuperar e promover o uso sustentável dos ecossistemas terrestres, gerir de forma sustentável as florestas, combater a desertificação, deter e reverter a degradação da terra e deter a perda de biodiversidade"; (o) Conservar e proteger oceanos e mares; (p) "Fortalecer os meios de implementação e revitalizar a parceria global para o desenvolvimento sustentável".

O conceito de desenvolvimento sustentável apresenta diferenças em relação ao conceito de ecodesenvolvimento, dentre as diferenças é possível identificar a distinção entre justiça social, a questão do papel da tecnologia e as diferenças estratégicas políticoeconômicas.

A noção de justiça social para o ecodesenvolvimento busca um teto de consumo com nivelamento médio dos padrões dos dois hemisférios. Já para o desenvolvimento sustentável, foi definido um piso de consumo material com crescimento econômico para dos dois hemisférios, desde que sejam criadas tecnologias mais eficientes. No 
caso da tecnologia, o ecodesenvolvimento defende tecnologias mais adaptadas a cada país e região. O desenvolvimento sustentável defende a transferência de tecnologias. Com relação a questões político-econômicas o ecodesenvolvimento critica o livre mercado e defende uma intervenção maior do Estado, enquanto o desenvolvimento sustentável defende uma política liberal, inclusive a expansão de mercado. Ao que tudo indica, o discurso ambiental vem sendo apropriado pelas forças de mercado.

Segundo Wallerstein (2002), os últimos anos criaram muitos problemas críticos para o meio ambiente como aquecimento global, acidentes nucleares e aumento dos buracos na camada de ozônio. Segundo o autor, os dois problemas principais do capitalismo são o fato de ser um sistema que tem necessidade de se expandir, tanto geograficamente quanto em termos de produção total.

Herculano (1992) critica o conceito de desenvolvimento sustentável pois acaba valorizando muito a questão econômica em relação às questões sociais, culturais, éticos e políticos; este conceito é reinterpretado como lucro e expansão mercantilista e não como realmente deveria ser: nova ética e novos interesses coletivos da sociedade. Um dos caminhos para alcançar o desenvolvimento sustentável respeitando seus conceitos primordiais é a mudança do pensamento que a sociedade tem em relação ao meio ambiente e à natureza.

\begin{tabular}{|lccc|}
\hline & & Impactos \\
& Econômicos & Sociais Ecológicos \\
1. Crescimento desordenado & + & - & - \\
2. Crescimento social benigno & + & + & - \\
3. Crescimento ambientalmente & & & + \\
sustentável & + & - & + \\
4. Desenvolvimento & + & + & + \\
\hline
\end{tabular}

Figura 4- Padrões de crescimento apontados por Sachs (2008, p. 36) que atendem ao mesmo tempo as questões sociais, ecológicas e econômicas, dentro dos três pilares do desenvolvimento sustentável. (Fonte: Sachs, 2008. p. 36.) 
2.3. A transição do atual mundo insustentável para uma nova civilização: as mudanças de paradigmas em relação ao homem e à natureza

Segundo o dicionário Michaelis ${ }^{25}$, paradigma significa:

“sm (gr parádeigma) 1 Modelo, padrão, protótipo. 2 Ling Conjunto de unidades suscetíveis de aparecerem num mesmo contexto, sendo, portanto, comutáveis e mutuamente exclusivas. No paradigma, as unidades têm, pelo menos, um traço em comum (a forma, o valor ou ambos) que as relaciona, formando conjuntos abertos ou fechados, segundo a natureza das unidades".

Em síntese, paradigmas são "estruturas de pensamento que (...) comandam nosso discurso" (Morin, 1997 apud Cunha e Guerra, 2012, p. 81).

Já a mudança de um paradigma pode ser observada como demonstrou o livro 'Estrutura das Revoluções Científicas' de Thomas Kuhn, lançado pela primeira vez em 1962, no qual o autor apresenta as mudanças nas concepções básicas, ou seja, nos paradigmas, dentro de uma teoria que é dominante dentro da ciência. Essas mudanças devem ocorrer de maneira experimental e não somente teórica. Essas

${ }^{25} \mathrm{http} / / /$ michaelis.uol.com.br/moderno/portugues/index.php?lingua=portuguesportugues\&palavra=paradigma (acessado dia 24 de abril de 2016, as 16:48 horas). mudanças de paradigmas devem ocorrer a partir das seguintes condições: (a) É preciso haver insatisfação com o paradigma existente; (b) É preciso que o novo paradigma seja claro e fácil de ser compreendido; (c) É preciso que esse novo paradigma seja razoável e capaz de solucionar os problemas; (d) É preciso que esse novo paradigma possa ser alvo de investigações. A mudança de paradigma para ocorrer, segundo o autor, deve contemplar campos sociais, políticos e pessoais (Kuhn, 1998).

No século XX o ser humano realizou mudanças em diferentes âmbitos, o que também os levou a realizar mudanças paradigmáticas, tudo isso favorece o repensar de "seu papel na sociedade e seu comportamento junto ao meio ambiente de forma mais consciente".

Ainda segundo Brum et. al. (2002, p.2), pode-se reparar em duas posturas do homem: uma voltada para a sua produtividade que tem "como consequências a deterioração da qualidade do meio ambiente" e outra voltada para o equilíbrio e respeito entre a natureza e o desenvolvimento. 
Rohde (1994) afirma que a transição entre o atual mundo insustentável para um mundo que se preocupe mais com a qualidade de vida e do meio necessita de um novo modelo de civilização, assim, novos paradigmas são inevitáveis para fundamentar esse novo mundo.

Segundo Gonçalves (1990, p. 193, apud Brum et. al. 2002), é necessário que essa a visão voltada para o ser humano seja revista e que o homem finalmente aprenda sobre sua dependência com o meio ambiente.

Na tabela 1, retirada de Brum et. al. (2002, p. 03), é possível observar a relação entre os paradigmas, seus equilíbrios e mudanças em relação ao homem e a natureza:

\begin{tabular}{|c|c|c|c|}
\hline & $\begin{array}{l}\text { Paradigma } \\
\text { Dominante }\end{array}$ & Paradigma Perceptivo & $\begin{array}{l}\text { Paradigma } \\
\text { Alternativo }\end{array}$ \\
\hline Valores essenciais & $\begin{array}{l}\text { Crescimento } \\
\text { Econômico; } \\
\text { Ambiente natural, } \\
\text { valorizado como } \\
\text { recurso; } \\
\text { Dominação sobre a } \\
\text { natureza. }\end{array}$ & $\begin{array}{l}\text { Autovalorização com } \\
\text { crescimento } \\
\text { econômico; } \\
\text { Aliar a atividade } \\
\text { produtiva e natureza. }\end{array}$ & $\begin{array}{l}\text { Autovalorização; } \\
\text { Ambiental natural, } \\
\text { valorizado } \\
\text { intrinsicamente; } \\
\text { Harmonia com a } \\
\text { natureza. }\end{array}$ \\
\hline Economia & $\begin{array}{l}\text { Forças do mercado; } \\
\text { Retribuição por } \\
\text { realização; } \\
\text { Auto-suficiência } \\
\text { individual. }\end{array}$ & $\begin{array}{l}\text { Valorizar o interesse } \\
\text { público, dentro das } \\
\text { novas tendências de } \\
\text { sustentabilidade, } \\
\text { conforme figura } 1 .\end{array}$ & $\begin{array}{l}\text { Interesse público; } \\
\text { Renda relacionada com } \\
\text { a necessidade; } \\
\text { Suprimento coletivo- } \\
\text { social. }\end{array}$ \\
\hline Politica & $\begin{array}{l}\text { Estruturas autoritárias } \\
\text { (tecnocratas); } \\
\text { Hierárquico; } \\
\text { Lei e Ordem. }\end{array}$ & $\begin{array}{l}\text { Estruturas } \\
\text { participativas com } \\
\text { envolvimento de todos } \\
\text { os membros, } \\
\text { evidenciando uma } \\
\text { hierarquia construtiva. }\end{array}$ & \begin{tabular}{|l|} 
Estruturas \\
participativas \\
(envolvimento \\
cidadão/operário); \\
Não hierárquico; \\
Libertação. \\
\end{tabular} \\
\hline Sociedade & \begin{tabular}{|l} 
Centralizada e \\
Ordenada
\end{tabular} & $\begin{array}{l}\text { Descentralização } \\
\text { parcial, valorizando a } \\
\text { ordem e a } \\
\text { solidariedade. }\end{array}$ & $\begin{array}{l}\text { Descentralizada e } \\
\text { Flexivel. }\end{array}$ \\
\hline Natureza & $\begin{array}{l}\text { Amplas reservas; } \\
\text { Natureza hostil/neutra; } \\
\text { Ambiente controlável. }\end{array}$ & $\begin{array}{l}\text { Valorização dos } \\
\text { recursos naturais, com } \\
\text { estratégias de } \\
\text { desenvolvimento. }\end{array}$ & $\begin{array}{l}\text { Recursos da terra } \\
\text { limitados; } \\
\text { Natureza benigna e } \\
\text { delicadamente } \\
\text { balanceada. }\end{array}$ \\
\hline Conhecimento & $\begin{array}{l}\text { Confiança na ciência e } \\
\text { tecnologia; } \\
\text { Racionalidade de } \\
\text { meios; } \\
\text { Separação de fato e } \\
\text { valor. } \\
\end{array}$ & $\begin{array}{l}\text { Amplo conhecimento } \\
\text { da ciência e tecnologia } \\
\text { com valorização do } \\
\text { meio ambiente. }\end{array}$ & $\begin{array}{l}\text { Limites para a ciência; } \\
\text { Racionalidade de fins; } \\
\text { Integração de fato e } \\
\text { valor. }\end{array}$ \\
\hline
\end{tabular}


A constituição, então, de um novo paradigma sustentável necessita unir os avanços à sociedade como um todo pois, segundo Rohde (1994), a insustentabilidade presente nos cotidianos é consequência do anterior conhecimento que foi inadequado em relação à vivência com a natureza. Apesar disso, a sustentabilidade ainda não é um paradigma para a sociedade como um todo, não participando de sua cultura e, consequentemente, não participando também dos modos de desenvolvimento da mesma.

\subsection{Cidades Insalubres, Cidades Modernas: renovações urbanas e urbanismo sustentável}

No período pré-histórico, o homem se preocupava sobretudo com seus hábitos de caça e de nomadismo, nesse movimento primitivo de locomoção era possível para a natureza realizar a manutenção dos recursos necessários para o seu sustento. Quando esse homem primitivo se tornou sedentário, ele precisou aprender sobre um inicial plano ambiental ${ }^{26}$ bastante rudimentar e primitivo

${ }^{26}$ O Planejamento Ambiental engloba as seguintes ações do homem sobre a natureza: sua preservação, sua recuperação e sua conservação; atualmente o Planejamento Ambiental deve ser compreendido como "o planejamento das ações sobre quanto tempo a natureza levava para se recompor (Franco, 2001).

Durante a história do ser humano, a natureza foi alvo de destruição seja por intervenção ou por exploração. Segundo Franco (2001) as civilizações como a egípcia, a chinesa e a hindu seguiam uma ética vernacular que permitiu, até o período pré-industrial, que sobrevivessem a partir de "princípios ecológicos" presentes em suas culturas e religiões; com a industrialização e a tecnologia esse fato foi radicalmente modificado.

A partir do domínio do homem sobre o ferro, na Idade do Ferro, foi possível que o homem criasse vários instrumentos entre eles o arado. O cultivo utilizando o arado modificou paisagens e rios, esgotando solos e extinguindo ecossistemas nativos, a consequência a longo prazo foi o processo de desertificação. A exploração da natureza "colaborou expressivamente para o declínio e colapso de inúmeras civilizações ao longo da História" (Herzog, 2013, p. 32). Ainda segundo a autora, o Oriente Médio até hoje sofre as consequências da exploração da natureza que o transformou em um

humanas (da antropização)" que respeitam os meios ambientes locais, regionais, continentais e planetários cujo objetivo é melhorar a qualidade de vida do homem levando em consideração a questão ética ecológica (Franco, 2001, p. 36-37). 
grande deserto a partir de "práticas agrícolas insustentáveis" e destruição de florestas. A exceção é Israel que sempre utilizou de rotações de culturas por questões culturais.

Como dito, antes mesmo do advento do sistema capitalista na sociedade, os povos já sofriam com degradação ambiental e poluição, porém é importante ressaltar, para além do anacronismo do termo, que essas relações com a natureza em sociedades pré-capitalistas eram distintas do que ocorreram após a industrialização ${ }^{27}$ :

"A história das sociedades pré-capitalistas e préindustriais ${ }^{28}$ está assim cheia de exemplos de colapsos sociais alcançados pela depredação do meio ambiente. Evidências históricas e arqueológicas sugerem que as civilizações dos sumérios, do valo do Indo, grega, fenícia, romana e maia tiveram colapsos devidos, em parte, a fatores ecológicos. Finalmente, a condição da campesinato, que constituía a maioria da população mundial antes da Revolução Industrial, estava caracterizada por uma alta mortalidade infantil, baixa esperança de vida, severa desnutrição e açodamento da fome e epidemias- dificilmente uma 'milagrosa

\footnotetext{
27 Segundo Quintana e Hacon (2011, p. 433): "nas sociedades pré-capitalistas, o fraco desenvolvimento das forças produtivas, inclusive da tecnologia, acarretava um enorme impacto sobre a natureza. Nas sociedades industriais, é o elevado grau de desenvolvimento das forças produtivas que, ao operar em um ritmo avassalador, acaba por sobrecarregar a natureza. (...) a busca crescente pelo lucro faz com que a produção de mercadorias deva ser sempre elevada e progressiva, o que gera uma pilhagem dos recursos naturais em larga escala. (...) nas sociedades pré-capitalistas, as depredações eram sentidas regionalmente (...) e dependiam do tamanho da população (...) nas sociedades industriais (...) atingem todo o globo".
}

adaptação à natureza'" (Foster, 1994 apud Quintana e Hacon, 2011, p. 433).

A cidade do século XIX foi palco da revolução industrial ${ }^{29}$ e sofreu com um aumento populacional jamais visto antes. O país vanguardista da revolução, a Grã-Bretanha, no ano de 1800, tinha nove milhões de habitantes nas cidades, sendo que $80 \%$ dessa população vivia no campo, 110 anos depois as cidades contavam com 36 milhões de habitantes, sendo que 72\% vivia na área urbana.

As estruturas medievais e barrocas das cidades europeias não conseguiam se adaptar a essa explosão populacional: as ruas apertadas não eram mais compatíveis ao novo e intenso fluxo do trânsito, como faltavam habitações várias famílias chegaram a dividir um cômodo o que facilitou a propagação de epidemias. Nessas cidades não existiam espaços públicos como parques ou praças.

"O êxodo rural fez explodir a cidade. Era impossíve eliminar apenas através de infra-estruturas ou da

${ }^{28}$ Segundo Franco (2001), as grandes civilizações sobreviveram por um longo período de tempo pois possuíam uma organização norteada por princípios ecológicos, conhecidos hoje como algo muito próximo ao planejamento ambiental inclusos nas religiões e na própria cultura desses povos.

${ }^{29}$ A Segunda Revolução Industrial iniciou-se no final do século XVIII e teve como maior consequência a alteração do trabalho e da produção do sistema capitalista. Essa moderna forma industrial possuía novas e diferentes formas de organização e técnicas de produção, além de grande quantia de mão de obra e maiores investimentos de capitais (Caram, 2014). 
arquitectura os problemas subsequentes. Deste modo, nasceu uma nova disciplina: o urbanismo. Os urbanistas encontraram os seus primeiros modelos no local de origem dos problemas da cidade, ou seja, projectaram no campo a nova cidade como antítese da antiga" (Tietz, 2008, p. 40).

Engels em 1845 aponta em seu livro 'A situação da classe operária na Inglaterra' a insalubridade dos edifícios habitacionais operários e das vias, o congestionamento das cidades, a falta de segurança das construções, a falta de saneamento e do tratamento de detritos e a falta de legislação para o aproveitamento do solo.

Londres ainda contava com o problema da poluição por esgoto e águas negras do Tâmisa que era o rio responsável pelo abastecimento de água da cidade, esse fato fez aumentar as epidemias $^{30}$. Nos anos seguintes foram realizados estudos técnicos para melhorar essa situação, chegando a conclusão de que faltavam leis sobre construções e instalações urbanas, no ano de 1845 foi

30 Spirn (1995), faz uma análise realista e uma previsão de como estaríamos atualmente ainda na década de 1990. O cenário apresentado de consumo desenfreado de recursos e geração de resíduos só se agravou nos últimos anos e os problemas de deslocamento das cidades, apresentado como um dos principais causadores de poluição nas grandes cidades: o deslocamento de milhares de pessoa dos subúrbios para o centro. Outro exemplo utilizado é a criação de jardins que exigem tratamento com água, corte de plantas e adubação, acabam resultam em resíduos e desperdiçam energia. O argumento principal é que as formas criada a Comissão Real para dar continuidade aos estudos das grandes cidades e dos distritos populosos cujo relatório conclui que, antes da elaboração de um projeto de rede de esgotos, era necessário realizar obras de pavimentação e oferecer às residências alguns requisitos mínimos de higiene; também concluíram que era necessário alargar as ruas e criar parques públicos. Com essas exigências sanitárias chegaram a um programa urbano completo (Benevolo, 2014).

Ainda segundo Benevolo (2014), as cidades estavam crescendo de uma maneira que jamais havia ocorrido anteriormente, as melhores condições de higiene contribuíram para o aumento populacional e, juntamente com a intensa migração, ocorreu o aumento da quantidade de habitações construídas; era imperativo que houvesse uma evolução na maneira que as obras eram construídas no sentido de otimizar o tempo de execução.

naturais isoladas não são parte de um processo em evolução. A autora conclui que custos e benefícios calculados sem uma avaliação do sistema como um todo e dos processos que o impelem subestimam invariavelmente o valor da natureza na cidade. A crítica maior é com relação aos projetistas que trabalham apenas em uma dimensão, a do seu próprio projeto, e não se preocupam com o impacto em outras áreas, como o consumo de energia, diminuição de recursos, poluição da água e do ar, enchentes e contaminação do solo. 
As mudanças e os acontecimentos que ocorreram na Revolução Industrial na Inglaterra foram refletidos em outros países europeus, num período maior ou menor de tempo, com o "aumento da população, aumento da produção industrial e mecanização dos sistemas de produção" (Benevolo, 2014, p.21).

Neste cenário, Choay (2015) fala sobre as grandes mudanças que ocorreram para modificar as cidades insalubres transformandoas em cidades adaptadas à nova realidade e às novas pessoas, como racionalizar as vias de circulação e especializar os setores urbanos; nasce aqui a suburbanização e o fim da delimitação urbana pela transferência das indústrias para os subúrbios e, consequentemente, o deslocamento das classes operárias; a autora fala que no ano de 1861 o subúrbio de Londres correspondia a 13\% da aglomeração urbana e, em Paris, 24\%, no ano de 1896.

Os parques ${ }^{31}$ surgiram como uma resposta aos problemas urbanos causados pela Revolução Industrial, sobretudo como solução às doenças causadas pela superlotação das cidades. Além da proteção

31 Um modelo de urbanismo a ser citado é o Progressista; inicialmente, este modelo defendido por intelectuais como Owen (1771-1858), Fourier (1772-1837), Cabet (1788-1856) e Proudhon (1809-1865) propõe ordem ao caos da cidade industrial utilizando-se, entre outras propostas, de espaços abertos e verdes. ambiental, as funções dos parques são: recreação, estruturação urbana, estética, contemplação, atividades sociais e culturais, uso voltado para a educação e função orgânica ou ecológica (Silva e Pasqualetto, 2013).

A partir do século XVIII, Londres passa a contar com praças e parques que tornam a cidade repleta de gramados e árvores, o jardim inglês é a ligação com a natureza (Benevolo, 2014).

Paris foi um importante exemplo da reestruturação da cidade que se tornava industrial, Georges Eugène Haussmann ${ }^{32}$, a pedido de Napoleão III, reforma a cidade criando jardins e parques urbanos visando melhorar o fluxo da população e das mercadorias e melhorar a salubridade da cidade. Em questões paisagísticas, os projetos de Haussmann são bastantes semelhantes aos espaços urbanos da Inglaterra (Howard, 1996).

Segundo Choay (2015, p. 04) essa nova organização urbana seguiu os seguintes princípios: (a) "Racionalização das vias de comunicação, com a abertura de grandes artérias e a criação de

Proudhon, por exemplo, defendia a transformação da França em um grande jardim com pequenos bosques (Choay, 2015).

32 Choay (2015) fala que as mudanças feitas por Haussmann prejudicaram e incomodaram os operários e pequenos burgueses que foram expropriados, porem favoreceram os capitães industriais e os financistas. 
estações"; (b) Agrupamento de setores urbanos; (c) Criação de novos órgãos, como grandes hotelarias e prédios para aluguel; (d) Pela urbanização que estava ocorrendo, as indústrias passaram a se instalar em espaços urbanos mais afastados, assim como as classes médias e operárias.

O Urbanismo é uma disciplina com uma longa tradição, as concepções de "urbanização" e "urbanismo" já foram aplicadas no final do século XIX e no início do século XX. O Urbanismo desenvolveuse como ciência moderna, a partir do século XIX, resultante da união de disciplinas como sociologia, economia e arquitetura. Era preciso resolver de maneira eficiente os sérios problemas urbanos, sociais e econômicos acarretados pela Revolução Industrial (Argan, 1995). Pelo caos das cidades industriais e pela falta de contato com a natureza nascem diversos projetos para a construção de uma cidade ideal.

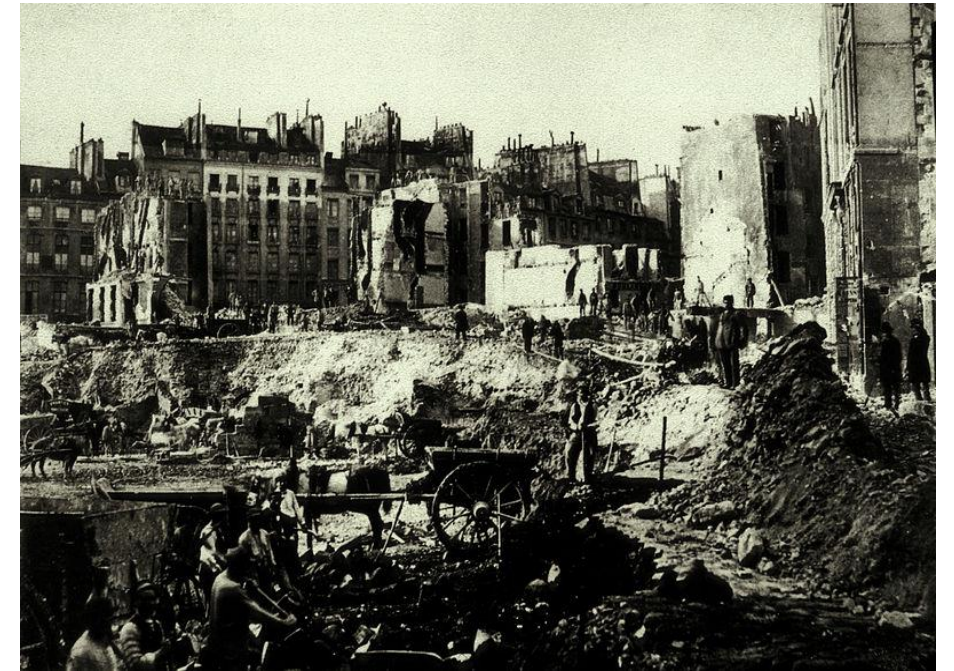

Figura 5- Fotografia mostrando a demolição entre a rua de l'Échelle e Saint Augustin para as reformas urbanas realizadas em Paris, 1877, fotografia de Charles Marville.

$$
\text { (Fonte: }
$$

https://commons.wikimedia.org/wiki/File:Between_Rue_de_l\%27\%C3\%89chelle_ and_Rue_Saint_Augustin_-_demolition.jpg, acessado dia 24 de agosto de 2015, as 11:42 horas).

Desde a Revolução Industrial, pensadores já buscavam por esses valores mais puros e simples, porém a conservação ambiental em si só apareceu a partir de autores norte-americanos do século XIX, nesse período a natureza é compreendida a partir de uma visão romântica (Franco, 2001).

Ainda segundo Franco (2001), um exemplo a ser citado de um pensador americano que defendia a hegemonia da natureza é o 
utopista Henry David Thoreau (1817-1862), segundo o autor e fundador do movimento romântico transcendental, era necessária a rebelião contra as instituições e buscar abrigo na natureza.

Frederick Law Olmsted (1822-1903), também norte americano

\begin{abstract}
"acreditava que o crescimento rápido da população urbana tornava impraticáveis os ideais da democracia, devido, principalmente, à imigração (...) e o uso impróprio dos espaços urbanos, agravados pela exploração do trabalho" (Franco, 2001, p. 94).
\end{abstract}

Olmsted teve contato, em 1850, com distintos projetos e profissionais britânicos como Joseph Paxton e seu Plano de Birkenhead que, em síntese, alocavam habitações ao longo das bordas de um parque, favorecendo o meio ambiente e toda a vizinhança; esse projeto serviu de inspiração para Olmsted que compreendeu que os parques poderiam trazer um pouco do contato com a natureza para áreas insalubres (Schenk, 2008).

Até o ano de 1858, o que atualmente é conhecida por 'Arquitetura Paisagística' era praticada por jardineiros, engenheiros, horticultores e arquitetos que tiveram um ensino "informal e fragmentado" (Franco, 2001, p. 94-95).
Diversas utopias, ou modelos, que se desfaziam ou melhoravam as cidades antigas foram desenvolvidas no início do século XX, essas ideias apresentavam uma preocupação futura acerca da possível escassez de recursos naturais e que iriam na contramão daquele momento em que o liberalismo econômico acreditava que a natureza era composta por recursos inesgotáveis (Franco, 2001). Essas ideias buscavam resolver os problemas enfrentados pela cidade industrial.

Um exemplo são as cidades-jardim de Ebenezer Howard (1850-1928). A sua ideia de cidade-jardim era a criação de comunidades planejadas com densidades bem menores que a de Londres, e que fossem autogovernadas.

“(...) o maior dos enganos foi vê-lo como um planejador físico, esquecendo que suas cidades-jardim eram meros veículos para a reconstrução progressiva da sociedade capitalista dentro de uma infinidade de comunidades cooperativas" (Hall, 2013, p. 103)

Quando Howard propôs as cidades-jardins, diversas manifestações e autores na Europa já falavam do retorno a uma "vida mais simples, centrada em artesanato e comunidade" (Hall, 2013, p. 108). 
Ainda segundo Hall (2013, p. 100), a proposta apresentada para a cidade-jardim eram 32.000 moradores "para 1000 acres de terra, perto de uma vez e meia mais que a cidade histórico- medieval de Londres", circundando essa cidade haveria um robusto cinturão verde (5.000 acres) que também contaria com granjas e outros serviços como reformatórios e casas de repouso.

Cada cidade-jardim iria contar com um amplo leque de empregos e serviços, além de um sistema de transporte rápido e eficiente, era uma cidade social.

Uma experiência inspirada no movimento das cidade-jardins é realizada em 1895 por G. Cadbury numa área próxima a Londres: quinhentas habitações foram construídas num terreno com aproximadamente cento e oitenta hectares. A partir de 1898 outras iniciativas seguidoras do Movimento foram realizadas. Howard pensava que a propriedade privada dos terrenos construídos produzia um valor imobiliário da periferia para os centros urbanos fazendo com que os proprietários aproveitassem seus terrenos aumentando suas densidades. Se a especulação imobiliária fosse extinta, os edifícios poderiam virar amplos espaços verdes e o campo poderia estar sempre acessível. A ideia das cidades-verdes é manter a salubridade, o verde e a tranquilidade das cidades (Benevolo, 2014).

Ainda segundo Benevolo (2014), a importância das cidadesjardins é grande pois habituou os arquitetos a pensarem e considerarem a paisagem urbana como um organismo orgânico inserido e participante da vida das cidades, que tem o poder de modificar o ambiente em congruência com ele. 


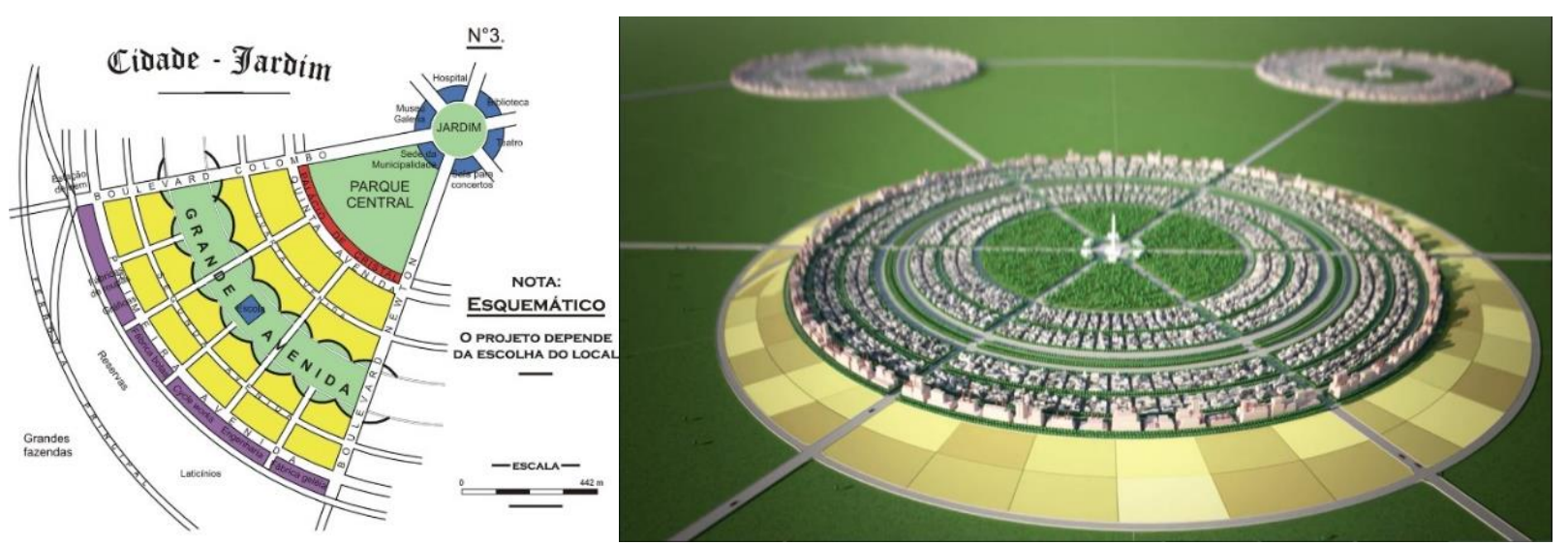

Figura 6- Montagem com imagens da cidade jardim. A direita há a planta esquemática onde o centro é composto por serviços coletivos e áreas verdes aumentando a eficiência energética da cidade; a direita há a maquete eletrônica representando teoricamente as ideias de Sir Ebenezer Howard, sem data, sem autoria.

(Fonte: http://equilibrium.org.br/portal/ecopolos/, acessado dia 24 de agosto de 2015, as 13:45 horas).

Ao contrário dos pensadores europeus do século XIX, que criticavam e repensavam as cidades industriais, nos Estados Unidos ocorreu o oposto: com o início da industrialização no país, autores norte-estadunidenses cultivavam a ideia de natureza virgem e, por essa razão, ocorreu no país uma "corrente antiurbana" 33 (Choay, 2015, p. 17).

${ }^{33}$ Segundo Choay (2015, p. 17), uma das correntes antiurbanas vieram de autores como Thomas A. Jefferson e Louis Sullivan que, em síntese e em comum, defendiam a ideia de um: "estado rural, que eles pensam ser, com algumas
Essa corrente também foi considerada pela autora como um modelo utópico que seguiu pelo século XX e que também foi desenvolvida por Wright, num modelo que foi bastante ruralista.

O arquiteto Frank Lloyd Wright (1867-1959) com sua ideia chamada 'Usonia' tinha como objetivo unir as pessoas ao meio ambiente através de uma unidade orgânica, sendo possível afirmar que as ideias do arquiteto se aproximam das de Howard. Em 1935 foi

reservas, compatível com o desenvolvimento econômico da sociedade industrial e que sozinho permite assegurar a liberdade, a manifestação da personalidade e até a verdadeira sociabilidade". 
elaborado um projeto para uma cidade usoniana chamada 'Broadacre City $^{34}$ onde a cidade era tomada pela natureza. Lá, cada família era dona de meio hectare e deveria desenvolver suas próprias atividades agrícolas e comercializar o que produzissem. Atualmente podemos vislumbrar vários pontos das ideias de Wright nos subúrbios dos Estados Unidos, porem as propostas individualistas mostraram-se inconciliáveis com o planejamento centralizado (Tietz, 2008).

Wright também teve uma grande preocupação com a relação do meio ambiente com suas obras; suas ideias muitas vezes se aproximaram do urbanismo que será conhecido como sustentável, em que afirmava a ideia de que era possível colocar toda a população dos Estados Unidos numa área do tamanho do Estado do Texas e que todo o restante do país "poderia ser uma imensidão verde" (Franco, 2001, p. 106).

Tietz (2008) explica que, enquanto Howard e Wright pensavam numa sociedade vivendo mais próxima à natureza, o

\footnotetext{
${ }^{34}$ Segundo Lotufo (2011, p. 39) a Broadacres City incluía 'áreas de cultivo agrícola, tipos residenciais de tamanhos variados, escolas, universidade, serviços de saúde, mercados, áreas de lazer, áreas esportivas, áreas de visitação turística, hotéis, indústrias de pequeno porte e escritórios. Para algumas áreas (...) previa-se a existência de centros cívicos, com zoológicos, centro de pesquisas agrícolas e aeroporto".
}

arquiteto Tony Garnier propunha ${ }^{35}$, em 1904, uma cidade industrial moderna chamada 'Cité Industrielle' com setores reservados para moradias, trabalho, lazer e circulação. A circulação era composta por vias rodoviárias e para pedestres, mas a cidade tinha mais da metade de sua área coberta por áreas verdes; os blocos de habitações ficavam isoladas e independentes no meio desse espaço e eram construídas de maneira industrial.

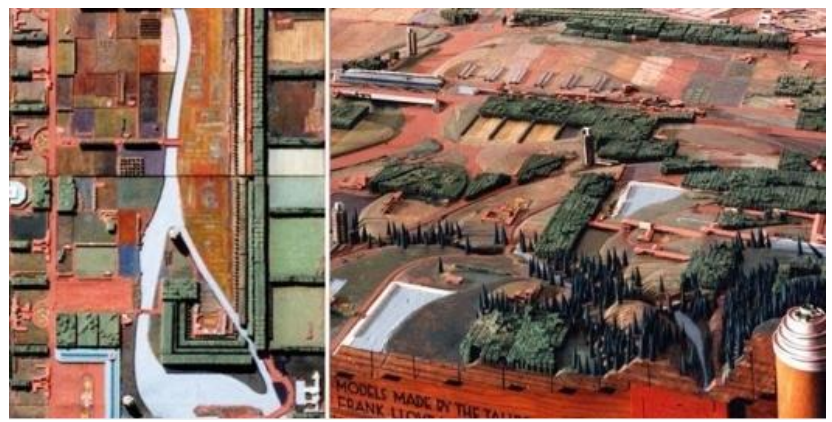

Figura 7- Maquete da Broadacre City cujos conceitos são meio ambiente, desenvolvimento sustentável e ecologia social, sem data. (Fonte:

http://www.vitruvius.com.br/revistas/read/arquitextos/08.095/148, acessado dia 24 de agosto de 2015, as 13:29 horas).

35 As ideias de Garnier abriram campo para a elaboração dos princípios fundamentais da Arquitetura Moderna. Uma ideia que se desenvolveu a partir das de Garnier foi o plano da 'Ville Contemporaine', na qual Le Corbusier tinha a pretensão de abrigar 3 milhões de moradores num edifício de 60 andares (Tietz, 2008). 
Após a Primeira Guerra Mundial, grandes arquitetos como Gropius e Le Corbusier estreitam a relação entre o Urbanismo e a Arquitetura, ou seja, o arquiteto seria responsável pela elaboração de um ambiente constituído pela coordenação de elementos. O Modernismo defende uma cidade ativa e moderna (Argan, 1995).

Os arquitetos modernos pretendiam superar o dualismo entre o campo e a cidade apropriando-se de modo singular do território urbano $^{36}$; eles são contra a união dos interesses públicos com a propriedade particular e almejam pela reconquista do "controle público sobre todo o espaço da cidade" (Benevolo, 2015, p. 631).

Em 1933 foram elaborados no quarto Congrès Internationaux d'Architecture Moderne, CIAM, os planos teóricos a favor de uma nova cidade através da Carta de Atenas:

"Onde a cidade tradicional estabelecia fronteiras com o campo, se baseava na divisão do trabalho, assim como em esferas de influência públicas e privadas, onde vias, praças e parques públicos se distinguiam claramente das edificações privadas e o urbanismo era

36 A Arquitetura Moderna também gerou alguns problemas "como a descaracterização e perda de identidade de centros históricos; a concentração urbana e consequente perda da escala humana das cidades contemporâneas; e o menosprezo das questões ambientais, o que provocou graves impactos ecológicos" (Xavier, 2011, p. 41). "O concreto e o aço são os materiais de separado da arquitectura, a cidade do Modernismo defendia um espaço habitacional homogêneo, público, permeado de áreas verdes, organizado por um planeamento estatal centralizado. (...) a cidade do modernismo contrapunha uma separação das funções e uma concepção hierarquizada do tráfego. A questão da habitação e a crise que esta instalara na cidade antiga já não deveria ser deixada nas mãos de especuladores, mas sim solucionada com edifícios de alojamento em massa, erigidos pelo estado, cujas condições de habitação padronizadas deveriam oferecer luz, ar e sol para todos" (Tietz, 2008, p. 66)

A Carta de Atenas foi base instrução por muitos anos para o planejamento de diferentes cidades ao redor do mundo, sobretudo após a Segunda Guerra Mundial.

Os arquitetos modernos eram, sobretudo, a favor do desenvolvimento científico e contra a cidade oitocentista, ou seja, contra o anacrônico e ilógico modelo urbano destas cidades. Em síntese, o legado modernista apresentou a preocupação e a necessidade de interagir o homem com a natureza, mantendo a harmonização entre o edifício e os espaços livres ${ }^{37}$.

construção que mais contribuíram para as mudanças climáticas" (CIB/UNEP-IETC, 2002 apud Xavier, 2011, p. 41)

${ }^{37}$ Segundo Choay (2015, p. 22), após a Primeira Guerra Mundial os arquitetos mudaram a gestalt em termos de "forma e fundo": os espaços urbanos verdes aproximaram a cidade do campo, passando a ter maior importância e não mais sendo encarados como um fundo figurativo das construções; importantes 
No ano de 1937, Londres nomeia uma comissão para estudar a distribuição das industrias e da população na tentativa de enfrentar as consequências da crise de 1929; em 1938 a cidade cria uma lei que limitava a expansão da cidade, inserindo ao redor da área urbana uma zona agrícola em formato de coroa- o cinturão verde. Após os bombardeios sofridos pela capital britânica na Segunda Guerra foi preciso reconstruir a cidade e, para isso, foi proposto um plano por arquitetos modernos que compactava Londres em "duas fileiras de quarteirões alternados com zonas verdes", porem o Condado escolhe outro plano que extinguia o cinturão verde para possibilitar o futuro aumento da cidade e viabilizava de mais oito cidades na zona externa de Londres. Essas cidades novas, New Towns, lembravam muito as cidades-jardins no tamanho, baixa densidade e habitações integradas com o jardim, essas cidades compreendiam amplas zonas verdes e áreas industriais próximas as ferrovias; no centro estavam o comércio e escritórios e nas zonas verdes, estradas de alta velocidade e outros serviços como ensino superior (Benevolo, 2015, p. 681).
Apesar das preocupações que esses profissionais tinham com a inserção do verde no tecido urbano, eles ainda não são considerados ambientalistas.

Até a década de 1970 os arquitetos não se preocupavam com os impactos ambientais gerados pela construção de seus projetos pois compreendiam que eram insignificantes as trocas do edifício com o entorno, em questões energéticas; o edifício era projetado e construído como um organismo autônomo. Não eram considerados os transportes dos materiais de construção ou a adaptação dos edifícios ao clima (Xavier, 2011).

Nos anos 1990 o alemão Dieter Hoffmann-Axthelm preocupase se é possível unir essa questão ao planejamento de uma forma que garanta o desenvolvimento urbano duradouro. Ele acredita que os eixos viários históricos devem manter a estrutura da cidade garantindo que os objetivos urbanos sejam alcançados ao evitar que o desenvolvimento de uma parte da cidade ocorra à custa das outras (Tietz, 2008) 
A Alemanha é um importante exemplo por ações de preservação ambiental ${ }^{38}$, reciclagem de resíduos e melhorias na área de engenharia ambiental: entre 1984 e 1989 projetos de ecologia urbana foram criados a partir de projetos do arquiteto Ekhart Hahn.

Nesta demonstração de projetos organizada pela cidade de Berlim foram apresentados quatro elementos essenciais: (a) Oito pontos de orientação, que foram modelos para os projetos específicos; (b) Campos de atuação e módulos, que foram a "estrutura para o desenvolvimento das estratégias políticas específicas, aplicáveis aos projetos e às diferentes medidas (...) de grande alcance"; (c) Desenvolvimento econômico de bairro, que alcança o nível dos moradores permitindo "a ação fundamental da reestruturação urbana ecológica, (...) referente à criação de medidas adequadas do ponto de vista técnico, social, de planificação e de desenho urbano"; (d) Ecoestação, que permite a "reestruturação urbana ecológica" (Franco, 2001, p. 68) 39.

\footnotetext{
${ }^{38}$ Segundo Franco (2001, p. 89), a conservação ambiental é originária da América e pode ser compreendida como: "O convívio e harmonia do homem com a natureza com o mínimo impacto possível, isto é, sem esgotar os recursos ambientais, permitindo a vida das gerações futuras".
}

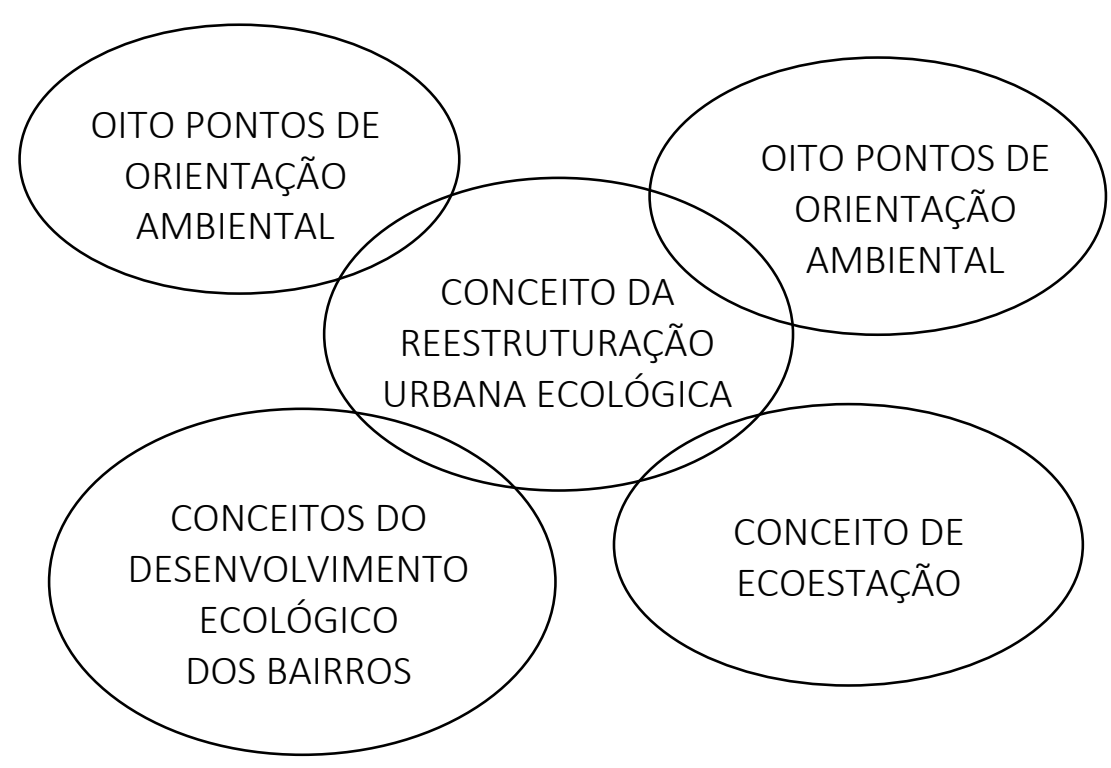

Figura 8- Esquema da Estruturação Urbana Ecológica, Eckart Hahn, Berlim, 1984 (Fonte: Franco, 2001. p. 69).

39 É pertinente ressaltar as diferenças, enquanto a Alemanha tem uma preocupação de unir o planejamento com questões ambientais e de salubridade, no Brasil isso não ocorreu. O Brasil possui uma carência em ações fundamentais em relação ao meio ambiente, faltando organicidade. 
No Brasil, a preocupação com a conservação ambiental apresentou-se no início do século XIX a partir de influências de naturalistas estrangeiros que vieram ao país, juntamente com Dona Leopoldina, futura imperatriz do Brasil (Franco, 2001).

Apesar de iniciativas de pesquisadores, o Código Florestal Brasileiro e o Código das Águas foram criados somente em 1934, segundo Franco (2001), até então só existiam no país duas reservas florestais: o Alto da Serra, SP, e a Itatiaia, RJ.

Em São Paulo, capital, entre os anos de 1890 e 1900 houve um crescimento populacional de $269 \%$ contra $55 \%$ na cidade do Rio de Janeiro, isso ocorreu porque o mercado de construção civil estava crescendo e se desenvolvendo muito mais na cidade paulista do que na capital federal. Esse crescimento urbano impactou a economia do Estado de São Paulo (Ficher,2005).

Na capital paulista a criação de novos bairros e loteamentos aumentou a construção de edifícios privados, segundo Ficher (2005) foi o 'Boom' comumente citado na literatura. A maioria dos loteamentos do período foram criados em traçado xadrez o que resultou num bom aproveitamento da área das glebas ${ }^{40}$.
Em 1915 a City of São Paulo Improvements and Freehold Land Company, Cia. City, projetou o Jardim América seguindo o modelo original da Garden City, as cidade-jardim, com traçado curvo das vias e com o isolamento das edificações. A construtora seguiu o modelo inglês e utilizou lotes maiores que os padrões paulistas sem, necessariamente, implicar um aproveitamento melhor da área; esse projeto garantiu condições sanitárias e higiênicas para a época, além de criar um local com "status social” (Ficher, 2005).

A partir de 1930 a cidade de São Paulo torna-se o maior centro industrial do país contando, em 1940, com uma população de 1,5 milhão de habitantes sendo iniciado, então, seu processo de metropolização. Nesse período começam as discussões acerca do Urbanismo e do planejamento das cidades (Nobre, 2006).

Para limitar a verticalização do centro, a Prefeitura promulga a Lei 2.332/1920 que limita a altura dos prédios para 2 ou 3 vezes a largura da rua, nas outras zonas essa altura estava limitada a 1,5 vezes. Anos depois foram permitidas exceções que chegaram a 80 metros.

\footnotetext{
${ }^{40}$ Glebas são terras não parceladas, loteadas ou desmembradas.
} 
Assim, a cidade que não se destacava tanto no cenário brasileiro foi sendo transformada na cidade cosmopolita de São Paulo (Silva e Paqualetto, 2013).

As manifestações e iniciativas apresentadas foram inspiradas em ações que já aconteciam fora do país, colaborando para a construção de uma cidade mais salubre e com mais espaços verdes. Contudo, a presença dessas áreas dentro do espaço urbano não significa um ideário ambiental, mas sim um primeiro momento nem que as questões relacionadas ao meio ambiente se apresentam na cidade. A sustentabilidade, que relaciona questões ambientais, econômicas, sociais e culturais, ainda precisaria chegar ao final do século XX para se consolidar como um ideário paradigmático.

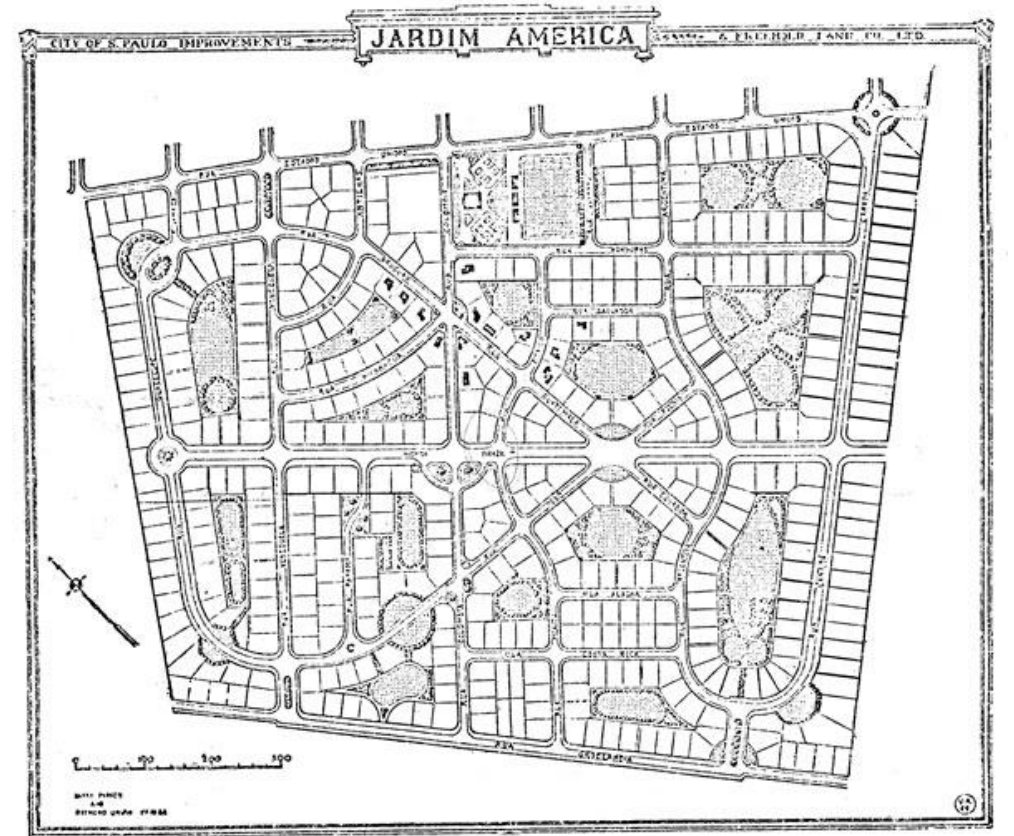

Figura 9- Mapa Jardim América feito pela City of São Paulo Improvements and Freehold Land Ltd., sem data.

(Fonte: http://acervo.estadao.com.br/noticias/acervo,jardim-america-dalama-ao-luxo,7201,0.htm, acessado dia 24 de agosto de 2015, as 19:28 horas) 


\subsection{Arquitetura e Urbanismo Sustentáveis: importâncias e aplicações}

O Urbanismo Sustentável abrange amplas questões sociais referentes ao Movimento Ambientalista, "assim como as potenciais consequências de longo prazo para nossa compreensão das cidades". Os Urbanistas precisam olhar para o Urbanismo Sustentável como uma resposta atemporal aos problemas causados pelas mudanças climáticas e os limites dos recursos naturais (Mostafavi e Doherty, 2014, p. 208). Esse Urbanismo pode ser a reação comum das pessoas à contracultura que nasceu após a crise energética de 1973: eco aldeias, eco vilas, eco bairros, eco ilhas, eco cidades e eco regiões; muitos desses empreendimentos ficaram somente na teoria mas demonstram a vontade popular de retomar a relação e o cuidado com o meio, muito além de apenas diminuir a poluição ambiental ou o consumo desenfreado, essa preocupação das pessoas transmite o desejo em criar soluções efetivas que atendam demandas públicas, criando espaços para que a comunidade possa imaginar seu futuro.

\footnotetext{
${ }^{41}$ http://www.bbc.com/portuguese/noticias/2015/06/150622_cicloativismo_sao _paulo_rb (Acessado dia 27 de agosto de 2015, as 13:38 horas).
}

As cidades também são sustentáveis por sua mobilidade urbana e acessibilidade, ícones importantes do Urbanismo Contemporâneo. O crescente e descontrolado uso de automóveis particulares impacta os tecidos urbanos com tráfegos intensos que atravessam uma longa e densa faixa de construções, é fato que o crescimento desenfreado e sem planejamento das cidades acaba inviabilizando a locomoção por pedestres, bicicletas (que acaba sendo um transporte perigoso aos ciclistas) e o oferecimento de transportes públicos efetivos. As distâncias tornam-se cada dia maiores e a cultura, sobretudo em países menos desenvolvidos, do transporte particular transforma o caos da cidade em um padrão de mobilidade insustentável. Claro que existem iniciativas para uma adaptação mais sustentável do trafego urbano, como a recém-inaugurada ciclovia da capital paulista ${ }^{41}$, porém ainda é preciso a aceitação dos moradores e, principalmente um projeto mais seguro ${ }^{42}$.

Segundo Rogers (2014, p.120), o veículo não é um problema somente pela poluição, mas também pelo medo causado; essa junção

42 http://infograficos.estadao.com.br/public/cidades/ciclovias/ (Acessado dia 27 de agosto de 2015, as 13:45 horas). 
de fatores motivam as famílias a saírem dos centros das cidades ${ }^{43} \mathrm{e}$ modificam o comportamento das pessoas, por exemplo, atrasando a independência das crianças cujos pais têm medo de deixa-las atravessarem as ruas sozinhas. As políticas públicas atuais também incentivam o aumento do consumo e uso de carros; "a separação dos locais de moradia, compras e trabalho, e a deterioração do transporte público tornaram o automóvel um meio de transporte indispensável".

É preciso que os urbanistas encarem a fragilidade do planeta e a escassez dos recursos como oportunidades para inovar, desenvolver e ampliar as pesquisas e projetos urbanos, arquitetônicos e de materiais, o que necessariamente redefine a prática profissional e abre campo para a discussão do futuro da mesma. O ensino de Arquitetura e Urbanismo sustentáveis deve ser multidisciplinar e colaborativo pois é algo amplo e muito abrangente; esse ensino deve aproximar arquitetura, infraestrutura, sociedade, meio ambiente e tecnologia.

Os arquitetos e urbanistas viram a paisagem e a sustentabilidade tornarem-se vetores primários do Urbanismo e da

${ }^{43} \mathrm{O}$ autor ainda ressalta a importância de recuperar as regiões abandonadas, criando áreas compactas e funcionais em torno do transporte público. Para criar
Arquitetura Contemporâneos, a sustentabilidade está passando de teoria para prática urgente e imprescindível na tentativa de reconfigurar e salvar cidades. Por muitas vezes, na ânsia de responderem as pressões relacionadas aos problemas ecológicos, os profissionais acabam tentando realizar seus projetos dentro do que compreendem ser sustentável, ignorando, quase sempre, todas as vertentes que o conceito engloba, o que torna o resultado pobre, vago e ineficiente. Atualmente o Urbanismo parece estar indissociável da sustentabilidade e, consequentemente, a sustentabilidade urbana tornou-se um tema e preocupações atuais.

A arquitetura surgiu pela necessidade do homem em obter abrigo. Atualmente a arquitetura se volta quase que exclusivamente para o lucro, que determina formas, qualidades e desempenho. Esse fato acaba por desestimular grande parte das construtoras a pensar na sustentabilidade como solução a longo prazo. Esse pensamento insustentável acaba por influenciar a Arquitetura e o Urbanismo Sustentáveis. comunidades sustentáveis é necessário também criar uma efetiva e acessível rede de mobilidade urbana. 
Apesar desse cenário de arquitetura mercadoria ${ }^{44}$, é importante que os profissionais transcendam essa problemática com o intuito de encontrar soluções pensando no futuro e não somente na resolução imediata dos problemas, voltando suas pesquisas e projetos em iniciativas mais sustentáveis para transformar a Arquitetura e o Urbanismo em locais melhores habitáveis. Ao mudarmos nossa mentalidade, mudamos também as legislações vigentes.

É possível perceber que muitos dos conceitos de sustentabilidade estão presentes na Arquitetura Vernacular ${ }^{45}$ que pode contribuir muito no ensino de técnicas e soluções, além de permitir a melhora do ambiente construído.

Também há a Arquitetura Ecológica que "utiliza o máximo de matéria-prima local e materiais reciclados e o mínimo de materiais industrializados, buscando a máxima auto-suficiência de energia e água, reduzindo, reutilizando e reciclando, e principalmente aliando

\footnotetext{
${ }^{44}$ Segundo Rogers (2014, p.118), empreendimentos arquitetônicos são "feitos para atender à demanda do consumidor, em vez de consolidar a vizinhança. Como resultado são rejeitadas propostas densas com áreas públicas, praças e parques, englobando lojas, locais de trabalho e escolas- exemplos de uma comunidade sustentável- em favor de complexos que amontoam o maior número de casas individuais por área. Esta atitude simplesmente perpetua uma cidade espalhada e de baixa densidade, insustentável do ponto de vista ambiental".
}

tecnologias modernas ecológicas às técnicas antigas" (Pinheiro, 2002 apud Villela, 2007, p. 66). Essa arquitetura tem origens na Arquitetura Vernacular.

Nos anos 1960 surgiu a expressão projeto bioclimático através dos irmãos Olgyay que aplicavam os conceitos do estudo do clima para projetos de conforto nos edifícios. A Arquitetura Bioclimática pensa no ambiente local e, sobretudo, em seu clima, na tentativa de que o projeto alcance uma melhoria do conforto térmico projetual. As estratégias integradas propostas pelos irmãos para a construção de uma edificação climaticamente equilibrada eram: clima, biologia, tecnologia e arquitetura. As ideias da Arquitetura Bioclimática evoluíram e, nos anos de 1980, compuseram as ideias da Arquitetura Verde, green building, que compreendia que a integração com a natureza era o ponto chave da arquitetura e que os materiais construtivos deveriam ter uma preocupação especial, assim como os resíduos gerados pela construção em si (Villela, 2007).

45 Arquitetura Vernacular emprega recursos, técnicas e materiais regionais, do próprio ambiente onde a edificação é construída, tendo, assim, um caráter local. Nesse tipo de arquitetura os conhecimentos construtivos são transmitidos através das gerações e alguns dos materiais usados são, por exemplo, o adobe, o bambu e o pau-a-pique. 


\section{A Arquitetura Sustentável possivelmente associa as} características da Arquitetura Bioclimática e da Arquitetura Ecológica, unindo-as aos novos conceitos de sustentabilidade.

O conceito apresentado por Brundtland sobre desenvolvimento sustentável permitiu muitas interpretações e subdefinições que poderiam ser interpretadas em áreas específicas. A primeira proposta de projeto e construção foi elaborada pelo arquiteto inglês Norman Foster: "criação de edificações eficientes do ponto de vista energético, saudáveis, confortáveis" e com longa vida útil. A segunda proposta foi feita pela Building Services Research and Information Association ${ }^{46}$ que "define a construção sustentável como a 'criação e gestão de edifícios saudáveis, baseados em princípios ecológicos e no uso eficiente dos recursos'"' (Xavier, 2011, p. 41).

Kibert (2008 apud Xavier, 2011) apresenta os princípios para a construção sustentável:

"1) redução dos recursos consumidos; 2) reuso de recursos; 3) uso de recursos recicláveis; 4) proteção da natureza; 5) eliminação de resíduos tóxicos; 6) aplicar

${ }^{46}$ A Building Services Research and Information Association é uma associação britânica sem fins lucrativos e membro do Conselho da Indústria da Construção que realiza testes, pesquisas e consultorias, além de oferecer serviços especializados em construção e serviços de Engenharia (Fonte: a noção de ciclo de vida; 7) foco na qualidade. Ao apresentar uma proposta de moradia mais sustentável - Protótipo da Casa Alvorada, Sattler (2007b) apresenta diretrizes relacionadas a projetos sustentáveis, entre elas: 1) dimensionamento dos espaços conforme acessibilidade universal; 2) adequação climática por meio de implantação, posicionamento das aberturas, pé-direito variável, pergolado e vegetação caducifólia; 3) adoção de sistema de captação e aproveitamento de águas; 4) implantação de sistema local de tratamento de águas residuais; 5) instalação de coletor solar experimental 6) instalação de aquecedor, que utiliza biomassa como fonte energética; 7) especificação de materiais segundo critérios de origem (preferência por materiais produzidos a uma distância máxima de $100 \mathrm{~km}$ do local de construção); 8) especificação de materiais que não contivessem compostos orgânicos voláteis (VOCs) ou fibras que apresentassem risco à saúde; e 9) reutilização de materiais oriundos de construção abandonada existente no terreno"

Uma residência pode, por exemplo, ter sido construída seguindo as recomendações ambientais na tentativa de ser sustentável mas deixa de se enquadrar nesse quesito por ter usado material construtivo produzido por trabalho infantil, falhando na questão da sustentabilidade social ${ }^{47}$.

https://en.wikipedia.org/wiki/BSRIA, acessado dia 26 de agosto de 2015, as 15:11 hrs).

${ }^{47}$ A sustentabilidade social deve ser avaliada pela responsabilidade social, recursos humanos, projetos sociais e por auxiliar o crescimento da comunidade; essa vertente sustentável mostra-se muito frágil na construção civil, sobretudo na 
Atualmente os aspectos ambientais, green, têm uma maior repercussão tanto na mídia quanto em estratégias de marketing, fato muito preocupante em um país com os problemas sociais e econômicos como o Brasil (Agopyan e John, 2011).

A sustentabilidade potencialmente remete à uma boa arquitetura pois engloba muito mais do que apenas o edifício, além de abranger a cidade, seu crescimento e sua infraestrutura.

O desempenho ambiental dos edifícios também envolve os impactos gerados na natureza ao se realizar a construção em si; para avaliar esse quesito é preciso qualificar o edifício quanto ao consumo de energia, a quantia de emissão de gases de efeito estufa, a adaptação climática, a eficiência energética, a orientação solar e dos ventos em relação ao prédio, a oferta de bicicletários, a oferta de estações para a recarga de carros elétricos, a reciclagem dos resíduos da construção e até os subsídios para o incentivo de uso do transporte público, todos esses são fatores abordados para a avaliação do desempenho ambiental de um prédio.

condição de seus empregados. Esse fato precisa ser cuidadosamente verificado pelos arquitetos. Já no quesito econômico a sustentabilidade pode ser empregada dentro da construção civil ao se otimizar recursos para evitar desperdícios, mas se
Agopyan e John (2011) propõe uma adaptação da Agenda 21 para o cenário brasileiro levando em conta os seguintes tópicos: 1) a qualidade do ar interno; 2) a avaliação ambiental das construções com base em seu ciclo de vida; 3) o uso de materiais ambientalmente saudáveis; 4) a poluição nos canteiros de obras e indústrias; 5) a diminuição do desperdício e a realização da manutenção dos resíduos; 6) a reciclagem dos resíduos das construções e das demolições e o aumento do uso de materiais recicláveis nas construções; 7) o uso racional da água, da energia e o aumento da eficiência energética; 8) o uso de tecnologias de conservação energética; 9) o aumento da durabilidade das construções e a realização de um planejamento para as manutenções; 10) a melhoria da qualidade da construção; 11) o gerenciamento e a organização dos processos; 12) a criação de uma agenda social para a resolução do problema do déficit habitacional, da infraestrutura e dos serviços sanitários.

A Arquitetura Sustentável deve caminhar em harmonia com o projeto, a tecnologia, a economia, a cultura, a sociedade e,

forem reunidas as medidas ambientais e sociais o preço final da construção será reduzido. 
principalmente, com seu entorno criando projetos que sejam sensíveis à cultura e ao clima do local. Segundo Ingersoll (2003 apud Xavier, 2011) as intervenções urbanas são fundamentais para a Sustentabilidade; também é importante pensar nas escalas urbanas que adequem e possibilitem uma mobilidade urbana que impacte pouco ou quase nada no meio como caminhadas e pedaladas. Sem esses fundamentos discutidos no ensino superior não é possível a abordagem efetiva e soluções para os problemas da Arquitetura Sustentável.

A preocupação com o planeta, seu meio ambiente e clima deve estar sempre em harmonia com as tradições culturais, a disponibilidade de recursos e materiais, a redução de desperdícios e com a conservação de energia, esses são fatores essenciais para o desenvolvimento e planejamento de projetos arquitetônicos e urbanos que se preocupem não só com o bem-estar do usuário, mas com as abrangências sustentáveis no geral.

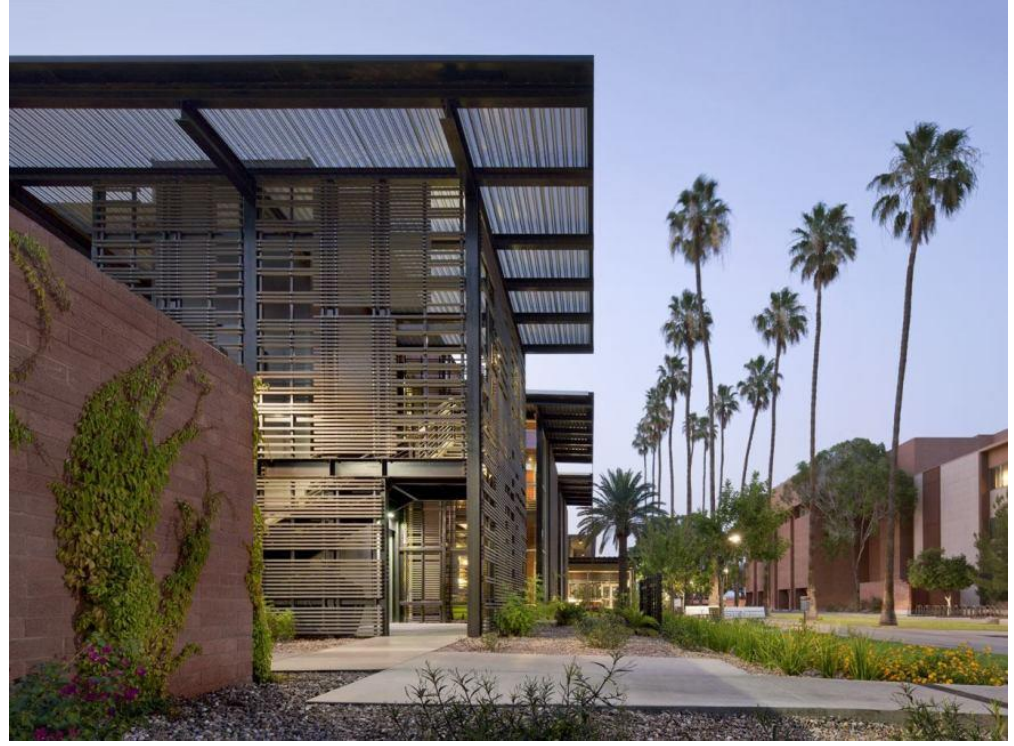

Figura 10- Edifício do Centro Médico Universitário da Universidade do Estado do Arizonas, EUA, tem a certificação LEED Platina, 2012, projeto de Lake|Flato Architects and Orcutt|Winslow.

(Fonte: http://www.ecobuildingpulse.com/projects/2014-aia-cote-topten-winner-arizona-state-university-student-health-services-building_o, acessado dia 26 de agosto de 2015, as 17:45 horas). 


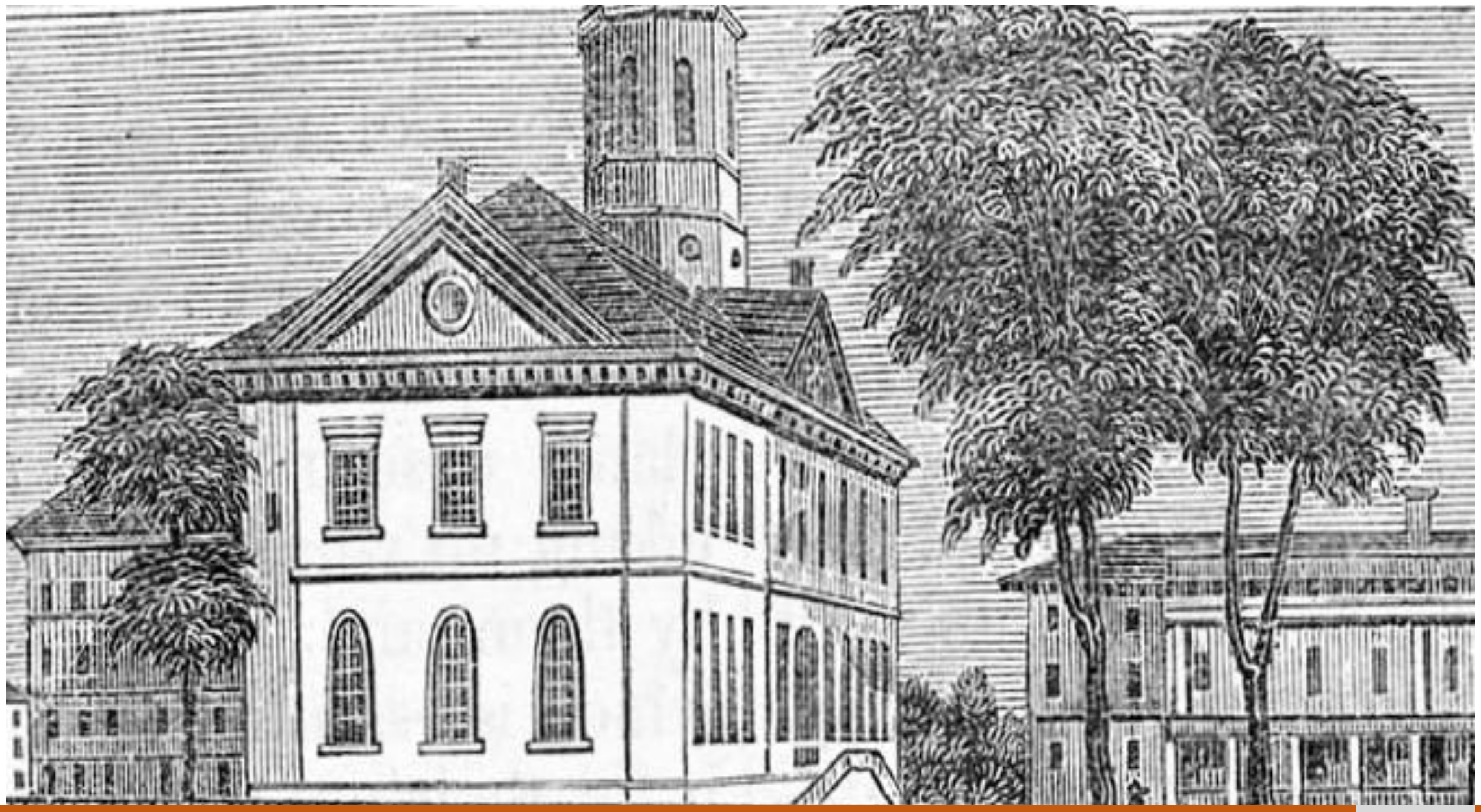

\author{
HISTÓRIA DAS UNIVERSIDADES: ORIGENS E DESENVOLVIMENTO 3
}

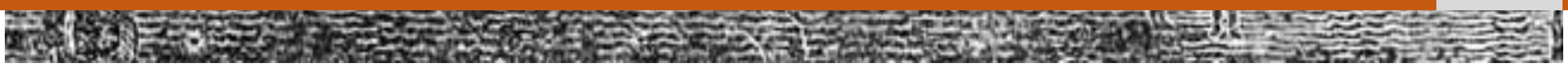


Universidade de Harvard, fundada nos Estados Unidos em 1636, a mais antiga instituição de ensino superior das Américas. Fonte da imagem: https://college.harvard.edu/about/history (acessado dia 19 de junho de 2016, as 22:44 horas). Editada pela autora. 


\section{HISTÓRIA DAS UNIVERSIDADES: ORIGENS E DESENVOLVIMENTO}

A palavra universidade surgiu de universitas, ou seja, corporação. Segundo Salomão (2011), no século XII a organização de instituições superiores era chamada de Studium Generale, Estudos Gerais, e no século subsequente, Universitas Magistrorum et Scolarium ou Universitas Studii. Verger (1990, p. 48) explica a diferença semântica entre os termos: sendo o studium o espaço onde ocorria o ensino superior e universitas era a organização que possibilitava o funcionamento e independência do studium.

Para Charle e Verger (1996, p. 07-08), universidade também pode ser comparada a uma comunidade, autônoma ou não, de mestres e aprendizes que se reuniam em busca de um aprendizado de nível superior; esse modelo existe até os dias atuais e espalhados por todos os continentes.

Os autores falam que a universidade se desenvolveu por séculos e por isso uma definição mais precisa do termo acaba sendo impossível.

\subsection{O início: o modelo clássico e o domínio islâmico}

Alguns historiadores marcam que as universidades se iniciaram na Grécia Antiga e que, inclusive, anteciparam a estrutura espacial da instituição.

Ribeiro, A. (2008, p. 20) afirma que na Grécia o ensino possuiu um lugar de destaque, as primeiras escolas, propriamente ditas, teriam sido fundadas no século IV a. C. por Sócrates, em 393 a. C. e por Platão, em 387 a. C.; este último teria fundado uma Academia porem não era uma instituição e nem um espaço de ensino, as lições eram dadas "nos passeios do jardim de Academo".

$\mathrm{Na}$ Antiguidade os professores eram denominados sábios, escribas e doutores da lei pois eram eles quem sabiam ler e escrever; existiam também os preceptores, que eram pagos e que lecionavam nas casas:

“(..) Sócrates, os sofistas e os preceptores (...) ensinavam nas residências, nos jardins e até nas praças. O filósofo Platão foi praticamente o primeiro a 
criar uma instituição de ensino. No século III a. C. em Atenas, Platão fundou uma escola, que ele denominou de academia, em homenagem ao herói grego Academo (...). Na academia, além da Dialética, que é a arte do diálogo, ensino esse que Platão herdou de Sócrates - seu mestre - era ensinado também, a Geometria, a Política, a Metafísica e a Ginástica. Platão teve a preocupação de preparar seus sucessores, a fim de que, após a sua morte a academia não viesse fechar as suas portas". (Alves, 2014, p.01 apud Mahler, 2015, p. 35).

O ensino ocorria na Grécia Clássica através da Academia e também de Liceus ${ }^{48}$ e seguiu ocorrendo, também, durante o domínio romano. Existiam escolas espalhadas por cidades como Beirute, Gaza, Atenas e Alexandria.

Essas escolas foram importantes para suprir a demanda profissional gerada, no século IV, pela grande quantidade de serviço público romano.

\footnotetext{
48 Lykeion, Liceu, "era um gymnasion perto de Atenas". Alguns cursos lecionados nos liceus eram voltados para um restrito público que já tinha conhecimentos
}

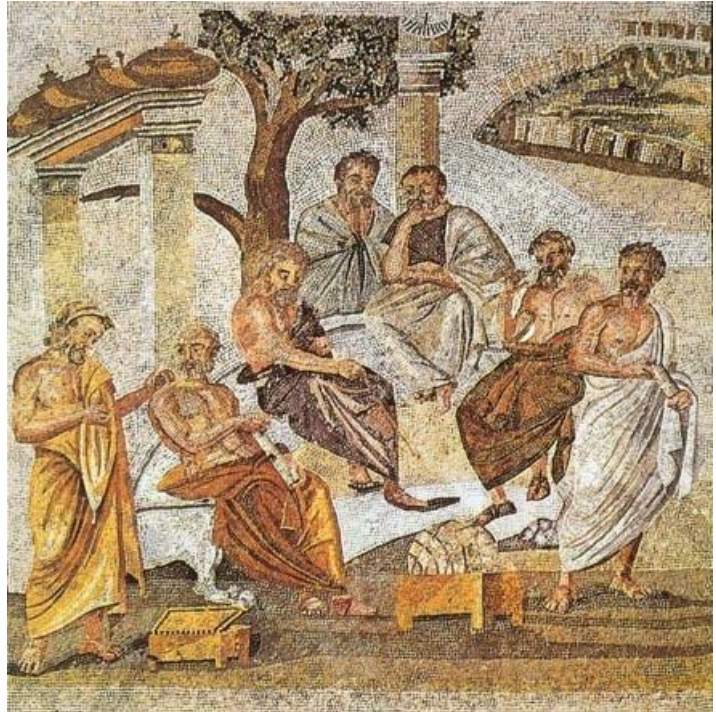

Figura 11- A Academia de Platão, mosaico localizado em Pompéia. (Fonte: https://pt.wikipedia.org/wiki/Academia_de_Plat\%C3\%A3o, acessado dia 19 de junho de 2016, as 19:36 horas).

Com a queda do Império Romano ocorreu com o passar do tempo a diminuição do ensino da escrita e leitura que só foi retomado com o Humanismo e no período da Renascença. Na Idade Média, além da decadência do conhecimento científico, houve também o da sociedade urbana e das escolas. Inicialmente as escolas eram vinculadas à Igreja, ou seja, o ensino era religioso, e a ciência antiga acabou sendo considerada pagã e deixada de lado.

sobre Lógica, Física e Metafísica e outros eram de mais fácil acesso como Retórica, Política e Literatura (Mehler, 2015, p. 37). 
A filosofia permaneceu presente em Atenas e em Alexandria mesmo após a queda do Império Romano; em Alexandria funcionava o Museum, um espaço semelhante às universidades e voltado à pesquisa.

Goody (2015) fala, a partir da leitura e exposições de distintos pesquisadores como Browning (2012), Conrad (2000), Kristeller (1945), Makdisi (1964) e Reynolds e Wilson (1974), sobre apropriações realizadas pela sociedade ocidental no decorrer da história. Entre diversos temas, fala sobre a apropriação das origens das instituições universitárias; segundo o autor, acredita-se, através de uma visão bastante eurocêntrica, que o ensino superior se deu com a criação das universidades europeias, inicialmente pela de Bolonha no século $\mathrm{XII}^{49}$. Contudo, o domínio Islâmico, até cerca de 732 a. C., estendia-se do sul da Espanha ao norte da China e da Índia e ao sudoeste da Ásia; por esta razão os conhecimentos e as invenções eram difundidos com facilidade por toda as áreas

\footnotetext{
${ }^{49}$ É apresentada também a visão de Haskin (1923 apud Goody, 2015, p. 245) em que o pesquisador fala sobre o fato das universidades terem sofrido influências islâmicas no século XII.

${ }^{50}$ Essas instituições, segundo o autor, eram responsáveis pelas bibliotecas, dãr al'ilm, com o intuito de retomar o ensino, porem de uma maneira religiosa. Apesar de voltada para a religião, essa instituição era aberta para o ensino de ciências
}

conquistadas. Foram os árabes, por exemplo, que levaram ao Ocidente os textos clássicos que contribuíram para a volta do ensino no Ocidente no final da Idade Média.

Apesar das universidades do ocidente serem distintas das madrasah ${ }^{50}$ muçulmanas dos séculos $\mathrm{X}$ e $\mathrm{XI}$, há muitas semelhanças entre elas já que a faculdade como um espaço beneficente tem, então, sua origem do islâmico waqf $f^{51}$, ou seja, do "sistema de doação de terras com propósito religioso e de caridade" ${ }^{25}$.

No século X, foi criada em Bagdá a masjid-khan, estalagem, que abrigava alunos que se mudavam para poderem estudar; a masjid-khan também contribuiu para a mudança curricular da madrasah. Goody (2015, p. 261-262) lista as semelhanças entre o ensino superior no Oriente e no Ocidente:

"(1) o waqf e a instituição de caridade (...) o fundador estabelece sua entidade por livre e espontânea vontade, sem a mediação do governo central ou da Igreja; (2) a madrasah e a faculdade baseadas nas leis da waqf ou da instituição de caridade, com seus

estrangeiras como persa, grega, indiana e chinesa, que eram aprendidas também em tribunais e instituições médicas.

${ }^{51}$ Apesar da origem do ensino islâmico ter sido por financiamento privado, as instituições em si só existiram com o estabelecimento caridoso da waqf, ou seja de instituições beneficentes existentes por lei a partir do século $X$.

${ }^{52}$ A universidade de Paris, por exemplo, foi fundada em 1138 por um peregrino de Jerusalém, talvez sob influência da madrasah (Goody, 2015, p. 259). 
quadros de graduados e alunos de graduação (...) e outros elementos correspondentes dessas instituições, entre outras coisas, as obras dos fundadores (...); (3) a vontade soberana de criar universidades no Islã Ocidental, na Espanha cristã e no sul da Itália; (4) o desenvolvimento de duas dialéticas, uma legal, a outra especulativa; (5) a controvérsia na base dos estudos legais e teológicos; (6) o status único do professor mudarris al-figh (professor de jurisprudência) na madrasah e o equivalente nas universidades do sul da Europa, começando por Bolonha; (7) a aula inaugural (dars iftitahi) e o inceptio; (8) o um'id e o tutor; (9) o shahid e o notário (...); (10) o khadim e o estudante servidor; (11) o lectio e os dois conjuntos de três significados idênticos de qara'a e legere; (12) o ta'liqa e o reportatio; (13) o resumo (...); (14) o interesse pela comprovação (...); (15) a subordinação das artes literárias às três faculdades superiores- Direito, Teologia e Medicina- provocada por uma franca concentração na dialética e na controvérsia" (Makdisi, 1981 apud Goody, 2015, p. 261- 262).

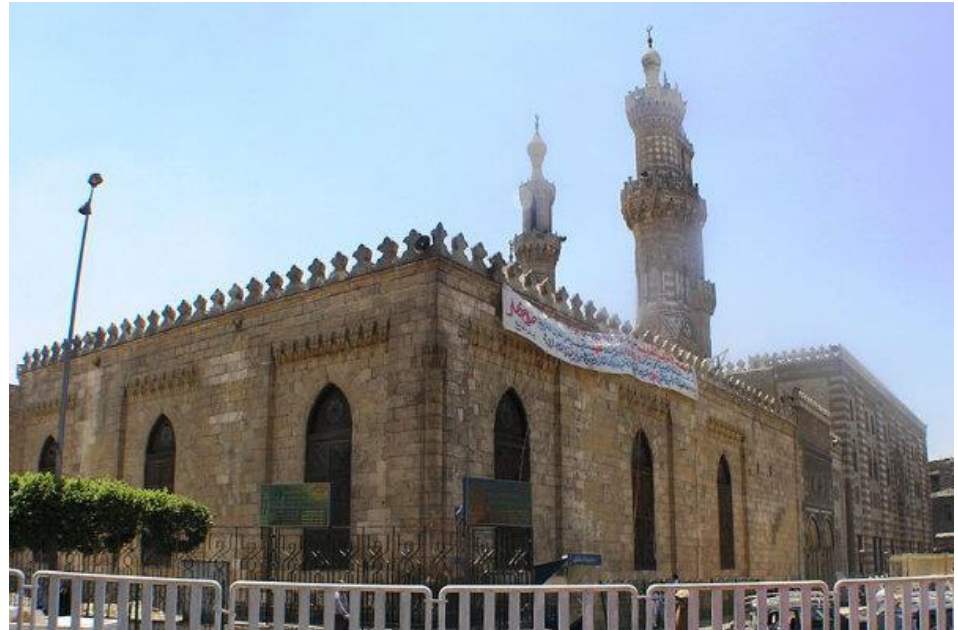

Figura 12- Universidade Al-Azhar, no Egito, fundada entre 970 e 972 a. C. É considerada a segunda universidade mais antiga do mundo que ainda está em funcionamento.

(Fonte: http://revistagalileu.globo.com/Revista/Common/0,,EMI34390417770,00-AS+UNIVERSIDADES+MAIS+ANTIGAS+DO+MUNDO.html, acessado dia 20 de junho de 2016, as 22:24 horas).

No Ocidente, no século VII, as escolas deixaram de fazer parte das cidades e a Igreja e os senhores feudais começaram a exercer um papel importante na sociedade, o ensino passou a ser exclusivo para poucas famílias da elite e era ministrado por tutores particulares. Já no Oriente, o conhecimento seguiu através de traduções de textos clássicos, poesias e até trechos bíblicos para as línguas orientais (Goody, 2015, p. 254) 
Esses modelos vindos do Oriente são as origens de como, atualmente, é conhecida a academia ${ }^{53}$.

Segundo Makdisi (1981 apud Goody, 2015, p. 259), a universidade só surgiu no Ocidente Cristão no século XII.

Apesar da igreja católica ter fechado as instituições antigas de ensino para restringir a divulgação do ensino, ela acabou criando uma maneira própria de ensinar, mesmo sendo o ensino superior clássico considerado pagão. No final do século $\mathrm{VI}$ a redução do ensino foi intensa (Goody, 2015).

Na Europa ${ }^{54}$, as escolas eclesiásticas e as dos mosteiros ${ }^{55}$ voltaram a realizar algumas atividades semelhantes às de universidades, esse é o marco para o que se tornará, nos séculos XI e XII, a Universidade de Bolonha. Com as novas instituições de ensino o conhecimento, então, passa a ser difundido de maneira mais rápida no Ocidente do que no Oriente.

O humanismo e a Reforma na Europa fragilizaram a grande influência da Igreja, sobretudo através do ensino da literatura e da

53 Não há dúvidas de que a cultura islâmica teve significativas e influentes instituições de ensino superior, a diferença principal dessas para as ocidentais é que enquanto as primeiras foram sempre quase que voltadas para a religião, na Europa se iniciou assim, mas com o tempo outras disciplinas foram desenvolvidas nesses espaços. escrita que passou a não ser mais realizado exclusivamente por religiosos. A importância dessa desvinculação foi a liberdade de estudar e questionar, dentro da instituição de ensino superior, distintas e importantes áreas (Goody, 2015).

"Na Europa, essas instituições, que emergiram no século XII, foram chamadas universidades. Esse movimento foi parte de um renascimento geral da educação na Europa ocidental (onde o letramento havia decaído significativamente). Historiadores ocidentais consideraram com frequência as universidades, os reais precursores da educação superior, relacionadas ao nascimento independente do humanismo e inerentes a ele; mas, na verdade, elas ainda estavam claramente ligadas à Igreja e ao treinamento de 'clérigos', como era o caso da madrasah no islamismo. Entretanto, tiveram, sim grande importância para a Europa e sua modernização, sobretudo quando desenvolveram uma perspectiva mais humanista e abandonaram alguns de seus papéis religiosos" (Goody, 2015, p. 267).

${ }^{54}$ As religiões dominaram e oprimiram o ensino e a maneira de se ensinar. $\mathrm{Na}$ Europa, segundo Goody (2015), a desvinculação dessas duas instituições teve origem no humanismo do século XII ao XV, com muitas influências islâmicas.

${ }^{55}$ Segundo Mehler (2015), os mosteiros eram os espaços onde eram realizadas as atividades de ensino, antes da formação superior. 


\subsection{Do medievo à expansão pela Europa}

Na Europa Ocidental na Idade Média, existiam nas pequenas cidades medievais ${ }^{56}$ corporações de ofício, também conhecidas como guildas, que eram espaços de produção onde ensinamentos eram passados do mestre para o aprendiz. Nas guildas o futuro artesão ficava hospedado e alimentado durante o período pré-estabelecido para seu aprendizado (Pinto e Buffa, 2009).

As corporações também acabavam sendo um espaço de proteção, segundo Cambi (1999, p. 175) o ensino neste espaço era organizado a partir de fundamentos técnicos e ético-sociais que eram aprendidos pela aquisição de conhecimentos e pela vida do aluno dentro da corporação, o que acabava formando o comportamento social e individual. Ainda segundo o autor, a importância das corporações também era educar, além da ética religiosa, de uma forma mais "laica, técnica, racionalista".

Pinto e Buffa (2009, p. 23) afirmam que o desenvolvendo das cidades, das relações comerciais e da cultura do século XII, assim como o enfraquecimento do poder da Igreja e a criação de escolas para disseminar o conhecimento de escrita, leitura e cálculo contribuíram para que mestres pudessem se organizar em corporações, livres de influências dos senhores feudais e da Igreja, para ministrarem suas lições em qualquer local em troca de "salários ou taxas pagas pelos estudantes". É importante ressaltar o fato de que essas aulas não ocorriam em prédios voltados para este propósito, normalmente ocorriam na casa do mestre ou em algum local alugado ${ }^{57}$

mestres e estudantes que se realiza em qualquer lugar com a vontade e o objetivo de aprender as ciências".

57 Ainda segundo Pinto e Buffa (2009), as casas desse período eram diferentes das que conhecemos hoje, assim como é recente o conceito de privacidade; as salas de aula além de possuírem pouca iluminação, ventilação e conforto térmico, dividiam as atividades de aula com outras atividades que ocorriam no local e, algumas vezes, esse espaço era até mesmo compartilhado com depósitos e estábulos. 
Nas primeiras universidades medievais ${ }^{58}$ os alunos eram dispostos frente a frente e o professor, em destaque, ficava ao fundo, permitindo que os alunos ouvissem bem e discutissem. A separação entre as salas não possuía uma diferenciação em relação à idade e ao nível de conhecimento dos alunos, todos os aprendizes assistiam as mesmas aulas de acordo com seus desejos de aprendizado e condições de se manterem estudando (Pinto e Buffa, 2009, p. 25):

Verger (1990), afirma que, conforme se ampliou a quantidade de alunos, foi também necessário rever a organização espacial que conseguisse atender essa nova demanda: os espaços acabaram sendo reformados ou ampliados, gerando espaços precários.

Segundo Salomão (2011), muitas escolas medievais foram desaparecendo a partir do século XII, enquanto algumas como a de Paris, Bolonha e Oxford tiveram um rápido desenvolvimento. As universidades de Paris e Oxford eram compostas por associações de

${ }^{58}$ Charle e Verger (1996, p.13) falam que antes das guildas já existiam escolas de artes-liberais que dependiam de autorização do papado para poderem iniciar suas atividades. Durante o século XII foram criadas faculdades a partir de escolas para atender a demanda da sociedade e da Igreja; a Igreja compreendeu nesse momento que era preciso institucionalizar o ensino para continuar dominando-o, assim uma universidade só poderia ser aberta com a Licentia ubique docendi, emitido pelo próprio pontificado (Ullmann, 2000, p. 105). mestres com uma forte presença eclesiástica, já as universidades mediterrâneas eram compostas por associações estudantis ${ }^{59}$ :

"em Paris, mestres e estudantes compunham a universidade, mas toda a iniciativa pertencia aos primeiros (...). Em Bolonha, em contrapartida, eram os estudantes que formavam a universidade (...) isso significava não somente que os próprios estudantes asseguravam o funcionamento da universidade, mas também, que recrutavam os professores e exerciam um controle constante sobre o valor e a regularidade de seu ensino e mesmo de sua vida privada" (Verger, 1990, p. 48).

Segundo Verger ${ }^{60}$ (1990), são definidas as seguintes origens para as Universidades medievais: (a) Universidades que foram criadas espontaneamente a partir do desenvolvimento de escolas que já existiam, como ocorreu em Paris, Bolonha e Oxford; (b) Universidades que surgiram a partir de movimentos migratórios de alunos e mestres, como a de Cambridge que recebeu alunos e professores vindos da França, entre 1229-1231, pela secessão parisiense ${ }^{61}$; (c)

${ }^{59}$ Por essa razão, segundo Verger (1990), não é possível compreender as origens das universidades sem que, antes, sejam compreendidas as questões sociais que ocorreram na Idade Média. O autor cita como exemplo as disputas entre os poderes laico e eclesiástico.

${ }^{60}$ Para Ullmann (2000) uma universidade medieval poderia ser considerada como o ensino, de pelo menos uma faculdade, e formada por grupos de alunos.

${ }^{61}$ As universidades que surgiram por secessão nasceram como resultado das disputas entre autoridades do local e homens do saber, que buscavam um local 
Universidades que foram criadas a partir de relações entre os homens do saber e o poder, laico ou não, essas universidades eram fundadas por figuras como o Papa ou o imperador e, desde sua fundação, já tinham estatutos, como ocorreu na Universidade de Nápoles.

A Universidade de Bolonha é considerada a primeira das universidades ocidentais, ela nasceu a partir da escola de Direito e tinha, desde 1158, a proteção do imperador. A partir de 1190 os alunos se organizaram em citramontanos, de origem como da Itália, e em untramontanos, vindos da França, Espanha, Alemanha e Inglaterra, ou seja, em nações ${ }^{62}$, cuja união derivou na composição da Universidade de Bolonha (Ullmann, 2000) ${ }^{63}$.

Mesmo que as datas do início do funcionamento das atividades das universidades nem sempre sejam exatas, alguns historiadores concordam com a tabela 2.

com proteção e aceitação da população (Verger, 1990). Charle e Verger (1996, p. 18) falam que conflitos internos ou com autoridades contribuíram para a migração de mestres e alunos, "assim, novas universidades nasceram por desmembramento, mas somente duas delas mostraram-se duráveis: Cambridge, desde 1209, nascia de uma migração oxfordiana; Pádua, fundada em 1222 pelos doutores e estudantes foragidos de Bolonha".

62 Ullmann (2000) também afirma que, as universidades ocidentais receberam grande quantidade de estudantes de distintas nacionalidades e os próprios alunos

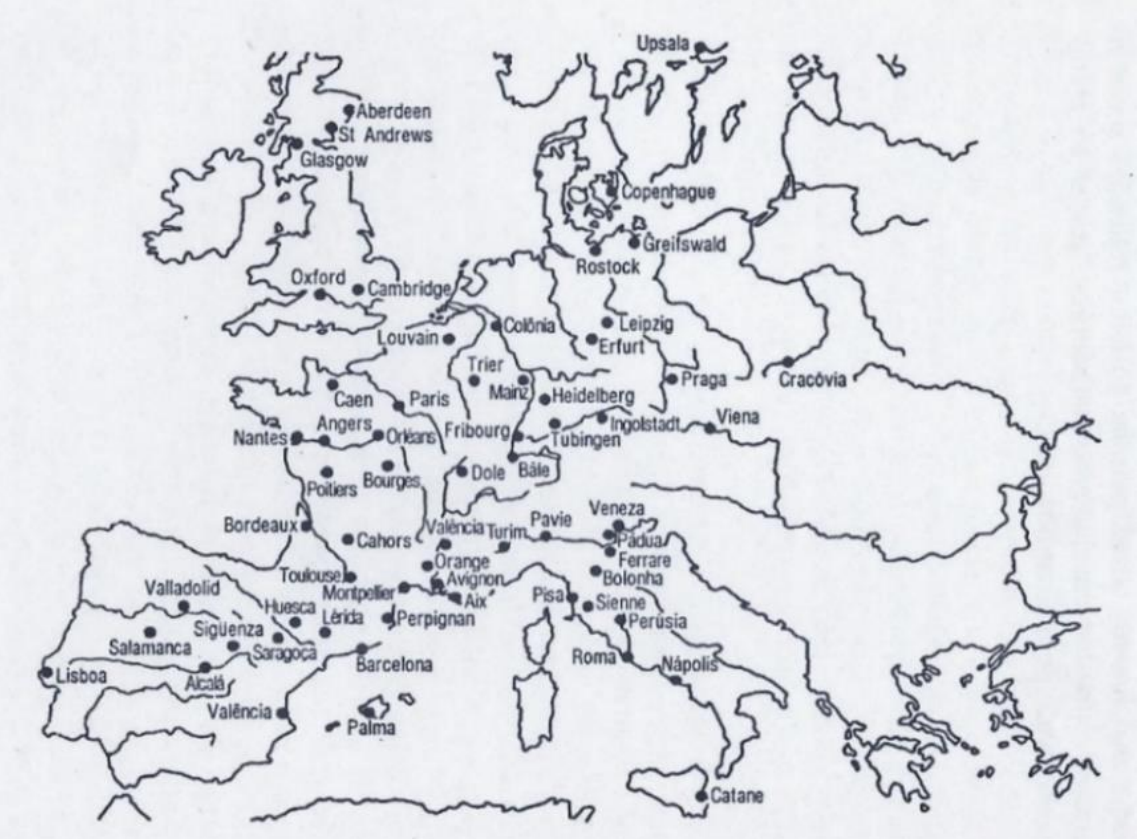

Figura 13- Localização das universidades em 1500. (Fonte: Charle e Verger, 1996. p. 10).

se organizaram em nações com o intuito de protegerem seus privilégios, essas organizações auxiliavam mestres e alunos das mesmas regiões. Isto ocorreu em cada universidade, na de Paris, por exemplo, os alunos se organizaram em quatro grupos de acordo com suas origens regionais.

${ }^{63}$ Pode-se considerar, segundo Charle e Verger (1996, p.13), as universidades de Bolonha, Paris e Oxford como, praticamente, contemporâneas por sua estrutura e sua importância social e intelectual. 


\begin{tabular}{|c|c|}
\hline Ano de Fundação & Universidade \\
\hline 1088 & Universidade de Bolonha, Itália \\
\hline 1150 & Universidade de Paris, França \\
\hline 1167 & Universidade de Oxford, Inglaterra \\
\hline 1209 & Universidade de Cambridge, Inglaterra \\
\hline 1218 & Universidade de Salamanca, Espanha \\
\hline 1222 & Universidade de Pádua, Itália \\
\hline 1224 & Universidade de Nápoles, Itália \\
\hline 1240 & Universidade de Siena, Itália \\
\hline 1241 & Universidade de Valladolid, Espanha \\
\hline 1290 & Universidade de Coimbra, Portugal \\
\hline 1303 & Universidade de Roma, Itália \\
\hline 1308 & Universidade de Perugia, Itália \\
\hline 1321 & Universidade de Florença, Itália \\
\hline 1343 & Universidade de Pisa, Itália \\
\hline 1348 & Universidade de Praga, República Tcheca \\
\hline 1361 & Universidade de Pavia, Itália \\
\hline 1364 & Academia Cracow, Polônia \\
\hline 1365 & Universidade de Viena, Áustria \\
\hline 1385 & Universidade de Heidelberg, Alemanha \\
\hline
\end{tabular}

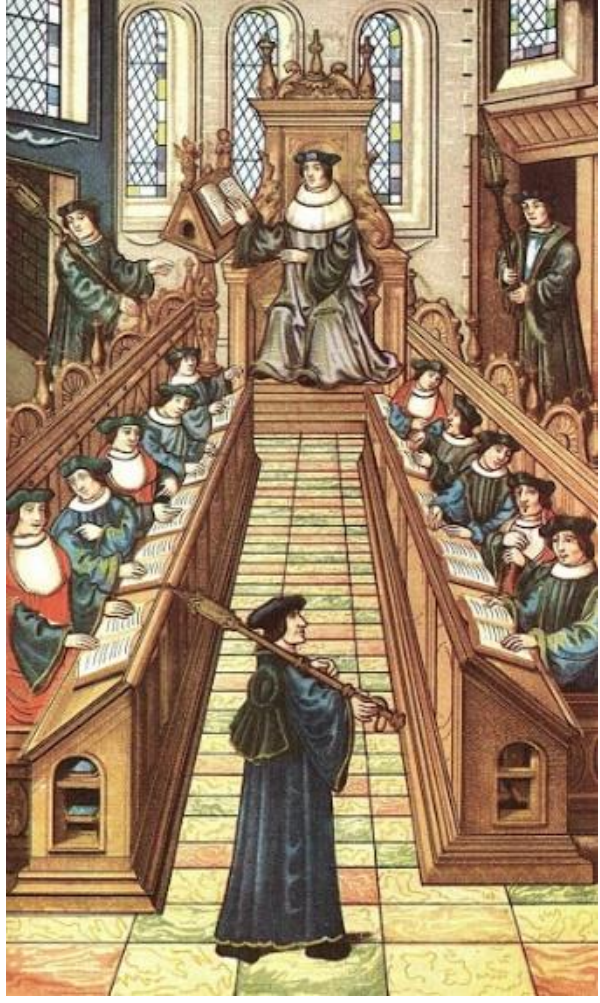

Figura 14- Mestres e aprendizes no século XIII. (Fonte: http://ipco.org.br/ipco/wp-

content/uploads/2013/08/Reuni\%C3\%B3n-de-los-doctores-de-la-UniversidadParis.jpg, acessado dia 06 de junho de 2016, as 16:08 horas).

Tabela 2- Cronologia das universidades na Europa Ocidental. (Fonte: Coulson, Roberts e Taylor, 2010, p. 02). 
Conforme cresciam as cidades ${ }^{64}$, mais aumentava as distâncias entre moradias, comércios e serviços, que nesse momento já se encontravam espalhados pelo tecido urbano, o que contribuiu para que os mestres passassem a lecionar nas próprias habitações dos alunos; com o tempo essas habitações passaram a contar com instalações de salas de aulas independentes. Essas habitações ou hospedarias foram o início do colégio medieval que no decorrer do tempo passaram a ser anexos das universidades (Pinto e Buffa, 2009).

Foi com o tempo que a noção de universidade foi sendo construída, primeiro com a Igreja e, depois, com a Reforma. Na Revolução Francesa as universidades foram impugnadas por ter relação com a Igreja e o governo. Independente disto, a ideia de universidade só ganhou força e representatividade com os espaços construídos.

Em Paris, a partir do ano de 1200, os mestres independentes se uniram e, apesar do imperador não ter se oposto, o bispo tentou

\footnotetext{
${ }^{64}$ Também aumentou a quantidade de universitas conforme aumentava 0 tamanho da cidade e, no século $\mathrm{XV}$, as administrações obrigaram os aprendizes que não fossem de origem nobre a se matricularem nas hospitia, que eram habitações onde os aprendizes tinham que morar até o final de seus estudos, de acordo com suas rendas, assim era possível controlar a quantidade de estudantes e a consequente questão habitacional. Com o crescimento urbano aumentou também a quantidade de comércio e, também, a necessidade de mais mão de
}

dificultar essa movimentação gerando distintos conflitos, mas, em 1215, o papa outorgou os primeiros estatutos das universitas magistrorum er scolarium Parisiensium, ou seja, a autonomia do que seria a universidade parisiense ${ }^{65}$ (Charle e Verger, 1996).

"A escola da Catedral de Notre- Dame foi fundada por volta de 1170. Quando o número crescente de estudantes fez com que se tornasse insuficiente para abriga-los, os professores particulares foram autorizados a abrir escolas. Estes mestres se reuniram formando sua corporação, uma universitas, à semelhança dos modernos sindicatos" (Mahler, 2015, p. 41-42).

Segundo Turner (1995), as universidades britânicas de Oxford e Cambridge, cujas origens datam respectivamente os séculos XII e XIII, foram moldadas a partir do currículo e dos métodos de ensino da Universidade de Paris, ou seja, os alunos escolhiam seus mestres e passavam a morar nas residências dos moradores locais. Existiram também os halls e hostels, casas alugadas por alunos com supervisão

obra; consequentemente mais mestres chegavam e fundavam novas salas de aula, aumentando ainda mais a quantidade de alunos (Pinto e Buffa, 2009).

${ }^{65}$ No século XVI e XVII essa universidade era um "aglomerado de colégios, à semelhança das universidades inglesas. Os colégios foram inicialmente pensionatos de estudantes, aos quais se acrescentaram depois salas de aula" (Mahler, 2015, p. 41). 
ou não de algum mestre, e, depois, surgiram os Colleges ${ }^{66}$, um espaço permanente voltado para alunos de baixa renda graduados ou não. Com as transformações de cunho político e religioso geradas pela Reforma, no século XVII, os currículos das instituições britânicas foram modificados, aumentando também a procura por esses ensinos:

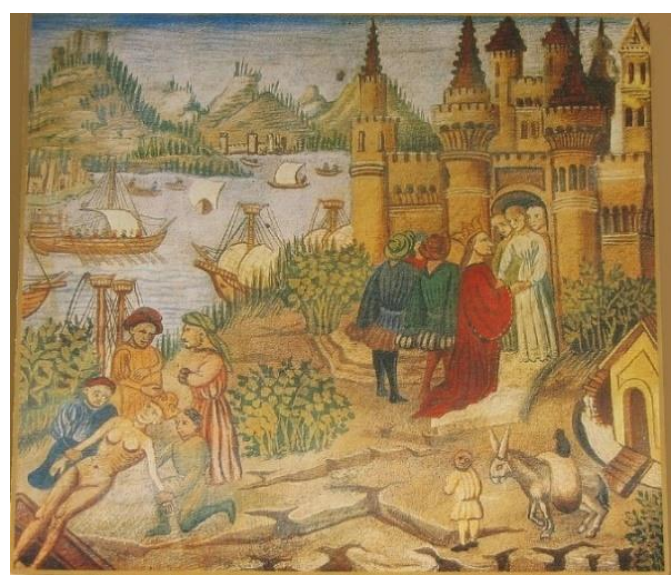

Figura 15- Representação da Escola Médica de Salerno, século XI.

$$
\text { (Fonte: }
$$

https://pt.wikipedia.org/wiki/Escola_M\%C3\%A9dica_Salernitana\#/media/File:Scuo laMedicaMiniatura.jpg, acessado dia 20 de junho de 2016, as 22:18 horas).

\footnotetext{
${ }^{66}$ Pinto e Buffa (2009, p. 35) apresentam a diferenciação entre collèges franceses e Colleges britânicos e estadunidenses: "na França, o collège faz parte do ensino secundário clássico- humanista. (...) na Inglaterra, o college pertence ao ensino superior: é a parte da universidade que prepara os estudantes (undergraduate) para a obtenção de títulos conferidos pelas universidades. O college inglês (...) prepara os estudantes para a universidade (...). Nos colleges, os estudantes têm à
}

No século XVI, Cambridge já inovava em sua configuração espacial com pátios "que faceavam a cidade, num dos lados, através de um muro, afastando-se da tradição monástica medieval" (Ribeiro, A., 2008, p. 30).

Diferente da Inglaterra, que possuía universidades centralizadas, a Escócia contava com quatro pequenas instituições que fundiram os Colleges e a university 67: Andrews, Glasgow, Aberdeen e Edimburgo (Turner, 1995).

Oxford, Cambridge e as universidades da Escócia foram modelos importantes para os Colleges que iriam ser criados na colônia britânica do novo mundo na América (Pinto e Buffa, 2009).

A Universidade de Portugal, segundo Verger (1990), foi criada em 1288 sob o poder régio ou papal, dependendo da localidade. A primeira instituição portuguesa denominada de Estudos Gerais de Lisboa foi fundada por Dom Dinis.

sua disposição acomodações, refeições, salas comuns, bibliotecas e espaços para praticas esportes. Nos Estados Unidos, o termo college designa instituições de educação superior, frequentemente independentes (...)". O termo College foi utilizado nos Estados Unidos pois os primeiros fundadores se formaram em Oxford em Cambridge.

${ }^{67}$ Fusão essa que também ocorreu nos Estados Unidos. 


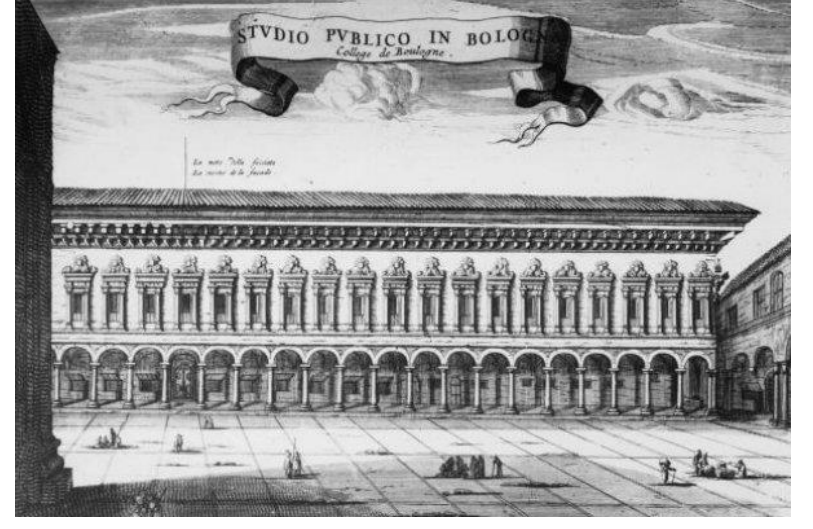

Figura 16- 'Studio Público em Bolonha', Universidade de Bolonha, sem data.

(Fonte: http://revistagalileu.globo.com/Revista/Common/0,,EMI34390417770,00-AS+UNIVERSIDADES+MAIS+ANTIGAS+DO+MUNDO.html, acessado dia 20 de junho de 2016, as 22:36 horas).

A diferença da universidade portuguesa para o restante da Europa é que ela não teve influência econômica ou jurídica; mas se assemelhava, em questão organizacional, à de Bolonha porem sendo submissa à Igreja. Segundo Janotti (1992) a universidade portuguesa foi transferida diversas vezes desde sua fundação e, somente em 1536, teve seu local fixo estabelecido em Coimbra. Por essa constante mudança de localização, a universidade ficou conhecida como Universidade Lisboa- Coimbra e serviu de importante modelo para as universidades que viriam a ser estabelecidas no Brasil.

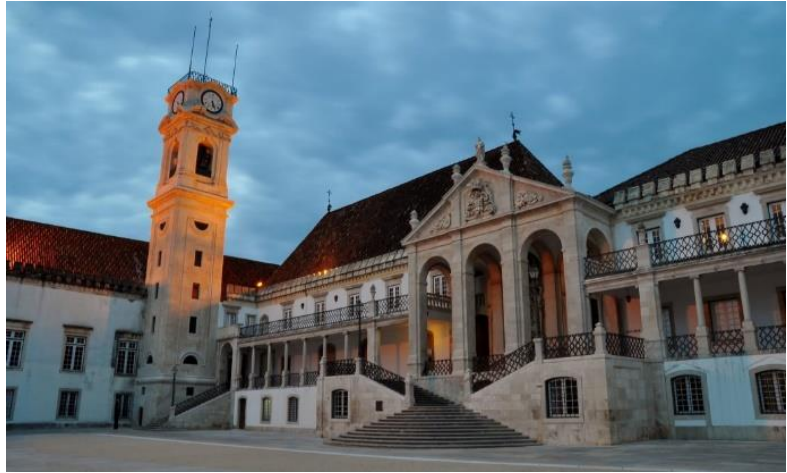

Figura 17- Universidade de Coimbra, sem data. (Fonte: http://www.colegioweb.com.br/noticias/universidade-decoimbra-aceitara-notas-enem-em-processo-seletivo.html, acessado dia 20 de junho de 2016, as 22:40 horas).

\subsection{A Renascença e a Revolução Industrial: novas demandas profissionais, novas instituições superiores}

A partir do século XIV a Europa foi marcada por guerras e cruzadas, fome, doenças como as pestes negra e bubônica, crises da Igreja e dos impérios, navegações marítimas - e a descoberta do Novo Mundo. O aumento de atividades comerciais e culturais de cunho científico- filosófico contribuíram para que ocorressem mudanças políticas, econômicas e sociais. Cambi (1999) afirma que a Itália, nesse 
contexto, ainda contava com uma forte presença do humanismo ${ }^{68}$ que de lá se espalhou por regiões da Europa, abrindo caminho para a Renascença.

Segundo Manacorda (1989 apud Mahler, 2015), com a presença do humanismo nas universidades, a instituição passa a ser um novo espaço livre de influências e controle religiosos; foi exatamente pelo fim da presença religiosa que a quantidade de alunos que estudavam de forma gratuita foi reduzida, permanecendo apenas estudantes que eram financiados.

Ainda segundo o autor, as universidades começaram, então, a privilegiar alunos com maior poder aquisitivo, chegando até a reservar vagas para os descendentes de doutores.

Com a Reforma e o Concílio de Trento, em 1548, as universidades contaram com o apoio político e, nos países de fé católica, a Igreja se aproxima da universidade e, consequentemente, a ciência moderna se realiza mais intensamente nas Academias e não nas universidades (Pombo, 1999 apud Mahler, 2015).

${ }^{68}$ Segundo Salomão (2011): "O humanismo apresentava um novo ideal de homem, ele se torna a figura central da sociedade, que deve desenvolver toda a sua capacidade humana de forma equilibrada; para tanto, necessita de uma formação baseada essencialmente na leitura dos clássicos gregos e latinos, objetivando
O desenvolvimento da prensa causou uma grande mudança na educação já que quanto mais os livros eram impressos, mais com eles passaram a ter maior circulação. Outros fatores importantes nos séculos XVII e XVIII foram a ciência e a filosofia que modificaram a visão que o homem tinha a respeito do mundo e acabaram por contribuir para a criação da universidade moderna.

"A partir do Renascimento e, mais ainda, da revolução copernicana, há uma inflexão do conhecimento que, por um lado, o afasta da mera utilidade na formação de recursos humanos para a sociedade e, por outro, abre a perspectiva moderna de intervenção técnica, em uma época de redefinição do próprio conceito de ciência. Aos poucos o foco se desloca da interpretação de um acervo consagrado de textos para a observação da natureza, para a descrição da realidade sem nenhuma interposição doutrinária. De sorte que, a ciência já não pode ser entendida como (...) uma mera disciplina a ser ensinada. (...) o científico se converte num programa de estudos. Trata-se, portanto de definir a ciência a partir da noção de pesquisa" (Castilho, 2008, p. 09).

Do século XVI ao XVIII ocorreram as reformas universitárias ${ }^{69}$, em sua maioria impostas pela coroa, que asseguraram o controle

descobrir uma humanidade feita de valores universais, elaborados e produzidos pela Antiguidade".

${ }^{69}$ No fim do Antigo Regime as universidades sofreram uma crise causada mais por sua própria imagem e pelas "funções que lhe atribuía a sociedade da época" do que o modelo já ultrapassado que eram as universidades. Desde sua origem essas 
estatal das instituições de ensino superior e asseguravam algumas inovações como a criação de novas disciplinas e a modernização das instituições; essas reformas se iniciaram na Alemanha e, em 1760, em países católicos (Charle e Verger, 1996).

As reformas que aconteceram nas universidades seguiram ideias de revolucionários franceses e de Napoleão, além de prussianos como Humboldt. Segundo Charle e Verger (1996), até a Revolução Francesa não houveram resultados efetivos para que as universidades saíssem do modelo do Antigo Regime e, por essa razão, em 1793 a Convenção aboliu as reformas e as universidades francesas. Durante os anos seguintes também houve essa queda por todo o território europeu ${ }^{70}$.

As ideias iluministas ${ }^{71}$ foram responsáveis pelas universidades Humboldtianas e Napoleônicas cujos ideais chegaram, em 1806, na Universidade de Paris e, em 1810, na de Berlim. Até o século XIX a

instituições de ensino superior já necessitavam de um remodelamento, o que foi ainda mais ressaltado no século XVI com o questionamento dos filósofos e humanistas renascentistas. Apesar destes questionamentos, as universidades resistiram e continuou em desenvolvimento (Charle e Verger, 1996, p. 56- 57).

70 Segundo Charle e Verger (1996, p. 64- 65), há duas classificações: (a) "Estabelecimentos de excelência, de vocação antes de tudo cultural", estas é um local de ensino de "alto nível, livre e desinteressado"; (b) As academias, estas não organizavam o ensino, mas por concentrarem instituições científicas (por coleções influência religiosa nestas instituições passou a ser diminuída (Ribeiro, A., 2008).

A Revolução Industrial, como já apresentado no capítulo anterior, transformou as cidades e a vida das pessoas, além de contribuir para o desenvolvimento de novos materiais, da ciência e do avanço tecnológico; este novo cenário forçou as universidades a realizarem rápidas mudanças para que conseguissem acompanhar o desenvolvimento tecnológico e a expansão de novos conhecimentos, o que também acabou modificando fisicamente os espaços universitários.

Pelas consequências do avanço tecnológico e pelo aumento de mercados e novas áreas industriais foi preciso suprir a falta de profissionais para as indústrias e estabelecer novos critérios curriculares. Outra necessidade, especialmente após o final da Segunda Grande Guerra, com o avanço da indústria automobilística,

e bibliotecas), "substituíram em grande medida as universidades no duplo papel que estas tinham mantido durante a Idade Média, de conselheiras do príncipe e de instâncias legitimadoras do saber".

${ }^{71}$ Ribeiro, A. (2008, p. 30) fala que, no período do lluminismo, foi proposta a criação de escolas especializadas que formassem os estudantes e academias que fossem encarregadas pelas pesquisas científicas e culturais, pois as universidades possuíam um "resquício da tradição medieval". Essa é a origem das universidades modernas francesas que surgiram no fim do século XVIII. 
foi repensar e expandir a quantidade e dimensões das estradas e ruas; com o aumento das cidades foram necessárias constantes reestruturações urbanas, o que abriu oportunidades para profissionais ligados ao espaço urbano ${ }^{72}$ (Caram, 2014).

"Para atender a demanda de profissionais voltados para o setor industrial e a demanda de projetos especiais destinados a suprir as necessidades de infraestrutura ferroviária, portuária e urbana foram criadas escolas técnicas, institutos tecnológicos e universidades, cujos currículos foram sendo reestruturados para suprir não apenas a formação clássica, mas agora também a formação técnica, voltada às indústrias e contingências urbanas" (Caram, 2014, p. 38)

Há uma ligação entre a ciência e as indústrias para aprimorar o sistema produtivo com custos de produção e comercialização reduzidos. Todos esses fatos fizeram com que a ciência ganhasse um espaço nos currículos universitários. Segundo Singer (1989), o ensino científico foi transformado de acordo com as distintas imposições dos modos de produção. Segundo Caram (2014, p. 38), para a instrução desses profissionais ligados ao setor industrial e aos projetos de infraestrutura urbana "foram criadas escolas técnicas, institutos tecnológicos e universidades", seus currículos foram adaptados para oferecerem uma formação clássica e técnica.

\subsection{As universidades modernas e contemporâneas}

Novas instituições surgiram: de sessenta universidades, em 1550, foram criadas mais oitenta e três até 1790 , mas não em todos os países; em Portugal, na Polônia e na Inglaterra, por exemplo, não ocorreram novas instituições de ensino superior. As mais promissoras foram as nascidas na Alemanha e Europa Oriental.

As universidades de origem medieval continuavam sendo importantes servindo, pelo menos na teoria, de modelo para a constituição de novas instituições; na prática muitas modificações

dos materiais, utilizar maquinário para o auxílio em canteiros de obras, empregar a Geometria para a representação gráfica da obra e, a partir desse período, escolas especializadas passavam a formar profissionais preparados para essa nova realidade (Benevolo, 2014). 
desse modelo primário ocorreram. As universitas ${ }^{73}$ medievais foram substituídas pelas "diversidades das práticas locais e dos caracteres nacionais" (Charle e Verger, 1996, p. 42).

A universidade era sempre definida por "seu caráter de instituição oficial, fundada ou reconhecida por uma autoridade religiosa ou política" (Charle e Verger, 1996, p. 43-44).

O papel da Alemanha na construção de uma universidade moderna ${ }^{74}$, a partir do século XVII, é importante:

\begin{abstract}
"esse modelo é baseado no princípio de que a humanidade aspira à verdade. Esta, não podendo ser adquirida na sua totalidade, deveria ser incessantemente procurada, em todas as direções possíveis. A concepção de universidade ganhou, a partir disso, uma dimensão inovadora na história (...): a universidade moderna nasceu (...) voltada para reelaborar e criar novos conhecimentos e elaborar a cultura. A ela coube integrar, em sua origem, as funções de ensino e pesquisa, (...) e não apenas a transmissão da verdade constituída. O ensino universitário passou a ser concebido como uma 'aprendizagem da atitude científica'” (Meneghel, 1992, p. 07 apud Mahler, 2015, p. 56).
\end{abstract}

\footnotetext{
${ }^{73}$ Charle e Verger (1996) falam sobre as universidades protestantes (luteranas, calvinistas e anglicanas) e as católicas (fundadas ou tomadas por jesuítas em alguns locais como na Alemanha).

${ }^{74}$ Aumentaram, durante a Era Moderna, a quantidade de instituições strictu sensu em universidades com maior ou menor poder de proferir colações de grau, mas que não deixavam de educar alunos no ensino superior (Charle e Verger, 1996).
}

No final do século XIX é apresentada por Wihelm von Humboldt uma proposta de universidade voltada à pesquisa em Berlim, proposta esta que pode ser considerada a origem das universidades atuais cujo modelo unia o ensino e a pesquisa voltados para o conhecimento sem a Teologia como área centralizadora do ensino.

A Alemanha passa, então, a ser o primeiro país que adotou um modelo moderno ${ }^{75}$ de "produção científica, com corpo de disciplina, definindo-se as funções específicas de um professor universitário" (Mahler, 2015, p. 56). Esse modelo acabou sendo muito criticado por ser elitista e conservador, mas:

"os êxitos científicos alcançados pelo modelo alemão, principalmente o método de seminário, motivaram sua difusão entre as demais universidades no mundo. Livros, revistas e textos produzidos entre suas paredes constituíram referências no meio acadêmico de vários países e as diversas adaptações sofridas pelo modelo em outras universidades elevaram o nível de sua

\footnotetext{
${ }^{75}$ Segundo Caram (2014, p. 84), a Universidade de Berlim foi importante para a "formação do conceito de universidade moderna" e o memorando de Humboldt serviu de modelo de planejamento e pedagogia para outras futuras universidades modernas europeias.
} 
produção científica" (Matos, 1999 apud Mahler, 2015, p. 56).

Segundo Alberto (2008, p. 329), no decorrer do tempo a relação do ensino realizado em conjunto com a investigação foi interrompida: nos Instituten a investigação não ocorria como nas universidades, não havia o desenvolvimento de novas áreas científicas e não havia plano de carreira, ou seja, os docentes não poderiam se desenvolver profissionalmente nas cátedras e o trabalho cientifico- intelectual acabava ficando distante dos mesmos; enquanto que nas Technische Hochschulen a base curricular foi expandida e nelas inclusa disciplinas das áreas de humanas e ciências sociais, mantendo para a instituição o status de universidade.

76 A Lei Le Chapelier criada durante a Revolução Francesa fechou todas as universidades francesas e corporações de ofício, Napoleão as reabriu utilizando um modelo mais centralizado e dividiu o império em quarenta academias voltadas

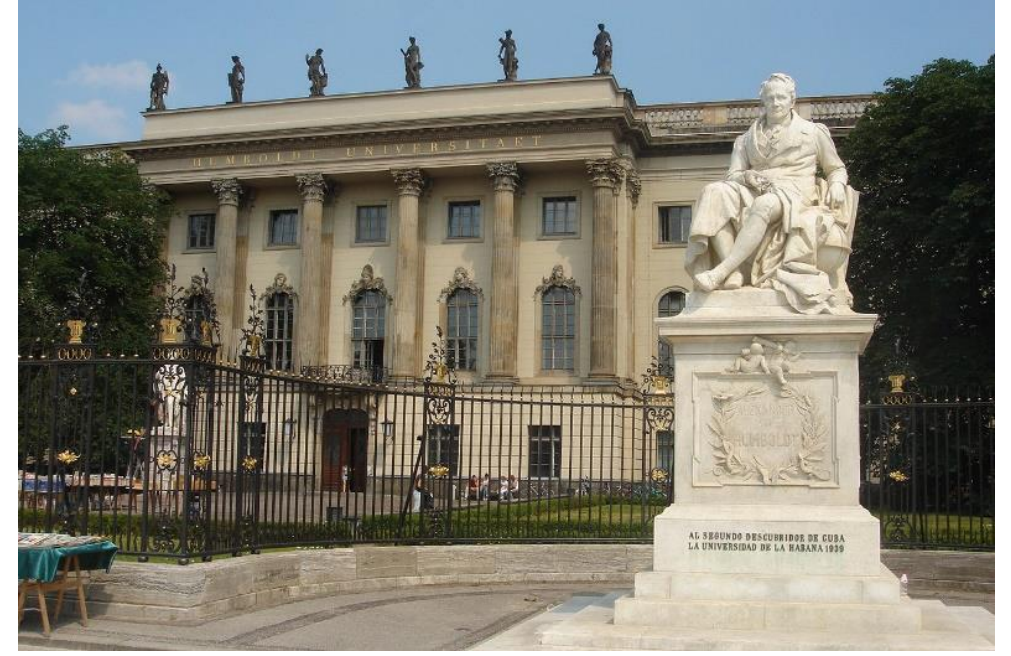

Figura 18- A universidade Humboldt, em Berlim, e, a direita, a estátua de Alexander von Humboldt, sem data.

(Fonte: https://pt.wikipedia.org/wiki/Universidade_Humboldt_de_Berlim, acessado dia 23 de junho de 2016, as 20:310 horas).

Na França do ano de 1815, após a Revolução Francesa ${ }^{76}$ e durante as conquistas napoleônicas, cerca de sessenta universidades foram extintas, vinte e duas abolidas e doze foram "substituídas por escolas especiais ou faculdades isoladas" (Mahler, 2015, p. 58).

para o ensino de Teologia, Medicina, Matemática, Direito, Física e Letras (Alberto, 2008). 
No século XX as Grandes Écoles e as estatais voltadas para a pesquisa foram reorganizadas.

Na Inglaterra, em Oxford e Cambridge, as mudanças ocorreram aos poucos e retiraram a presença religiosa das instituições permitindo o ingresso de mulheres, essas universidades foram influenciadas pelas da Alemanha. A universidade britânica moderna tem como objetivo ser um espaço de "espírito ou liberal" com normas próprias, assim como são as alemãs e estadunidenses. Já as universidades francesas e soviéticas eram funcionais e "do poder" a partir dos serviços que realizam para a nação (Mahler, 2015, p. 59).

Ainda segundo Mahler (2015), a Revolução Industrial enfraqueceu os Colleges como modelo espacial de ensino superior, o que foi superado no século XIX com a integração urbana das universidades.

Já em Portugal, no século XVIII, a Coroa sob influência do lluminismo, através do Marquês de Pombal, realiza ações modernizadoras:

"No Brasil, a transição do modelo escolástico para a formação profissional teve suas origens no projeto de transformação da Universidade de Coimbra, realizado no final do século XVIII, (...) para livra-la do predomínio do ensino jesuíta e da tradição da contra- reforma, projeto trazido por membros da corte de D. João VI, rei de Portugal, em sua vinda ao Brasil em 1808. Essa transformação, conhecida como Reforma Pombalina, (...) buscou introduzir em Portugal, e mais tarde no Brasil, o ensino técnico e os conhecimentos práticos, sem a estrutura universitária que havia ficado demasiado identificada com a corporação religiosa, e que só seria implantada no Brasil na terceira década do século XX" (Schwartzman, 1996, cap. 2 apud Mahler, 2015, p. 59).

A universidade durante o período de 1780 a 1860 foi marcada pelos seguintes princípios: (a) A presença de características medievais e da Era Moderna; (b) A manifestação de distintos modelos de organização na Alemanha e França; (c) Realização de atividades de pesquisa fora das universidades através de academias ou por eruditos; (d) Formação de uma pequena parte da sociedade, já que neste momento a aristocracia desprezava o ensino escolar, o que ocorreu durante o Antigo Regime; (e) A formação de um espaço político influenciador de movimentos nacionais e liberais, no século XIX (Charle e Verger, 1996). O espaço universitário também sofreu modificações nesse período sendo largamente ampliado. 
Os modelos utilizados para a reformulação ${ }^{77}$ da universidade tradicional, no século XIX, foram o britânico, College, o francês, centralizado e estritamente disciplinar, e o alemão, clássico (Charle e Verger, 1996). Neste momento, os modelos universitários tornaram-se mais "ambiciosos, mostrando sofisticação e concepções mais unificadas", o aumento de estudantes das áreas de conhecimento ensinadas também foram importantes para situar as universidades no espaço urbano (Mahler, 2015, p. 60).

Já nos anos de 1860 a 1940, o ensino foi marcado pelo seu desenvolvimento seguindo o modelo alemão, sobretudo em países cujas universidades ainda permaneciam tradicionais. Apesar das distinções étnicas, religiosas, econômicas e urbanas que ocorriam entre regiões.

Até meados do século XIX o ensino oferecido nas instituições superiores dos Estados Unidos era, em sua grande parte, seguidoras dos modelos clássicos, mesmo elas terem passado por um desenvolvimento de secularização. Essas limitações foram alvo de críticos que almejavam um currículo mais técnico e voltado para as realidades do país.

"Como os estados não possuíam recursos suficientes para oferecer esse tipo de educação, o senador Justin Morril apresentou ao congresso um projeto de lei, a fim de garantir recursos federais a colleges que oferecessem cursos na área da agricultura. (...) a lei deu origem aos land-grant colleges. O governo federal se comprometia a doar terras para os estados usarem-nas como bem lhes aprouvesse, a fim de tornar possível a fundação de uma universidade estadual, que se voltasse para o atendimento das necessidades mais práticas em sua região" (Lucas, 1994 apud Oliven, 2005, p. 120)

No século XX foram criados nas cidades menores os junior Colleges que ofereciam os dois primeiros anos dos Colleges e serviam como um instrumento facilitador para transferências de alunos que desejassem ir para Colleges e que possuíam bons rendimentos escolares. Tempo depois esses juniors Colleges passaram a oferecer disciplinas técnicas e, então, surgem os community Colleges, a maioria pertencentes aos Estados (Oliven, 2005).

\footnotetext{
77 Segundo Charle e Verger (1996), uma importante característica das universidades modernas é o aumento gradativo da autonomia universitária e, consequentemente, a redução do controle político sobre as mesmas.
} 
O pós- Segunda Guerra foi importante para a educação na América Latina pois foi neste momento em que as estruturas físicas universitárias foram consolidadas.

\subsection{O ensino no Novo Mundo: a universidade na América Latina e nos Estados Unidos}

\begin{abstract}
"Na América Latina, as mais antigas fundações foram as de São Domingos (1538), a de Lima (1551) e a do México (1551); instituídas por decreto real com estatutos inspirados nos de Salamanca e de Alcalá, quase sempre controladas por ordens religiosas (Dominicanos, Jesuítas), ensinando principalmente Teologia e Direito Canônico, as universidades da América Latina ${ }^{78}$ eram claramente fundações coloniais e missionárias: vinte delas foram estabelecidas antes da independência, com maior ou menos sucesso, nas principais colônias espanholas. No Brasil, não houve nenhuma. Na América do Norte, as primeiras universidades, sob a forma de colégios, foram antes de tudo o fruto de interesses locais: tratava-se de formar pastores e administradores de que necessitavam as colônias inglesas" (Charle e Verger, 1996, p. 42).
\end{abstract}

\footnotetext{
78 O modelo pedagógico adotado na América Latina seguia a linha francesa, que no período influenciava a Espanha, e, consequentemente, o ensino superior era voltado à elite (Mahler, 2015).
}

Foi no ano de 1538 que a primeira universidade no continente foi criada "por bula papal no convento dominicano de Santo Domingo". Outras universidades importantes foram criadas depois no México e em Lima, com autorização real (Mahler, 2015, p. 52).

Boaventura (1192, p. 59 apud Mahler, 2015, p. 52-53) apresenta três distintos períodos das universidades na América Latina: (a) No período de colonização espanhola e a neocolonização francesa cujas reformas nacionais tiveram grande "tendência norteamericana"; (b) As fundadas no século XVI "compreendidas como marcos da posição da Coroa em relação ao Novo Mundo" onde não havia espaço para pesquisa ou para a preservação da cultura local, o ensino era de Filosofia e Teologia; (c) No século XIX, com os países já independentes, "as universidades ganharam novo impulso e foi reforçado o domínio cultural francês", neste momento ocorreu a autarquia da "instituição francesa, fragmentando a universidade, com ênfase nas faculdades isoladas".

As estruturas herdadas da colonização foram lentamente questionadas; somente a partir de 1918 que um protesto estudantil 
em Córdoba, Argentina, questionou a reforma universitária e então

seus ideais foram espalhados por países como Peru, Chile, México,

Uruguai, Cuba e Colômbia (Charle e Verger, 1996).

\begin{tabular}{cc}
\hline Ano & Universidade \\
\hline 1538 & Universidade de Santo Tomás de Aquino, \\
& República Dominicana \\
\hline 1551 & Universidade do México, México \\
\hline 1551 & Universidade Maior de São Marcos, Peru \\
\hline 1721 & Universidade Central da Venezuela, \\
& Venezuela \\
\hline 1788 & Chile \\
\hline 1821 & Universidade de Buenos Aires, Argentina \\
\hline 1833 & Universidade do Uruguai, Uruguai \\
\hline
\end{tabular}

Tabela 3- Cronologia das primeiras universidades fundadas na América Latina.

(Fonte: Mahler, 2015, p. 51). 
Já a primeira universidade fundada em território norte americano, segundo Pinto e Buffa (2009), foi a Universidade de Harvard, em 1636. Apesar de seus fundadores terem formação em Oxford e Cambridge, as instituições fundadas nos Estados Unidos eram semelhantes aos Colleges pois alojavam os alunos.

"Inicialmente absorveram e replicaram o modelo inglês, até que quatro fatores convergiram e provocaram a primeira alteração na estrutura de ensino americano: a rejeição à tirania dos estudos teológicos e clássicos, a emergência do paradigma da ciência, (...) e a exigência de uma maior democracia para a educação" (Alberto, 2008, p. 331).

No período da Independência Americana, em 1776, o país já possuía nove Colleges: Harvard College fundado em 1636 em Massachussets, William and Mary fundado em 1693 na Virgínia, Yale College fundado em 1701 em Connecticut, o College de New Jersey, que depois mudou seu nome para Princeton, fundado em 1746, o King's College, que depois mudou seu nome para Columbia, fundado em 1754 em Nova lorque, o College de Philadelphia, que depois mudou seu nome para Universidade da Pennsylvania, fundado em

79 “(...) foram buscar nos campos o refúgio necessário para as atividades acadêmicas, implantando suas atividades em espaços permeados por áreas verdes e criando um modelo que se espalhou pelos Estados Unidos, principalmente após
1755, o College de Rhode Island, que depois mudou seu nome para Brown, fundado em 1765, o Queen's College, que depois mudou seu nome para Rutgers, fundado em 1766 em New Jersey, e o Darthmouth College fundado em 1769 em New Hampshire (Turner, 1995)

Pinto e Buffa (2009, p. 37) explicam que essas universidades são conhecidas como Ancient Eight ou universidades da IVy League que foram fundadas dentro das cidades, mas que possuíam tantas áreas verdes ${ }^{79}$ que "simulavam uma espacialidade rural".

a implantação da University of Virginia, idealizada por Thomas Jefferson a qual se tornou um relevante paradigma urbanístico para a implantação dos campi universitários" (Caram, 2014, p. 84). 


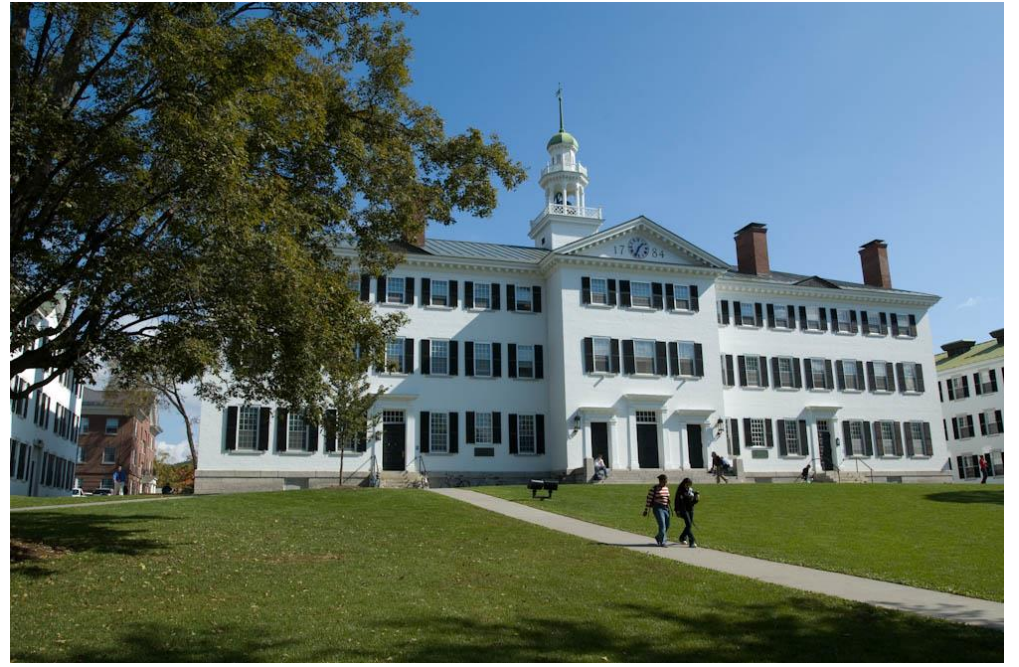

Figura 19- Dartmouth College, sem data.

(Fonte: http://raunerlibrary.blogspot.com.br/2011/08/dartmouthhall.html, acessado dia 23 de junho de 2016, as 16:34 horas).

A característica que mais se destaca no ensino superior estadunidense desde sua origem "é a concepção de Colleges e universities como comunidades nelas mesmas, (...) como cidades microscópicas"; nesses espaços, diferente do que ocorria no modelo inglês, possuíam salas de aulas, dormitórios, refeitórios e espaços de lazer (Pinto e Buffa, 2009, p. 36).

\footnotetext{
${ }^{80} \mathrm{~A}$ presença desses espaços verdes tornou-se algo tão importante para a cultura universitária do país que, mesmo em universidades que estavam localizadas dentro do perímetro urbano, existia algum espaço com verde ou um rio/lago.
}

Turner (1995) explica que inicialmente cada College era construído de maneira individual e não no aglomerado da universidade, assim, cada College tinha sua própria autonomia como uma comunidade, essa disposição permitiu a inserção de espaços verdes abertos ${ }^{80}$. Outra inovação que ocorreu nos Estados Unidos foi a localização dos Colleges no limite urbano ou no campo contribuindo para que cada College se transformasse em algo semelhante à pequenas cidades, inclusive em seu traçado urbano.

Foi no século XIX que a universidade americana ganha força e se transforma em um verdadeiro sistema. A educação passa a ser um dos principais valores da cultura do país e, para acompanhar todas as mudanças que estavam ocorrendo, sobretudo com a implantação do Morrill Act em 1862, o antigo modelo de College precisou ser reformulado: instituições científicas implantadas pela elite seguiram o modelo alemão de ensino- pesquisa, como ocorreu em Stanford, fundada na Califórnia em 1876, e em Cornel e Chicago, fundadas em 1892, em seguida as antigas universidades do Leste também se modernizaram seguindo os modelos europeus. Foi no século XX que 
a pesquisa passa a ter grande importância nas universidades americanas, os laboratórios de pesquisas ${ }^{81}$ e institutos, ligados mais ou menos às universidades, foram criados em larga escala e as disciplinas passam a ser organizadas por departamentos e não mais por cadeiras, permitindo a inovação (Charle e Verger, 1996).

Outra característica inovadora nas universidades norteamericanas é a possibilidade de acesso que a população em geral têm ao ensino superior, mostrando o fim do elitismo no país, a partir de 1950 (Charle e Verger, 1996).

Contudo, a situação atual apresenta um claro conflito; Andrew Rossi em seu documentário 'Torre de Marfim: a crise universitária americana', de $2014^{82}$, fala sobre como os Estados Unidos conseguiram oferecer um ensino superior a uma porcentagem da população maior do que ocorreu em qualquer sociedade no mundo e na história, porém, o problema atual dessas universidades é seu alto custo: a dívida de empréstimos estudantis chegou a um trilhão de dólares, o que também compromete a economia do país pois é número de inadimplentes é cada vez maior.

\footnotetext{
${ }^{81}$ Caram (2014) fala que as universidades estadunidenses modernas, voltadas para a ciência e para a pesquisa, já vinham sendo formadas desde o século XVII.
}

A tensão maior é que atualmente um diploma superior não garante mais empregos satisfatórios pelos quais os alunos almejavam antes de saírem das faculdades, muitos diplomados estão trabalhando como garçons, motoristas ou faxineiros; a expectativa de um emprego compensador pelos anos e altos custos de ensino não correspondem a atual realidade do país.

Essas realidades podem ser indicativas de um futuro onde a instituição de ensino superior está fadada à falência, sobrevivendo apenas poucas universidades. As universidades estão buscando, então, diminuir seus gastos: as taxas têm sido a saída para as universidades pois enquanto as verbas diminuíram no país, as taxas, desde 1980, aumentaram.

Além das taxas, outro fator financeiro que ajuda manter uma universidade são os financiamentos estudantis. Para atrair alunos, as universidades passaram a oferecer diferenciais como piscinas, áreas de recreações com academia e paredões de escalada, espaços para bronzeamento artificial, televisores de plasma e quadras esportivas em 
específicas, além das próprias festas universitárias ${ }^{83}$. Os espaços de ensino estão sendo transformados em espaços de empreendedorismo e recreação ${ }^{84}$.

Esse processo mercantilista que ocorre nas universidades acaba distanciando os jovens de rendas mais baixas ${ }^{85}$ de um curso superior e deixa os espectadores com a seguinte dúvida: 'qual é o papel das universidades frente à desigualdade de renda nunca vista anteriormente na história dos Estados Unidos?'.

O documentário é importante para a discussão em relação à mercantilização das universidades Americanas e a crescente adoção desse paradigma em terrar brasileiras: a questão da perspectiva do ensino semelhante à mercadoria resultando em segregação social e como esse modelo é capaz de diminuir a qualidade dele mesmo, especialmente se a questão for relacionada à quantidade de população; é possível aprender com as valiosas lições estadunidenses

\footnotetext{
${ }^{83}$ É apresentado que os estudantes pouco estudam ou pouco escrevem dentro das salas de aulas, a reclamação estudantil é que as universidades oferecem muitos distrativos e pouca orientação ou preocupação da própria universidades em relação ao desempenho dos alunos (Documentário 'Torre de Marfim: a crise universitária americana', de 2014, Andrew Rossi).
}

e aplicá-las à crise que as universidades brasileiras, especialmente as públicas, estão sofrendo.

\subsection{Universidades no Brasil: um início tardio}

A Universidade no Brasil percorreu um longo caminho para tornar-se a instituição como é conhecida atualmente.

O início do ensino superior ocorreu com a criação de cursos superiores profissionais em Salvador e depois no Rio de Janeiro, pelo Príncipe Regente D. João. Esses cursos eram militares ou não, dependendo das necessidades profissionais que o Estado tinha naquele momento. Cursos como arquitetura, música, desenho e história foram implantados com a vinda da Missão Francesa, junto com a família real, em 1816 (Pinto e Buffa, 2009).

${ }^{84}$ Quanto mais espaços diferenciados são criados pelas universidades, mais vão subindo as taxas estudantis para que as universidades possam pagar por esses gastos. As universidades também estão cada vez mais endividadas.

85 O documentário ainda apresenta os seguintes dados: de 1978 a 2010, as taxas universitárias subiram $1120 \%$, valor muito mais inflacionado do que qualquer outro serviço no país durante o mesmo período. 
Segundo Pinto e Buffa (2009, p. 45-46), também foram criadas, em 1827, as Academias de Direito de São Paulo e Olinda:

"Ao longo do século XIX, esses cursos e escolas sofreram transformações, outros foram criados, mas o fundamental é que o ensino superior brasileiro, desde sua criação até a primeira metade do século $X X$, foi estruturado em estabelecimentos isolados. No decorrer do período, houve várias tentativas frustradas de criação de universidades, mesmo após a proclamação da República. As resistências à ideia de criação de uma universidade no Brasil contaram com o decidido apoio dos positivistas brasileiros que consideravam a universidade uma instituição anacrônica".

Segundo Caram (2014), ocorreram desde 1554 cerca de 30 frustradas tentativas de criação de uma universidade ${ }^{86}$ antes da Universidade do Rio de Janeiro. A autora fala sobre a existência de cursos considerados de ensino superior no Brasil colônia, nos séculos XVI e XVIII, criados por jesuítas na Companhia de Jesus ${ }^{87}$; esses primeiros cursos de Filosofia e Teologia aconteciam em colégios e seminários (Caram, 2014).

\footnotetext{
${ }^{86}$ Segundo Mendonça (2000), ocorreram algumas tentativas de transformar os colégios jesuítas em universidades, mas o governo de Portugal barrou todas propositadamente para que a colônia mantivesse a relação de dependência com a Universidades de Coimbra.
}

A partir de 1750, Marquês de Pombal realizou medidas modernizadoras em Portugal com o intuito de "diminuir a dependência econômico- política" em relação à Inglaterra, uma das várias políticas criadas foi a expulsão dos jesuítas do reino e das colônias, assim, o ensino antes realizado pelos religiosos passou a ser controlado pela monarquia o que permitiu a adoção de novas disciplinas universitárias (Caram, 2014, p. 76).

Essa "reforma educacional pombalina" permitiu incluir "um pensamento moderno na sociedade e reorientar a educação universitária tradicional (...) para os princípios da ciência e da pesquisa". No ano de 1777, Dona Maria I tornou-se rainha de Portugal, posteriormente do Brasil, e "destitui Pombal e anulou grande parte das intervenções e medidas que haviam sido implementadas" (Caram, 2014, p. 78).

Com a expulsão dos jesuítas, grandes mudanças foram realizadas nos seminários e nos colégios portugueses e brasileiros.

\footnotetext{
${ }^{87}$ As atividades de ensino da Companhia de Jesus eram voltadas para a catequese de índios e eram padronizadas. “O primeiro colégio foi fundado em 1550, na Bahia considerado modelo para a constituição de outros colégios similares" (Caram, 2014, p. 76).
} 
Caram (2014), ainda descreve acercas das consequências para o Brasil da expulsão dos jesuítas, como o encerramento das atividades de ensino realizadas em solo colonial, restando apenas os edifícios. Segundo a autora, a dificuldade era:

"em implantar uma pedagogia de ensino direcionada para o estudo, pesquisa e ciência, devido à cultura tradicional e ao poder da Igreja que representava a religião do Estado português, ensejou motivos para a fundação de academias de ciências, criadas pelos monarcas portugueses" (Caram, 2014, p. 79).

Ainda segundo Caram (2014), nem mesmo durante o período pombalino foram estabelecidas academias de ciências, ao contrário do que ocorria em distintas cidades europeias como Roma e Paris. As Academias somente apareceram em Portugal no reinado de Dona Maria I, porém, para a existência de uma universidade moderna no reino, era necessário que o Estado fosse laico e a instituição formada por pesquisadores estrangeiros; como isso não ocorreu, acabou contribuindo para o atraso da concretização de uma universidade relacionada a esses paradigmas também aqui.

A vinda da família real para o Brasil contribuiu para a abertura dos portos e a modernização da cidade do Rio de Janeiro. Diversas melhorias foram feitas na cidade para que ela pudesse se assemelhar às cidades europeias, as ações mais importantes a serem recortadas são a o aumento e o restauro do ensino superior no país, assim como a instalação de novas escolas e espaços de ensino (Caram, 2014, p. 80).

A corte portuguesa na colônia modificou os rumos do ensino no Brasil: foi necessário criar cursos técnicos e administrativos para suprir as necessidades da monarquia.

Já na República, as escolas eram laicas e estatais e funcionavam sob supervisão do Estado. Segundo Cunha (2007 apud Caram, 2014, p. 81) foram as "escolas, academias e faculdades", como instituições de ensino superior, que iriam organizar os cursos de uma forma especializada e seriada.

A Universidade do Rio de Janeiro, criada no ano de 1920, é considerada a primeira instituição de ensino superior do país; seguida pela Universidade de Minas Gerais, em 1927, e a de São Paulo, em 1934. Estas universidades surgiram a partir da reorganização de faculdades já existentes e "reunidas sob uma reitoria recém-criada" (Pinto e Buffa, 2009, p. 46). O ensino superior brasileiro era marcado por escolas isoladas e foi o último país da América Latina a fundar instituições de ensino superior.

“Embora não seja agradável assinalar, o Brasil foi o último país das Américas a lançar as bases de ensino, 
sob o regime universitário. Naquela época, ao completar-se o século XIX, o Novo Mundo já possuía as seguintes organizações desse gênero: Estados Unidos (78), Canadá (12), México (2), Guatemala (1), Honduras (1), São Domingos (1), Cuba (1), Venezuela (1), Colômbia (4), Peru (2), Bolívia (4), Equador (1), Argentina (2), Uruguai (1), Chile (1) e Paraguai (1). (...) O Brasil somente teve a sua primeira universidade quase ao finalizar o primeiro quarto do século atual (1920), quando já se multiplicavam tais centros de estudos no Canadá, na Argentina, no México, no Peru, etc. Outros países novos, como a Austrália (4) e Nova Zelândia (3), África do Sul (2), possuíram tais instituições antes de nós" (Campos, 2004, p. 25).

Já em 1934, Gustavo Campanema tornou-se ministro da educação e saúde. Neste cargo, Campanema foi responsável por organizar o texto que estabelece as bases para criação da Universidade do Brasil. Este foi o modelo padrão para as universidades do país criada a partir da Universidade do Rio de Janeiro. A estrutura da Universidade do Brasil compreendia os prédios já existentes da antiga Universidade do Rio de Janeiro e novos prédios administrativos (Caram, 2014).

Segundo Pinto e Buffa (2009), o trabalho foi demasiado árduo. Vários projetos foram elaborados e o processo teve longa duração. A obra iniciou-se após a gestão de Capanema. Várias equipes foram responsáveis pela implantação da Universidade do Brasil e dentre elas uma equipe de arquitetos e internacionais como Le Corbusier e Marcello Piacentini. Um projeto alternativo menos grandioso que utilizava de forma melhor os terrenos disponíveis e os recursos foram apresentados por Ernesto de Souza Campos e Pujol Júnior.

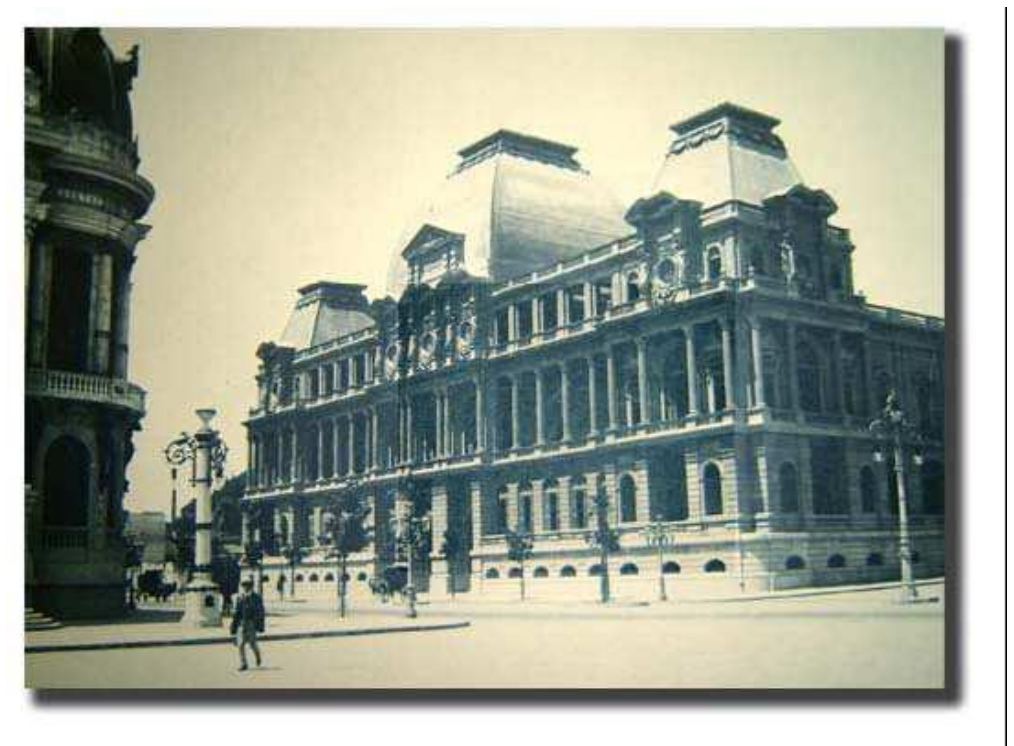

Figura 20- Fotografia do prédio da Escola Nacional de Belas-Artes, integrante da Universidade do Brasil, na Avenida Central em 1910.

(Fonte: FERREZ, M. O Álbum da Avenida Central: 8 de março de 1903 - 15 de novembro de 1906. Rio de Janeiro: F. Bevilacqua \& Cia. / Ex Libris, 1983).

Já na próspera e industrializada cidade de São Paulo, foi inaugurada no ano de 1873 a Sociedade Propagadora de Instrução 
Popular cujo objetivo era especializar a mão de obra industrial, essa instituição democratizou o ensino. Em 1882, a Sociedade passa a ser chamada de Liceu de Artes e Ofícios de São Paulo e inicia o ensino profissional voltado às oficinas, comércio e lavoura. Em seu currículo, entre disciplinas técnicas, exatas e artísticas, estava também incluso o ensino de desenho de arquitetura (Costa, 2008).

Com a república o Liceu passa por crises financeiras. No ano de 1895 o engenheiro-arquiteto Francisco de Paula Ramos de Azevedo torna-se diretor e promove grandes reformas no ensino da instituição, como a criação da Escola Politécnica de São Paulo (Costa, 2008).

A criação da Escola Politécnica de São Paulo foi a resposta do Estado e da capital em se adaptarem às mudanças causadas pela Segunda Revolução Industrial e pelas necessidades de realizar melhoramentos urbanos para o desenvolvimento das cidades. Esse contexto criou uma demanda por novas posições em relação ao ensino profissional, principalmente na área de Engenharia Civil e Arquitetura (Caram, 2014).

O primeiro regulamento da Escola Politécnica, em 1894, visava o ensino técnico voltado para a agricultura, a indústria e a construção.
Foram então criados os cursos de engenheiro civil, industrial e agrícola, além de um curso de mecânica para quem não tivesse formação colegial (Costa, 2008).

A partir do segundo regulamento interno de 20 de novembro de 1894, foram criados os cursos de engenheiro-arquiteto, de mecânico e maquinista, como cursos especiais, e vários métodos que superassem as deficiências educacionais de alunos que vinham do ensino secundário, além de evitar a evasão escolar (Caram, 2014). Esse regulamento estabeleceu uma estrutura na qual havia um curso fundamental, dividido em um ano preliminar e dois de curso geral, e os cursos especiais de engenheiro civil, arquiteto, industrial e agrônomo. Essa estrutura permaneceu até o ano de 1931 (Domschke, 2007).

Já no ano de 1896 a Escola de Engenharia do Mackenzie College começa a exercer suas atividades, uma escola particular e sujeita às legislações do Estado de Nova York.

O nascimento, quase no mesmo momento, das duas instituições superiores de ensino de Engenharia, a Politécnica e a Mackenzie, e a reforma do liceu profissionalizante podem ser indicadores da "ideologia de progresso que tinha como uma de suas 
vertentes a institucionalização da formação técnica" (Ficher, 2005, p. 29).

Os projetos apresentados compuseram debates que discutiram o planejamento da Universidade do Rio de Janeiro e da Universidade de São Paulo. No fim da era Vargas, o país contava com cinco universidades: a Universidade do Brasil, a Universidade de Porto Alegre, a Universidade de São Paulo, a Universidade do Distrito Federal e as Faculdades Católicas, embriões da Universidade Católica (Caram, 2014).

Cunha (1983 apud Pinto e Buffa, 2009) afirma que os modelos das instituições de ensino superior no país seguiram, até o final do Estado Novo (1937-1945), os modelos da Europa, depois desse período o modelo seguido foi o dos Estado Unidos.

Durante o período militar (1964-1985) ocorreu a Reforma Universitária e a Lei de Diretrizes e Bases, nos anos de 1968 e 1971, que contribuíram para o retrocesso "nos avanços democráticos e no arranjo multidisciplinar da educação superior" (Godoi, 2014, p. 02).

88 "A cátedra foi substituída pelo departamento, considerado a menor fração da estrutura universitária (Lei 5.540/ 68). Em termos de organização espacial, dar-se-

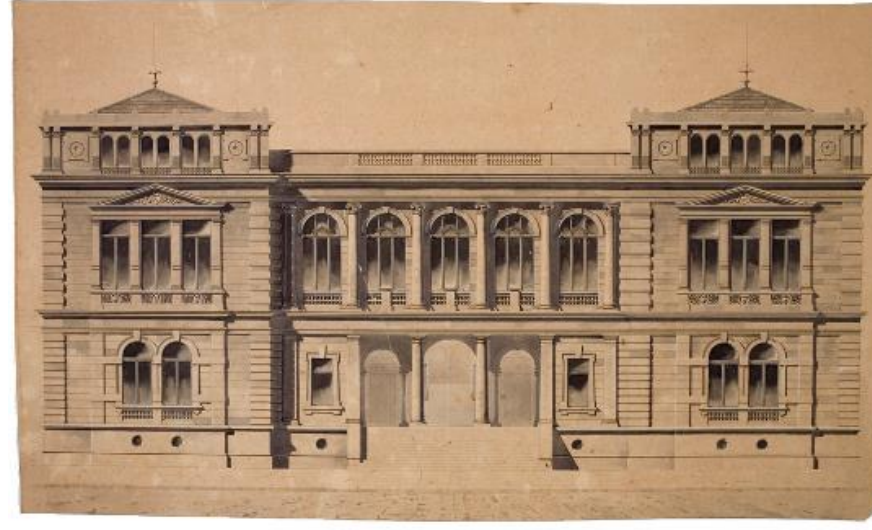

Figura 21- O Edifício Paula Souza, projetado por Ramos de Azevedo e que funcionou entre os anos de 1889-1940, foi o primeiro prédio projetado para a Escola Politécnica, sem data.

(Fonte: http://www.arquiamigos.org.br/info/info21/i-edhist.htm, acessado dia 28 de junho de 2016, as 14:42 horas).

A Reforma Universitária que ocorreu no país em 1968, sob a lei $5.540 / 68^{88}$, retirou o sistema de cátedras que vinha ocorrendo no ensino superior, permitindo, então, a possibilidade de inovação e de amplificação da pesquisa universitária.

Ainda segundo Pinto e Buffa (2009, p. 46): “em 1945, havia 5 universidades no Brasil e, em 1964, já eram 37", aumentaram também os "estabelecimentos isolados (...) de 293 para 564 nesse período"

ia, a partir de então, preferência à construção de câmpus universitários" (Pinto Buffa, 2009, p. 46). 
Com a democracia e a Constituição de 1988 houve a necessidade de criar novas leis para a área da educação.

"A Lei de Diretrizes e Bases (LDB) da educação brasileira foi promulgada com essa finalidade, apenas em 1996 (Brasil, 1996), em substituição à Lei da fase ditatorial de 1971 (Brasil, 1971), após seis anos de discussões, e apresentada pelo então Senador Darcy Ribeiro. A partir dessa Lei, foi constituída a expansão recente da Universidade pública brasileira e paulista" (Godoi, 2014, p. 02).

A expansão das universidades ocorre até os dias atuais, seja nas públicas ou particulares. A USP e outras universidades públicas do Estado de São Paulo são universidades de "grandíssimo porte, ainda que só detêm aproximadamente $7 \%$ das vagas de ensino superior" (Godoi, 2014, p. 04).

Godoi (2014) apresenta os dados de crescimento da Universidade de São Paulo, USP, nos últimos dezoito anos, esse crescimento é semelhante às outras instituições públicas paulistas: a quantidade de alunos de graduação e da pós-graduação subiu 126\%, dando 14,5 alunos por professores, e sua a área construída aumentou $45,5 \%$. 


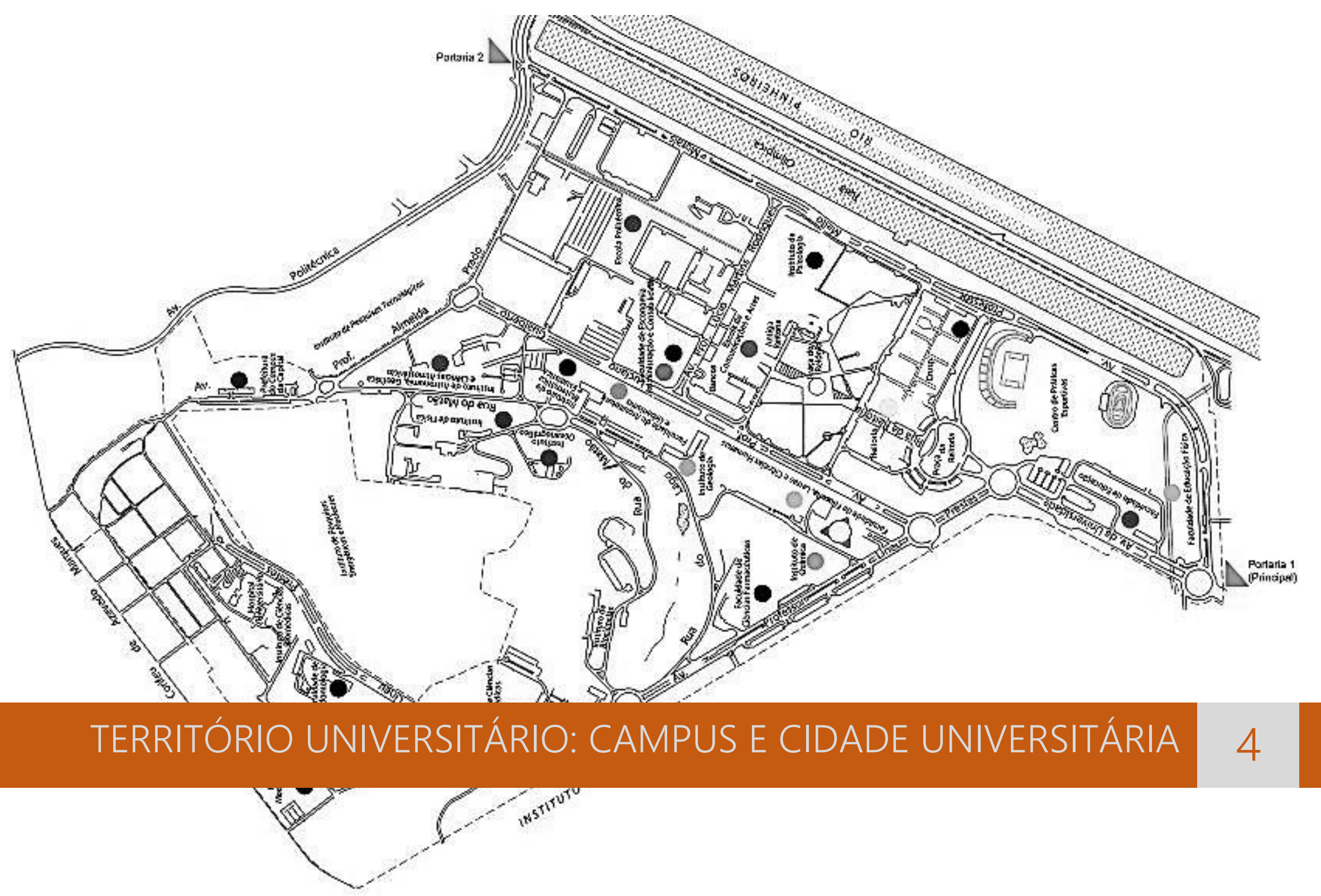


Mapa da Universidade de São Paulo, campus Cidade Universitária, São Paulo.

Fonte da imagem: http://www.nahuhostel.com.br/pt/mapa_usp_imprimir.html (acessado dia 19 de junho de 2016, as 22:16 horas). Editada pela autora. 


\section{TERRITÓRIO UNIVERSITÁRIO: CAMPUS E CIDADE UNIVERSITÁRIA}

Segundo o dicionário Michaelis ${ }^{89}$, Campus significa:

"sm (lat campus) neol 1 Terreno e edifícios de uma universidade, colégio ou outra escola. 2 Parte determinada desse terreno e edifícios, especialmente a área aberta, na parte central do terreno de uma universidade ou outra escola. 3 Universidade, ou outra escola, considerada como entidade educacional, social ou espiritual".

Campus é um termo utilizado pela tradição estadunidense que engloba as áreas das instalações da universidade ou College ${ }^{90}$, incluindo também as residências dos docentes e discentes.

Segundo o documento da Coordenadoria do Espaço Físico da Universidade de São Paulo (2014), esta integração da estrutura física de um campus é importante para o funcionamento da universidade

\footnotetext{
${ }^{89} \mathrm{http}: / /$ michaelis.uol.com.br/moderno/portugues/index.php?lingua=portuguesportugues\&palavra=campus (acessado dia 06 de maio de 2016, as 11:01 horas).

${ }_{90}$ Para Mahler $(2015$, p. 81), o campus contribuiu para a criação de uma "identidade universitária ao reunir todas as instalações de ensino em um território específico, impondo novo significado aos seus atributos culturais e suas interrelações. O termo campus passou (...) a designar o território universitário".
}

como um organismo articulado podendo, também, funcionar para os moldes brasileiros como uma Cidade Universitária.

A definição do termo campus universitário e de Cidade Universitária varia de acordo com o autor e a época; para Dober (1963), Cidade Universitária é compreendida como o território onde está inserida a universidade independentemente de onde está inserida a instituição ou se ela funciona como University ou College ${ }^{91}$; o autor, em 2000, também apresenta o conceito de campus como construções ligadas a espaços livres verdes que permitem a integração do usuário com o espaço.

É preciso compreender o espaço físico de uma instituição de ensino superior como um local onde acontecem as atividades

${ }^{91}$ Godoi (2015, p. 06) explica que University são instituições que "oferecem cursos superiores introdutórios ou profissionais, desenvolvem pesquisas e oferecem estudos pós-graduado", diferente dos Colleges que, nos Estados Unidos, originalmente ofereciam os "cursos introdutórios". 
acadêmicas em si, como o local de aprendizado e como local de identidade institucional.

Para Turner (1995) o termo campus apresenta as ideias de Thomas Jefferson a respeito do planejamento espacial e da educação do período colonial no século XX, ou seja, a ideia de universidades como pequenas comunidades, um microcosmo da sociedade, implantada no campo.

Por fim, o termo campus compreendido pelos britânicos engloba as maneiras não acadêmicas de seus usos, ao contrário da compreensão norte americana de campus como um espaço educacional, atualmente essa diferenciação não é mais utilizada já que ambos possuem semelhanças nos continentes.

"A designação câmpus ou cidade universitária acabou por definir o mesmo espaço, com os mesmos objetivos. Cidade Universitária era, talvez, a aspiração inicial dos primeiros câmpus instalados no Brasil: uma pequena cidade, apartada daquelas que poderíamos chamar de regulares. Esse núcleo teria a capacidade de oferecer ensino, mas também abrigar centros de pesquisa, acolher alunos e professores, proporcionar, enfim, todos os serviços próprios de qualquer cidade. Todavia, isso não aconteceu. Os serviços que os câmpus brasileiros oferecem- mesmo um dos maiores, o da USP- são restritos e deficientes (...). Os câmpus brasileiros não são autossuficientes; dependem ainda, e muito, das cidades em que estão localizados (...). O termo cidade universitária não passa de uma aspiração que nunca se realizou" (Pinto e Buffa, 2009, p. 46-47).

A seguir realiza-se um percurso histórico que liga as primeiras espacialidades aos espaços modernos construídos cuja finalidade é a educação universitária.

\subsection{Dos mosteiros a Bauhaus}

O desenvolvimento da configuração espacial da universidade medieval se deu a partir de atividades realizadas em mosteiros e influenciou aos poucos a sociedade.

Inicialmente, a universidade estava localizada distante das cidades e comunidades para contribuir com a concentração e sua própria autonomia, já suas configurações foram sendo desenvolvidas no decorrer do tempo a partir dos claustros cujas plantas eram quadrangulares. Os mosteiros possuíram diferentes relações com as cidades, sendo afastados inicialmente e, posteriormente, integrados a ela. 
Ribeiro, A. (2008, p. 40-44) pondera sobre o projeto dos monastérios carolíngios, originários da ordenação do pergaminho de S. Gall do ano de 820 d. C, que foram organizados a partir de setores e lembravam uma cidade com ruas que ligavam casas separadas entre si, a proposta era que essa ordem de mosteiro conseguisse se manter de forma autônoma através de moinhos, infraestrutura, padaria, estábulo, espaços para atividades e acomodações próprios; já na Ordem Beneditina, que seguia a de Cluny, a derivante Ordem de Cister possuía um grande pátio que anteriormente segregava os monges dos criados e passou a ser substituído pela "ruela dos conversos".

A Ordem Mendicantes, formada pelas Franciscanas, Dominicanas, Carmelitas e Agostinhas, rompeu o isolamento da Beneditina e passou a usufruir das cidades e nelas difundir os preceitos religiosos. Ainda segundo Ribeiro, A. (2008, p. 49- 50) essa preceptiva tomou forma fazendo desaparecer com as estruturas tradicionais dos "edifícios anexos, armazéns e oficinas. (...) A disposição dos edifícios" não possuía qualquer tipo de modelo e as construções eram implantadas em áreas mais pobres e povoadas, "adaptando os edifícios à malha urbana".

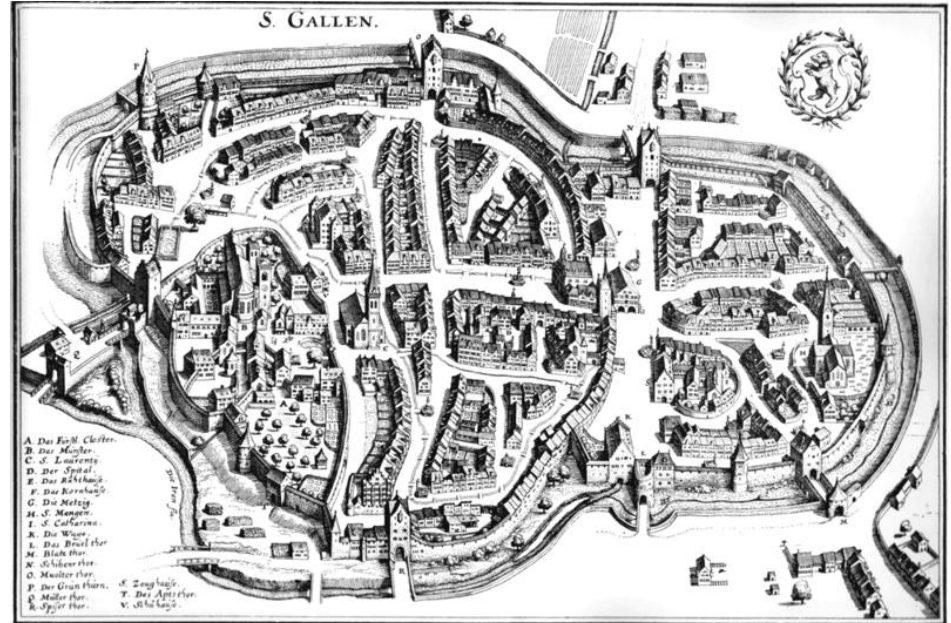

Figura 22- Mosteiro S. Gall que originou os da Ordem Carolíngia, sem data.

(Fonte: Ribeiro, A., 2008, p. 37).

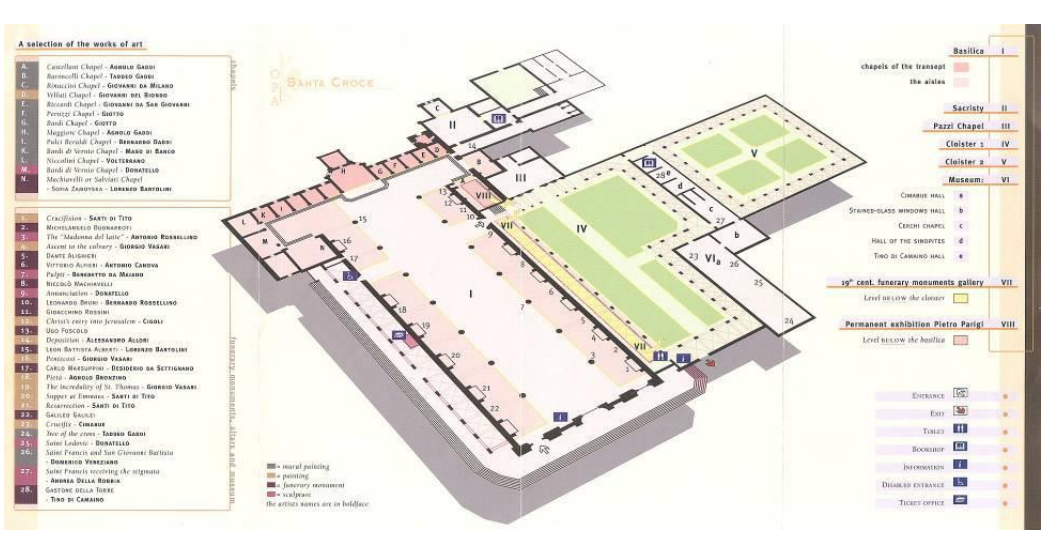

Figura 23- Mosteiro do Santa Croce, Florença, da Ordem Mendicante, sem data.

(Fonte: Ribeiro, A., 2008, p. 50). 
Na França e nos Países Baixos, no século XII, o ensino não estava mais concentrado em mosteiros e sim em escolas anexas às catedrais. Como dito no capítulo anterior, as primeiras universidades ocidentais surgiram da união de escolas e corporações já existentes.

Mahler (2015, p. 73) informa que no final da Idade Média as universidades passaram por um processo aristocrático cujo luxo passou a ser apresentado também em suas construções. "Com o desenvolvimento científico e tecnológico" os prédios das universidades passaram a ser construídos com grande exuberância e mistura de estilos.

A presença de palácios também fez parte da história das universidades italianas e espanholas no período da Renascença, esses palácios possuíam a forma de quadrângulo irregular ou regular enclausurado.

Com o avanço da Renascença, as universidades antigas ou novas adquiriam novos espaços como teatros, salas de reuniões, capelas, bibliotecas e alojamentos. Essas estruturas eram manifestações físicas da forte presença da universidade europeia. A distinta arquitetura e localização urbana das universidades medievais tardias indicam que seu lugar na vida da cidade estava estabelecido.
As cidades universitárias tornaram-se identificadas pela sua presença física no meio urbano (Coulson, Roberts e Taylor, 2010, p. 04).

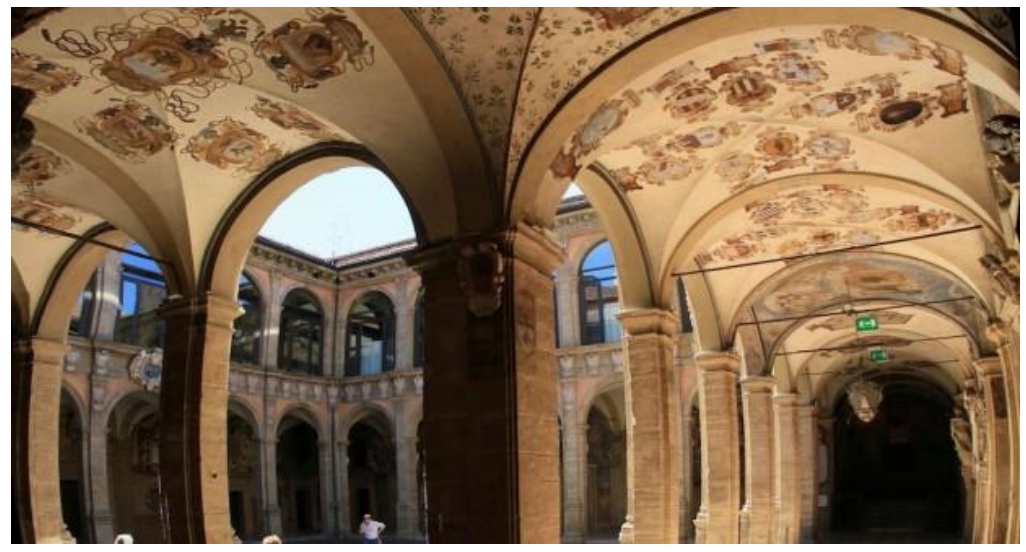

Figura 24- Palazzo dell'Archiginnasio, Universidade de Bolonha, sem data. (Fonte: http://www.cralrer.it/rer/palazzo-dellarchiginnasio/, acessado dia 12 de julho de 2016, as 14:42 horas).

As universidades, então, passaram a contar com faculdades isoladas o que durou até Christopher Wren projetar, de 1660 a 1690, edifícios para as universidades de Oxford e de Cambridge, com plantas que não mais seguiam o quadrângulo fechado e que passaram a ser a nova arquitetura dos Colleges britânicos e futuros modelos estadunidenses (Mahler, 2015).

No século XV a Universidade de Paris estava inserida no tecido urbano, já possuía salas de aulas, alojamentos e igrejas e foi 
adquirindo novos edifícios conforme cresciam os números de alunos;

a composição desta universidade foi tamanha que passou ao tamanho de um bairro, o Quartier Latin, nome esse pela língua oficial da região até 1793: o latim (Mahler, 2015, p. 66). O Quartier Latin configurou

\begin{abstract}
“identidade à região da cidade (...). A implantação na quadra urbana contrapões a rua aos edifícios. A tipologia da quadra fechada, estando relacionada ao ambiente urbano, possibilita a existência de áreas internas coletivas, como praças ou pátios, geralmente contornados por arcadas. Esses espaços são bastante característicos das universidades europeias em todas as etapas de sua existência, desde sua fase medieval até o urbanismo modernista, no século XX. (...) Os bairros universitários inicialmente característicos da Europa continental, existem em diversas outras localidades, nem sempre tendo uma identidade que os destaque em relação a demais bairros da cidade" (Mahler, 2015, p. 67).
\end{abstract}

O primeiro College $e^{92}$ de Paris foi construído por um londrino e era um albergue estudantil; com o tempo e pela "comodidade (...) e

92 O College foi o primeiro edifício especializado e totalmente voltado para as atividades universitárias, mas ainda seguindo os modelos dos monastérios. Willis e Clark (1886) ainda frisam que os collegiuns não tinham qualquer relação com os prédios adjacentes.

${ }^{93}$ Segundo Pinto e Buffa (2009, p. 31-32), o College foi inspirado nos claustros medievais e "a planta dos Colleges adotou o quadrado (quadrangle ou quad) como espaço articulador de todo o edifício. Tratava-se, nesses claustros, de um retângulo também para poupar tempo e dinheiro" os docentes também passaram a viver neste local. Isso ocorreu muito e fez com que os Colleges passassem a ser espaços de ensino (Mahler, 2015, p. 66).

College 93 passou a ser designado como a espacialidade acadêmica e, segundo Mahler (2015, p. 67), apesar de "separado por muros, esse ambiente cresceu integrado ao tecido urbano".

A "ideia de universidade" passou a ser mais independente no decorrer da história e suas estruturas físicas sofreram interferências de acordo com os períodos históricos descritos no capítulo anterior. Segundo Ribeiro, A. (2008, p. 57), as mudanças ocorreram, pois, as universidades passaram a se tornar dependentes das cidades onde estavam.

Esse fato ocorreu na Universidade de Cambridge que foi inédita em sua configuração de pátios voltados para a cidade o que marcou uma nova situação urbana (Ribeiro, A., 2008, p. 57).

ou quadrado cercado por arcadas sob as quais a circulação era livre, abertas nas laterais e cobertas. Nos colleges, o quadrângulo é um espaço cercado de edifícios, usualmente de dois andares, com um gramado simples no centro e circulação aberta ao seu redor. Na maioria das escolas, esse espaço de circulação e de lazer era destinado aos alunos mais adiantados (seniors) e permitia acesso interno a todos os edifícios". 
Oxford, no entanto, foi mais conservadora e utilizou do gótico "quad fechado (...) até o século XVII" (Mahler, 2015, p. 69).

Para Turner (1995) o desenvolvimento arquitetônico dessa universidade mostrava as ideias intelectuais e a abertura de uma de suas faces foi, para o autor, um desenvolvimento natural na estética renascentista vigente na qual o quadrado medieval, até então utilizado, foi substituído por uma organização axial que sugeria uma abertura do College ao mundo exterior.

Esse pátio de três faces foi vital para o planejamento universitário nos Estados Unidos.

Oxford e Cambridge foram criadas em pequenos terrenos e suas expansões ocuparam seus perímetros; conforme novos eram construídos ou os antigos, ampliados, o terreno aonde ser construído passou a ser escasso. Segundo Pinto e Buffa (2009, p. 33), é importante observar que esses edifícios possuíam um "caráter urbano" deixando de ser "implantados nos limites das cidades", os novos cursos passaram a utilizar edifícios já existentes nas cidades e terminam por se transformar em universidades.

94 “O território da escola definia-se por seus edifícios, e não por (...) uma área delimitada, fechada e apartada da cidade. As escolas se integravam à malha urbana e constituíam elementos de seu crescimento (...) o limite da escola (...) era seu
As universidades de Cambridge e Oxford definiram uma região e as construções passaram a fazer parte da própria universidade, apesar de inseridos na malha urbana. Esse fator, segundo Pinto e Buffa (2009), da relação do espaço universitário com a cidade, ocorreu em praticamente todos os outros países europeus ${ }^{94}$.

Turner (1995) apresenta essa tradição britânica de construção de espaços universitários que foi levada para os Estados Unidos e adaptada, para o que atualmente é conhecido por campus.

A evolução dos modelos construídos para as atividades universitárias foi modificada e desenvolvida a partir da compreensão da importância desses espaços e por seus entornos, além das relações entre o campus e esses outros edifícios vizinhos (Mahler, 2015).

próprio edifício e, ao redor, a cidade fluía e crescia livremente" (Pinto e Buffa, 2009, p. 34). 


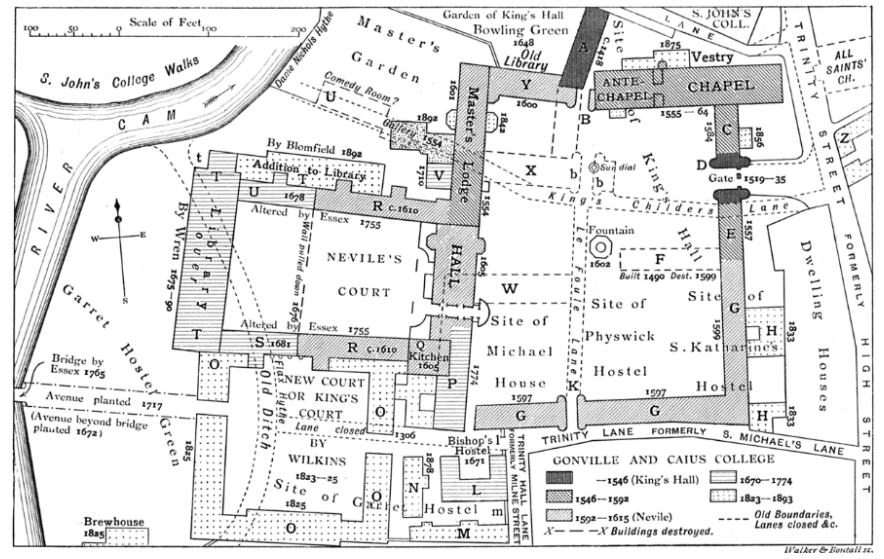

Figura 25- Planta histórica do desenvolvimento do Trinity College, Cambridge, 1897.

(Fonte: https://en.wikipedia.org/wiki/Trinity_College,_Cambridge, acessado dia 11 de julho de 2016, as 22:46 horas).

Para compreender os espaços ocupados pelas universidades ao longo da história, assim como suas evoluções, é preciso considerar o movimento moderno como fator de ruptura com os modelos arquitetônicos e urbanísticos anteriores e condizente com a sociedade pós-industrial que abolia o ornamento e visava a racionalidade na função de um edifício.

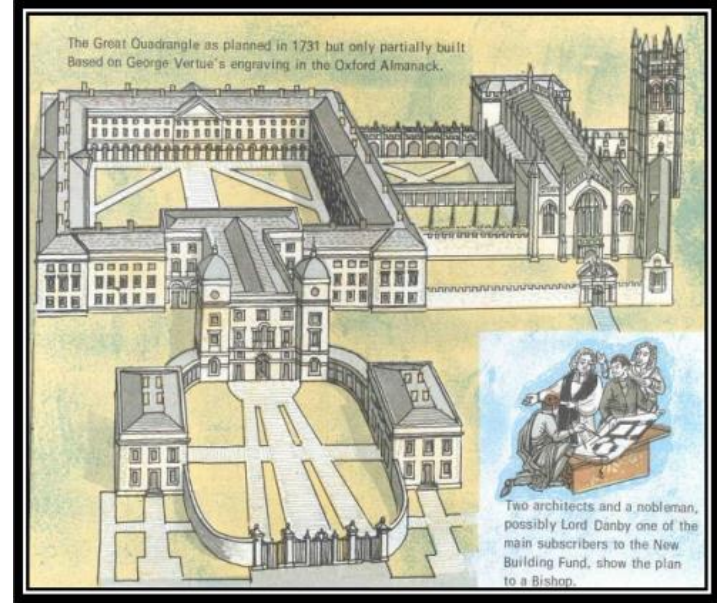

Figura 26- Vista do quadrangle, Universidade de Oxford, sem data. (Fonte:

http://www2.faced.ufu.br/colubhe06/anais/arquivos/519GelsonAlmeidaPinto_Est erBuffa.pdf, acessado dia 14 de julho de 2016, as 15:49 horas).

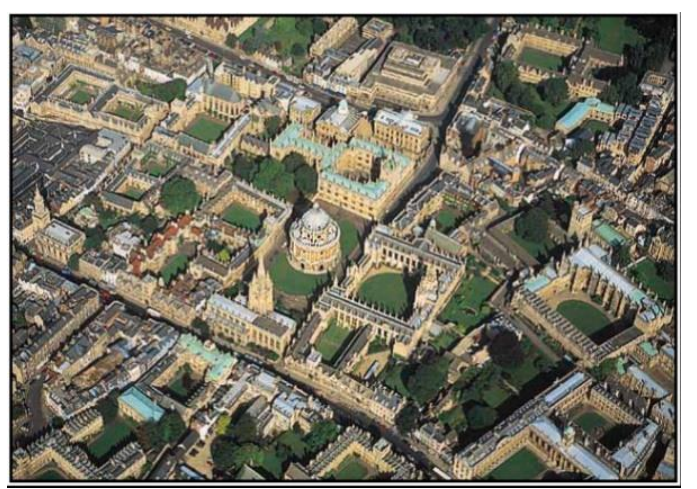

Figura 27- Vista aérea da Universidade de Oxford, sem data. (Fonte:

http://www2.faced ufu.br/colubhe06/anais/arquivos/519GelsonAlmeidaPinto Est erBuffa.pdf, acessado dia 14 de julho de 2016, as 15:49 horas). 
A Europa passou pela transição entre o academicismo e a ruptura representada pelo moderno, nesse momento a Bauhaus foi um espaço de experimentações pedagógicas englobando as novas técnicas e estéticas modernas, configurando a formação do homem dessa época (Arcipreste, 2012). A Escola tinha uma íntima ligação com o Movimento Arts and Crafts e a Deutscher Werkbund ${ }^{95}$, seus precursores, e ainda hoje, muitos dos objetos criados na Escola permanecem atuais em consequência do uso da modernidade descomprometida em seu design.

A Bauhaus, cujo significado é 'construir a casa', foi uma importante Escola localizada na Alemanha que formou cerca de quinhentos alunos. Fundada em 1919 pelo arquiteto modernista Walter Gropius, a Escola viveu e sobreviveu por quatorze anos a diferentes mudanças políticas e econômicas (Farthing, 2011). Gropius assumiu a direção da Escola Superior de Belas Artes de Weimar, fundada por Henry van de Velde, em março de 1919, e a uniu à Escola de Artes e Ofícios, fundando a Staatliche Bauhaus Weimar.

\footnotetext{
95 Pode ser traduzido como 'Federação Alemã do Trabalho', fundada por arquitetos, designers e empresários alemães no ano de 1907. O Movimento era experimental e abrangia desde o projeto em muitas escalas, da casa até o da xícara de café, disseminando ideias estéticas inéditas que fossem populares e acessíveis.
}

O prédio da Bauhaus em Dessau, em 1925, projetado por Gropius seguia a arquitetura moderna; a funcionalidade do edifício seguia o programa proposto e era dividido pelos "espaços acadêmicos, áreas administrativas e dormitórios estudantis", os professores ficavam em outro prédio afastado (Mahler, 2015, p. 75).

O edifício utilizava de pilotis para manter a relação do prédio com a paisagem, fator este que influenciou outras universidades. A Bauhaus marca a ruptura com o clássico e seu resultado é a exposição de como o prédio funciona, a partir de pavilhões, simetrias e mescla de volumes. A própria revolução pedagógica ${ }^{96}$ da escola permitiu a construção de um edifício que também fosse revolucionário.

\footnotetext{
${ }^{96} \mathrm{O}$ arquiteto compreendia que a Bauhaus deveria se apoiar em bases científicas, assim, a pedagogia foi articulada no ideário teórico do Escolanovismo "que sistematiza a metodologia da problematização, como caminho para o 'aprender a-aprender"' (Arcipreste, 2012, p. 76).
} 


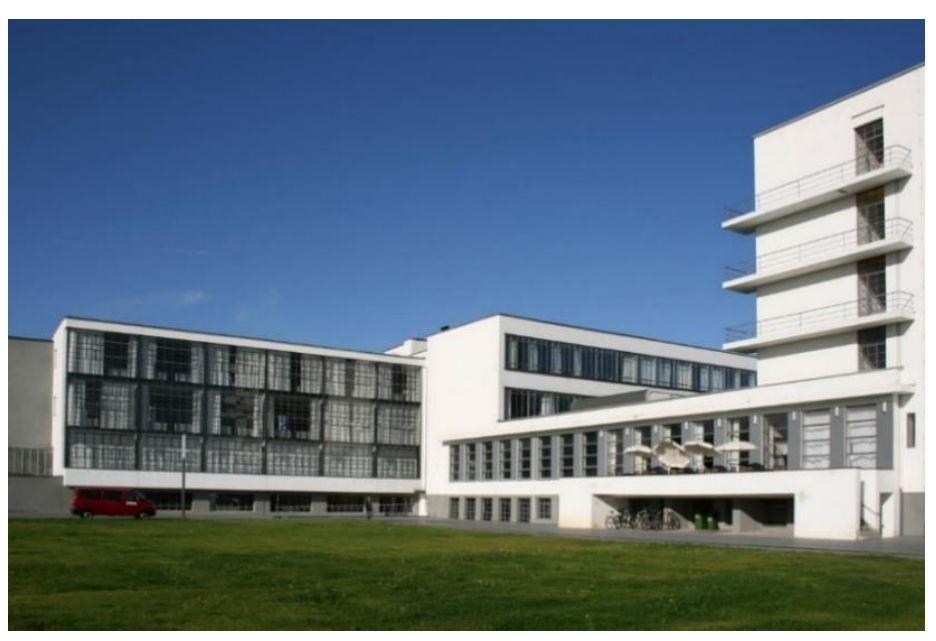

Figura 28- O prédio da Bauhaus, Dessau, sem data. (Fonte: http://www.germany.travel/en/media-gallery/gallery-detailbauhaus-and-its-sites-in-weimar.html, acessado dia 12 de julho de 2016, as 15:25 horas).

Com o exílio dos professores para outros países na Segunda Guerra Mundial pelos nazistas, as ideias da Bauhaus continuaram a influenciar e ser disseminadas por outras instituições de ensino superior. Destaca-se sobretudo os Estados Unidos onde Gropius foi recebido por Harvard e Mies van der Rohe, pelo Instituto de Tecnologia de Massachusetts, o MIT.
4.2. A concepção de uma nova comunidade acadêmica: o desenvolvimento de Campi

Algumas instituições de ensino superior nos Estados Unidos mantiveram em seus nomes o termo College por justificativa e respeito à história. Os Colleges e universities americanos sempre foram como pequenas cidades ou comunidades com suas próprias características que diferem seu modelo dos europeus já que passaram também a contar com "dormitórios, refeitórios e espaços recreativos" (Pinto e Buffa, 2009, p. 36).

Segundo Turner (1995), os Estados Unidos começaram a criar seus espaços universitários a partir de Colleges afastados um dos outros, permitindo que cada faculdade tivesse sua própria autonomia. Outra característica distinta da europeia que ocorreu no novo continente foi a localização dos Colleges nos campos ou limites urbanos, eram escolas implantadas junto à natureza; os Colleges americanos, desde seus primórdios, deixaram de lado a ideia do claustro fechado passando a buscar a implementação de seus 
edifícios em espaços verdes, mesmo criados, que contivessem algum tipo de água como um rio ou lago, um espaço rural ${ }^{97}$.

Esse fator contribuiu também para novas experiências em urbanismo até antão desconhecidas: a concepção de uma comunidade acadêmica.

Essa nova interpretação da concepção espacial, para Turner, tinha motivos religiosos pois os puritanos compreendiam os quads monásticos como descendentes da fé católica. Harvard, por exemplo tinha o pátio aberto para a rua, mas com conjuntos de edifícios separados entre si, planejamento este que rompe de vez com a imagem da clausura católica.

A diversidade arquitetônica e urbanística é uma característica importante dos Colleges coloniais cujas plantas originais diferiam das outras obras do período.

Na construção do College de Harvard, a partir de 1636, foram elaborados experimentos do que viria a ser seu campus. A planta do antigo College era em forma de E com uma torre em seu bloco

${ }^{97}$ A diferença da implantação de um College britânico e um campus estadunidense é que o primeiro se expandiu pelas cidades e a influenciou, enquanto o segundo era "antiurbano com uma estrutura autossuficiente. As universidades da América Latina "constroem o espaço universitário no âmbito de um sistema socialmente segregado, e de uma mentalidade de isolamento da população universitária, principal, em 1655 a universidade já contava com quatro prédios espalhados ${ }^{98}$ (Godoi, 2015).

localizando suas universidades em áreas de expansão da cidade" (Mahler, 2015, p. 96).

${ }^{98}$ Godoi (2015) ainda explica que o espaçamento entre os edifícios era para evitar o risco de alastrar possíveis incêndios entre os prédios, já que eram construídos com madeira. 


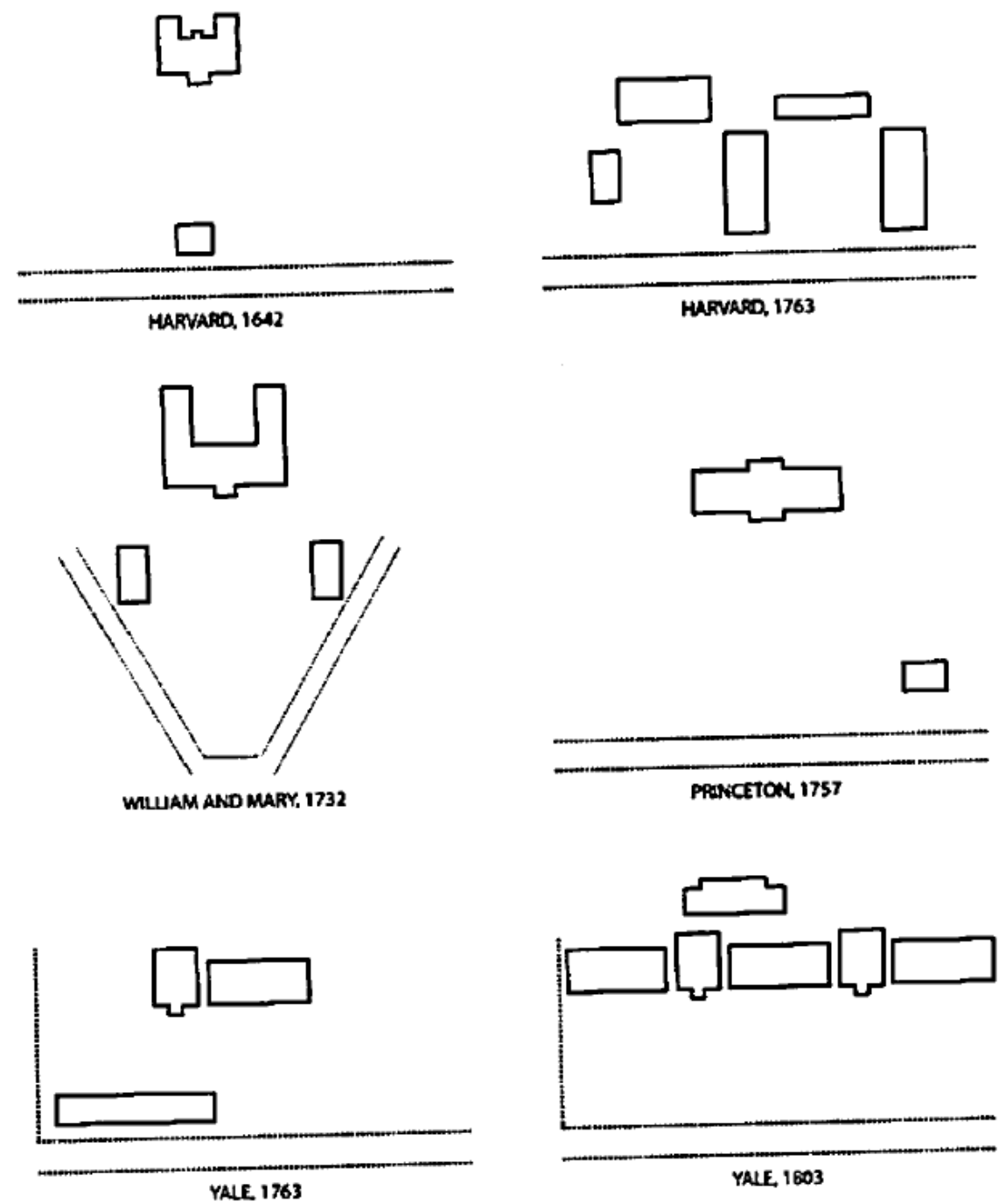

Figura 29- Primeiros projetos de Colleges estadunidenses (Harvard, William and Mary, Princeton e Yale).

(Fonte: Coulson, Roberts e Taylor, 2010, p. 09).

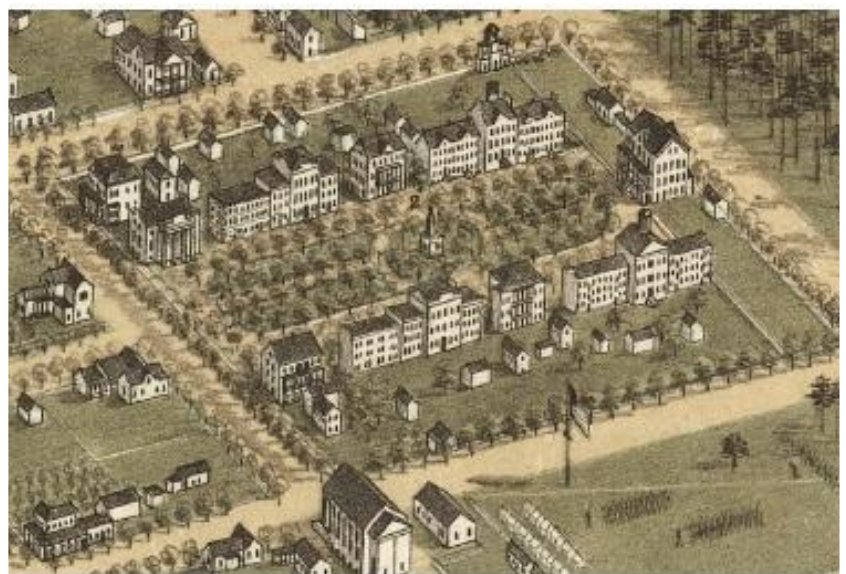

Figura 30- Universidade da Carolina do Sul, 1872. (Fonte: Ribeiro, A., 2008, p. 61).

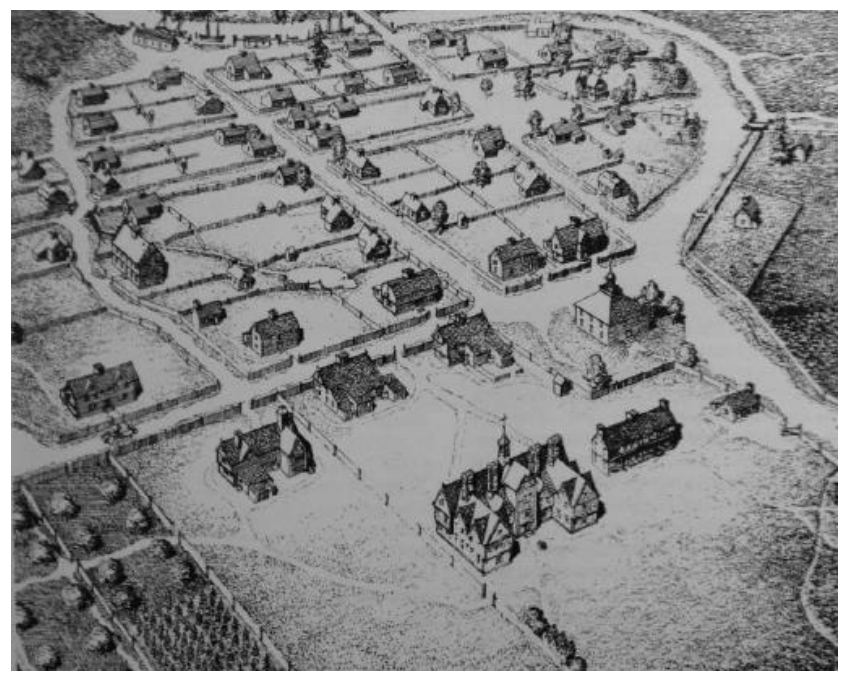

Figura 31- Ilustração da cidade de Cambridge, EUA. No primeiro plano estão os edifícios da Universidade de Harvard, 1668.

(Fonte: Turner, 1995, p. 25). 
O Yale College foi influenciador de outras plantas de prédios universitários. E seus edifícios foram projetados para serem imponentes (Turner, 1995).

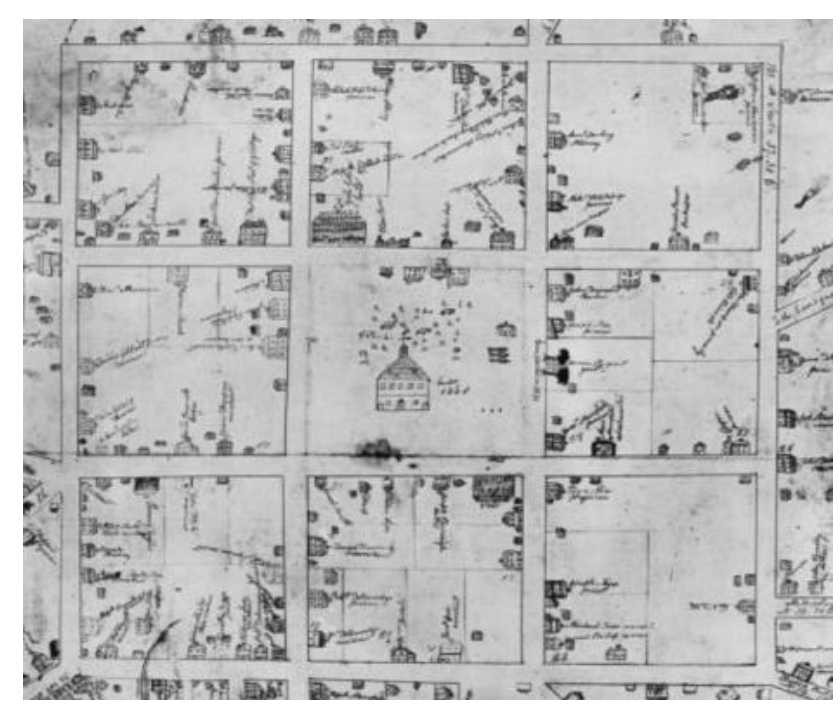

Figura 32- Plano de New Haver em Connecticut. O primeiro College de Yale do lado superior esquerdo, 1748

(Fonte: Turner, 1995, p. 39).

A universidade de Princeton tinha seu edifício como "pano de fundo" para a vegetação, um padrão que foi seguido por Rhode Island, Dartmouth e Rutgers. Esse College foi, talvez, o primeiro a ser

99 "Last week to show our patriotism, we gathered all the sterward's winter store of tea, and having a fire in the Campus, we there burnt near a dozen pounds (...)". construído em uma área totalmente rural, entre dois rios e largas plantações (Mahler, 2015, p. 88).

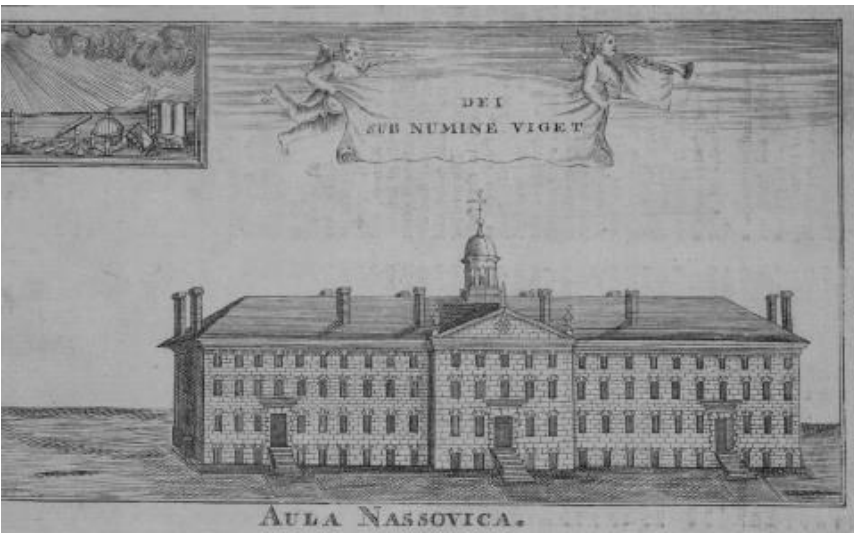

Figura 33- Nassau Hall, Universidade de Princeton, 1760 (Fonte: Mahler, 2015, p. 89).

Segundo Turner (1995, p.47) o primeiro uso do termo campus foi em uma carta de um aluno de Princeton, em 1774, em que narra eventos do Boston Tea Party:

"Na semana passada para mostrar nosso patriotismo, reunimos todos o estoque da loja de chá, e fizemos uma fogueira no Campus, nós queimamos aproximadamente uma dúzia de libras (...)". ${ }^{99}$ 
A partir de 1820, o termo passa a ser empregado em outras instituições. Campus, então, passou a ser utilizado pelos espaços apropriadas pelos Colleges estadunidenses (Turner, 1995).

Após a Guerra Civil, em 1865, aumentou o número de escolas práticas voltadas ao ensino agrícola, técnico e artístico. Essa nova proposta de ensino, apresentada através do Morril Act, acabou mostrando que mudanças eram necessárias no planejamento físico e arquitetônico, o responsável por essas inovações foi Frederic Law Olmsted.

Segundo Schenk (2008), durante os anos e através de textos e planos, construídos ou não, Olmsted amadurece suas ideias e tenta coloca-las em prática no planejamento do campus de Berkeley, Califórnia, incluindo também sua vizinhança. Segundo Olmsted,

"a função primeira de um campus (é) intensificar a qualidade da vida rural. Para que um College treine com sucesso o homem civilizado, o campus deveria assemelhar-se a um 'modelo de vizinhança rural' ou comunidade" (Schenk, 2008, p. 116).

O plano de Olmsted era integrar desenho e projeto à natureza de forma orgânica, permitindo o crescimento da universidade sem

"destruir a beleza da totalidade. (...)Para Frederick Law Olmsted, a relação entre homem e natureza (...) é vital para a sanidade humana" (Schenk, 2008, p. 117).

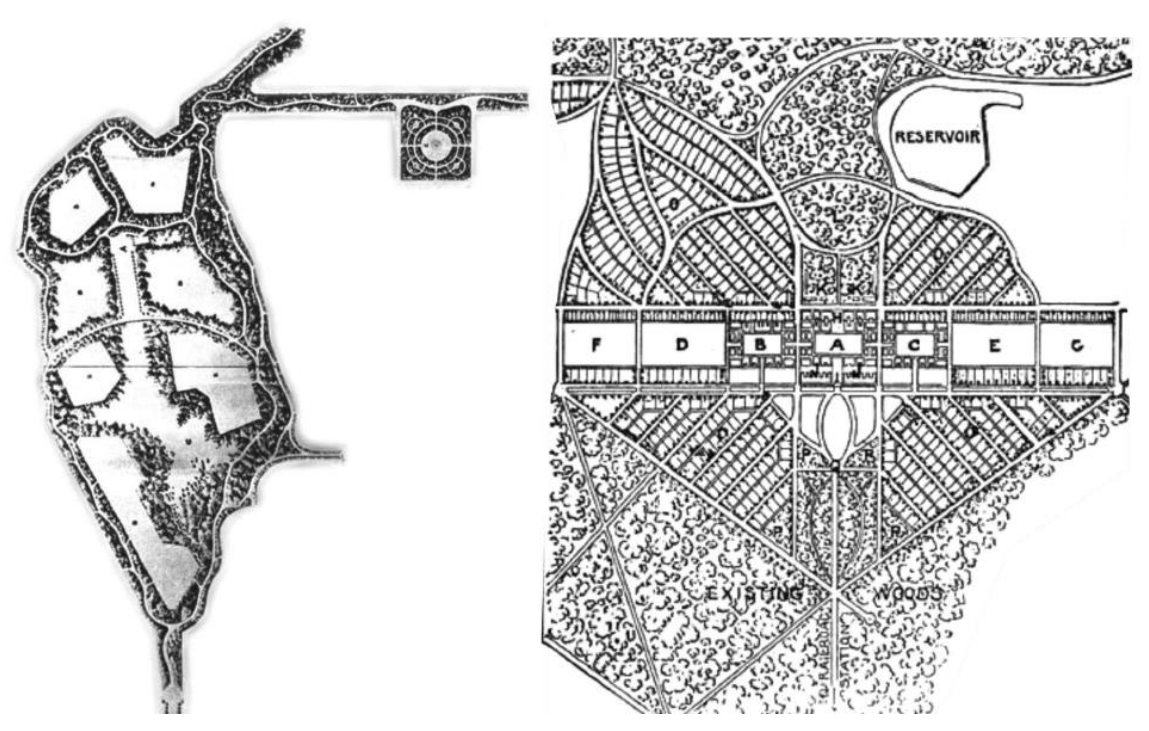

Figura 34- Esquerda: Campus de Berkeley, sem data. Direita: Plano diretor da Standford University, projeto de Olmsted e Coolidge, 1888.

(Fonte: Mahler, 2015, p. 95).

Olmsted pensou em uma comunidade ampla e unida, pensando também na paisagem como parte do projeto de campus, para Ribeiro, A. (2008, p. 64):

"o novo desenho se distinguia através de um parque de aspecto bucólico (...), formal e simétrica, os prédios eram dispostos de modo irregular e pictórico. Ao invés da existência da área central ao qual se subordinavam as edificações, predominava uma disposição informal onde os elementos eram tratados como entidades autônomas, e o espaço que os envolvia era qualificado por sua natureza contínua, infinita, não delimitada ou particularizada pela disposição dos edifícios". 
A natureza tem uma presença importante nos campi do século XIX, era importante que os espaços universitários estadunidenses fizessem parte da localização e do planejamento, ao contrário do que aconteceu na Europa (Turner, 1995).

Os projetos de campi sofreram alterações de país para país, como serão apresentados nos próximos tópicos.

4.2.1. Jefferson e a Universidade de Virgínia: o modelo do planejamento de campus

A Universidade de Virgínia foi fundada por Thomas Jefferson em 1819. Thomas Jefferson foi grande pensador, principal autor da Declaração de Independência dos Estados Unidos da América, governador de Virginia e presidente do país.

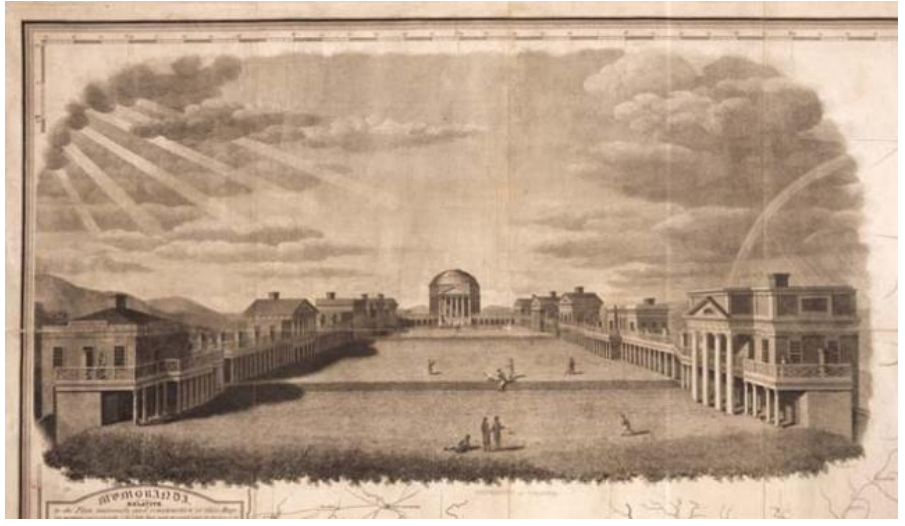

Figura 35- Vista do Campus de Virgínia, sem data. (Fonte: Pinto e Buffa, 2009, p. 39).

Essa universidade foi diferente das restantes pois além de pública, ela buscava oferecer um ensino "separado da doutrina religiosa, o que fez com que o lugar de destaque de seu câmpus fosse a biblioteca e não mais a igreja" (Pinto e Buffa, 2009, p. 37). Foi a universidade que teve o primeiro projeto completo de campus.

“Um eixo no sentido norte-sul, traçado na planta de uma antiga fazenda, foi a base do projeto do câmpus dessa universidade. No final dessa linha, ao sul, foi definido o local da biblioteca; perpendicularmente a ela, diversos outros eixos estabeleceram o local dos demais edifícios que comporiam o câmpus. Estava determinado mais um novo e inédito espaço para o ensino e o aprendizado: o câmpus universitário. Uma iniciativa inédita no que se refere tanto aos planos educacionais quanto ao espaço destinado à formação 
universitária e que, posteriormente, foi repetido por todos os EUA e, em proporções mais modestas, em outros países" (Pinto e Buffa, 2009, p. 37- 38).

O projeto era muito diferente do que era feito na Europa e no Reino Unido. O campus era extenso e possuía toda a infraestrutura que uma cidade possui.

Pinto e Buffa (2009) explicam que no eixo principal na parte sul foi construída uma biblioteca seguindo o Panteão Romano, mas em menor escala, é a rotunda.

\begin{abstract}
"No final de cada um dos eixos perpendiculares implantou-se um edifício. Um de cada lado do eixo (...) os prédios ficavam separados por um largo jardim, um lawn, gramado entremeado por arranjos paisagísticos ao longo dessa extensa avenida verde (...). De cada lado do lawn e passando pela frente dos edifícios, ruas levavam até a rotunda implantada majestosamente no final do conjunto. No início, toda a circulação se fazia por uma loggia, caminho abrigado que passava pela frente de todos os prédios; posteriormente foram abertas as ruas" (Pinto e Buffa, 2009, p. 38).
\end{abstract}

Inicialmente era proposto que ao lado de cada edifício de aulas tivesse um alojamento de alunos e docentes, separados por jardim. Cada prédio do campus era destinado para uma atividade diferente (Pinto e Buffa, 2009).

O estilo arquitetônico escolhido inicialmente para ser utilizado em todo o campus foi o coríntio, mas pela dificuldade em ensinar os escravos a esculpir as colunas, a ordem adotada acabou sendo a jônica (Benevolo, 2014, p. 212).

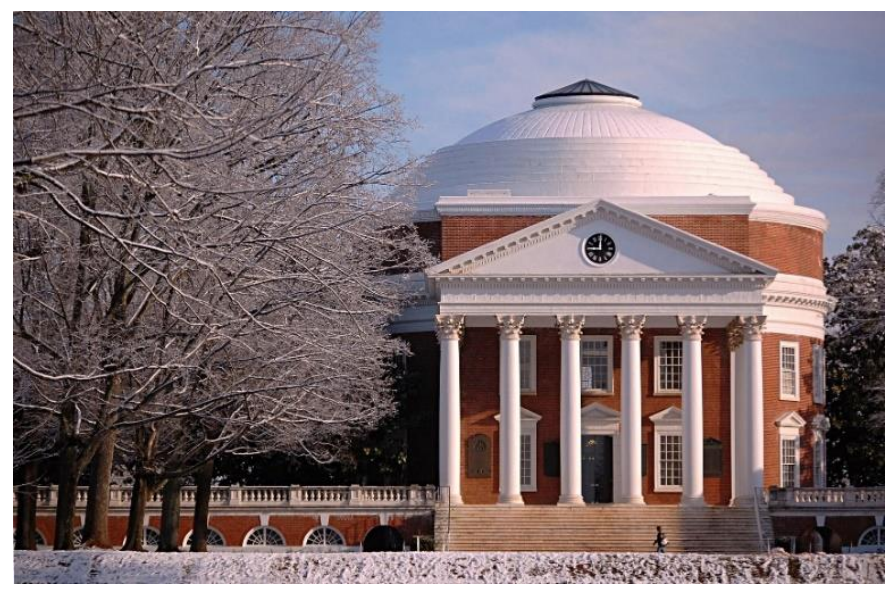

Figura 36- Rotunda, Campus de Virgínia, sem data.

$$
\text { (Fonte: }
$$

http://revistagalileu.globo.com/Ciencia/Psicologia/noticia/2014/03/universidadeda-virginia1.html, acessado dia 14 de julho de 2016, as 16:10 horas).

Segundo Mahler (2015), os campi da Carolina do Sul, Yale e Harvard podem ter sido utilizados como fontes das ideias de Jefferson para Virgínia. Esse projeto de campus serviu de modelo para outras universidades como a Duke University, a Johns Hopkins, a Rice University e a Vanderbilt University. 


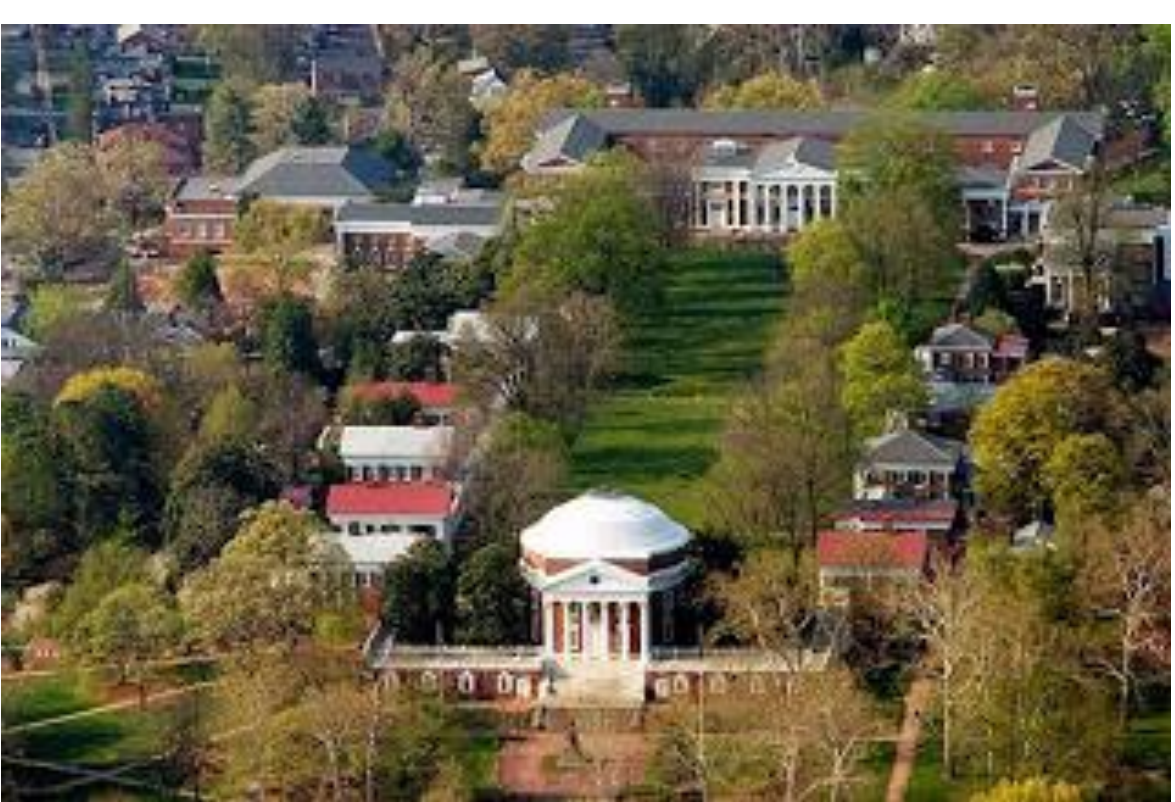

Figura 37- Vista aérea do campus de Virgínia, sem data. (Fonte: http://elimarcristina.blogspot.com.br/, acessado dia 14 de julho de 2016, as 16:10 horas).

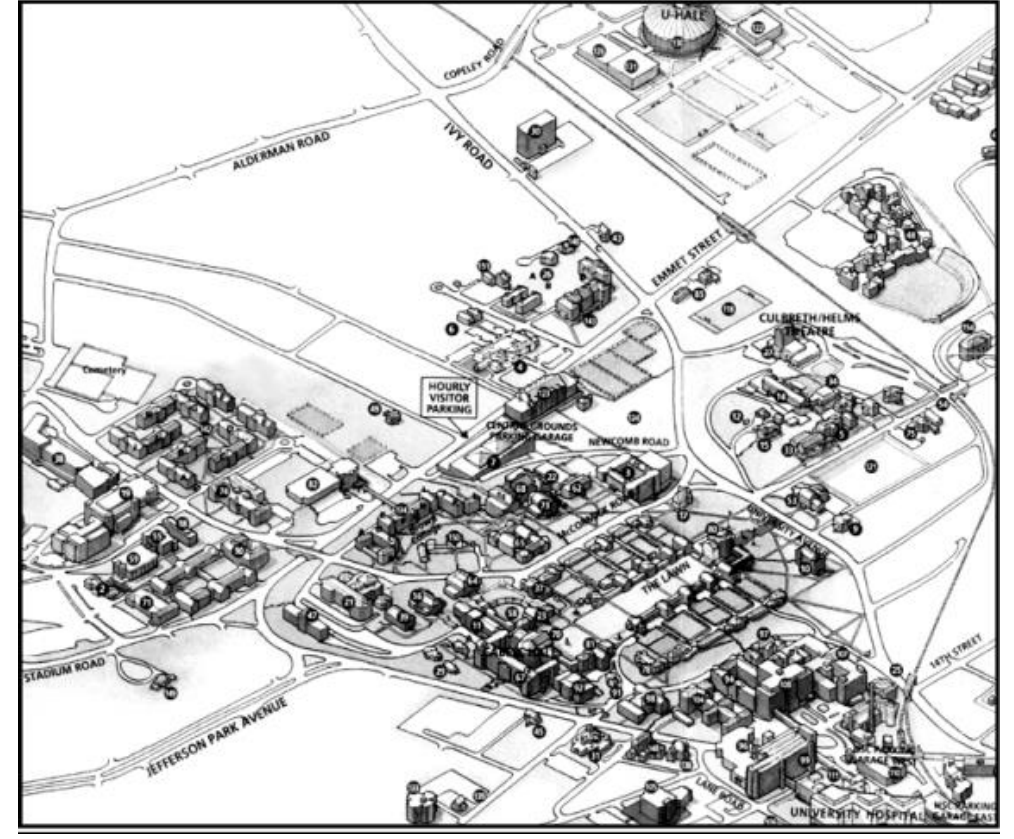

Figura 38- Mapa atual do campus de Virgínia, sem data. (Fonte:

http://www2.faced.ufu.br/colubhe06/anais/arquivos/519GelsonAlmeidaPinto_Est erBuffa.pdf, acessado dia 14 de julho de 2016, as 16:10 horas). 
4.2.2. Illinois Institute of Technology: a continuação das ideias de Mies Van der Rohe e da Bauhaus

O Instituto de Tecnologia de Illinois nasce em 1940 a partir da junção do Lewis Institute, fundado em 1895, e do Armour Institute, criado em 1890.

O arquiteto modernista Mies Van der Rohe teve um importante papel para a formação dessa universidade. A Bauhaus havia sido fechada pelos nazistas e Mies passou a buscar por um local onde poderia continuar a aplicar suas ideias que foram iniciadas na Alemanha; Chicago recebeu suas convicções com bastante abertura (Mahler, 2015).

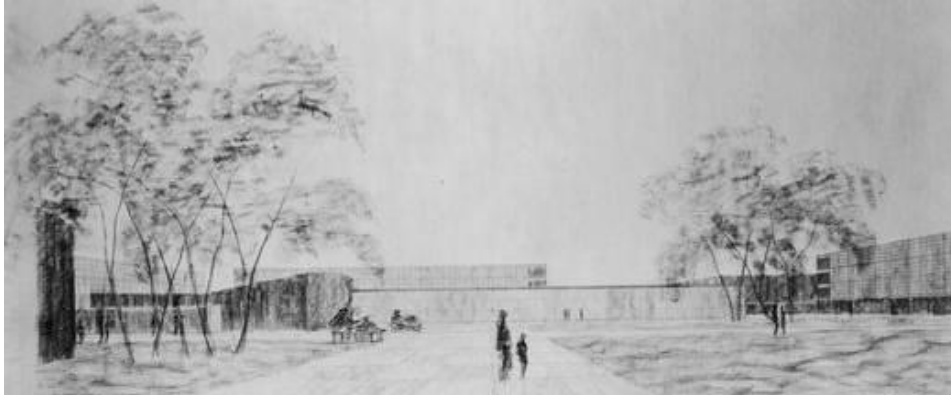

Figura 39- O primeiro estudo realizado para o IIT, sem data. (Fonte: Ribeiro, A., 2008, p. 124).

Foi em 1938 que o arquiteto aceitou dirigir o departamento de arquitetura do Instituto Armour ${ }^{100}$. É possível dizer que o IIT, Illinois Institute of Technology, "nasceu, depois da II Guerra, uma das melhores expressões da arquitetura moderna estadunidense" (Ribeiro, A., 2008, p. 112). O arquiteto, além de transformar o curso de arquitetura, projetou o campus do IIT.

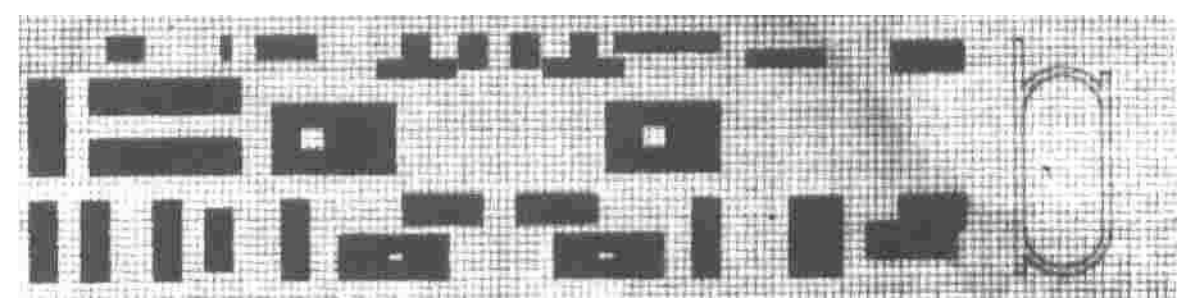

Figura 40- Projeto final do campus, sem data. (Fonte: Benevolo, 2014, p. 627).

${ }^{100}$ Ele foi diretor do departamento de 1938 a 1958 e "estabeleceu um currículo baseado na filosofia bauhausiana de sintetizar estética e tecnologia" (Mahler, 2015, p. 97). 


\section{As mudanças levadas ao Instituto Armour retratam a trajetória} da carreira de Mies como acadêmico através de seu período na Bauhaus e as influências de outros professores como Gropius, Klee e Kandinsky. $\mathrm{O}$ arquiteto também diz que outra influência foi o projeto de Jefferson (Ribeiro, A., 2008).

Para o projeto, então, Mies utilizou da "pureza das formas e dos materiais - "less is more", isento de ornamentos. O projeto também tem a proposta de se integrar naturalmente com a cidade, "livre de portões ou muros" (Ribeiro, A., 2008, p. 113- 114).

“No primeiro esquema, de 1939, as várias seções estão agrupadas em poucos blocos de construção, dispostos simetricamente em torno de um vasto espaço fechado atravessado por uma rua axial, contudo, enquanto a simetria é rigorosa no ambiente central, nas margens aparecem alguns desvios cometidos que tiram a rigidez do conjunto e preparam os anexos com as áreas circundantes. No projeto seguinte, de 1940, devendose conservar uma segunda rua que cruza com a primeira no centro do local, perde-se o quadrado fechado do ambiente central e a composição torna-se mais articulada. Por último, Mies abandona toda tentativa de subordinar o conjunto a um quadro visual unitário, entremeia a composição com uma retícula modular e coloca as várias seções em muitas construções separadas, distribuídas livremente no amplo espaço uniforme" (Benevolo, 2014, p. 624).
Mies recebeu uma área de 485.000 m2 para desenvolver o campus (Ribeiro, A., 2008).

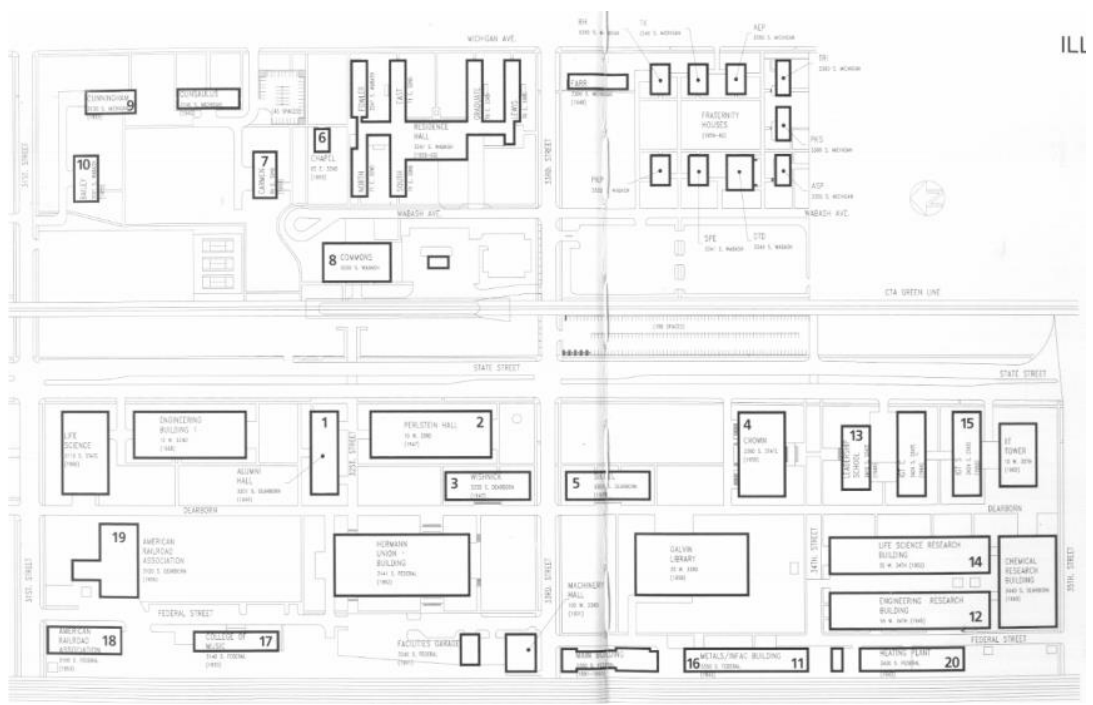

Figura 41- Planta do campus com as obras de Mies Van der Rohe em destaque, sem data.

(Fonte: Ribeiro, A., 2008, p. 138).

O espaçamento executado entre os edifícios garantiu ritmo e flexibilidade aos futuros projetos do campus. O resultado do projeto foi um campus com uma arquitetura moderna e tecnológica para o período, utilizando de materiais como vidro, aço e concreto, totalmente integrado na malha urbana. O campus torna-se "um 
fragmento de cidade ideal, onde cada aspecto (...) está submetido a um controle inflexível" (Benevolo, 2014, p. 626).

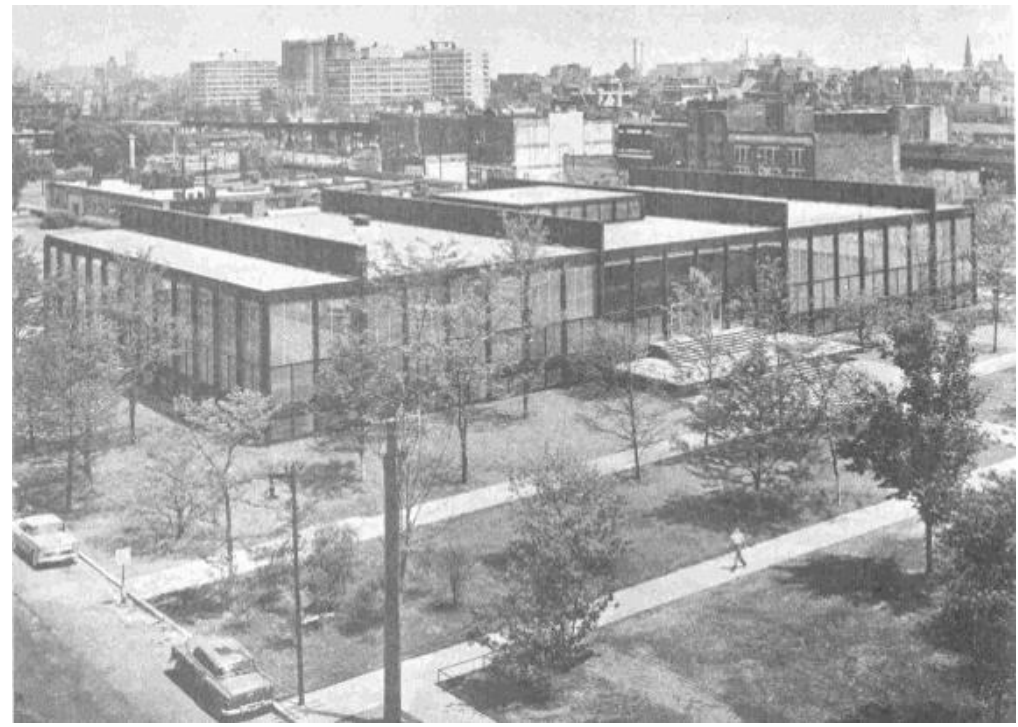

Figura 42- Crown Hall de 1955, IIT, sem data. (Fonte: Benevolo, 2014, p. 627).

${ }^{101}$ Essas comunidades vão além dos campi universitários, podendo ser levada para qualquer outro local no qual o conceito de propriedade privada tenha sido revisto, como em hospitais ou cooperativas.
4.2.3. Christopher Alexander e a Universidade de Oregon: o campus como uma experiência de projeto participativo

Um importante expoente no planejamento de campus no período pós-guerra dado ao seu caráter inovador foi Christopher Alexander na Universidade de Oregon, em Eugene, no ano de 1969.

Em seu livro 'The Oregon Experiment' (Alexander et al., 1979) o autor explica sobre sua experimentação no planejamento do campus de Oregon, o que se tornou uma importante teoria dentro do campo de arquitetura e do desenho urbano. Neste livro ele apresenta o plano geral do campus afirmando ser possível de adaptá-lo a outras comunidades ${ }^{101}$ de qualquer local do mundo, com pequenas modificações.

Para o arquiteto o projeto deve mesclar usos e considerar as discussões da comunidade, indo além do ato particular de projetar e construir. Foi proposta que no lugar do tradicional Plano Diretor houvesse uma cartilha de seis princípios nos quais o projeto e novos paradigmas do campus se apoiariam: a comunidade acadêmica, 
organizada em grupos, iria conceber os espaços livres e os projetos arquitetônicos 102 pois eram eles que poderiam saber das necessidades do espaço, além de incluída ela deveria se sentir uma realmente como uma comunidade. Os arquitetos e construtores agiram mais como técnicos e assessores.

Existiam os padrões ${ }^{103}$, importante para compreender os problemas e guiar o processo de projetar, trata-se de um conceito também democrático que auxilia a comunicação de ideias entre os profissionais e os usuários. Esses parâmetros são subdivididos em eixos específicos dentro das escalas projetuais: áreas comuns, edifícios, bairros, cidades e regiões ${ }^{104}$ (Alexander et al. 1977; 1979).

Os padrões de Alexander englobam elementos de outras teorias urbanas como as da Cidade Jardins (apresentada no capítulo 2) que inspiraram as áreas externas de encontros e as ruas voltadas para os pedestres que, em Oregon, recebeu o nome de Promenade.

${ }^{102}$ Alexander era a favor e utilizou de participações comunitárias para a concepção de seu projeto em Oregon.

103 De seu livro de 1977, Alexander et al., é interessante ressaltar o padrão quarenta e três, a origem do mapeamento de um espaço universitário, que abrange os espaços físicos e sociais estimuladores da liberdade e individualidade de seus usuários. Neste exemplo, a Universidade de Oregon foi concebida através de pequenas edificações distribuídas por vias de pedestres.
A Promenade é a via de circulação central, abrangente e que dá acesso aos principais edifícios (Alexander et al., 1977).

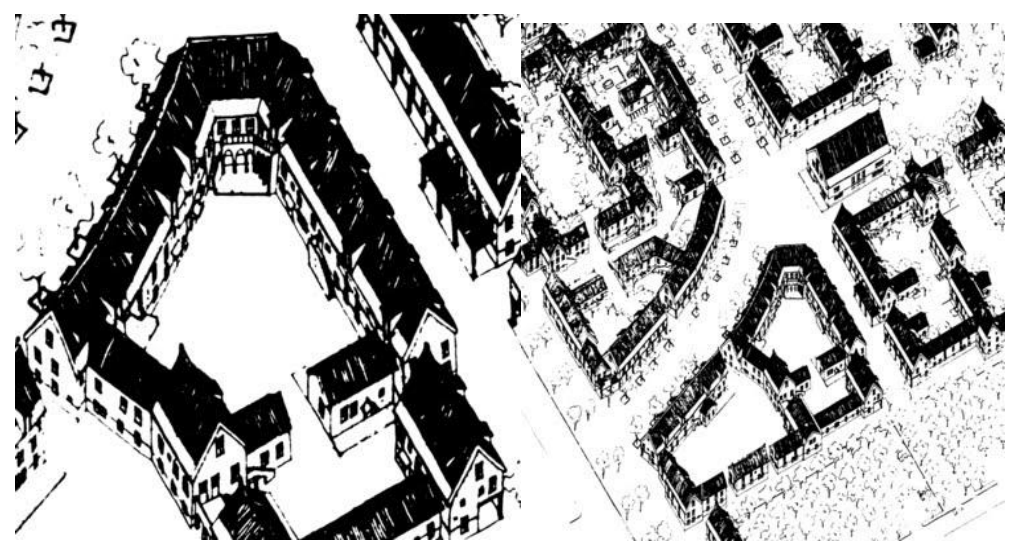

Figura 43- Projeto das unidades estudantis projetado por Alexander para a Universidade de Oregon, esse projeto visava a aumentar o senso de comunidade do campus, sem data.

(Fonte: http://www.rainmagazine.com/archive/1994/alexander-visitsthe-oregon-experiment, acessado dia 17 de julho de 2016, as 13:08 horas).

O projeto para o campus, então, mesclou edifícios administrativos com os acadêmicos e áreas de estar e convívio ${ }^{105}$, foi

${ }^{104}$ Foram desenvolvidos duzentos e cinquenta e três padrões por Alexander e sua equipe, parâmetros esses que descrevem um problema e apresentam núcleos de soluções passíveis de serem resolvidas de maneira democrática e comunitária. É possível utilizar dessas soluções "um milhão de vezes, sem fazê-lo da mesma forma duas vezes" (Alexander et al., 1977).

105 Alexander utilizou-se do "Princípio da Crescimento Orgânico", ou seja, a flexibilidade do campus e suas atividades se expandirem harmonicamente com o projeto inicial conforme surgem as necessidades futuras da universidade, uma 
uma revisão e mudança paradigmática da arquitetura e do urbanismo modernos, uma nova visão para planejadores de territórios universitários, uma crítica ao zoneamento e à cidade projetada para o automóvel ${ }^{106}$ (Alexander et al., 1979).

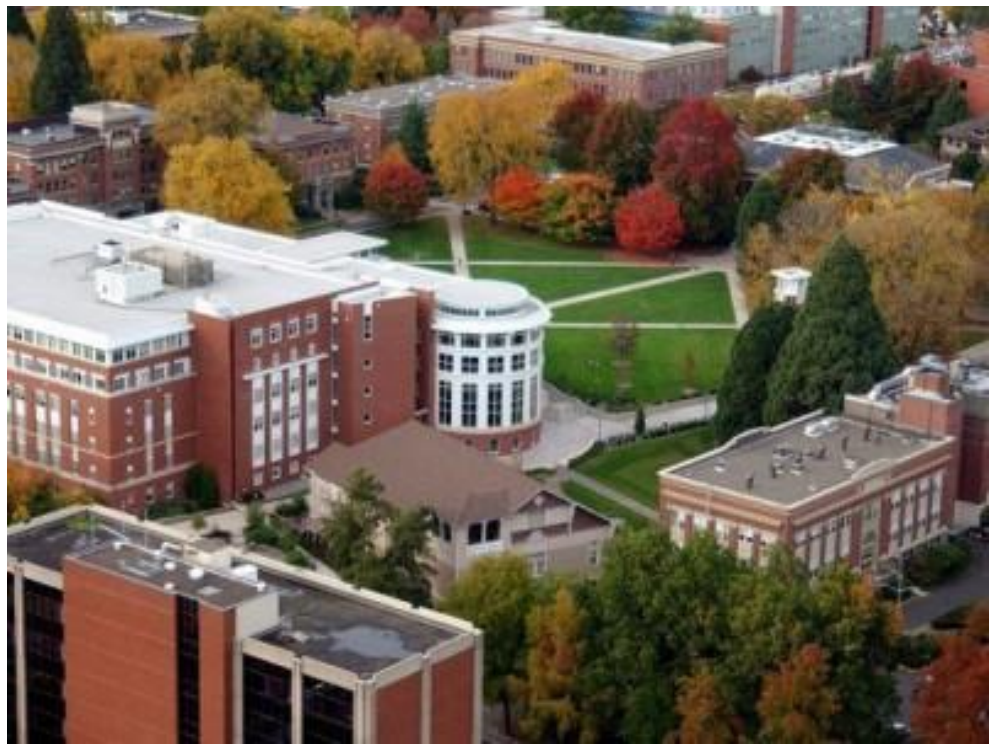

Figura 44- Vista do campus de Oregon onde é possível observar, em especial, o Promenade, sem data.

(Fonte: http://gradeup.com.br/universidade/oregon-state-university-2/, acessado dia 17 de julho de 2016, as 13:13 horas).

possibilidade menos fechada e rígida do que ocorrem nos planos de expansão; essa expansão espontânea respeita as características e preceitos vernaculares de um espaço urbano relacionado aos campus.
As principais edificações e prédios administrativos ficavam localizados ao longo do cruzamento viário principal, os edifícios de aulas e laboratórios estavam dispostos de forma irregular neste cruzamento para depois serem espalhados de forma dispersa até se misturarem com a cidade, permitindo sua integração com a comunidade.

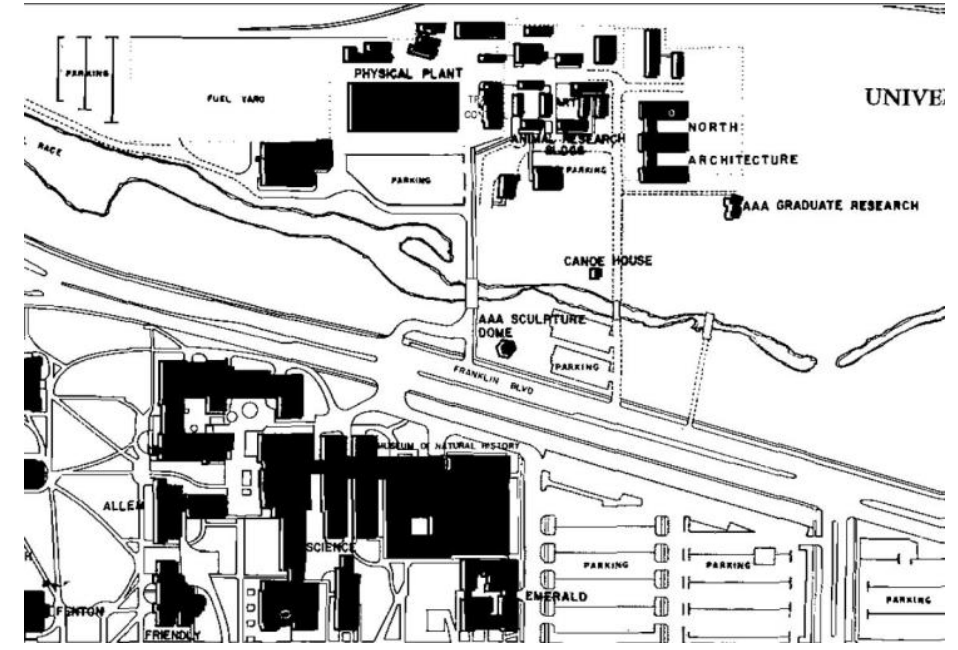

Figura 45- Mapa do campus da Universidade de Oregon antes do planejamento de C. Alexander, 1969. (Fonte:

https://library.uoregon.edu/sites/default/files/node3492/UOCAT 1969.JPG, acessado dia 17 de julho de 2016, as 19:29 horas).

${ }^{106}$ A crítica para esse projeto era também a grande escala das obras que deixavam de levar em conta o entorno e a possibilidade de crescimento ao longo dos anos No limite essa perspectiva a crítica ao Moderno e à Modernidade empreendidos por pensadores de diferentes campos do conhecimento. 


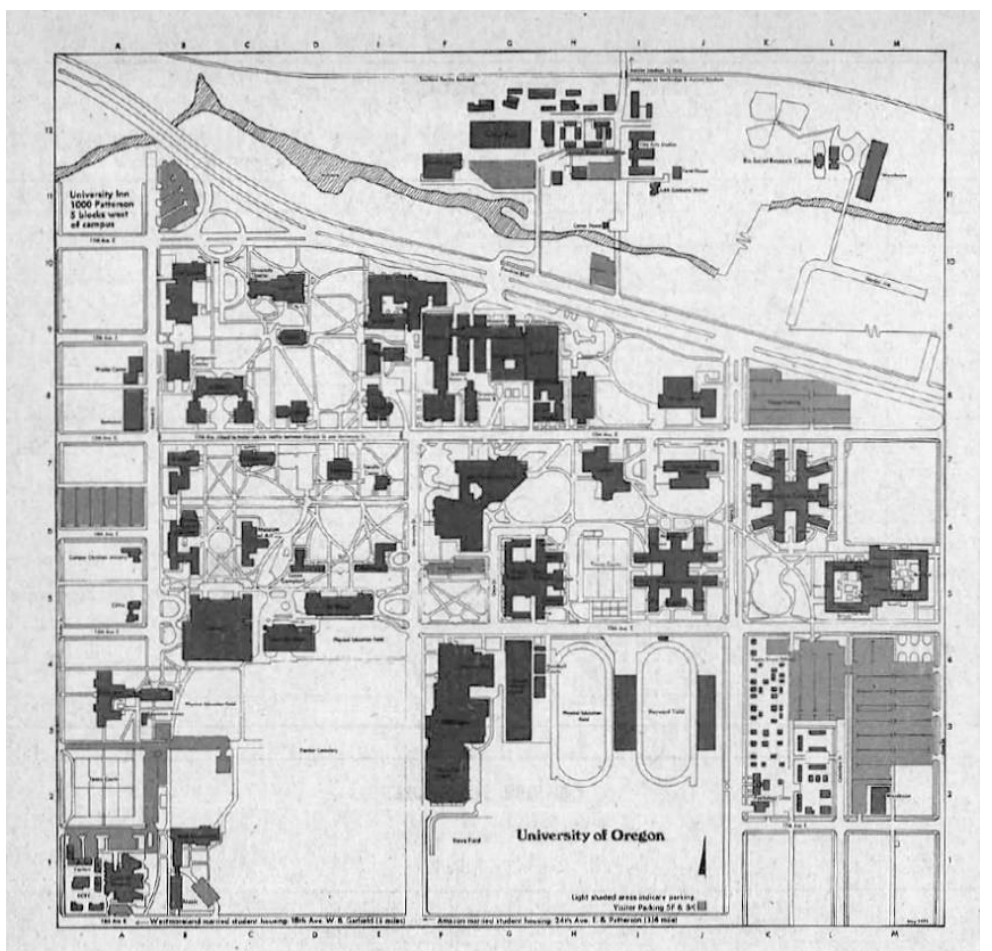

Figura 46- Mapa do campus da Universidade de Oregon após o planejamento de C. Alexander, 1975.

$$
\text { (Fonte: }
$$

https://library.uoregon.edu/sites/default/files/node3492/campusmap.jpg,

$$
\text { acessado dia } 17 \text { de julho de 2016, as 19:31 horas). }
$$

Com esse ideal para a criação de espaços mais humanos as universidades começaram a repensar seus espaços utilizando menos da monumentalidade e mais de praticidade.

\subsection{Cidades Universitárias brasileiras}

O termo Cidade Universitária é pouco usual. Segundo Pinto e Buffa (2009), o termo foi utilizado em dois acontecimentos: por Gustavo Capanema, com a fundação da Universidade do Brasil, e em 1930 com a criação da Universidade de São Paulo, USP.

O desenvolvimento dos campi no país é bastante análogo, apenas com pequenas variações; é o espaço de ensino que conta, em sua grande maioria, com a administração, refeitórios, biblioteca e bancos, somente.

"O Estado desapropria ou, às vezes, ganha uma determinada área, geralmente distante da cidade, por ser menos onerosa, solicita a contribuição de alguns profissionais para a elaboração de um plano e de um projeto arquitetônico (...). As verbas terminam e a obra de construção do câmpus para. Nova administração, (...) novas verbas e uma nova equipe, dessa vez, geralmente composta de docentes altamente titulados: um novo plano é realizado, novas metas são definidas. Realiza-se o que a verba permite. Fim da verba, fim da equipe, fim do plano e, quase sempre, fim das obras" (Pinto e Buffa, 2009, p. 47).

A Universidade do Rio de Janeiro, criada em 1920, foi a única, desde então, que se manteve com o nome de 'universidade' e a primeira a ser criada pelo Governo Federal. As universidades 
brasileiras, como já citado, nasceram a partir de escolas preexistentes. A USP, por exemplo, é criada a partir da organização de escolas que foram unidas por uma reitoria criada no período.

Segundo Pinto e Buffa (2009), até o Estado Novo (1937-1945) as universidades eram guiadas pelos modelos europeus, passando, depois, a seguir os modelos de campi estadunidenses.

\subsubsection{Universidade do Brasil: a Universidade Federal do} Rio de Janeiro e as propostas de Le Corbusier

Francisco Campos, em 1931, autorizou a Universidade do Rio de Janeiro a incorporar em sua estrutura inicial faculdades como Escola de Minas, Faculdade de Farmácia e também a Escola Nacional de Belas-Artes. Apesar da reestruturação, a Universidade do Rio de Janeiro continuou por alguns anos desprovida de uma Faculdade de Educação, Ciências e Letras, fato que a descaracterizaria como universidade na acepção do termo. Esta deficiência influenciava diretamente na falta de profissionais qualificados para o ensino normal e secundário.

No ano de 1934, Gustavo Capanema tornou-se ministro da educação e saúde. Neste cargo, Capanema foi responsável por organizar o texto que estabelece as bases para criação da Universidade do Brasil ${ }^{107}$. Criada a partir da Universidade do Rio de Janeiro, a Universidade do Brasil era responsável por formar mão de obra qualificada que viria a ocupar cargos de magistério e altos cargos públicos, enfim, era responsável pela preparação de profissionais que exerceriam profissões que dependiam do ensino superior. A estrutura da Universidade do Brasil compreendia os prédios já existentes da antiga Universidade do Rio de Janeiro e novos prédios administrativos (Caram, 2014). Capanema compreendia que o ensino deveria ser absorvido não por memorizações, mas sim através de pesquisas e práticas, para isso a universidade deveria contar com clínicas, laboratórios, bibliotecas e museus; esses conjuntos foram chamados por ele de 'Cidade Universitária' (Pinto e Buffa, 2009).

\footnotetext{
${ }^{107}$ Em 1937 a universidade passa a ser chamada de Universidade do Brasil e tinha a proposta de ser modelo para as outras que viriam a ser criadas no país.
} 
Nesse momento os edifícios eram isolados, como os modelos europeus, "criando quadras temáticas, ou parte de bairros caracterizados como núcleos universitários" (Mahler, 2015, p. 117).

Em 1935, Capanema revisa o Plano Agache 108 e pede por novos estudos sobre a viabilidade de realmente inserir a Cidade Universitária na Praia Vermelha; foram apresentados dois projetos: "um pelo arquiteto Evaristo Sá, outro proposto pelo engenheiro José Otacílio Saboya Ribeiro" (Alice, 2004, p. 26 apud Mahler, 2015, p. 117). Foi criada então uma comissão técnica para realizar estudos e projetos para a universidade.

A equipe, composta por Lucio Costa, Paulo Fragoso, Afonso Eduardo Reidy, Angelo Bruhns e Firmino Saldanha.

\begin{abstract}
"Contrariando as hipóteses de localização então em discussão - Praia Vermelha e Quinta da Boa Vista -, a equipe de Lucio Costa apresentou, em junho de 1936, uma terceira e inusitada proposta para um campus em palafita sobre a lagoa Rodrigo de Freitas prontamente rechaçada e sobre a qual se desconhece qualquer registro gráfico. Essa surpreendente proposta (...) foi vetada por motivos técnicos" (Mahler, 2015, p. 118).
\end{abstract}

108 "O plano Cidade de Rio de Janeiro: extensão, remodelação e embelezamento, desenvolvido pelo urbanista Alfred Agache entre 1929 e 1930, não só consagrava
O projeto escolhido foi na Quinta da Boa Vista e contou com três propostas projetuais dos seguintes arquitetos: Le Corbusier, em 1936, a revisão de Lucio Costa e equipe, também no ano de 1936, e o de Marcelo Piacentini e Vittorio Morpurgo, nos anos de 1937- 1938 (Mahler, 2015).

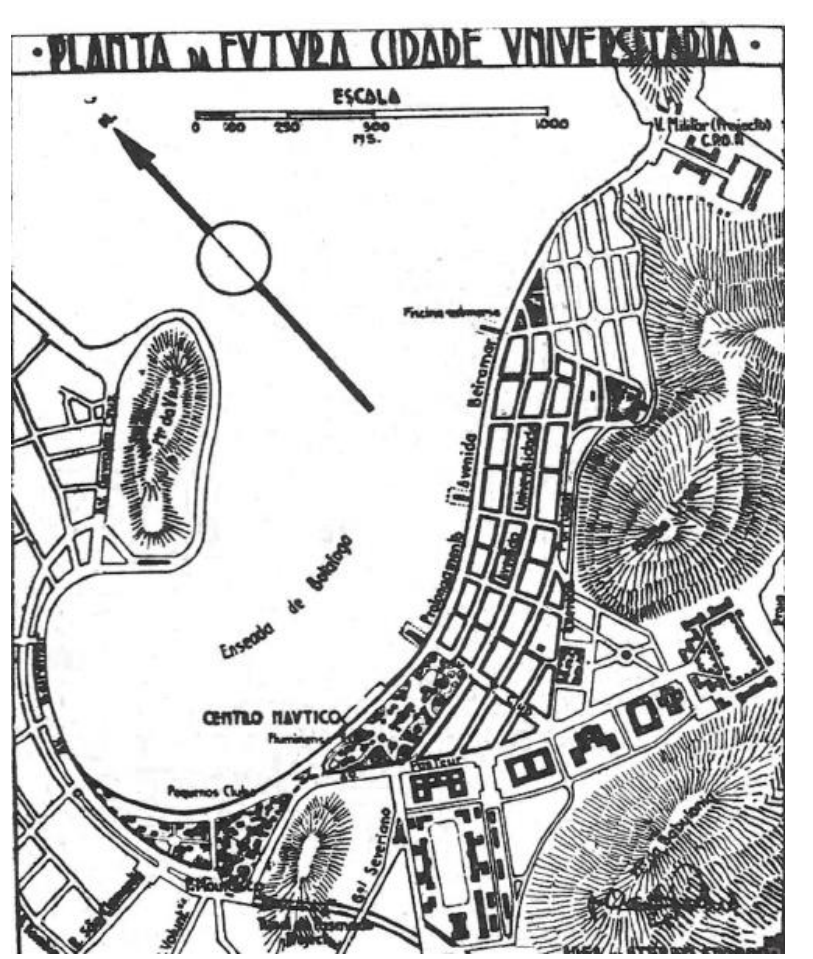

Figura 47- Planta da futura Cidade Universitária, Praia Vermelha, 1935. (Fonte: Mahler, 2015, p. 115).

a Praia Vermelha como bairro acadêmico como previa a construção integral de uma cidade universitária" (Mahler, 2015, p. 117). 
Foi Lucio Costa quem convidou Le Corbusier para projetar a Cidade Universitária na Quinta da Boa Vista.

\begin{abstract}
"O plano urbanístico apresentado, juntamente com uma perspectiva geral e um relatório com indicações do zoneamento compõe os documentos desta etapa. Sua ideia era fazer deste projeto um fragmento de sua cidade ideal. A composição propôs edificações isoladas com volumetrias em destaque, articulando-se por espaços de circulações para pedestres e veículos, com valorização da paisagem e adjacências" (Mahler, 2015, p. 120).
\end{abstract}

A implantação proposta partia de eixos ortogonais nos quais estariam localizados importantes edifícios. O centro do campus seguia uma grelha geométrica que unia as vias e as ligava até o estacionamento, esse centro geométrico corresponde a ausência de espaços de convívio social e "espaços abertos entre os edifícios, inespecíficos" e sem diferenciação entre eles (Mahler, 2015, p. 120).
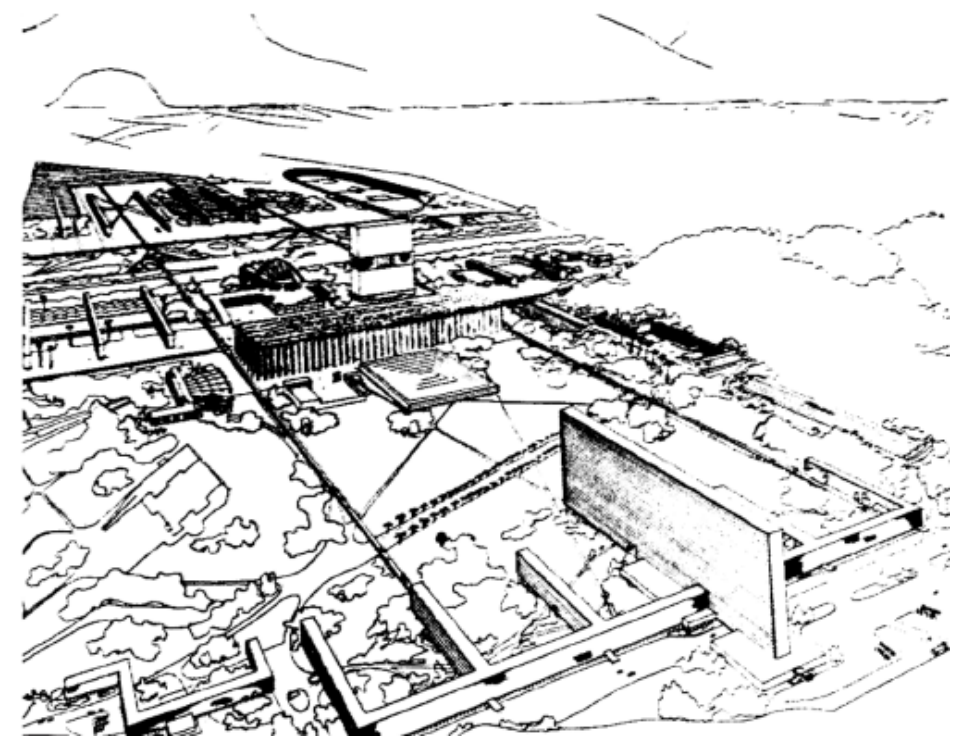

Figura 48- Projeto de Le Corbusier para a Cidade Universitária da Universidade do Brasil, 1936. (Fonte: Mahler, 2015, p. 119).

No projeto de Piacentini e Mopurgo, com influências da Universidade de Roma (que no período era imersa da cultura arquitetônica e urbana fascistas), os jardins da Quinta da Boa Vista são preservados e são criados eixos que permitiram a renovação do local. A avenida central divide-se em eixos menores e paralelos que criam um espaço no centro (Mahler, 2015). 
Nenhuma das ideias foi utilizada, mas, apesar disso, a ideia de campus foi disseminada. Os projetos apresentados compuseram debates que discutiram o planejamento da Universidade do Rio de Janeiro e da Universidade de São Paulo.

Durante o Estado Novo, o projeto para a Cidade Universitária da Universidade do Brasil não recebeu tanta atenção e, consequentemente, financiamento, sendo "retomado décadas mais tarde" (Pinto e Buffa, 2009, p. 60). No fim da era Vargas, o país contava com cinco universidades: a Universidade do Brasil, a Universidade de Porto Alegre, a Universidade de São Paulo, a Universidade do Distrito Federal e as Faculdades Católicas (Caram, 2014).

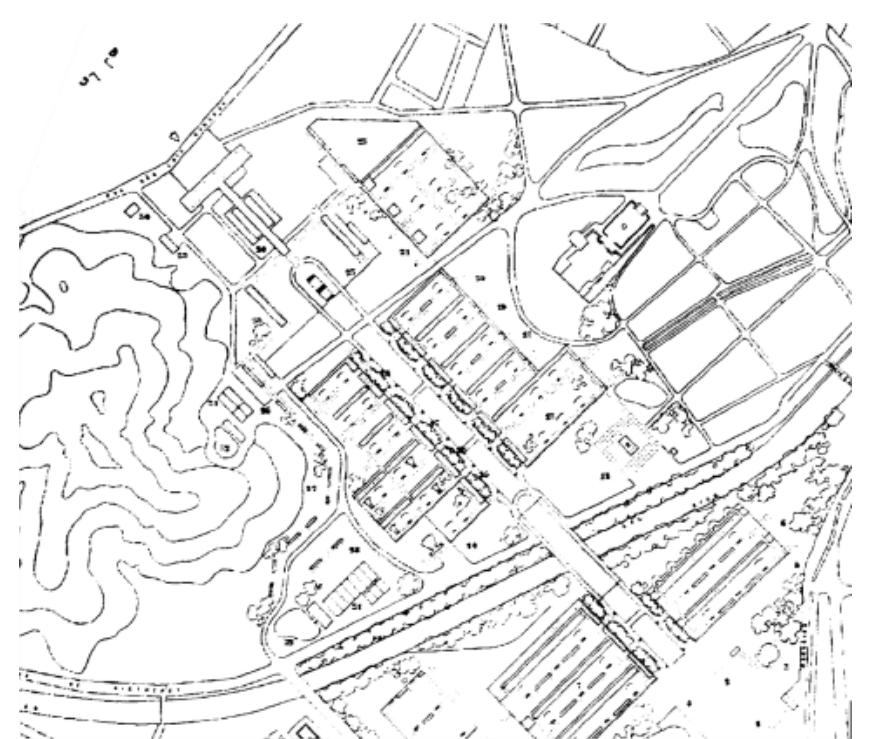

Figura 49- Projeto de Lucio Costa e equipe para a Cidade Universitária da Universidade do Brasil, 1936.

(Fonte: Mahler, 2015, p. 119).

A criação da cidade universidade da Universidade do Brasil "marcou o início do pensamento acerca de um território universitário no Brasil seguindo em parte o conceito americano" (Mahler, 2015, p. 117).

A Cidade Universitária foi transferida em 1945 para uma ilha artificial na área norte da cidade, a Ilha do Fundão, onde, em 1954 já havia se consolidado como um campus universitário do que viria a ser, nos próximos anos, a Universidade Federal do Rio de Janeiro. Os prédios que foram utilizados na Praia Vermelha também continuaram 
funcionando como extensão das atividades da Ilha do Fundão (Pinto e Buffa, 2009).

O projeto escolhido foi do arquiteto que havia trabalhado nos projetos de Le Corbusier e Lucio Costa: Jorge M. Machado e equipe. O projeto partiu de "eixos ortogonais básicos que percorreriam toda a área da ilha em dois sentidos", os edifícios, que ficavam localizados nesses eixos, possuíam ligações entre si através de vias menores (Pinto e Buffa, 2015, p. 61).
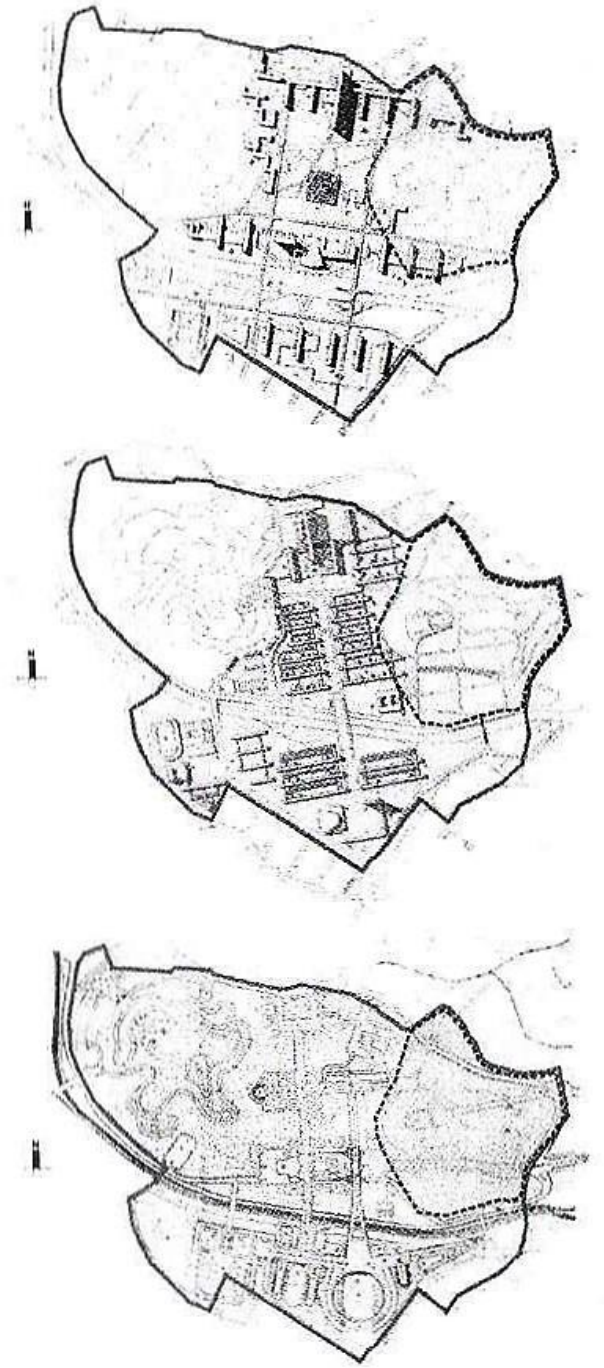

Figura 50- Comparação entre os projetos de Piacentini, Le Corbusier e Lucio Costa e equipe, respectivamente.

(Fonte: Pinto e Buffa, 2009, p. 60). 
Atualmente a universidade participa da malha urbana, assim como outras universidades brasileiras que inicialmente foram criadas distantes das cidades. Se a proposta da Universidade Federal do Rio de Janeiro, UFRJ, era ser um modelo de Cidade Universitária, isso não ocorreu especialmente por falta de infraestrutura que promovesse ao espaço sua projetada autossuficiência. Apesar disso a proposta para o campus da UFRJ materializa a modernidade em nosso território, como a racionalização do espaço, os eixos e até mesmo as áreas verdes.

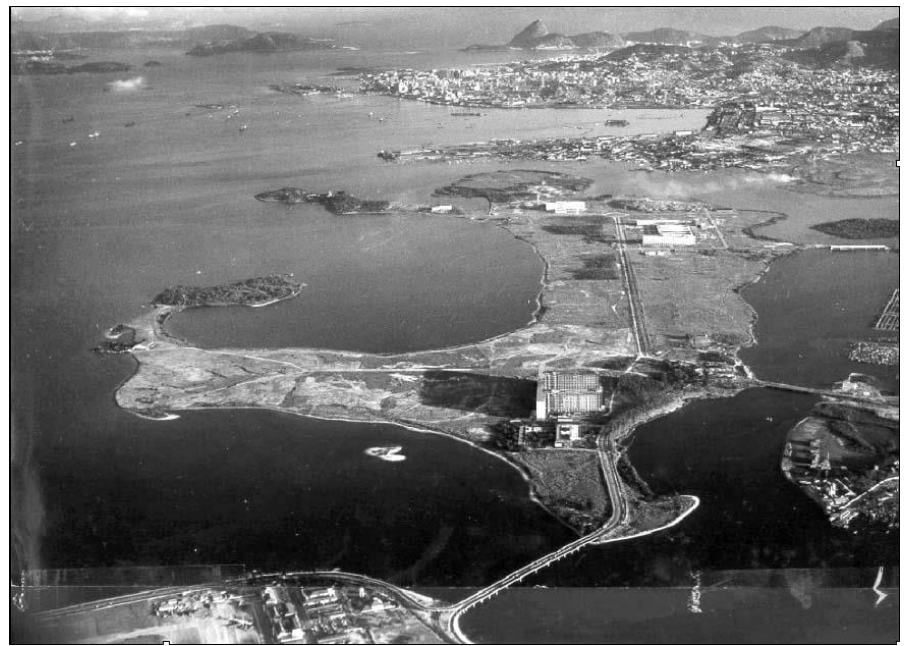

Figura 51- Vista e planta da Universidade Federal do Rio de Janeiro, sem data. (Fonte:

http://www2.faced.ufu.br/colubhe06/anais/arquivos/519GelsonAlmeidaPinto_Est erBuffa.pdf, acessado dia 14 de julho de 2016, as 16:10 horas).
4.3.2. A Universidade de São Paulo e a Cidade Universitária 'Armando de Salles Oliveira'

No processo de fundação das universidades no início do século $X X$, a USP se enquadrava no projeto político da oligarquia paulista que pretendia construir na capital uma instituição de ensino de nível superior, moderna e dedicada à ciência e à pesquisa. A condição econômica favorável do Estado de São Paulo contribuiu diretamente para a implantação da universidade. Outro importante fator foi a existência de boas escolas primárias que criaram a demanda por instituições de ensino secundário e superior.

Como já apresentado anteriormente, na cidade de São Paulo foi inaugurada, em 1873 a Sociedade Propagadora de Instrução Popular cujo objetivo era especializar a mão de obra industrial, essa instituição democratizou o ensino. Em 1882, a Sociedade passa a ser chamada de Liceu de Artes e Ofícios de São Paulo e inicia o ensino profissional voltado às oficinas, comércio e lavoura. Em seu currículo, entre disciplinas técnicas, exatas e artísticas.

Com a proclamação da República, o Liceu passa por crises financeiras. No ano de 1895 o engenheiro-arquiteto Francisco de 
Paula Ramos de Azevedo torna-se diretor e promove grandes reformas no ensino da instituição. A partir do Liceu surge o que resultou na Escola Politécnica de São Paulo (Costa, 2008).

Com o aumento da industrialização, no final do século XIX, e o consequente aumento populacional causado por migração e imigração, houve o crescimento das cidades do estado de São Paulo e a necessidade de ampliação e melhoramento da infraestrutura.

A criação da Escola Politécnica de São Paulo foi a resposta do Estado e da capital de se adaptarem às mudanças causadas pela Segunda Revolução Industrial. A isso se associa a necessidade de realização de melhoramentos urbanos para o desenvolvimento das cidades. Esse contexto criou uma demanda por novas posições em relação ao ensino profissional, principalmente na área de Engenharia Civil e Arquitetura (Caram, 2014).

Com o aumento da industrialização, no fim do século XIX, e o consequente aumento populacional causado por migração e imigração, houve o crescimento das cidades do Estado de São Paulo e a necessidade de ampliação e melhoramento da infraestrutura. Assim é criado o primeiro regulamento da Escola Politécnica, em
1894, que visava o ensino técnico voltado para a agricultura, a indústria e a construção. Foram então criados os cursos de engenheiro civil, industrial e agrícola, além de um curso de mecânica para quem não tivesse formação colegial (Costa, 2008).

A década de 1930 foi importante para a Escola Politécnica que passa a ser incluída nas escolas que iriam compor a Universidade de São Paulo, USP, em $1934^{109}$ (Domschke, 2007).

O modelo da USP foi inspirado no de campus estadunidense.

"A centralização dos elementos componentes da nossa instituição, em um ou mais campus, constitui, sem dúvida, o fator máximo determinante do progresso e desenvolvimento que o poder atual e potencial do nosso grande centro de estudos exige para a formação de um ambiente comum, homogêneo e de maior produção. Além do mais, muitas das escolas (...) mal instaladas em prédios adaptados e inconvenientes ou mal localizados em pleno centro urbano (...) terão, com a concentração em um campus-parque, amplo espaço de trabalho, em edifícios especificamente construídos para cada uso, em local arejado e agradável, tanto para o estudo como para o convívio social e esportivo. (...) depois de um longo período de propaganda e de projetos, surge o grande campus do Butantã, onde se concentrarão, em vasto e arborizado parque, todas as outras unidades universitárias (...). Constituirão impressionante centro universitário para a maior glória de São Paulo e do Brasil” (Campos, 2004, p. 152-153).

${ }^{109}$ A USP foi criada pelo Decreto n. 6.283 de 25 de janeiro de 1934 (Caram, 2014). 
A construção da Cidade Universitária deu-se em 1935 porém, com o golpe de Estado em 1937, os projetos para a construção do espaço universitário da USP foram deixados de lado até 1940 quando

o Escritório de Obras especificou o plano urbanístico para a área (Mahler, 2015).

Em 1942, o Instituto de Pesquisas Tecnológicas foi transferido para a Cidade Universitária sendo oficialmente o primeiro edifício construído no campus, algumas melhorias como a retificação do Ribeirão Jaguaré e a construção de uma estação de fornecimento de energia elétrica foram realizadas (Mahler, 2015).

As primeiras propostas para o campus da USP era "concentrar os diversos edifícios em um campus-parque, que seria um 'amplo espaço de trabalho, em edifícios especificamente construídos para cada caso, em local arejado e agradável, tanto para o estudo como para o convívio social e esportivo'”. Era proposto então uma centralização dos edifícios e atividades universitárias "dispostos em parques amplos e bem arborizados (...) convidativo a uma permanência mais prolongada, (...) elemento de valor inestimável para a formação do espírito universitário" (Campos, 2004, p. 152-
160). Isso corrobora com a afirmação do modelo de Campus explicitado.

A construção da Cidade Universitária da USP passou por problemas de repasse de verba, mas, ainda assim, ocorreu no ano de 1945 um concurso para a elaboração de todo o projeto do campus; o vencedor foi o engenheiro-arquiteto Hipólito G. Pujol Júnior e equipe, com o projeto denominado 'Accuratus'.

Em 1948 é criada uma nova comissão composta por Ernesto de Souza Campos, Luis Inácio de Anhaia Mello, Adriano Marchini, José M. da Silva Neves e Christiano S. das Neves.

As obras para a Cidade Universitária foram um laboratório para a arquitetura moderna e uma nova linguagem estética (Caram, 2014).

Já no ano de 1951 são abertas novas ruas e avenidas e criadas novas praças, novos prédios foram construídos para "assegurar a ocupação da gleba" (Mahler, 2015, p.135).

“A região da cidade universitária é configurada por uma grande área plana, ao lado do Rio Pinheiros e, do lado oposto do terreno, apresenta suaves elevações. A região próxima ao rio foi drenada, aterradas em algumas partes e a princípio reservada para a formação de um lago, proposta posteriormente reavaliada, tornando-se o lago uma raia olímpica. As ruas nessa região plana foram definidas a partir do eixo do rio, 
paralelas e de largura generosa. Travessas perpendiculares formavam uma grade ampla que definia regiões para a instalação de edifícios. As áreas destinadas aos esportes foram, por suas necessidades e características, implantadas nessa região plana e próxima ao rio. Entre essa área plana e o início das pequenas colinas foi proposta a entrada principal da Universidade: uma via que conduzia diretamente ao cuore da cidade universitária. Um centro cívico foi projetado por Rino Levi e Cerqueira Cesar. O conjunto, que era formado pela torre universitária, reitoria, teatro universitário e biblioteca, ficaria disposto ao redor de uma praça triangular e contaria com um paisagismo proposto por Burle Marx. (...) Na região das colinas, o arruamento seguia um desenho mais orgânico segundo a topografia criando, ao mesmo tempo, regiões, setores para a instalação de novas unidades acadêmicas" (Pinto e Buffa, 2009, p. 78).

Segundo Pinto e Buffa (2009, p. 80), a USP até o ano de 1955 contou com a proposta de dez projetos distintos que não foram aceitos. Após essa data o arquiteto Hélio Duarte "apresentou uma proposta de planejamento da cidade (...) que tentava dar continuidade (...)para o plano da universidade". A proposta previa várias mudanças e adaptações do projeto aprovado anteriormente inspiradas nos Congressos Internacionais de Arquitetura Moderna, de 1951, inclusive a construção de projetos de Oswaldo Bratke e Rino Levi, além de uma maior integração à cidade. Nesta proposta, o centro do campus, que seria o centro de edifícios isolados, teria a possibilidade de crescimento.

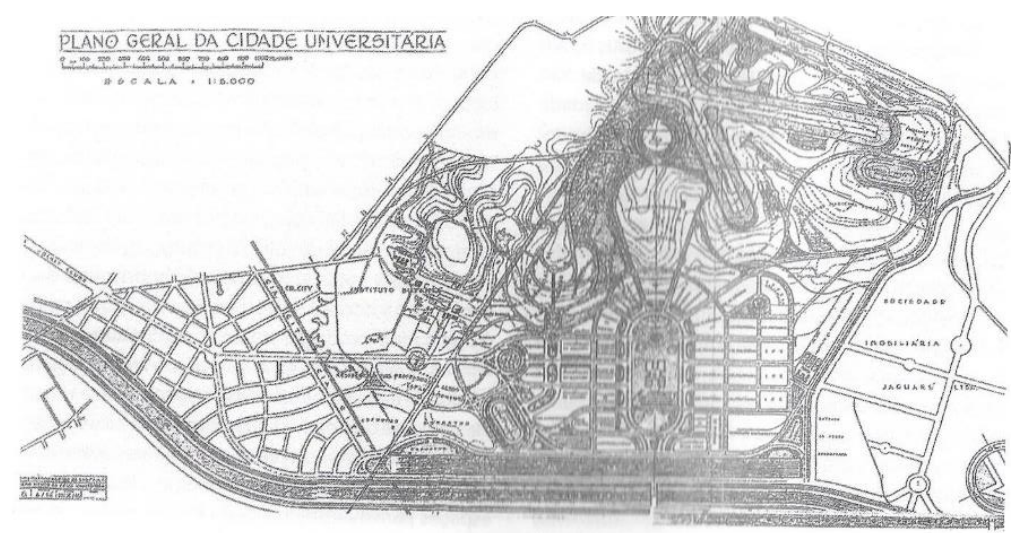

Figura 52- Projeto para a Cidade Universitária, 1945. (Fonte: Pinto e Buffa, 2009, p. 84).

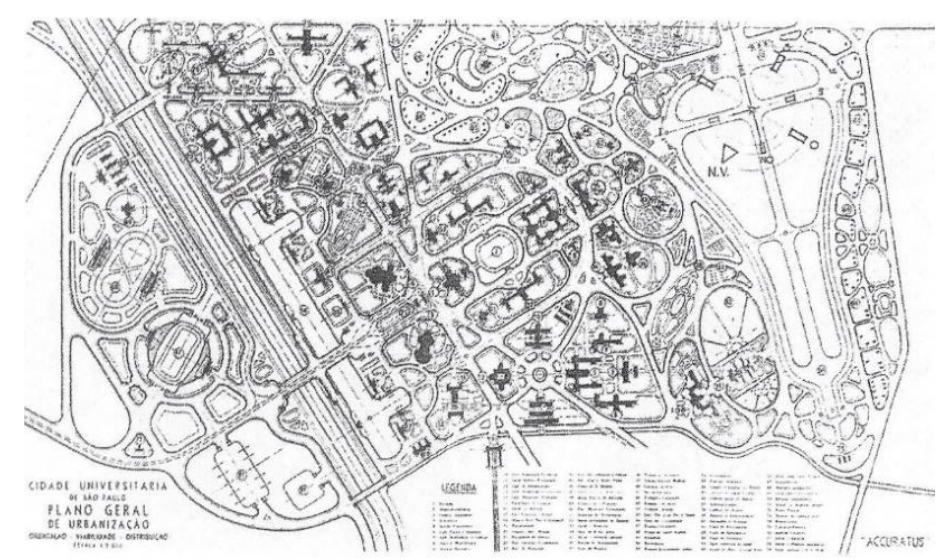

Figura 53- Projeto vencedor para a Cidade Universitária, sem data. (Fonte: Pinto e Buffa, 2009, p. 86) 


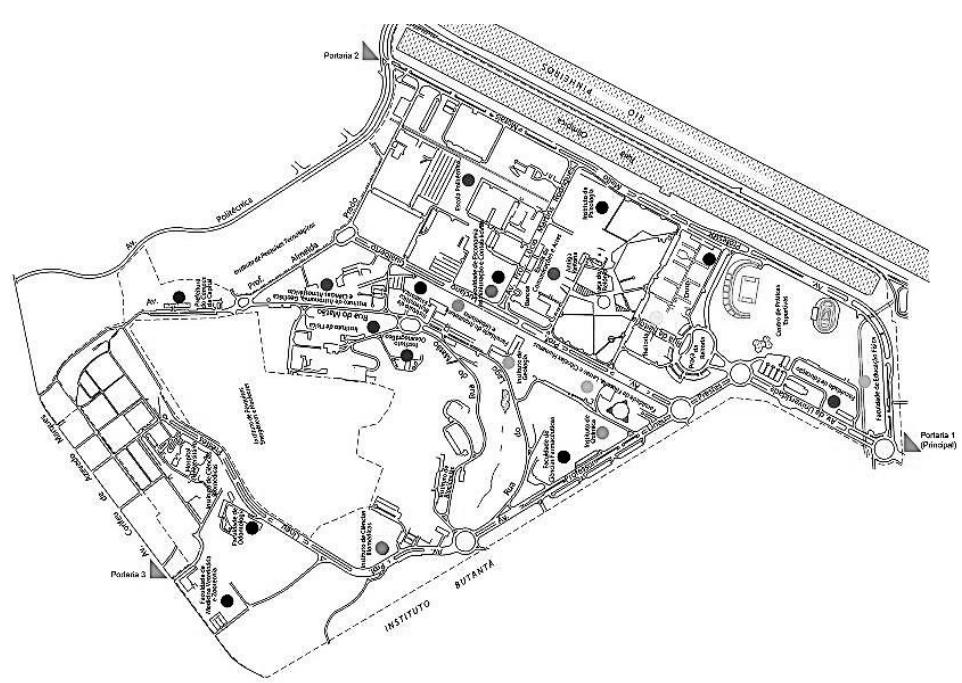

Figura 54- Planta da atual Cidade Universitária, sem data.

(Fonte: http://www.nahuhostel.com.br/pt/mapa_usp_imprimir.html (acessado dia 19 de junho de 2016, as 22:16 horas).

O processo de construção da Cidade Universitária no período de constituição do FUNDUSP ${ }^{110}$, Fundo para a Construção da Cidade Universitária, contou com projetos de professores e importantes nomes da arquitetura e da engenharia, como Villanova Artigas e Paulo Mendes da Rocha. Os edifícios projetados seriam implantados de uma maneira a criar uma via que seguiria até o centro cívico, o interessante

110 O FUNDUSP foi criado em 1960 e contou com Paulo Camargo e Almeida como seu diretor executivo. Em 1970 o FUNDUSP publicou manuais que padronizavam os elementos construtivos e suas dimensões para edifícios de ensino. O FUNDUSP, é que a proposta também previa que o saguão de cada edifício possibilitasse a "circulação livre entre eles", era uma proposta de integrar toda a universidade. Essa proposta foi interrompida pelo golpe de 1964 e seu governo ditatorial (Pinto e Buffa, 2009, p. 82).

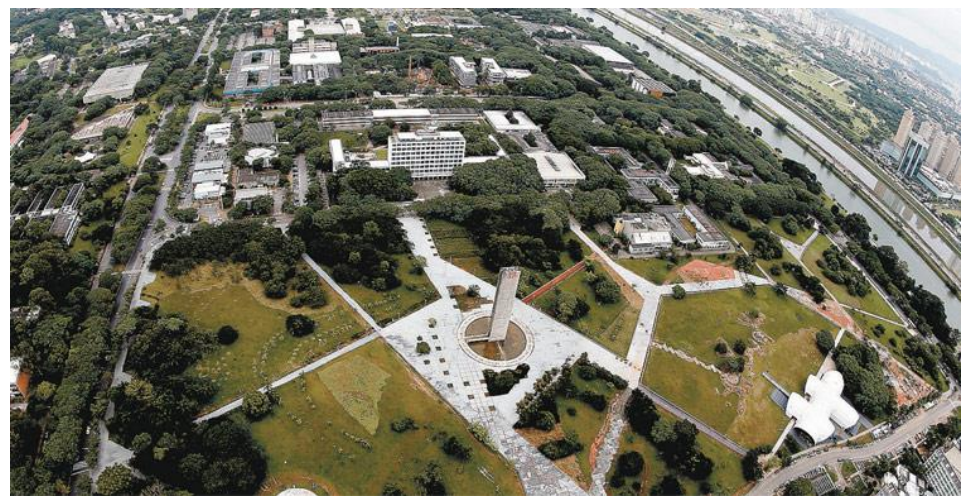

Figura 55- Vista aérea da atual Cidade Universitária, sem data. (Fonte: http://f.i.uol.com.br/folha/publicidade/images/14279780.jpeg, acessado dia 21 de julho de 2016, as 22:14 horas).

Apenas na década de 1970 que alguns poucos projetos concebidos antes do golpe foram construídos, como a torre de Rino Levi e a área desportiva.

após ser remodelado em 2002, tornou-se o COESF, Coordenadoria do Espaço Físico (Pinto e Buffa, 2009). 
4.3.3. A Universidade de Brasília: um novo modelo que une o espaço universitário e o modelo de ensino

O golpe militar brasileiro ocorrido no ano de 1964 e a Reforma Universitária de 1968 contribuíram para a modificação do modelo universitário vigente até então.

A Reforma Universitária foi importante para que fossem considerados novos modelos para o espaço universitário. Segundo Pinto e Buffa (2009, p. 107), foi depois da Segunda Guerra que o país começou a compreender a instituição de ensino superior "como uma estratégia para produzir o conhecimento necessário ao desenvolvimento científico e tecnológico", além da pesquisa como uma das atividades mais importantes das universidades.

Foi nesse momento, também, que importantes agências de fomento à pesquisa como o Conselho Nacional de Desenvolvimento Científico e Tecnológico, CNPq, e a Coordenação de Aperfeiçoamento de Pessoal de Nível Superior, CAPES, fundadas em 1951, e a Fundação de Amparo à Pesquisa do Estado de São Paulo, FAPESP, fundada em 1962, foram criadas (Pinto e Buffa, 2009).
Essa nova mentalidade acerca do papel da universidade no país fomenta, em 1960, a criação da Universidade de Brasília, UnB. A UnB foi implantada, em 1962, por Darcy Ribeiro e Anísio Teixeira (Pinto e Buffa, 2009). A UnB é característica e inovadora não só por ter nascido de projetos e não de escolas que já existiam, mas pelo programa criado por Darcy Ribeiro, Anísio Teixeira e equipe que propôs a implantação do campus de acordo com o programa pedagógico da universidade.

A UnB nasce uma maneira inédita e peculiar: foi totalmente planejada, desde o seu início, seguindo propostas modernas, e não criada, como outras, a partir da justaposição de escolas já existentes. A UnB também não utilizou de sistemas de cátedras e do controle de departamentos, permitindo toda uma nova configuração espacial.

Assim, o espaço físico da nova universidade deveria traduzir suas propostas de maneira interdisciplinar e integrada. Seu projeto foi modificado diversas vezes durante o regime militar.

Originalmente, Lucio Costa havia proposto, no plano de Brasília, que a construção do campus fosse inserida no tecido urbano entre a asa norte e o lago Paranoá; pela proximidade do terreno com 
os prédios dos órgãos administrativos, a ideia foi barrada por motivos que o governo, no momento, julgou de segurança.

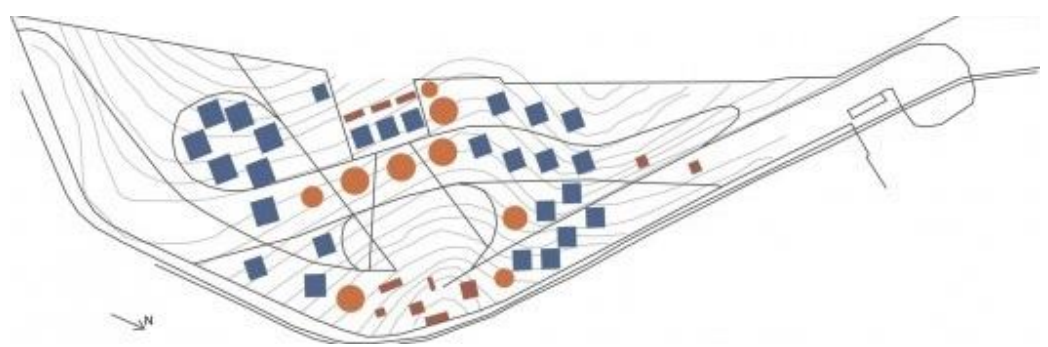

Figura 56- Implantação da UnB proposta por Lucio Costa, sem data. (Fonte:

http://www.vitruvius.com.br/revistas/read/arquitextos/16.184/5684, acessado dia 24 de julho de 2016, as 13:43 horas).

Para que fosse elaborado o Plano Orientador da Universidade de Brasília, foi criado o Conselho Diretor e, em 1962, Darcy Ribeiro foi nomeado reitor e presidente do Conselho. O Plano Orientador definiu que a universidade seria construída ao redor dos institutos, enquanto os "departamentos e faculdades seriam gradualmente implantados à medida que a instituição crescesse" (Pinto e Buffa, 2009, p. 121).

"O programa de construção dos prédios e instalações da Universidade de Brasília foi elaborado para ser executado em etapas progressivas e bem definidas. Esse programa de construção seguiria a própria estrutura de crescimento e implantação da universidade, uma vez que os institutos centrais ministrariam os cursos introdutórios, devendo ser instalados antes das faculdades, que só poderiam iniciar suas atividades dois anos após a inauguração dos cursos básicos" (Universidade de Brasília, 2007 apud Pinto e Buffa, 2009, p. 122).

Em abril de 1962 a universidade foi inaugurada ainda em meio a obras e com uma infraestrutura deficiente, crescendo gradualmente como planejado. Os programas arquitetônicos seguiam a proposta universitária.

O primeiro projeto para a universidade no terreno aprovado partiu de Lucio Costa, em 1962, como a continuação de seu projeto de Brasília. A proposta previa a presença de espaços vazios entre as construções que eram distantes entre si, o centro do campus contaria com a presença de uma praça cercada pelos Institutos Centrais (Pinto e Buffa, 2009).

Em 1963, Oscar Niemeyer e equipe tornam-se responsáveis e unem, em um só prédio, os três do Instituto Central de Ciências que estavam implantados separadamente por Costa, criando um edifício de 700 metros de extensão com flexibilidade de seus ambientes internos. Apesar das mudanças propostas para os edifícios, os espaços passaram a ser ocupados conforme necessidades imediatas, era uma maneira bastante desordenada, o que misturou serviços, laboratórios e salas de aulas. As tentativas de criar um espaço de 
ensino superior aberto à população também falharam, talvez porque a cidade fosse enfim mais atrativa, graças aos seus inúmeros espaços livres verdejados (Pinto e Buffa, 2009).

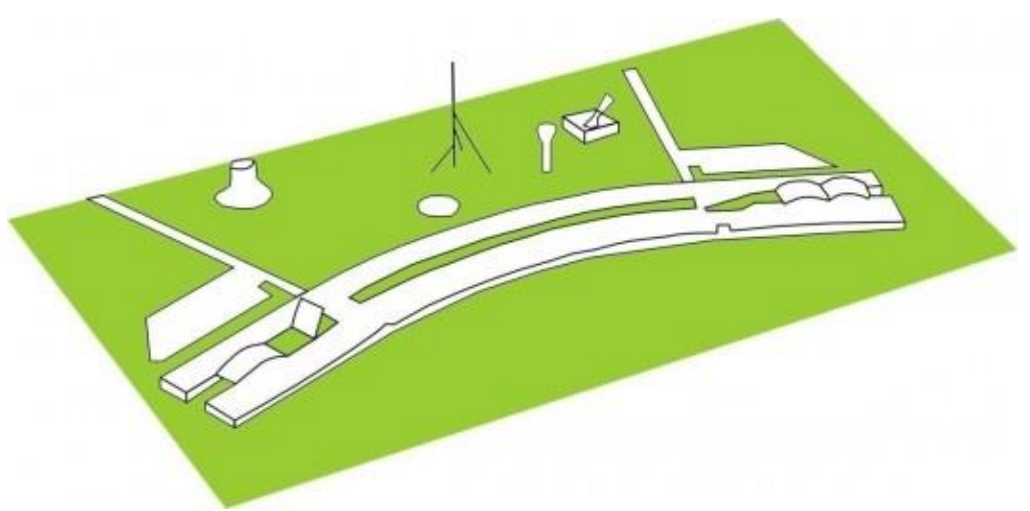

Figura 57- Projeto de Oscar Niemeyer e equipe para o Instituto Central de Ciências, sem data.

$$
\text { (Fonte: }
$$

http://www.vitruvius.com.br/revistas/read/arquitextos/16.184/5684, acessado dia 24 de julho de 2016, as 13:45 horas).

A implantação de Niemeyer era mais sintética, organizada e com propostas mais definidas, os edifícios estavam mais próximos uns dos outros e localizados em lotes definidos por atividades. (Pinto e Buffa, 2009).

111 Darcy Ribeiro em: http://www.vitruvius.com.br/revistas/read/arquitextos/16.184/5684, acessado dia 24 de julho de 2016, as 13:49 hrs.
"Gosto de dizer, para divertir os amigos, que foi por preguiça que Oscar projetou o Minhocão tal qual ele é: 780 metros de comprimento por 80 de largura, em três níveis. A verdade que há nisso é só que Lúcio Costa previa no plano urbanístico no campus da UnB oito áreas para os Institutos Centrais, cada uma delas contando com edifícios especializados para anfiteatros, salas de aula, laboratórios, departamentos, bibliotecas, etc. No total, somaria para mais de quarenta edificações que deveriam ser projetadas e construídas uma a uma. Oscar resumiu tudo isso num edifício só, composto por seis modalidades de construção, que permitiriam acomodar num conjunto qualquer programa de utilização. Ao fazê-lo porém, renovava a arquitetura das universidades, dando um passo decisivo, no sentido do que viriam a ser, depois, as universidades que ele desenhou pelo mundo"111.

Apesar de ainda inacabado, o 'Minhocão' é atualmente um "elemento organizador do campus (...), a partir do qual foram distribuídas as demais edificações" (Mahler, 2015, p. 261).

Entre 1969 e 1970, agora com outra equipe sem Niemeyer, foram propostas novas diretrizes para o campus: o alojamento dos alunos passa a ficar próxima a área de esportes e de uma nova área com restaurantes, lazer e estar. Apesar de existir uma equipe de 
planejamento para o campus, os edifícios estavam sendo construídos sem um projeto cuja qualidade não dialogava com as ideias originais, o planejamento da UnB foi frustrado pelas ações e controle militares. A partir de 1970 esse Centro de Planejamento passou a ser mais atuante.

Ainda segundo Pinto e Buffa (2009), a distância entre os edifícios acabou sendo um problema de circulação, os espaços de vivência não foram usados e a estratégia para solucionar essas questões passou a ser diminuir as distâncias e construindo nos vazios.

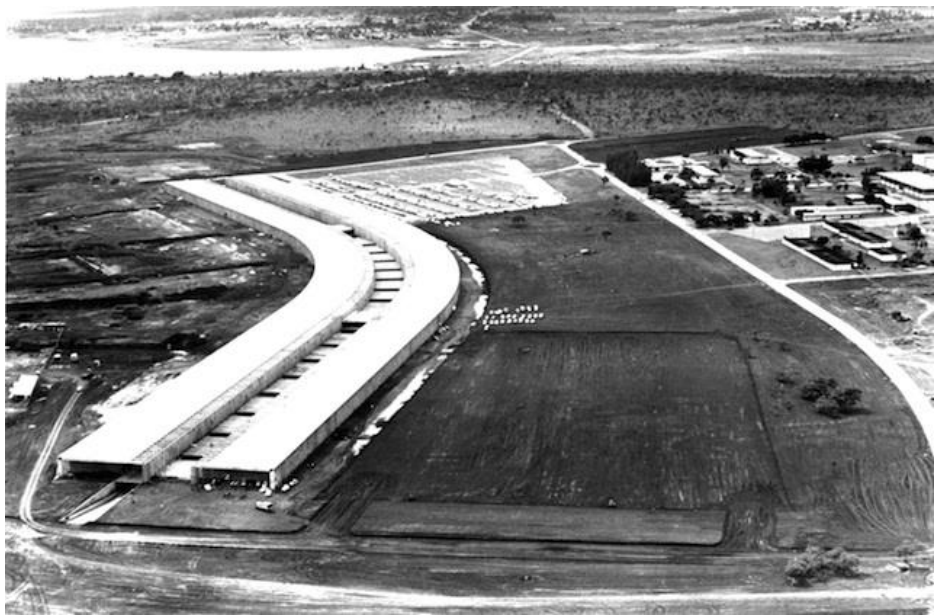

Figura 58- Construção do campus da UnB ainda sem os prédios da Biblioteca, Restaurante Universitário e Reitoria, sem data.

$$
\text { (Fonte: }
$$

http://campus.fac.unb.br/arquivo/campus12014/universidade/item/2213especial-arquitetura-na-universidade-de-bras\%C3\%ADlia, acessado dia 24 de julho de 2016, as 12:17 horas)

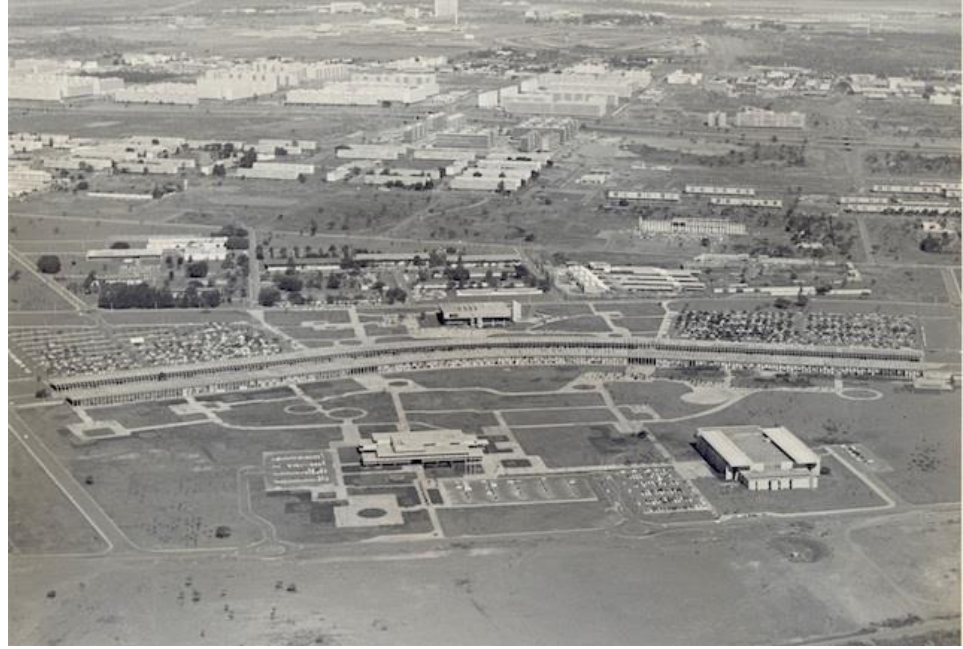

Figura 59- Vista do campus da UnB, sem data. (Fonte:

http://campus.fac.unb.br/arquivo/campus12014/universidade/item/2213especial-arquitetura-na-universidade-de-bras\%C3\%ADlia, acessado dia 24 de julho de 2016, as 12:20 horas). 

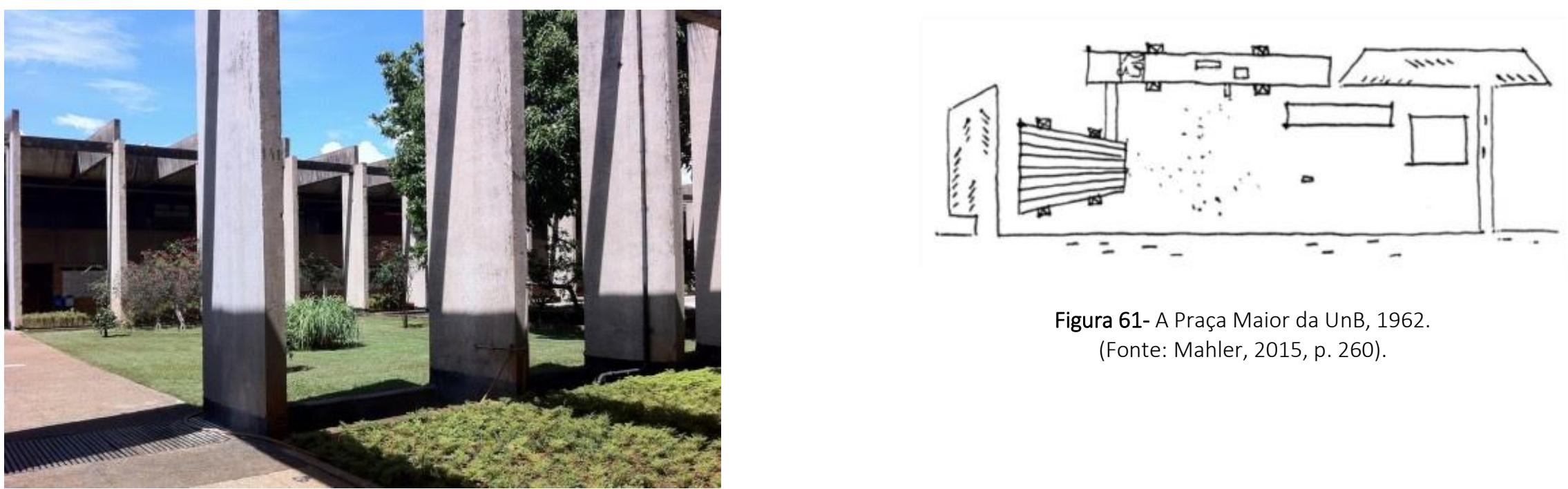

Figura 61- A Praça Maior da UnB, 1962. (Fonte: Mahler, 2015, p. 260).

Figura 60- Instituto Central de Ciências, o “Minhocão” de Niemeyer, 1962. (Fonte:

http://www.vitruvius.com.br/revistas/read/arquitextos/16.184/5684, acessado dia 24 de julho de 2016, as 13:41 horas). 


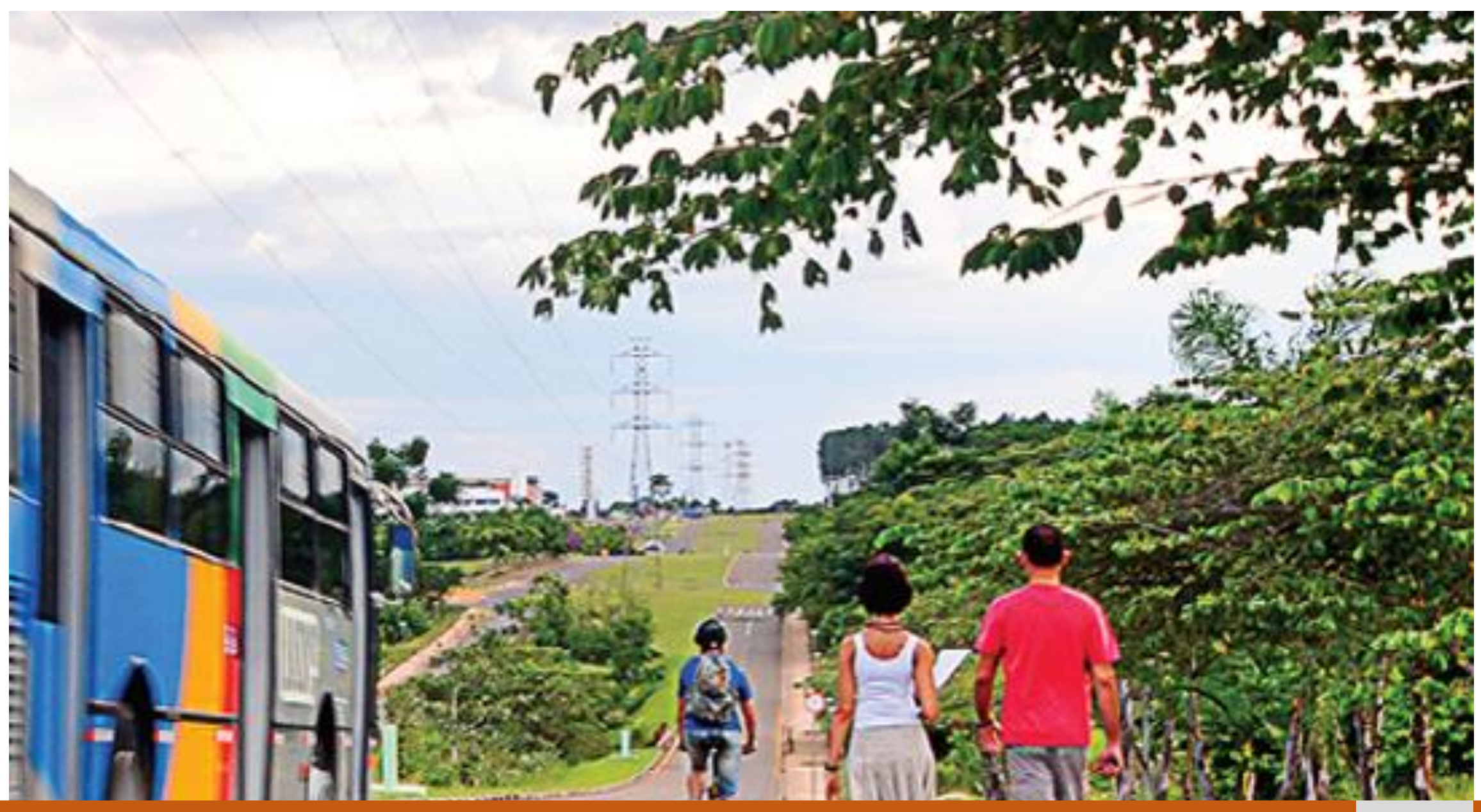

CAMPI E SUSTENTABILIDADE: INVESTIGAÇÃO E ESTUDO DE CASO 5 
Campus 2 da Universidade de São Paulo, São Carlos.

Fonte da imagem: RUSCHEINSKY, A. (org.). Ambientalização nas instituições de educação superior no Brasil: caminhos trilhados, desafios e possibilidades. São Carlos: EESC/ USP, 2014. 350 p. Imagem da capa. Editada pela autora. 


\section{CAMPI E SUSTENTABILIDADE: INVESTIGAÇÃO E ESTUDO DE CASO}

Se o moderno e a modernidades foram a pauta da construção em um período de ruptura com o campus histórico, a perspectiva contemporânea apresenta novos desafios e, por esse motivo é tão importante as iniciativas ligadas à sustentabilidade dentro dos espaços universitários.

O campus universitário possui uma grande responsabilidade em termos de impactos ambientais, sociais, culturais e políticos, influenciando, principalmente através de sua população e usuários, a cidade onde está inserida.

Os territórios universitários podem ser compreendidos como pequenos núcleos urbanos compostos por complexas infraestruturas e distintas atividades que impactam e demandam recursos naturais.

Para um campus ser considerado sustentável é preciso que esse ideário seja associado tanto à questões operacionais quanto as do ensino, da pesquisa e da gestão institucional. Em outras palavras, o foco não está apenas nas questões energéticas, de recursos ou de resíduos, todas essas questões se relacionam à sustentabilidade, mas essa não se completa sem incluir toda a comunidade interna e externa de maneira que estejam unidas pela promoção do bem estar da atual e futuras gerações (Disterheft et al, 2012).

Autores que tratam sobre a sustentabilidade no ensino superior afirmam que uma universidade sustentável deve abranger a educação, a pesquisa, a gestão do campus, a extensão, as diretrizes institucionais e as vivências dentro do campus de acordo com as dimensões sustentáveis.

Velazquez et al. (2006, p. 811) explicam o termo 'Universidade Sustentável' como uma instituição de ensino superior que esteja comprometida com a mínima geração de impactos ambientais, sociais, econômicos e de saúde que ocorrem como consequência de suas atividades e que, além disso, também é uma instituição que se preocupa em auxiliar a comunidade durante o processo de adoção de posturas sustentáveis.

Segundo Ferrer-Balas et. al.(2008) as características principais

para uma universidade sustentável são: uma educação 
transformativa que prepara estudantes para desafios sustentáveis complexos, uma forte influência em ciência e pesquisa trans e interdisciplinar, orientação para solução de problemas sociais, redes de contatos por todo o campus que possam trocar experiências, líderes e visionários que irão apresentar os desafios aos estudantes e supervisioná-los na solução.

É de vital importância, portanto, compreender as universidades como "pequenos núcleos urbanos" e refletir acerca de suas necessidades sobre novas bases, contemporâneas de pensamento relacionadas à sustentabilidade, como o estabelecimento de redes de infraestruturas como coleta e distribuição de água e oferecimento de energia elétrica (Tauchen e Brandli, 2006, p. 505) $)^{112}$.

Contudo, uma universidade sustentável deve levar em conta os conceitos apresentados por Sachs unindo as dimensões do ensino, pesquisa, administração e gestão da universidade e vivências sustentáveis no próprio espaço universitário. Segundo Velazquez et al. (2006, p. 811), a definição de uma universidade sustentável é:

\footnotetext{
${ }^{112}$ Segundo Bonett et al. (2002), o consumo per capita de água no campus de uma universidade próxima a Bordeaux, França, é maior do que a média urbana, fator
}

"Uma instituição de ensino superior, como um todo ou em parte, que busque a promoção, a nível regional ou global, da minimização de impactos negativos ambientais, sociais, econômicos e à saúde gerados pelo uso dos seus recursos quando do cumprimento de suas funções de ensino, pesquisa, extensão e manutenção de forma a ajudar a sociedade a fazer a transição para estilos de vida sustentáveis".

Vários autores analisam os processos de transição das universidades em universidades sustentáveis, indicando e ponderando aspectos que facilitam e que dificultam esse processo de mudanças dentro das instituições; dentre os fatores que dificultariam a implementação e a institucionalização da sustentabilidade nas universidades são destacados por pesquisadores da área: (1) as resistências às mudanças e à inovação; (2) as barreiras enfrentadas dentro das próprias instituições; e (3) a limitação do conceito de sustentabilidade por parte dos gestores. Apesar dessas questões, há os aspectos que promovem a implementação da sustentabilidade nas universidades segundo outros pesquisadores da área: (1) a reverem suas posições em relação ao meio ambiente. 
formalização do compromisso da instituição com a sustentabilidade (Lozano et al., 2014); (2) a preocupação dos gestores e líderes com o tema; (3) o estabelecimento de uma forma consistente de avaliar o desempenho institucional em relação à sustentabilidade (Amaral et al., 2015); (4) a participação dos professores e funcionários; (5) e a inclusão da sustentabilidade nos currículos.

Já alguns fatores são catalizadores no processo de implantação da sustentabilidade em universidades (Ferrer-Balas et al. 2008): as lideranças visionárias que se apropriam de projetos e responsabilidades fazendo com que os projetos aconteçam, os profissionais que atuam como "lobos solitários" na universidade tentando promover a mudança em seu campo de atuação, as pessoas que servem de conexão entre profissionais que atuam sozinhos em diferentes grupos, o tamanho da universidade que pode dificultar o processo, a existência de um órgão para cuidar da sustentabilidade, pressão por parte de instituições externas à universidade e, por fim, financiamento externo com objetivo de desenvolver projetos.

\subsection{Diretrizes para a promoção da Sustentabilidade em um campus}

O campus que deseja ser sustentavelmente responsável deve 'pensar globalmente e agir localmente', ou seja, deve começar pensando em seu espaço físico e suas áreas vizinhas de influência direta para depois interferir e adaptar seus métodos de ensino, disciplinas, pesquisa, projetos de extensão e gerenciamento.

Segundo Oliveira (2009, p. 24) não é mais suficiente apenas as ações locais para a resolução da crise ambiental, é preciso associar com iniciativas públicas e privadas que visam a "sustentabilidade ambiental, social e econômica".

As universidades e seus campi devem estar preparadas para receber e formar seus alunos a partir de posturas e ensinamentos práticos e teóricos voltados para a sustentabilidade.

Alguns objetivos e medidas foram alinhados durante a Conferência em Desenvolvimento Humano, 1972, e a Conferência do Meio Ambiente e Desenvolvimento, 1992, e que são possíveis aplicalos ao ensino, pesquisa, extensão e gestão institucional de 
universidades, antes mesmo de se pensar no espaço físico da universidade (Tabela 4).

A Auditing Instrument for Sustainability in Higher Education, criada pela Fundação Europeia de Gestão da Qualidade considera cinco pontos primordiais para a promoção da sustentabilidade em universidades: (a) a criação de atividades pontuais e isoladas; (b) criação de atividades coletivas de curto prazo; (c) criação de ações sistêmicas de médio prazo e com metas estabelecidas; (d) criação de ações de longo prazo voltadas para atuadores externos; (e) criação de ações a longo prazo voltadas para a sociedade e com avaliação externa (Roorda, 2001).

Já Velasquez et al. (2006) apresenta quatro fases para a promoção da sustentabilidade em um campus: (a) o desenvolvimento de uma visão acerca da sustentabilidade para toda a universidade; (b) a inclusão da sustentabilidade nas missões e objetivos institucionais; (c) a criação de um comitê voltado para a sustentabilidade cujo objetivo é o estabelecimento de políticas, objetivos e coordenação de iniciativas; (d) a implementação de estratégias sustentáveis voltadas para a educação, a pesquisa, as atividades de extensão e a gestão do campus.
Para Lozano (2006) o monitoramento e a avaliação das ações sustentáveis são essenciais para a transição de um campus para um campus sustentável.

As principais estratégias utilizadas na Europa que inseriram a sustentabilidade em seus campi são a top-down, ou de cima para baixo, denotando poder centralizado e não consecutivo, e a participativa, a principal conclusão tirada dessas estratégias é que a ação participativa é mais abrangente pois visa a melhoria ambiental da instituição e a melhor maneira de incorporar a sustentabilidade em vários níveis de atuação no campus, principalmente na questão da formação estudantil (Disterheft et el., 2012).

Distintos autores analisam a transição das universidades, o fator que mais dificulta a implementação e institucionalização é a resistência às mudanças e à inovação, as barreiras institucionais criadas em relação às mudanças, a limitação ou incompreensão que os gestores têm sobre conceito de sustentabilidade e os problemas na condução do processo participativo para a institucionalização da sustentabilidade. Por outro lado, existem os fatores que contribuem para a institucionalização da sustentabilidade que é a formalização do compromisso da universidade com a sustentabilidade, o 
compromisso dos gestores com o tema, a criação de uma forma de avaliação e desempenho institucional em relação à sustentabilidade, processo participativo para a implementação da sustentabilidade e a inclusão da temática nos currículos de forma crítica, ampla, transversal, interdisciplinar e completa (Lozano, 2006; Pereira et al., 2013; Wright e Horst, 2013; Disterheft et el., 2014; Lozano et al., 2014; Burford et al., 2013; Amaral et al., 2015; Disterheft et el., 2012; Brinkhurst et al., 2011; Levy e Marans, 2011; Segalàs et al., 2012).

A tabela a seguir apresenta as ações iniciais apresentadas pela ONU às universidades que almejam alcançar a sustentabilidade, através da apresentação de documentos importantes, seus objetivos e como aplicar na instituição.

\begin{tabular}{|c|c|c|}
\hline Documento & Objetivos & Medidas Recomendadas \\
\hline $\begin{array}{l}\text { Conferência em } \\
\text { Desenvolvimento } \\
\text { Humano (1972) e } \\
\text { Declaração de } \\
\text { Estocolmo }\end{array}$ & $\begin{array}{l}\text { Prevenir e/ou minimizar } \\
\text { aspectos contrários ao } \\
\text { Desenvolvimento } \\
\text { Sustentável. }\end{array}$ & $\begin{array}{c}\text { Formulação de acordos } \\
\text { multi e bilaterais, ou de } \\
\text { outras formas de } \\
\text { cooperação } \\
\text { (nomeadamente em } \\
\text { transferência } \\
\text { tecnológica). }\end{array}$ \\
\hline $\begin{array}{c}\text { Conferência do Meio } \\
\text { Ambiente e }\end{array}$ & $\begin{array}{l}\text { Envolver todos na } \\
\text { educação para o }\end{array}$ & $\begin{array}{c}\text { Envolvimento de } \\
\text { decisores no governo, }\end{array}$ \\
\hline
\end{tabular}

\begin{tabular}{|c|c|c|}
\hline $\begin{array}{l}\text { Desenvolvimento } \\
\text { (1991)- Relatório do } \\
\text { Comitê Preparatório }\end{array}$ & $\begin{array}{l}\text { Desenvolvimento } \\
\text { Sustentável. }\end{array}$ & $\begin{array}{l}\text { de especialistas que os } \\
\text { aconselhem nas } \\
\text { universidades, institutos } \\
\text { de pesquisa, entre } \\
\text { outros. }\end{array}$ \\
\hline $\begin{array}{c}\text { Conferência do Meio } \\
\text { Ambiente e } \\
\text { Desenvolvimento } \\
\text { (1992)- Declaração do } \\
\text { Rio }\end{array}$ & $\begin{array}{c}\text { Fortalecer o } \\
\text { desenvolvimento de } \\
\text { competências para o } \\
\text { Desenvolvimento } \\
\text { Sustentável. }\end{array}$ & $\begin{array}{l}\text { Intercâmbio de } \\
\text { conhecimento científico } \\
\text { e tecnológico. } \\
\text { Desenvolvimento, } \\
\text { adaptação, difusão e } \\
\text { transferência de } \\
\text { tecnologias, incluindo as } \\
\text { novas e inovadoras. }\end{array}$ \\
\hline & $\begin{array}{l}\text { Tornar claro o papel da } \\
\text { ciência e tecnologia no } \\
\text { Desenvolvimento } \\
\text { Sustentável. }\end{array}$ & $\begin{array}{c}\text { (Re)desenho dos } \\
\text { programa nacionais em } \\
\text { Ciências e Tecnologia de } \\
\text { forma a tornar claras as } \\
\text { contribuições do setor } \\
\text { para o Desenvolvimento } \\
\text { Sustentável; identificar } \\
\text { funções/ } \\
\text { responsabilidades do } \\
\text { setor no }\end{array}$ \\
\hline
\end{tabular}




\begin{tabular}{|c|c|c|}
\hline $\begin{array}{c}\text { Conferência do Meio } \\
\text { Ambiente e }\end{array}$ & & $\begin{array}{c}\text { desenvolvimento } \\
\text { humano. }\end{array}$ \\
\hline $\begin{array}{l}\text { Desenvolvimento } \\
\text { (1992)- Agenda } 21\end{array}$ & $\begin{array}{c}\text { Gerar e disseminar } \\
\text { conhecimento e } \\
\text { informação em } \\
\text { Desenvolvimento } \\
\text { Sustentável. }\end{array}$ & $\begin{array}{l}\text { Produção de avaliações } \\
\text { científicas de longo- } \\
\text { prazo sobre o consumo } \\
\text { de recursos, uso da } \\
\text { energia, impactos na } \\
\text { saúde e tendências } \\
\text { demográficas, a tornar } \\
\text { públicas em formas } \\
\text { amplamente } \\
\text { compreendidas. }\end{array}$ \\
\hline & $\begin{array}{c}\text { Educar todos para o } \\
\text { Desenvolvimento } \\
\text { Sustentável. }\end{array}$ & $\begin{array}{c}\text { Desenvolvimento de } \\
\text { programas de educação } \\
\text { em ambiente e } \\
\text { desenvolvimento } \\
\text { (acessível a pessoas de } \\
\text { todas as idades). } \\
\text { Incentivos dos países às } \\
\text { universidades e a redes } \\
\text { de trabalho neste } \\
\text { âmbito. }\end{array}$ \\
\hline
\end{tabular}

Tabela 4- Sinais iniciais apresentados pela ONU às universidades sustentáveis (1972- 1992).

(Fonte: adaptado de Oliveira, 2009, p. 29).
Para a melhor compreensão de quais são as diretrizes para a promoção da sustentabilidade em um campus são apresentadas de maneira mais completa as quatro linhas utilizadas para a transformação e promoção de um território universitário sustentável que são: (a) o compromisso institucional; (b) o planejamento físico; (c) a gestão institucional e (d) o ensino para a sustentabilidade.

\subsubsection{Compromisso Institucional}

É imprescindível que haja por parte da gestão institucional a consciência, compreensão e compromisso com todas as vertentes da sustentabilidade.

Distintos autores (Barbieri, 2007; Donaire, 1995; Oliveira, 2006; PNUMA, 1999; Seiffert, 2007; Tinoco e Kraemer, 2007; Oliveira, 2009) e a norma ISSO 14.001 falam sobre a importância do comprometimento da gestão de ensino superior para a promoção da sustentabilidade em um campus pois são eles os responsáveis pela viabilização de recursos, pessoas e tempo.

Esse compromisso é frisado pela participação dos membros da gestão em discussões sobre a sustentabilidade no campus. 
Além disso a gestão é responsável por outro importante fator que é a definição de uma política de avaliação ambiental para a instituição de acordo com a NBR ISSO 14.001, essa política deve englobar a natureza e a comunidade presente no campus.

Segundo Oliveira (2009) apresenta um organograma viável a ser implantado por uma gestão institucional que almeja transformar seu campus em um espaço sustentável:

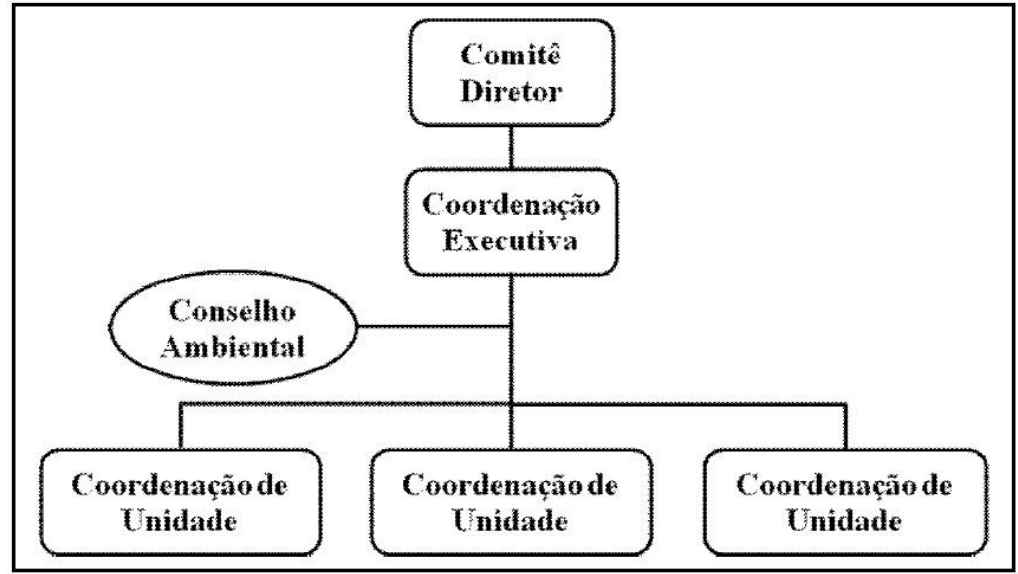

Figura 62- Organograma estrutural adaptado da Universidade Federal do Rio Grande do Sul.

(Fonte: Oliveira, 2009, p. 29).

113 Ainda segundo o autor (Oliveira, 2009), cada comitê possui sua função determinada com atribuições e áreas de atuação.
O organograma apresentado foi criado a partir de iniciativas implantadas na Universidade Federal do Rio Grande do Sul e que serve como importância referência; o organograma foi criado de maneira genérica pelo autor citado para poder ser adaptado por qualquer reitoria universitária que deseje criar os comitês apresentados para iniciar as ações voltadas para a sustentabilidade no campus ${ }^{113}$.

O autor exemplifica na tabela a seguir as propostas de formação e ações para cada comitê:

\begin{tabular}{|c|c|c|}
\hline Órgão & Composição & Função \\
\hline $\begin{array}{l}\text { Comitê } \\
\text { Diretor }\end{array}$ & $\begin{array}{lr}\text { Reitor, } & \text { Vice-Reitor, } \\
\text { Coordenador de Gestão } \\
\text { Ambiental, Pós- Reitores e } \\
\text { Secretários, } \\
\text { representantes }\end{array}$ & $\begin{array}{l}\text { Orientar de forma geral a } \\
\text { implantação do Sistema } \\
\text { de Gestão Ambiental, } \\
\text { como a aprovação de } \\
\text { Normativas e Diretrizes, e } \\
\text { demais ações visando sua } \\
\text { execução }\end{array}$ \\
\hline $\begin{array}{c}\text { Coordenação } \\
\text { Executiva }\end{array}$ & $\begin{array}{l}\text { Coordenador de Gestão } \\
\text { Ambiental, } \\
\text { Coordenador Adjunto e } \\
\text { demais Coordenadores } \\
\text { dos Órgãos e Projetos }\end{array}$ & $\begin{array}{l}\text { Possui caráter executivo, } \\
\text { devendo implantar o } \\
\text { Sistema de Gestão } \\
\text { Ambiental, através do } \\
\text { desdobramento dos }\end{array}$ \\
\hline
\end{tabular}




\begin{tabular}{|c|c|c|}
\hline & $\begin{array}{l}\text { participantes da } \\
\text { Coordenadoria de Gestão } \\
\text { Ambiental }\end{array}$ & $\begin{array}{l}\text { Planos de Ação do } \\
\text { planejamento ambiental } \\
\text { ou a articulação da } \\
\text { execução de atividades } \\
\text { específicas, como o } \\
\text { gerenciamento de } \\
\text { resíduos, e também } \\
\text { encaminhar ao Comitê } \\
\text { Diretor propostas de } \\
\text { Normativas e Diretrizes }\end{array}$ \\
\hline $\begin{array}{l}\text { Conselho } \\
\text { Ambiental }\end{array}$ & $\begin{array}{l}\text { Todos os agentes } \\
\text { ambientais, } \\
\text { representantes dos } \\
\text { servidores técnicos e } \\
\text { administrativos, } \\
\text { representantes docentes } \\
\text { e pesquisadores de temas } \\
\text { afins, representantes } \\
\text { discentes, e } \\
\text { representantes da } \\
\text { instituição em órgãos } \\
\text { externos com ação nas } \\
\text { áreas da sustentabilidade }\end{array}$ & $\begin{array}{l}\text { Subsidiar as discussões } \\
\text { metodológicas, bem como } \\
\text { as Diretrizes e Normativas, } \\
\text { propondo também os } \\
\text { grandes temas a serem } \\
\text { debatidos para o } \\
\text { aprofundamento da } \\
\text { prática ambiental em } \\
\text { todos os âmbitos da } \\
\text { instituição. Acompanhar o } \\
\text { desempenho do Sistema } \\
\text { de Gestão Ambiental }\end{array}$ \\
\hline $\begin{array}{l}\text { Coordenação } \\
\text { de Unidade }\end{array}$ & $\begin{array}{lll}\text { Agentes } & \text { Ambientais } & \text { de } \\
\text { cada unidade } & \text { da } \\
\text { instituição } & & \end{array}$ & $\begin{array}{l}\text { Implantar o Sistema de } \\
\text { Gestão Ambiental nas } \\
\text { respectivas unidades, } \\
\text { aplicando os elementos do } \\
\text { planejamento ambiental, } \\
\text { medindo e informando a }\end{array}$ \\
\hline
\end{tabular}

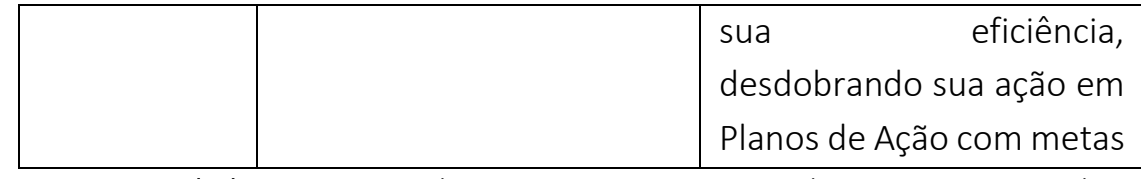

Tabela 5- Proposta de organização institucional para a promoção da sustentabilidade em um campus.

(Fonte: Oliveira, 2009, p. 29).

É possível concluir, então, que o compromisso da gestão ambiental favorece a concretização e sucesso do planejamento de ações para o campus, é importante a presença de pessoas que tenham participação em outros órgãos e conselhos ambientais para a ampla troca de experiências.

"O envolvimento de indivíduos (...) de cada setor é fundamental para a mudança de atitude. (...) a postura proativa de alguns setores (...) acaba por estimular (...)

a mudança de comportamento de setores mais resistentes" (Seiffert, 2007, p. 133).

A tabela a seguir apresenta as diretrizes para a concretização do compromisso institucional. 


\begin{tabular}{|c|c|c|}
\hline \multirow{5}{*}{ 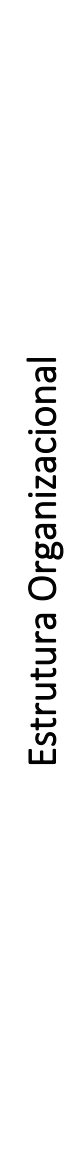 } & Diretrizes & Ações \\
\hline & $\begin{array}{l}\text { Comprometimento da } \\
\text { alta administração }\end{array}$ & $\begin{array}{l}\text { Prover a instituição dos recursos } \\
\text { necessários para a implantação da } \\
\text { gestão ambiental. Assumir a } \\
\text { dimensão ambiental na estratégia } \\
\text { organizacional }\end{array}$ \\
\hline & Política ambiental & $\begin{array}{l}\text { Definir a política ambiental da } \\
\text { instituição, demonstrando } \\
\text { compromisso com o atendimento aos } \\
\text { requisitos legais e com a melhoria } \\
\text { contínua }\end{array}$ \\
\hline & Organograma & $\begin{array}{l}\text { Definir os elementos e o papel de } \\
\text { cada um deles dentro da } \\
\text { coordenação da gestão ambiental }\end{array}$ \\
\hline & Formação de agentes & $\begin{array}{l}\text { Capacitar as pessoas para atuarem } \\
\text { com responsabilidade ambiental } \\
\text { formar colaboradores para a gestão } \\
\text { ambiental }\end{array}$ \\
\hline
\end{tabular}

Tabela 6- diretrizes para a concretização do compromisso institucional. (Fonte: Oliveira, 2009, p. 56).

\subsubsection{Planejamento Físico}

O planejamento físico de um campus engloba a infraestrutura, edifícios, vias, áreas verdes e espaços vazios. Esses espaços devem estar integrados com as políticas educacionais e sociais para a promoção da sustentabilidade.

Para um campus ser sustentável é preciso que a sustentabilidade esteja aplicada de maneira inter e multidisciplinar durante os processos de planejamento.

Universidades que estão construindo novas instalações possuem a oportunidade de optar por um estilo de construção sustentável, que respeite as interações sociais, e que possuam um sistema de gestão mais sustentável levando em consideração a questão ambiental.

Para Fowler e Aguiar (1995 apud Oliveira, 2009) é preciso considerar de maneira igualitária os aspectos ambientais, sociais e econômicos durante o planejamento do campus. Sotelo e Sal (2008 apud Oliveira, 2009) afirmam que o planejamento de campus que leva em conta as questões ambientais e territoriais preserva a formação integra do ser humano. Ambos afirmam que o planejamento do 
território universitário sustentável deve se preocupar além da questão do espaço físico, levando em grande consideração na qualidade desses espaços que acabam por também influenciar o ensino. O importante é harmonizar o meio ambiente, o ensino e a arquitetura.

A Universidade de Alcalá, na Espanha, adotou posturas em seu campus integradas com o meio ambiente:

"como as lagoas que ajudam a regular o microclima; edifícios eficientes do ponto de vista energético (...) e que empregam materiais reciclados; e a escolha correta das espécies utilizadas na arborização (...) escolhidas a partir de condições locais, a fim de transmitir valores locais e serem sustentáveis, precisando de quase nenhuma manutenção. Sua disposição inteligente em todo o campus pode ser uma ferramenta para fornecer sombras" (Sotelo e Sal, 2008, p. 07 apud Oliveira, 2009, p. 57)

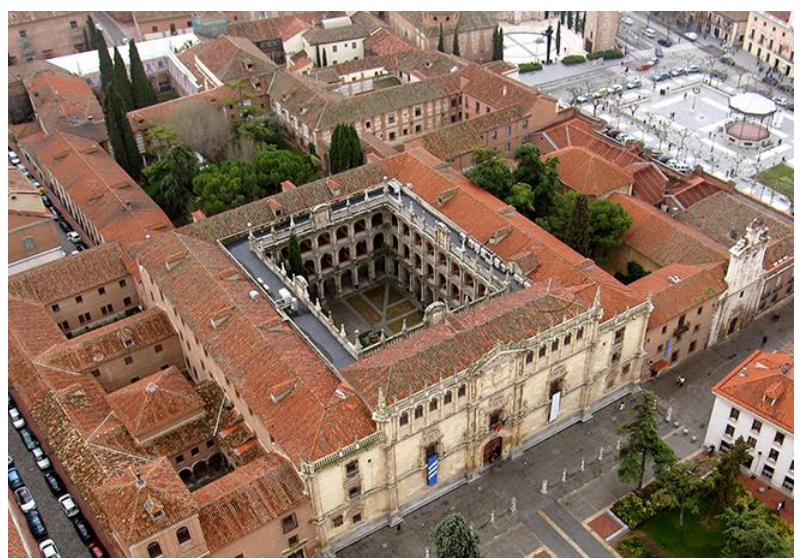

Figura 63- Parte da Universidade de Alcalá.
(Fonte: http://visitasalcala.es/, acessado dia 04 de setembro de 2016, as 20:54 hrs).

Outro exemplo apresentado por Oliveira $(2009$, p. 57) é a reconfiguração do campus da Universidade de Tecnologia Chalmers, Suécia, que sofreu uma modificação baseada em "re-engenharia ecológica" onde os estacionamentos que antes eram pavimentados passaram a ser áreas verdes, excluindo os perigos do tráfego e das emissões de poluentes. Os alunos passaram a utilizar das áreas verdes, que agora são um espaço mais limpo e seguro, como um espaço de descanso e lazer.

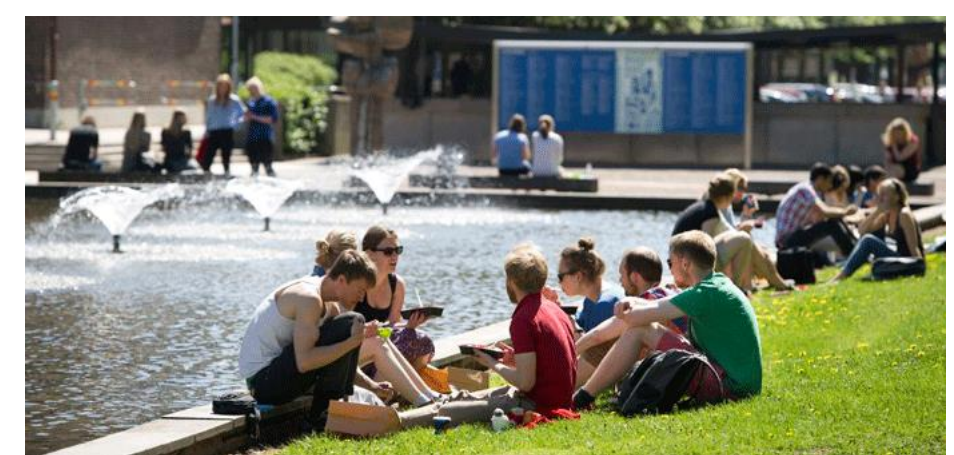

Figura 64- Estudantes descansando em áreas de estar da Universidade de Tecnologia Chalmers.

$$
\text { (Fonte: }
$$

https://student.portal.chalmers.se/en/chalmersstudies/newstudent/firstweeksatc halmers/Pages/default.aspx, acessado dia 04 de setembro de 2016, as 21:02 hrs). 
Os exemplos apresentados mostrar a relação entre os aspectos físicos, biológicos, sócio-econômicos e de gestão de campi.

Compreendendo o campus como uma pequena cidade cujas atividades, estrutura, uso de água, diversidade ecológica, empobrecimento dos solos, desmatamentos, tráfego, esgoto, resíduos, abastecimento de água, instituições e valore sociais impactam não só o meio ambiente, mas também a cidade onde está inserido, a importância do planejamento sustentável é imprescindível para o alcanço de um equilíbrio.

É preciso que o campus também se preocupe com o controle e o tratamento da poluição visando reduzir os impactos ambientais gerados por ele como a instalação de Estações de Tratamento de Efluentes, o tratamento de emissões atmosféricas resultantes de usos laboratoriais, restaurantes, veículos e resíduos sólidos, entre outras iniciativas.

Um campus normalmente ocupa um grande terreno urbano e que, resultante do crescimento das cidades, acaba sendo rodeado por edifícios comerciais e residenciais; esse fato somado à especulação imobiliária acaba por reduzir os espaços verde e aumentar o trânsito local, aqui é um exemplo da importância da aplicação do Plano Diretor Universitário.

O campus também não deve deixar de ser um local que receba e acolha a população vizinha, vivendo harmonicamente com a dinâmica urbana e se relacionando com seu entorno.

A tabela a seguir apresenta as diretrizes para o planejamento físico de um campus sustentável.

\begin{tabular}{|c|c|}
\hline Diretrizes & Ações \\
\hline $\begin{array}{l}\text { Considerar a variável } \\
\text { ecológica na gestão do } \\
\text { espaço }\end{array}$ & $\begin{array}{l}\text { Definir o ordenamento ambiental e } \\
\text { territorial dentro de um Plano diretor, } \\
\text { considerando o campus universitário } \\
\text { como um núcleo urbano integrado à } \\
\text { malha local, em sintonia com a } \\
\text { organização e dinâmica da cidade }\end{array}$ \\
\hline Uso e ocupação do solo & $\begin{array}{l}\text { Conciliar o atendimento das } \\
\text { necessidades institucionais com a } \\
\text { qualidade ambiental, respeitando } \\
\text { também as relações sociais }\end{array}$ \\
\hline $\begin{array}{l}\text { Implantação e preservação } \\
\text { de áreas verdes }\end{array}$ & $\begin{array}{l}\text { Considerar sua importância para a } \\
\text { regularização do microclima, qualidade } \\
\text { do ar, aspectos culturais, lazer, áreas } \\
\text { para reflexão e interiorização }\end{array}$ \\
\hline Edificações ecoeficientes & $\begin{array}{l}\text { Implantar técnicas e tecnologias para o } \\
\text { conforto térmico, principalmente por } \\
\text { meio de recursos passivos climáticos }\end{array}$ \\
\hline
\end{tabular}




\begin{tabular}{|l|l|}
\hline \multirow{5}{*}{} & $\begin{array}{l}\text { (ventilação, aproveitamento da luz } \\
\text { natural). Aproveitamento da água da } \\
\text { chuva, economia de energia e água, } \\
\text { redução nos custos de manutenção. } \\
\text { Uso de materiais menos impactantes e } \\
\text { recursos renováveis }\end{array}$ \\
\hline Infraestrutura & $\begin{array}{l}\text { Projetar redes de utilidades (energia, } \\
\text { água, gás, telecomunicações), rede } \\
\text { viária e acessos às instalações } \\
\text { considerando as variáveis ambientais e } \\
\text { sociais }\end{array}$ \\
\hline Controle ambiental & $\begin{array}{l}\text { Projetar e implantar sistemas para } \\
\text { evitar, reduzir, e ainda, controlar e } \\
\text { tratar a poluição do ar, solo e recursos } \\
\text { hídricos }\end{array}$ \\
\hline Pressão imobiliária & nofinir ações para mitigar os impactos \\
entorno & $\begin{array}{l}\text { provenientes da expansão imobiliária } \\
\text { no entorno da instituição. Desenvolver } \\
\text { mecanismos de integração urbana com } \\
\text { o entorno }\end{array}$ \\
\hline
\end{tabular}

Tabela 7- diretrizes para o planejamento físico de um campus sustentável. (Fonte: Oliveira, 2009, p. 64).

\subsubsection{Gestão Operacional da Instituição de Ensino} Superior
Para que o planejamento de uma universidade sustentável possa ocorrer de maneira efetiva é preciso que haja uma forte gestão operacional.

A gestão operacional irá trabalhar dentro das questões ambientais não permitindo que outros órgãos da instituição contraírem mais do que essas diretrizes. Além disso é importante que essa gestão se preocupe com os recursos materiais e humanos, "apoiando, gerenciando e politicamente, as ações propostas" (Oliveira, 2009, p. 64).

Qualquer instituição de ensino superior gasta e gera uma alta quantidade de materiais, alguns provenientes de laboratórios são considerados perigosos e necessitam de um maior controle para que não ocorram acidentes, sobretudo ambientais e humanos; materiais de construção também são importantes exemplos de resíduos de materiais poluentes que podem contaminar os lenções freáticos se foram descartados de forma errônea.

Essa é a importância de uma atuação sistêmica da gestão operacional institucional voltada para as questões socioambientais.

"Uma gestão ambiental universitária deve implantar uma política de compras e contratações para 
desenvolver fornecedores que adotem boas práticas de gestão ambiental, que se encontrem legalmente habilitados (licenciamento ambiental e demais autorizações pertinentes) e comprometidos com a sustentabilidade de suas atividades. A variável econômica, de uma forma geral, é preponderante na tomada de decisão, envolvendo compras e contratações de serviços. Todavia, (...) o menor preço para a instituição poderá estar relacionado com um maior custo ambiental e social (...). A sustentabilidade deve buscar o equilíbrio entre a eficiência econômica e ambiental, com justiça social. E por isso, a necessidade de desenvolver redes de fornecedores sustentáveis é uma questão evidente na gestão ambiental universitária que favorece, além da adequação da instituição, a promoção do comprometimento com a sustentabilidade nos demais elementos ao longo da cadeia de processos" (Oliveira, 2009, p. 65).

É possível que as ações adotadas sejam as inspiradas por modelos que já foram aplicados e foram um modelo de sucesso em outras instituições, é a Produção Mais Limpa, PML. Juntamente com a Prevenção da Poluição, essas gestões conjuntas cumprem as necessidades ambientais e garantem a promoção do desenvolvimento sustentável.

${ }^{114}$ A Associação Brasileira de Normas Técnicas, ABNT, criou a Norma Brasileira, NBR, 10004 em 2004 que classifica os resíduos sólidos; as NBR 10005, 10006 e 10007 apresentam os procedimentos para a obtenção de extrato lixiviado de resíduos sólidos, para a obtenção de extrato solubilizado de resíduos sólidos e amostragens de resíduos sólidos. As classificações dos resíduos ocorrem de acordo com os processos ou atividade que lhes deram origem, seus constituintes e
Em 1989 o Programa das Nações Unidas para o Meio Ambiente, PNUMA, propôs o programa Produção Mais Limpa, que visava a aplicação de uma estratégia ambiental integrada a processos, produtos e serviços cuja finalidade é reduzir os riscos à humanidade e ao meio ambiente. Para tudo isso seja possível, a Produção Mais Limpa deve envolver o uso de novas tecnologias para a elaboração de produtos e processos, mudanças de atitudes e o uso de 'boas práticas' de produção (PNUMA, 1999).

Assim, a gestão de resíduos sólidos precisa englobar a redução de sua geração com técnicas simples; laboratórios, restaurantes, oficinas, obras e oficinas devem aplicar as técnicas para reduzir seus resíduos e seus consumos de materiais e energia.

Os materiais perigosos a serem descartados, como lâmpadas, óleos e resíduos químicos devem ser:

"classificados conforme a NBR $10004^{114}$ e os resíduos
de serviço de saúde, devem ser separados,
armazenados, transportados e destinados
corretamente, conforme normas técnicas e legislação

características e com a comparação destes resíduos com listagens de resíduos e substâncias cujo impacto à saúde e ao meio ambiente é conhecido (pera maiores informações

acessar

abetre/classificacao-de-residuos) 
pertinentes. Os resíduos recicláveis devem ser destinados para tal" (Oliveira, 2009, p. 66).

Reciclar materiais é também uma iniciativa positiva para favorecer os aspectos sociais e econômicos ligados à sustentabilidade. As instituições de ensino superior através do incentivo da reciclagem apoiam famílias envolvidas com esse tipo de trabalho, além de poderem colaborar com ensinamentos de gestão, cooperativismo e liderança (Oliveira, 2009).

Outra iniciativa importante citada pelo mesmo autor é o uso da compostagem dos resíduos orgânicos provenientes de espaços de alimentação e jardinagem que resultam em adubo para as áreas verdes.

Os campi também devem contar com estações de tratamentos de efluentes para esgotos provenientes não somente de sanitários, mas de laboratórios e outras instalações do campus, para evitar a poluição de rios e sobrecarga das estações municipais de tratamento de esgoto. Essas estações para tratamento de esgotos universitários também podem ser vistas como um laboratório para alguns cursos (Oliveira, 2009).

Outra ação importante é o controle do consumo de energia a partir de adequação de aparelhos eletrônicos e lâmpadas, aumentando sua eficiência e racionando seu consumo. Para que isso ocorra de forma efetiva é necessário um bom planejamento da infraestrutura e o estabelecimento de edifícios ecoeficientes, que além da preocupação com o consumo energético também devem (re) aproveitar a água seja de chuva ou utilizada no próprio edifício.

Oliveira (2009) também fala sobre a manutenção da qualidade do ar nos campi a partir de ações redutoras de poluição em todas as áreas do território universitário, sobretudo no trânsito de veículos comunitários, como ônibus, que ao utilizarem de biocombustível ou reajustando seus motores reduzem a quantidade de poluentes, para veículos particulares a conscientização e atividades educativas são de importância fundamental. Um exemplo sempre citado e muito importante é a uso amplo de caronas solidárias, bicicletas e caminhadas, mais uma vez ações universitárias são importantes para viabilizar a segurança dessas duas últimas opções.

A conservação e tratamento das áreas verdes também não deve ser deixada de lado, é vital inclui-la no Plano de Manejo do campus com ações como:

"inventário florestal, definição de áreas a serem preservadas, cercamento e sinalização dessas áreas, substituição de espécies exóticas paisagísticas ou invasores por espécies nativas de valor regional, 
recomposição e recuperação de áreas degradadas, implantação ou adequação da arborização viária com espécies nativas, estabelecimento de medidas compensatórias para os casos de supressão vegetal (...), além das medidas de educação ambiental da comunidade universitária" (Oliveira, 2009, p. 70).

\subsubsection{Ensino para a Sustentabilidade}

Para Fouto (2002), a universidade tem um importante papel em relação ao Desenvolvimento Sustentável para a produção de conhecimentos e soluções aos problemas enfrentados neste sentido; essa solução deve vir em forma de pesquisas que geram conhecimentos e através do desenvolvimento e disseminação de novas tecnologias voltadas à sustentabilidade, através de redes de trabalhos. Além da pesquisa e de projetos de extensão, o ensino voltado para a sustentabilidade é importante e fundamental.

Assim, a universidade deve ensinar seus estudantes e influenciar órgãos responsáveis pela tomada de distintas decisões; isso só é possível com a adequação dos curriculares e através da cobrança dos governos e agentes sociais a respeito do compromisso social (Fouto, 2002).
O ensino só poderá ser revisto após a reorientação das disciplinas e criando novos modelos maleáveis para que, finalmente, possa ser possível solucionar os problemas ambientais e modificar as práticas sociais que não estão compatíveis com as vertentes sustentáveis.

As instituições de ensino superior ainda são muito pobres em relação ao ensino voltado para a sustentabilidade.

Nesta questão, as universidades encaram grandes desafios que á a formação de profissionais capazes de atuarem de forma interdisciplinar em distintas áreas de conhecimento e que sejam capazes de apresentarem soluções para os problemas ambientais (Philippi Júnior, Romério e Bruna, 2004).

São as universidades importantes instrumentos da transição para uma sociedade sustentável. Uma universidade sustentável deve:

(a) "Assumir sua função social"; (b) Incluir as vertentes sustentáveis em todas as disciplinas de seus vários cursos; (c) Mantes as disciplinas de maneira interdisciplinar; (d) "Promover novas estruturas nas universidades, tendo como objetivo concreto os problemas ambientais (...)"; (e) Incluir a temática em projetos de pesquisa elaboradas em parceria com empresas; (f) Criar soluções sustentáveis 
e estratégicas para a crise atual (Péres e Dulzaides, 2005, p. 02 apud Oliveira, 2009, p. 30-31).

O objetivo final do ensino voltado para a sustentabilidade (ambientalização curricular) é educar e conscientizar os futuros profissionais para que adicionem em todas as suas ações, profissionais e pessoais, as questões e resoluções sustentáveis e que possam auxiliar as sociedades a partir desses valores.

Segundo Oliveira (2009), no Brasil há a Lei Federal no 9.795/ 99 que aborda a Educação Ambiental ${ }^{115}$ e os currículos de maneira ampla, sistêmica, transversal e integrada nos vários cursos superiores.

Uma questão interessante a ser citada é o artigo 11 que afirma que para que o ensino da Educação Ambiental seja efetivo,

docentes devem se especializar ou se atualizar na área para a aplicação transversal nos currículos. Esse é um verdadeiro desafio visto que muitos docentes são verdadeiramente resistentes à essas questões e não estão abertos a interdisciplinaridade (Oliveira, 2009).

115 A educação ambiental assumiu um papel transformador, onde a coresponsabilização dos indivíduos é um objetivo essencial para a promoção de um desenvolvimento sustentável. A educação ambiental é, portanto, condição necessária para a modificação da degradação socioambiental. Entretanto só irá atingir seu objetivo se o educador souber construir as corretas referências
Nesse mesmo artigo é também apresentada a importância da ética ambiental nas atividades profissionais.

As instituições de ensino superior voltadas para a formação sustentável devem utilizar da Lei Federal no 9.394/96, Lei de Diretrizes e Bases da Educação Nacional:

"Art. 43. A educação superior tem por finalidade: (...) III- Incentivar o trabalho de pesquisa e investigação científica, visando o desenvolvimento de ciência e da tecnologia e da criação e difusão da cultura, e, desse modo, desenvolver o entendimento do homem e do meio em que vive; (...)

VI- Estimular o conhecimento dos problemas do mundo presente, em particular os nacionais e regionais, prestar serviços especializados à comunidade e estabelecer com esta uma relação de reciprocidade" (Brasil, 1996 apud Oliveira, 2009, p. 33).

A sustentabilidade nos currículos universitários deve aparecer de maneira transdisciplinar e holística, combinando sempre a pesquisa, a teoria e a disseminação da inovação curricular ${ }^{116}$.

Ainda segundo Oliveira (2009) as universidades devem ser modelos sociedades justas e sustentáveis a partir de atividades como

ambientais e utilizá-las como instrumentos para o desenvolvimento de uma pratica social centrada na natureza (Jacobi, 2003).

${ }^{116}$ Sachs (2008) fala sobre uma nova disciplina voltada para a sustentabilidade chamada 'eco-sócio-economia'. 
a construção civil, gestão de resíduos, operações institucionais, reciclagem da formação dos docentes e funcionários, ensino, e práticas socioambientais, pondo sempre em prática o que é ensinado em salas de aula em atividades acadêmicas, institucionais e administrativas. Também é necessário que o espaço físico e suas infraestruturas sejam uma lição de sustentabilidade.

Além dos currículos, o ensino voltado para a sustentabilidade deve se preocupar com pesquisas guiadas para os problemas de saúde, alimentos, sociedade, meio ambiente e gestão urbana e que, mesmo que não sejam diretamente ligados à sustentabilidade, possam contribuir para a formação humana dos alunos (Tomás, 2003). O importante é alinhar a pesquisa, ensino e projetos de extensão com as demandas sociais e o enfoque sustentável.

Já na questão da extensão de atividades universitárias é aberta a possibilidade de atividades ligadas com a sociedade seja em comunidades ou empresas cujo propósito é, sempre, aprender na prática e melhorar as comunidades e o meio ambiente dentro das vertentes apresentadas por Sachs (capítulo 2).

A tabela a seguir apresenta de forma breve as diretrizes voltadas para o ensino e a sustentabilidade:

\begin{tabular}{|c|c|c|}
\hline & Diretrizes & Ações \\
\hline & $\begin{array}{ll}\text { Disciplinas } & \text { de } \\
\text { sustentabilidade } & \end{array}$ & $\begin{array}{l}\text { Criar e integrar no currículo } \\
\text { disciplinas voltadas para a } \\
\text { sustentabilidade, considerando a } \\
\text { abordagem econômica, ambiental e } \\
\text { social }\end{array}$ \\
\hline & $\begin{array}{ll}\text { Cursos } & \text { de } \\
\text { sustentabilidade } & \end{array}$ & $\begin{array}{l}\text { Criar a implementar cursos } \\
\text { específicos para formar profissionais } \\
\text { nas áreas de licenciatura e } \\
\text { bacharelados para a educação } \\
\text { ambiental, gestão ambiental e } \\
\text { demais ciências e tecnologias } \\
\text { diversas relacionadas com a } \\
\text { sustentabilidade }\end{array}$ \\
\hline & $\begin{array}{l}\text { Transversalidade } \\
\text { curricular }\end{array}$ & $\begin{array}{l}\text { Incorporar a sustentabilidade de } \\
\text { forma transversal nos currículos, } \\
\text { incorporando suas dimensões no } \\
\text { projeto político-pedagógico }\end{array}$ \\
\hline 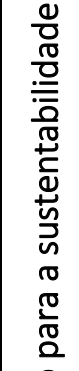 & $\begin{array}{l}\text { Formação } \\
\text { professores }\end{array}$ & $\begin{array}{l}\text { Preparar o corpo docente } \\
\text { trabalhara inter, multi } \\
\text { transdisciplinares, e para a } \\
\text { incorporação da sustentabilidade no } \\
\text { processo de ensino e aprendizagem. } \\
\text { Promover a docência comprometida } \\
\text { e a educação transformadora }\end{array}$ \\
\hline 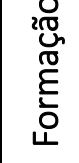 & Pesquisa & $\begin{array}{l}\text { Desenvolver tecnologias limpas, } \\
\text { buscar soluções para os problemas } \\
\text { econômicos, ambientais e sociais da }\end{array}$ \\
\hline
\end{tabular}




\begin{tabular}{|l|l|l|}
\hline \multirow{2}{*}{} & $\begin{array}{l}\text { atualidade. Formar redes de pesquisa } \\
\text { envolvendo IES }{ }^{117}, \text { órgãos públicos e } \\
\text { empresas para o atendimento das } \\
\text { demandas ambientais e sociais }\end{array}$ \\
\cline { 2 - 3 } & $\begin{array}{l}\text { Promover a integração com a } \\
\text { sociedade, promovendo a melhoria } \\
\text { da qualidade de vida e as condições } \\
\text { ambientais. Implementar programas } \\
\text { de extensão no âmbito local, regional, } \\
\text { nacional e internacional }\end{array}$ \\
\hline
\end{tabular}

Tabela 8- diretrizes para o planejamento físico de um campus sustentável. (Fonte: Oliveira, 2009, p. 77).

Em síntese, para uma universidade ser considerada sustentável é necessário a aplicação das seguintes diretrizes já apresentadas:

117 Instituição de Ensino Superior. 


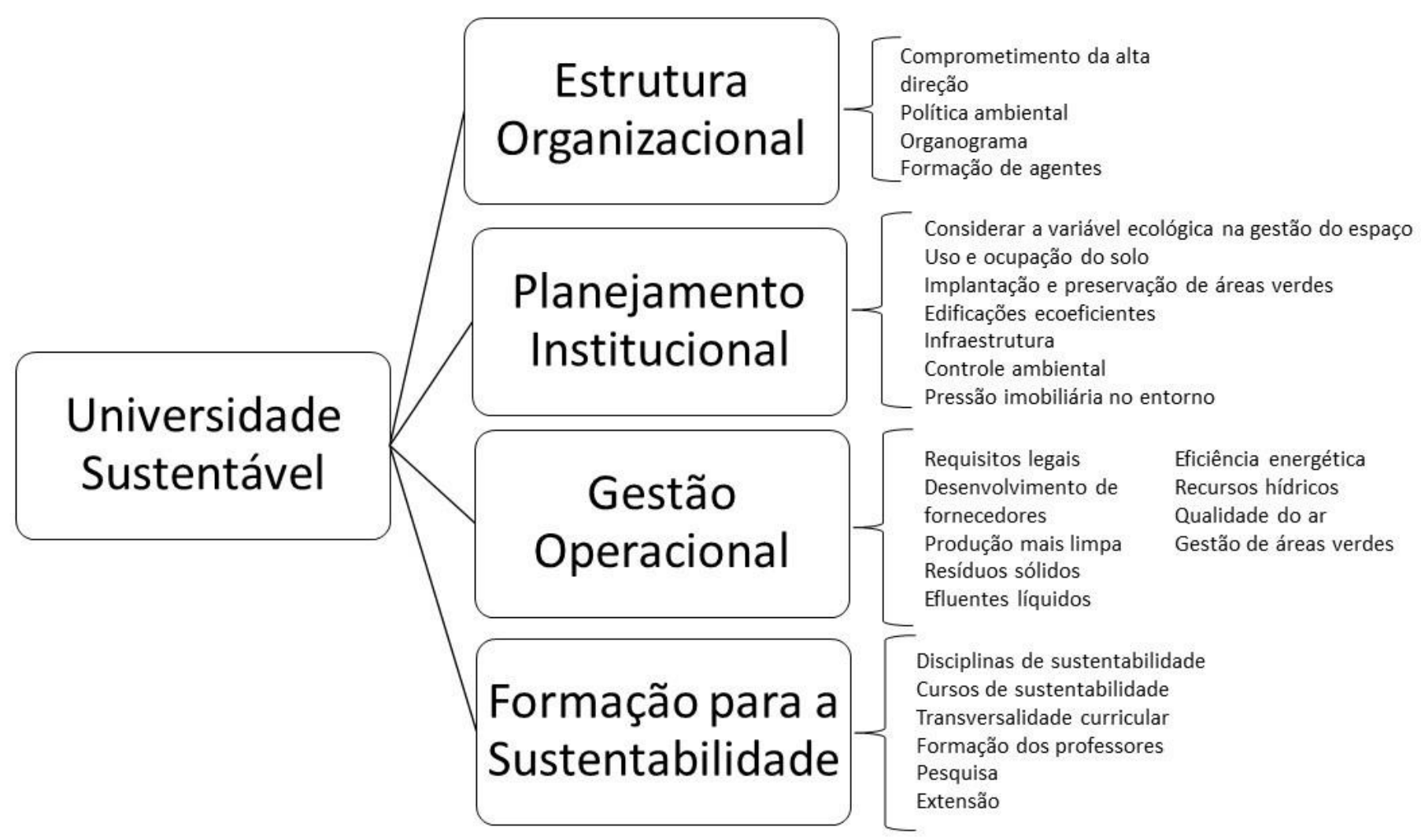

Imagem 65- Síntese das diretrizes apresentadas no capítulo.

(Fonte: adaptado de Oliveira, 2009, p. 77). 
5.2. Métodos de avaliação e compromissos para a criação de Campi Sustentáveis

Certificações são avaliações feitas sobre edifícios para quantificar o quão sustentável é um projeto de acordo com determinados critérios de desempenho. Segundo Gonçalves e Duarte (2006), a ideia de avaliar os critérios no projeto pode ser feita através de simulação computacional, e o método de avaliação geralmente irá resultar em um sistema de pontuação e peso. Existem alguns indicadores de sustentabilidade no mundo que não chegam a ser obrigatórios, mas despertam o interesse de empresas por uma imagem 'verde'. Dois métodos de avaliação aplicados amplamente são o sistema BREEAM ${ }^{118}$, Building Research Establishment Environmental Assessment Method, e o sistema LEED, Leadership in Energy and Environmental Design.

O BREEAM é um método inglês de avaliação de projetos que engloba não só o projeto em si, mas também os processos envolvidos. Aplicado em mais de 77 países, avalia diversas questões relacionada

118 BREEAM significa Método de Avaliação Ambiental do Building Research Establishment (BRE), instituição inglesa responsável pela criação do selo. a sustentabilidade como energia, inovação, uso do solo, materiais, gerenciamento, poluição, transporte, resíduos e água. Sua avaliação possui os níveis: Aprovado, Bom, Muito Bom, Excelente e Excepcional. A criação de cenários de avaliação e objetivos para os projetos pelo BREEAM tem contribuído de forma significativa para a questão da sustentabilidade.

"O BREEAM chega ao Brasil sob o esquema de certificação internacional BESPOKE - um sistema personalizado e adaptado que incorpora as normas e regulamentos locais. O BESPOKE foi desenvolvido para projetos internacionais e cobre diversos programas: residenciais, comerciais, escritórios, industriais, entre outros"119

Category issues and aims
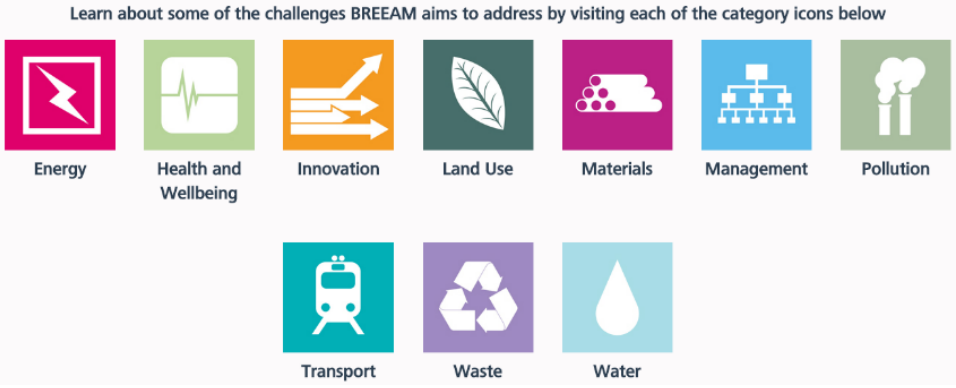

Figura 66- Categorias avaliadas pelo BREEAM: Energia, Saúde e BemEstar, Inovação, Uso do Terreno, Materiais, Administração, Poluição, Transporte, Desperdício e Água.

(Fonte: http://www.breeam.com/, acessado dia 09 de setembro de 2016, as $11: 21 \mathrm{hrs})$

119 http://www.inovatechengenharia.com.br/breeam/ (acessado dia 09 de setembro de 2016, as 11:26 hrs). 
Já o sistema LEED foi desenvolvido pelo United States Green Building Council, é um sistema de certificação e orientação ambiental de edificações. A avaliação é dividia em grupos para obtenção de pontuações: sustentabilidade da localização, eficiência no uso de água, eficiência energética e cuidados com as emissões na atmosfera, otimização dos materiais e recursos naturais a serem utilizados na construção e operação da edificação, qualidade ambiental no interior da edificação, uso de novas e inovadoras tecnologias que melhorem o desempenho do edifício e edificações que se preocupam com questões ambientais regionais.

No Brasil foram adaptadas as certificações para as condições e realidades brasileiras e a certificação é feita pelo Green Building Council Brasil. O projeto deve ser registrado junto ao conselho e então a certificação será válida com a confirmação dos pré-requisitos estabelecidos no registro. O selo LEED Schools regulamenta o projeto de escolas e é a única certificação voltada diretamente para ambientes educacionais do sistema.

Marcomin e Silva (2009) analisaram vinte e duas universidades brasileiras em onze Estados e revelaram que as iniciativas em relação ao ensino ambiental se devem mais a grupos de docentes e pesquisadores do que à existência de políticas institucionais e ao incentivo dos órgãos gestores. Os esforços para a universidade se tornarem ambientalmente sustentável deve ser feito nos três pilares tradicionais: ensino, pesquisa e extensão.

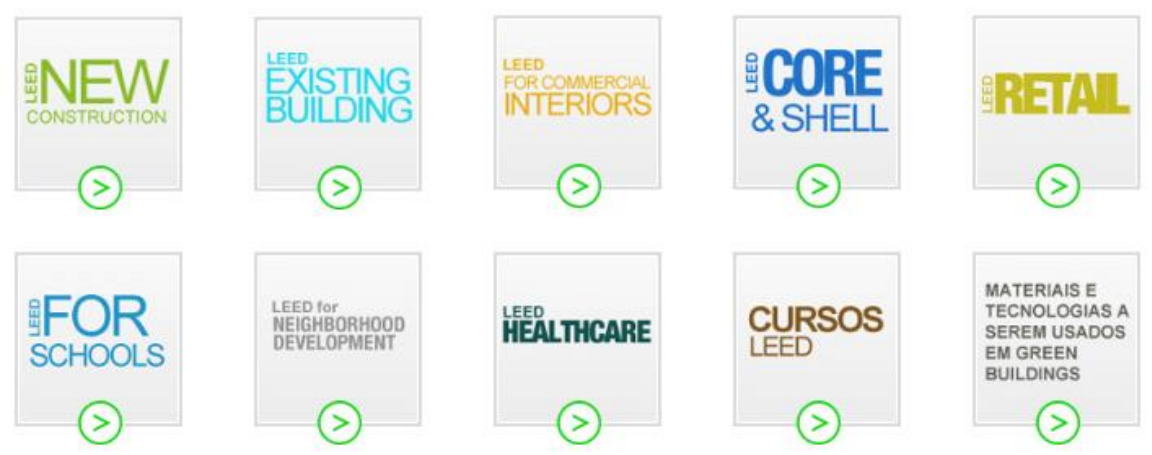

Figura 67- As tipologias de certificação aplicadas pelo Green Building Council Brasil.

(Fonte: http://www.gbcbrasil.org.br/sobre-certificado.php, acessado dia 09 de setembro de 2016, as 11:21 hrs).

Os esforços relacionados à ambientalização da universidade devem ser considerados no plano de desenvolvimento institucional que se reflete em todos os principais planos da instituição. Um fator fundamental para a realização dos planos é o monitoramento dos resultados, ou seja, a avaliação da realização efetiva dos objetivos e metas definidos nos diversos planos (Marcomin e Silva, 2009). 
Dentre os sistemas de avaliação ambiental é possível citar também: Haute Qualité Environnementale, $\mathrm{HQE}^{120}$, que é um sistema francês para avaliação de edificações verdes. O sistema é divido em critérios externos e internos. Os critérios externos são: a relação entre o edifício e o meio ambiente ao redor, a escolha dos métodos construtivos e materiais, minimização de consumo de energia, água, geração de resíduos e necessidade de manutenção. Internamente, o edifício deve: ter um controle de umidade, temperatura e acústica, ser atrativo visualmente, controlar a emissão de poluição, estar sempre limpo, ter controle de qualidade do ar e água.

A Suécia possui uma iniciativa chamada EcoEffect ${ }^{121}$, cujo objetivo é descrever quantitativamente descrever o impacto ambiental e de saúde de imóveis e do ambiente construído e, também, fornece uma base para comparação e tomada de decisão que pode levar a um impacto ambiental reduzido. O método analisa o planejamento, concepção e gestão do ambiente construído. Um software EcoEffect foi desenvolvido no âmbito de projeto, que, juntamente com uma folha de entrada de dados constitui uma

\footnotetext{
${ }^{120} \mathrm{http}: / /$ www.behqe.com/fr (acessado dia 08 de setembro de 2016, as 21:25 hrs).

$121 \mathrm{http}: / /$ www.ecoeffect.se/ (acessado dia 08 de setembro de 2016, as 21:43 hrs).
}

ferramenta para que seja utilizado o método EcoEffect na prática. Os resultados são basicamente comparativos entre o edifício em questão e os outros já avaliados.

Na Noruega existe o Ecoprofile ${ }^{122}$ que classifica os edifícios em 3 classes distintas: 1 para baixo impacto ambiental, 2 para médio impacto ambiental e 3 para alto impacto ambiental. O método é divido em 3 grandes categorias com subdivisões. A categoria 'ambiente externo' avalia poluentes que são direcionados para o ar, para a água, para o solo, gerenciamento do consumo de água, as áreas externas da edificação e questões relativas ao transporte, como por exemplo se é possível chegar no edifício de bicicleta e se é possível deixa-la em local seguro. A divisão de recursos avalia as formas de consumo de água, energia (o quanto consome e com qual finalidade a energia está sendo consumida), o uso do solo e a utilização de materiais na construção e manutenção do edifício. A terceira grande categoria é relativa a climatização interna do edifício sendo avaliados a condição térmica do edifício com auxílio de softwares de simulação, a emissão de calor das partes do edifício,

122 http://www.ires.nus.edu.sg/davoslist/13.pdf (acessado dia 08 de setembro de 2016, as 22:14 hrs). 
reflexão de raios ultravioleta, nível de ergonomia dos escritórios e os fatores causados por problemas nos sistemas de agua, ventilação e resíduos.

Nos Estados Unidos as universidades possuem um green office voltado aos problemas sustentáveis desde o desenvolvimento de simples ações até a construção de novos prédios de acordo com o LEED.

Há um ranking internacional que avalia os campi universitários a partir de documentação enviada online e sem visita técnica às instalações universitárias e sem analisar o histórico da universidade que a fez pleitear uma posição como campus universitário: o Greenmetric World University Ranking ${ }^{123}$. Esse ranking analisa universidades a partir de filosofias baseadas no meio ambiente e na economia, determinando, após considerar e avaliar uma série de fatores e iniciativas tais como o tamanho da universidade, o zoneamento, áreas verdes, consumo de energia e pegada de carbono, transporte, uso de água, gestão de resíduos, infraestrutura, educação e políticas públicas, se a universidade pode ou não ser considerada uma universidade verde. A Universidade Federal de Lavras, localizada no Estado de Minas Gerais, foi avaliada como a universidade brasileira mais sustentável e a segunda na América Latina. A universidade afirma, através de documentos publicados, que ganhou esta posição depois de deixar o posicionamento teórico e realmente começar a colocar em prática ações sustentáveis que respeitem os princípios do desenvolvimento sustentável e da conservação do meio ambiente como a gestão da recolha de química e reciclagem de resíduos, tratamento de esgoto e a preservação dos rios.

Os itens avaliados por esse ranking acompanham as diretrizes aplicadas em campus sustentável porém é um processo de análise burocrática e sem visita de representantes para compreensão dos processos e métodos do quais as universidades tomaram para chegar nas posições em que se encontram; não sendo, então, um método realmente efetivo de avaliação.

No Brasil a UFSCAR, Universidade Federal de São Carlos, optou por um desenvolvimento de campus sustentável em Sorocaba, a Unicamp, Universidade Estadual de Campinas, está implantando um novo plano diretor com premissas sustentáveis e a Universidade de Passo Fundo está implementando o Sistema de Gestão Ambiental no

${ }^{123}$ http://greenmetric.ui.ac.id/ (acessado dia 02 de maio, as 14: 37 hrs). 
campus. O projeto da Universidade Federal do Amazonas - campus Manaus, de 1973, já contava com soluções passivas de conforto térmico, coberturas duplas independentes, dentre outras iniciativas. O campus novo da UTFPR, Universidade Tecnológica Federal do Paraná, em Curitiba é chamado de ecoville e está sendo implantado estudos de propostas de projeto com estratégias sustentáveis.

A certificação de empresas sustentáveis ocorre por meio da ISO ${ }^{124} 14001$ que foi resultado da conferência RIO-92. A ISO 14001 especifica um framework de controle para um sistema de gerenciamento ambiental através do qual qualquer empresa pode ser certificada por um terceiro.

$$
\text { A implantação da ISO } 14001 \text { é baseada no método }
$$
planejamento-execução-verificação-atuação. O planejamento envolve a identificação de todos os elementos do processo de produção que possam interagir com o meio-ambiente visando elaborar os objetivos da empresa em direção à implantação do sistema de gerenciamento ambiental.
$\mathrm{Na}$ fase de execução a empresa implementa os processos e procedimentos que são descritos em um único procedimento documentado que é enviado ao controle de operações, neste momento também é importante implantar a comunicação entre todos os setores da empresa já que todos os funcionários devem estar envolvidos no processo (Martin, 1998).

Para que seja executada a parte de verificação, o desempenho da empresa é monitorado e medido periodicamente para garantir que os objetivos estão sendo alcançados. Auditorias internas também são realizadas em intervalos planejados para avaliar se o sistema de gerenciamento sustentável está atingindo as expectativas do usuário e se os processos e procedimentos estão sendo adequadamente mantidos e monitorados.

Após a fase de verificação a fase de atuação irá revisar os objetivos e verificar se estão sendo atingidos, além de avaliar as implicações legais para expansão do sistema de gerenciamento sustentável.

\footnotetext{
${ }^{124}$ ISO significa International Organization for Standardization (Organização Internacional de Normalização).
} 


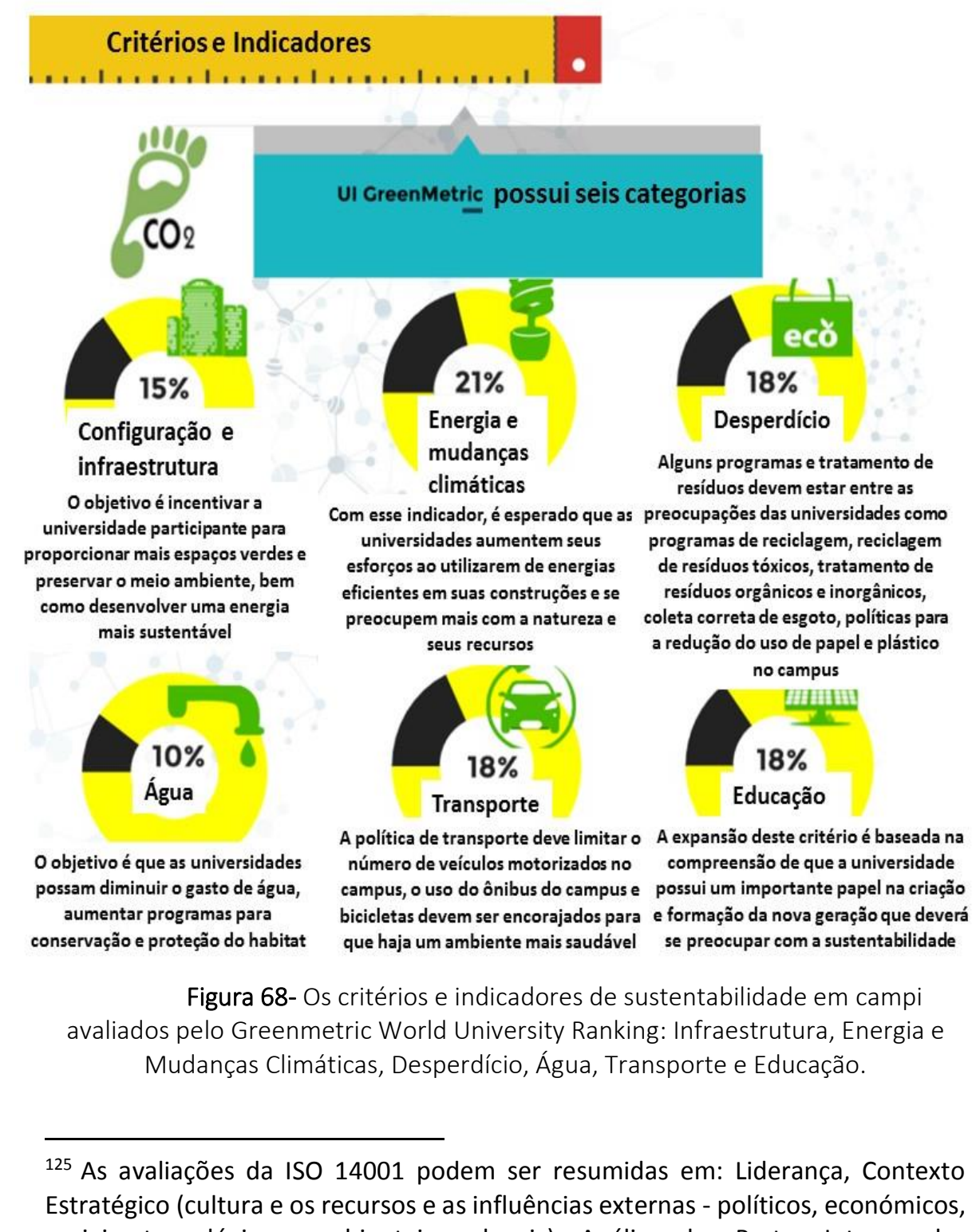

sociais, tecnológicos, ambientais e legais), Análise das Partes Interessadas
(Fonte: adaptado de http://greenmetric.ui.ac.id/wp-

content/uploads/2015/07/Criterialndicators1.png, acessado dia 09 de setembro de 2016, as 11:21 hrs).

Ao final do processo, a certificação ISO 14001 encoraja a empresa a continuar expandindo o sistema de gerenciamento para todos os departamentos da empresa. Esta expansão ocorre basicamente de três formas: expandindo o número de departa mentos cobertos pelo sistema de gerenciamento; aumentando o número de processos, procedimentos, recursos e atividades englobados pelo sistema de gerenciamento; e uma melhoria na organização estrutural do framework do sistema, bem como a acumulação de know-how em lidar com questões econômicoambientais $^{125}$ (Martin, 1998).

A ISO 14001 também é um instrumento avaliados de campi sustentáveis já que a norma internacional ISO 14001 é o maior elogio para um Sistema de Gestão Ambiental e é reconhecido internacionalmente como um símbolo para as melhores práticas que visam minimizar o impacto ambiental.

(estudantes, comunidades locais, reguladores, etc.), Riscos e Oportunidades, Análise do Ciclo de Vida. 
Os benefícios dessa certificação para campus universitário são os mais próximos das diretrizes a serem aplicadas em campi sustentáveis já que englobam a economia de energia, redução de consumos, reciclagem de materiais e resíduos e a preocupação com a redução de poluentes e as iniciativas tomadas para tal questão.

Os programas Advancement of Sustainability in Higher Education 126 e Higher Education Associations Sustainability Consortium ${ }^{127}$ são Organizações sem Fins Lucrativos que visam orientar a criação de greencampi capacitando professores, administradores, funcionários e alunos de uma Instituição de Ensino Superior que busca alcançar metas para a aplicação de práticas sustentáveis em campi.

Outras formas de compromissos e iniciativas para o desenvolvimento, adaptação, discussão e/ou construção de campi sustentáveis ocorreram em distintos países através de conferências, programas, congressos e outros tipos de documentos como: (a) Associação Universitária para o Meio Ambiente (Bélgica, 1979 a 2005) que reunia universidades interessadas em discutir problemas

\footnotetext{
${ }^{126}$ http://www.aashe.org/about (acessado dia 16 de fevereiro de 2017, as 19:52 hrs).
}

ambientais; (b) Conferência dos Reitores da Europa e a criação do Programa COPERNICUS (Reino Unido, 1988) que lançou os dez princípios da Carta das Universidades para o Desenvolvimento Sustentável e o compromisso das universidades europeias com a educação e a pesquisa voltadas para o desenvolvimento sustentável; (c) Declaração de Talloires (França, 1990) que buscava construir lideranças voltadas para a sustentabilidade em Instituições de Ensino Superior; (d) Conferência sobre Ações da Universidade para o Desenvolvimento Sustentável e a Declaração de Halifax (Canadá, 1991) que reuniu trinta e três universidades preocupadas com a depredação do meio ambiente e o crescimento da pobreza; (e) constituição da Organização Internacional de Universidades pelo Desenvolvimento Sustentável e Meio Ambiente (Costa Rica, 1995) cujo objetivo é a realização de pesquisas e o desenvolvimento de programas voltados para o desenvolvimento sustentável; (f) Declaração de Haga (Estocolmo, 2000 e 2002) que discutiu a adoção da Agenda 21 na educação para o desenvolvimento sustentável

${ }^{127}$ http://heasc.aashe.org/content/about-heasc/ (acessado dia 16 de fevereiro de 2017, as 19:52 hrs). 
através de pesquisas com temáticas ambientais e da criação de uma rede que compartilhe essas experiências (Tauchen e Brandli, 2006).

\subsection{Exemplos de Campi Sustentáveis}

Tauchen e Brandli (2006) apresentam em seus trabalhos as universidades que seguem princípios apresentados neste capítulo para uma universidade sustentável, somados com a norma ISO 14001 (Planejamento, Execução, Verificação e Ação).

As universidades analisadas somam quarenta e duas espalhadas pelo Estados Unidos (pioneiros na inserção da sustentabilidade na gestão dos campi), Alemanha, América Latina, Reino Unido (líder europeu dentro da área de universidades preocupadas com o desenvolvimento sustentável), Nova Zelândia, Canadá, Portugal, Espanha e França, essa escolha deu-se por serem instituições de locais distintos e com ações voltadas para a sustentabilidade.

\begin{tabular}{|c|l|}
\hline \multicolumn{1}{|c|}{ País } & \multicolumn{1}{|c|}{ Universidade } \\
\hline Alemanha & -Universidade de Zittau Görlitz \\
\hline & $\begin{array}{l}\text {-Universidade Nacional } \\
\text { Autônoma do México }\end{array}$ \\
\hline
\end{tabular}

\begin{tabular}{|c|c|}
\hline América Latina & 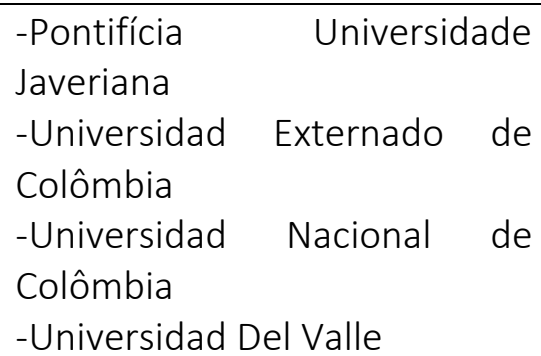 \\
\hline Canadá & -British University \\
\hline Espanha & $\begin{array}{l}\text {-Universidade Autônoma de } \\
\text { Barcelona } \\
\text {-Universidade Autônoma de } \\
\text { Madrid } \\
\text {-Universidade de Granada }\end{array}$ \\
\hline Estados Unidos & $\begin{array}{l}\text {-Emory University } \\
\text {-Vermont University } \\
\text {-Burlington University } \\
\text {-Michigan University } \\
\text {-University of South Carolina } \\
\text {-University of Missouri-Roll } \\
\text {-Harvard University } \\
\text {-Carnegie Mellon University } \\
\text {-Louisville University } \\
\text {-Middlebury College }\end{array}$ \\
\hline França & -Universidade de Boudeaux \\
\hline
\end{tabular}




\begin{tabular}{|c|l|}
\hline Nova Zelândia & -Universidade de Auckland \\
\hline \multirow{3}{*}{ Portugal } & -Universidade do Algarve \\
& -Universidade do Aveiro \\
& -Universidade Técnica de \\
& Lisboa \\
& -Universidade de Nova Lisboa \\
\hline & -Bishop Burton College \\
& -Blackburn College \\
& -Cornwall College \\
& -Huddersfield New College \\
& -Southgate College \\
& -Enfield College \\
& -Capel Manor Horticultural \\
& College \\
& -Envirenmental Centre \\
& -South West Association for \\
& Education and Training \\
& -St. Helens College \\
& -Walford e North Shopshire \\
& College \\
& -Walsall College of Arts and \\
& Technology \\
& -Wigan e Leigh College Wigan \\
\hline
\end{tabular}

Tabela 9- universidades pesquisadas.

(Fonte: adaptado de Tauchen e Brandli (2006)).

As ações que mais se assemelharam entre os campi foram:

(a) Gestão e reciclagem de resíduos (22\%); (b) Controle no consumo e reuso de água (22\%); (c) Educação ambiental
(19\%); (d) Auditoria ambiental (16\%); (e) Diagnóstico dos impactos ambientais (16\%).

Segundo Fouto (2002, p. 07) as universidades europeias que buscam o desenvolvimento sustentável baseiam-se no COPERNICUS, Cooperation Program for Environmental Research in Nature and Industry through Coordinated University Studie, cujo objetivo é "envolver as universidades na partilha de conhecimento e expertise na área do desenvolvimento sustentável e de encorajá-las a estabelecer parcerias com a indústria e gestão".

Universidade Autônoma de Madrid, UAM, possui um projeto chamado ECOCAMPUS. Em 1997 foi formalizado o compromisso da universidade com a Agenda 21 visando melhorias na situação ambiental do campus e sensibilizando a comunidade universitária. Com objetivo de unir as iniciativas de gestão e educação as quatro linhas estratégicas de ação são (Álamo e Massambani, 2010): (a) Gestão Ambiental - projetos de consumo de água, transporte e mobilidade, edificações, ambientalização de interiores, paisagismo, gestão de resíduos e eficiência energética; (b) Envolvimento da Comunidade Universitária - ações voltadas à promoção da educação ambiental, participação e ambientalização curricular; (c) Pesquisa 
para a Sustentabilidade - desenvolvimentos de trabalhos de conclusão de curso relacionados à temática sustentável potencializando a relação com grupos de pesquisa nesta área; (d) Envolvimento da Sociedade - relações entre estudantes da UAM e outras instituições universitárias, além da colaboração com associações de âmbito autônomo e nacional.

Já o documento Organization for Economic Co-Operation and Development, OECD, elaborado em 2007, analisou Instituições de Ensino Superior internacionais em relação aos seus programas sustentáveis. Os principais requisitos analisados foram: uso de recursos de forma eficiente, relação com novas formas de economia, conservação e aprimoramento do meio ambiente, atração e retenção de profissionais e estudantes de alta qualidade, disponibilidade de uma experiência de estudo de alta qualidade, promoção de aprendizado vitalício, favorecimento para programas relacionados à governança e gerenciamento responsável, antecipação de mercados futuros para estudantes formados, adequação a outras políticas externas ao campus, absorção de valores relacionados ao uso da propriedade de forma sustentável, excelência em pesquisa e ensino, compartilhamento de recursos da universidade com a população, eficiência econômica, compartilhamento de programas adotados na universidade e grau de modernização no gerenciamento de risco (OECD, 2007).

As universidades melhores analisadas foram:

Universidad Politecnica de Catalunya, Espanha, uma das pioneiras em redução de geração de resíduos. A universidade recrutou um time ambiental para que a comunidade acadêmica fosse conscientizada sobre a questão da sustentabilidade.

Os recursos provenientes da economia gerada com a conscientização foram reinvestidos na universidade criando um centro interdisciplinar de tecnologia, inovação e educação para sustentabilidade, e também utilizado em projetos sustentáveis (OECD, 2007).

Institute of Technology Sonora, México, possui um programa de cultura ambiental, cujo objetivo é a redução do consumo de energia, papel e outros recursos não-renováveis. Este programa utiliza a metodologia de Balanced Socrecard e pratica os três R's do gerenciamento de resíduos: redução, reuso e reciclagem. Existem medidas para verificar a diminuição de resíduos e também uma preocupação com o solo para preservar os lençóis freáticos. 
O resultado foi a conversão das áreas do campus em áreas verdes, foi criado o Instituto de Desenvolvimento que abriga projetos de desenvolvimento humano, social e empresarial. Existe também um programa de doutorado em planejamento estratégico com doze projetos práticos de desenvolvimento sustentável para a comunidade (OECD, 2007).

Autonomous University of San Luis Potosi, México, criou um programa que faz a conexão entre poluição e problemas de saúde através de pesquisas interdisciplinares para auxiliar comunidades locais (OECD, 2007).

Turku University of Applied Sciences, Finlândia, possui uma estratégia de responsabilidade social corporativa que entrega relatórios sistematicamente aos acionistas e também ao público em geral. Os relatórios são muito completos sendo que o primeiro gerado ganhou um prêmio de melhor relatório público.

Para implantação do sistema, a instituição teve que abrir sua contabilidade aos acionistas de uma forma muito transparente e simples de ser analisada de forma que os programas pudessem ser implementados e os resultados facilmente reconhecidos. Existe inclusive uma graduação em Desenvolvimento Sustentável (OECD, 2007).

Oberlin College, Estados Unidos, a instituição possui um curso de economia ambiental, dedicado a utilização de capital natural. Como exemplo é possível citar o uso de $60 \%$ das fontes de energia da própria instituição fornecida a partir de fontes verdes e, principalmente, de fornecedora local. Estas decisões compensam 1/4 das emissões de carbono da empresa (OECD, 2007).

Portland State University, Estados Unidos, o transporte e estacionamento da universidade apresentou uma alternativa eficaz para as pessoas que iam de carro: sistemas de carona e bicicletas são subsidiados, além do custo de estacionamento aumentar gradativamente para quem vai com seu carro sempre. Os fundos arrecadados com esta política são utilizados para financiar o transporte público da universidade (OECD, 2007).

University of Copenhagen, Dinamarca, essa universidade mantém três jardins botânicos na Dinamarca que contém importantes exemplares de plantas raras e geram diversos trabalhos científicos (OECD, 2007). 
University of the Sunshine Coast, Austrália, mantém parte da Frasier Island como um local de preservação ambiental, pesquisa científica e atividades educacionais. O ecossistema da ilha é complexo com dunas, lagos e florestas subtropicais cujo crescimento acontece exclusivamente na areia sendo um interessante objeto de estudo (OECD, 2007).

Chalmers University of Technology, Suécia, a preocupação principal nesta universidade são programas para garantir qualidade de vida aos funcionários. São oferecidas atividades esportivas, auxílio médico e conselhos sobre ergonomia e postura.

Esta universidade também oferece aulas aos alunos ingressantes sobre desenvolvimento sustentável, além disso os programas de mestrado em engenharia e arquitetura foram obrigados a incluir a disciplina em suas grades curriculares, da melhor maneira para cada curso (OECD, 2007).

University of Plymouth, Inglaterra, possui uma estratégia de desenvolvimento e empregabilidade para todos os graduados. O programa Skills Plus, por exemplo, prepara os graduandos para ser cidadãos e para assumir cargos promovendo a sustentabilidade social (OECD, 2007).
Hosei University, Japão, possui um programa educacional que promove o aprendizado por toda a vida com diferentes cursos engajados diretamente com as comunidades locais em questões importantes para eles. Essa universidade também possui uma política de aquisição de materiais verdes como papel reciclado e eletrônicos com certificação de baixo consumo (OECD, 2007).

University of British Columbia, Canadá, participou de um projeto que fez com que a universidade toda economizasse $20 \%$ de energia: o ECOtrek foi o maior projeto deste nível implantado no Canadá e terminou em março de 2006. Além da energia, o projeto promove a economia de $30 \%$ do consumo de água e diminui a emissão de CO2 em 15.000 toneladas (OECD, 2007).

Algumas das modificações nos edifícios englobam um sistema de ventilação inteligente, aparelhos para medição de consumo e automação, existe um sistema de aproveitamento de água feito em um estacionamento com piso permeável que direciona a água para uma camada de pedras que permite o seu escoamento gradual para o solo, este sistema foi utilizado como modelo para cidades nos Estado Unidos. Juntamente com este programa foi implantando 
também o programa RENEW, que revitaliza os prédios antes de necessitarem de restauro.

Ferre-Ballas et al. (apud Oliveira, 2009, p. 41) analisam universidades dos Estados Unidos, Japão, Suécia, Espanha e Índia a partir de ações sustentáveis, o resultado foi a apresentação dos principais aspectos de uma universidade sustentável,

\begin{abstract}
"as principais dimensões de uma estratégia de transformação e como comparar essas estratégias no nível internacional; como reconhecer o potencial de mudanças; e quais são os principais obstáculos e condutores dessa transformação".
\end{abstract}

Os levantamentos realizados pelos autores foram: educação transformadora (...); a inter e transdisciplinaridade na pesquisa; a busca de resolução dos problemas sociais através do ensino e da pesquisa utilizando de ensino prático; redes de conhecimentos (...) para partilhar recursos de forma eficiente e adequada; e a liderança e visão que promovam a (...) mudança de pensar a longo prazo (Ferrer-Balas et al., 2008).

O método utilizado pelos autores foi o 'FLA approach' ( $F=$ Framework, $\mathrm{L}=$ Level, $\mathrm{A}=$ Actors) para levar em conta as principais dimensões estruturais utilizadas; foi verificado que é importante modificar a cultura, as estruturas transdisciplinares, a infraestrutura e a tecnologia utilizada pelo campus.

Há também a ISO 14001, um exemplo de importante de universidade da América Latina é a Universidade de Sonora, México, a primeira a receber a norma. Velásquez et al. (2008) afirmam que um campus deve erradicar ou diminuir suas ações negativas, além de auxiliar a mudança para uma sociedade mais sustentável, assim, a Universidade de Sonora segue o modelo apresentado na figura 67.

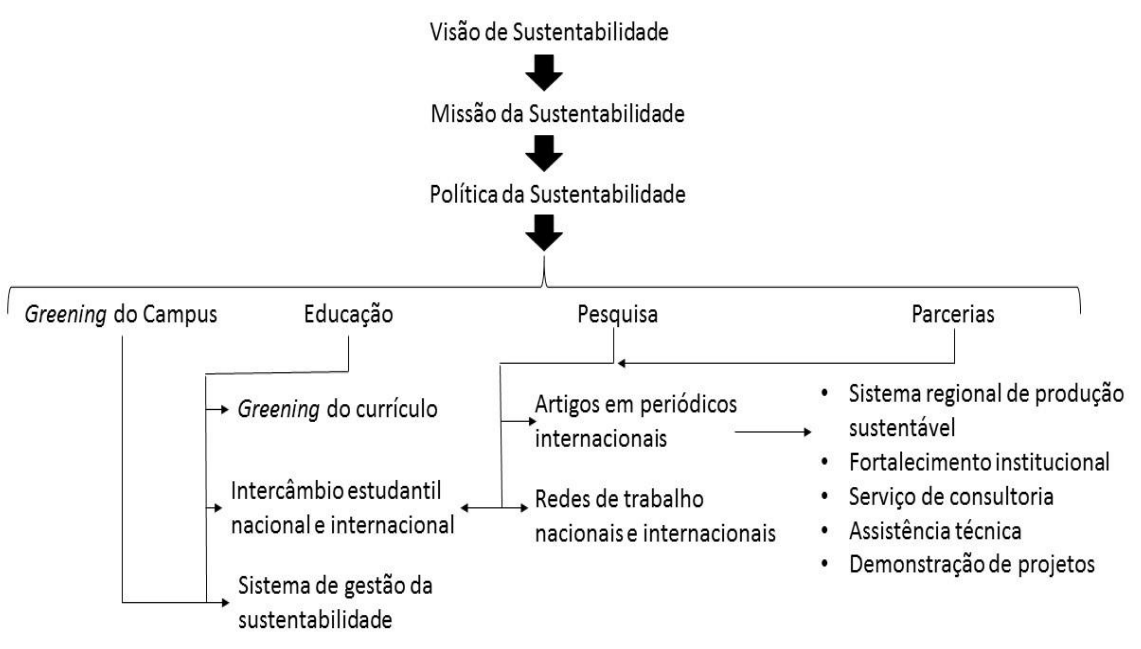

Figura 69- Padrões sustentáveis aplicados na Universidade de Sonora. (Fonte: adaptado de Velásquez et al., 2008, p. 07). 
É importante ressaltar que tanto a Universidade de Sonora quanto as universidades analisadas por Tauchen e Brandli (2006) a fusão entre o ensino, a pesquisa e a gestão ambiental dos campi caminham unidas para levar aos alunos e funcionários uma formação dinâmica e um grande campo de pesquisa, para a universidade essa união de valores garantem uma gestão institucional comprometida com a sustentabilidade.

No Brasil, a Universidade do Vale do Rio dos Sinos, Rio Grande do Sul, foi certificada com a norma ISO 14001, sendo a primeira universidade particular da América Latina a receber essa norma. Como é possível observar em sua página digital ${ }^{128}$, a universidade adotou distintas posturas voltadas para o desenvolvimento sustentável como o reaproveitamento d'água, campanhas de conscientização sobre a economia da energia elétrica, a gestão de resíduos e das áreas verdes, a aplicação da coleta seletiva de sólido, entre outras ações.

Já a Faculdade Horizontina, FAHOR, Rio Grande do Sul, está adotando esses modelos de ações. Tauchen (2008) fala sobre o

\footnotetext{
${ }^{128} \mathrm{http}: / /$ unisinos.br/novocampuspoa/categorias/sustentabilidade/ (acessado dia 08 de setembro de 2016, as 23:01 hrs).
}

programa Eco-FAHOR que alcançou resultados como a construção de uma cisterna com capacidade para 15.000 litros para a captação de águas a ser usada em limpeza e irrigação, gerenciamento de resíduos e energia elétrica, uso de papel reciclado e atividades de reflorestamento. A universidade também estava finalizando o projeto 'Água Limpa' que visava abastecer não só a universidade, mas também a cidade onde está inclusa.

Já a Universidade Federal do Rio Grande do Sul criou em 1999 o Grupo Interdisciplinar de Gestão Ambiental que visava realizar trabalhos de gestão de resíduos e educação ambiental dentro da universidade. Para a realização de ações mais profundas e efetivas foi criada, em 2007, a Coordenadoria de Gestão Ambiental do campus (Campani et al., 2007).

A Universidade Estadual de Londrina criou o Programa de Gestão Ambiental cujo objetivo é a construção de uma comunidade universitária mais sustentável a partir de ações que minimizam resíduos, conservam o meio ambienta, melhoram a qualidade de vida e formam profissionais responsáveis com esses propósitos ${ }^{129}$.

${ }^{129}$ http://www.uel.br (acessado dia 09 de setembro de 2016, as 23:40 hrs). 
A universidade também tem programa de coleta seletiva e reciclagem de resíduos, gerenciamento de resíduos, uso racional da energia elétrica e diminuição do consumo d'água.

A Universidade Federal de Santa Catarina, Florianópolis, criou, em 1996, a Coordenadoria de Gestão Ambiental que visava definir uma política ambiental para o campus englobando o ensino, administração e posturas dentro da universidade. Na universidade há políticas voltadas para a preservação dos sistemas hídricos, gerenciamento dos resíduos secos e químicos, compostagem de resíduos orgânicos e um plano de arborização e manutenção das espécies contidas no Plano Diretor ${ }^{130}$.

Os exemplos citados são importantes pois apresentam as ações aplicadas votadas para a sustentabilidade. A certificação do Sistema de Gestão Ambiental da Norma ISO 14001 prova que ainda é uma avaliação importante e respeitável para campi sustentáveis.

$130 \mathrm{http}: / /$ www.ufsc.br/ (acessado dia 09 de setembro de 2016, as 23:55 hrs). 131 http://www.andifes.org.br/ufla-e-reconhecida-como-exemplo-desustentabilidade (acessado dia 09 de setembro de 2016, as 14:43 hrs).

${ }^{132}$ A UFLA gerencia seus resíduos químicos dos laboratórios e está implantando uma estação própria de tratamento de esgoto, também recupera e protege vegetações da Área de Preservação Permanente e protegem nascente. Distintos
Em outro tipo de processo de avaliação, A Universidade Federal de Lavras, UFLA, foi classificada como a 26ạ colocada no Greenmetric World University Ranking, esta posição representa a segunda melhor colocação da América Latina no ranking. A criação de uma Diretoria de Meio Ambiente, DMA, na universidade proporcionou os meios para a implantação de práticas sustentáveis que se iniciaram com o tratamento de resíduos proveniente dos laboratórios de Química ${ }^{131}$; os resíduos sólidos ${ }^{132}$ são levados para a reciclagem e também, tendo em foco a questão da mobilidade de menor impacto e alternativas, foram instalados diversos bicicletários. Outra iniciativa importante foi a manutenção das Áreas de Preservação Permanente, APP, que ficam dentro da área da universidade com a reconstituição de seu ecossistema natural. A universidade também é autossuficiente com relação ao consumo de água, além de tratar todo o esgoto gerado ${ }^{133}$.

prédios da universidade também coletam a água da chuva, a armazenam e a utilizam para fins como limpeza e em banheiros, além de contarem com pontos de coletas seletivas e gestão de resíduos sólidos.

133 http://www.ufla.br/ascom/2016/05/16/ufla-e-azul-2a-universidade-domundo-com-o-certificado-blue-university-em-reconhecimento-pela-gestao-dasaguas/ (acessado dia 09 de setembro de 2016, as 14:43 hrs). 
A conscientização das pessoas envolvidas com a instituição também é um ponto fundamental. Na UFLA foram realizados diversos cursos para conscientizar os funcionários e técnicos que participam dos processos de tratamento de resíduos. No total foram investidos mais de $R \$ 23$ mi nas diversas iniciativas sustentáveis realizadas de 2009 a $2012^{134}$. Os pontos positivos da implantação do plano ambiental foram o apoio financeiro da instituição, o compromisso dos coordenadores, a participação efetiva dos envolvidos no processo, a participação da comunidade acadêmica e, principalmente, o desenvolvimento de uma consciência dos benefícios coletivos advindos do plano ambiental.

Pela iniciativa inovadora com relação ao tratamento e reutilização da água do campus, a universidade recebeu o selo Blue University que foi concedido anteriormente apenas para a Universidade de Berna na Suíça. Este selo é o reconhecimento, por parte do projeto Blue Planet realizado pela organização Blue Community ${ }^{135}$, no Canadá, para as universidades que seguem seis critérios fundamentais: reconhece a água como um direito humano;

\footnotetext{
${ }^{134}$ http://repositorio.enap.gov.br/bitstream/handle/1/281/Eco\%20Universidade. pdf? sequence=1 (acessado dia 09 de setembro de 2016, as 14:43 hrs).
}

promove o consumo de água por meio de infraestrutura pública e gratuita; a gestão da água é de forma responsável; mantém serviços de tratamento da água para consumo e residuais; cultiva parcerias para defender o direito à água em nível internacional e desenvolve pesquisas sobre a gestão sustentável da água.

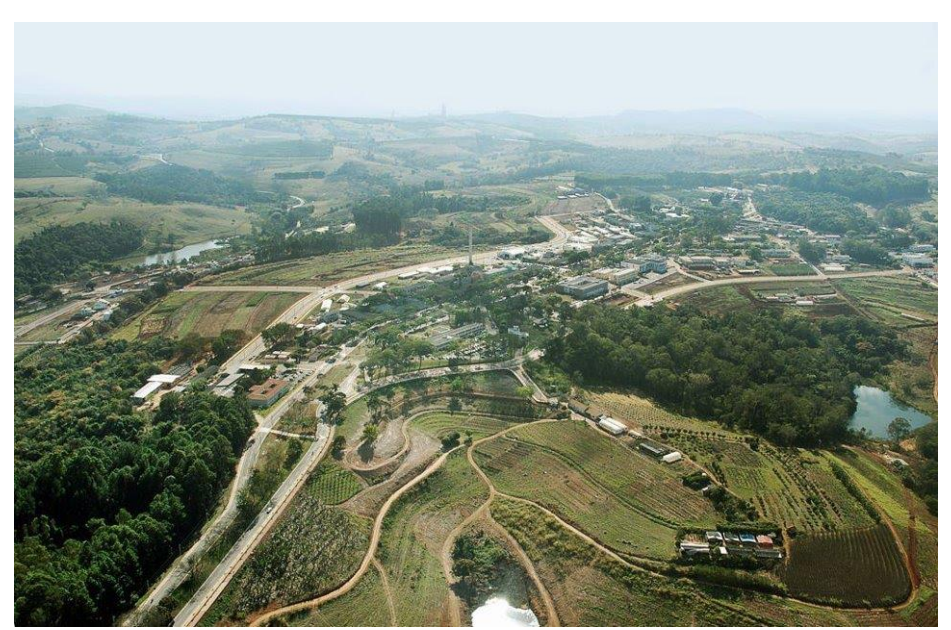

Figura 70- Vista aérea da UFLA, 2012.

(Fonte: http://www.panoramio.com/user/7033587/tags/ufla, acessado dia 09 de setembro de 2016, as 15:31 hrs).

135 http://canadians.org/bluecommunities (acessado dia 09 de setembro de 2016, as 14:43 hrs). 


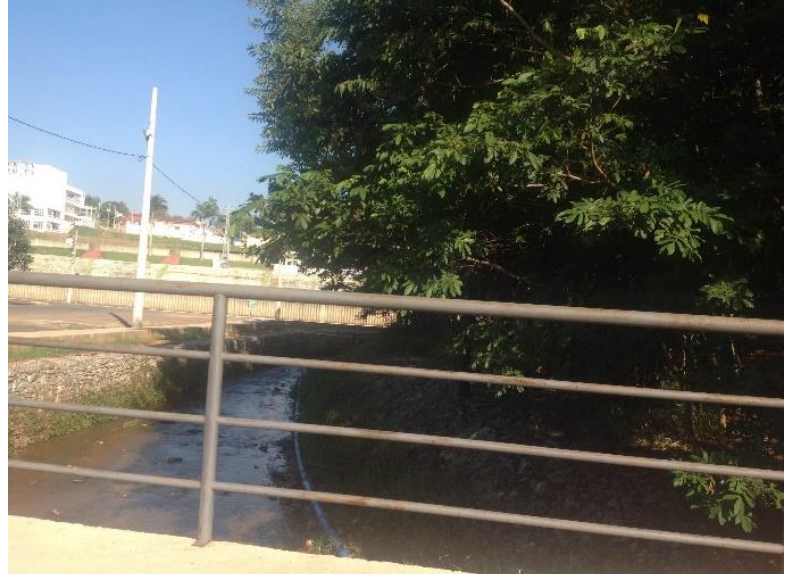

Figura 71- APP e rio dentro do campus da UFLA, 2016. (Fonte: acervo pessoal da autora).

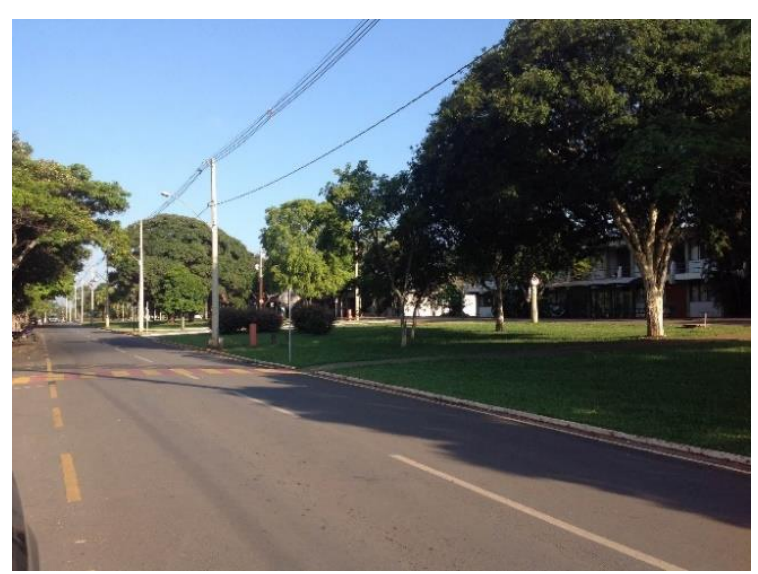

Figura 72- O campus da UFLA, 2016. (Fonte: acervo pessoal da autora).

\footnotetext{
${ }^{136} \mathrm{http}$ ://oglobo.globo.com/rio/bairros/ufrj-quer-tornar-fundao-referenciamundial-em-sustentabilidade-18248112 (acessado dia 16 de fevereiro de 2017, as $17: 30 \mathrm{hrs}$ ).
}

A Universidade Federal do Rio de Janeiro, UFRJ, desde 2015 vem, através do Fundo Verde da UFRJ, tentando transformar as instalações da Ilha do Fundão em referência internacional em questões de economia verde a partir de ações simples nas seguintes áreas: água, energia, mobilidade e tratamento de resíduos.

A universidade já possui resultados positivos após a instalação de painéis solares, carros elétricos verdes que circulam pelo campus com custo gratuito para os alunos e o aumento da quantidade de bicicletários, as próximas iniciativas serão o investimento em pesquisa para melhoria no próprio espaço ${ }^{136}$

Já na Universidade de São Paulo, a agência USP de inovação é um dos principais órgãos a trabalhar com o tema ambiental de forma institucional (Álamo e Massambani, 2010). Em 1993 a agência criou o programa USP Recicla que promove ações visando a redução dos resíduos, conservação do meio ambiente e melhoria da qualidade de vida na USP. O objetivo principal do programa são os resíduos sólidos e suas atividades envolvem toda a comunidade universitária. 
Como mostra a Figura 73, o programa USP Recicla possui uma estrutura de funcionamento organizacional onde existe um comitê gestor composto por funcionários da diretoria da agência USP de Inovação que está diretamente ligado às comissões de cada campus da universidade responsáveis pelo planejamento de atividades e articulação entre o comitê gestor e as unidades. Em cada uma das escolas e institutos existe uma comissão responsável pelo programa composta por pelo menos um docente, três funcionários técnicoadministrativos e dois alunos. O programa está ativo até hoje apresentando soluções para diversas questões ambientais em todas as unidades da USP.

http://abes-dn.org.br/publicacoes/rbciamb/PDFs/1104_artigo_1_artigos133.pdf (acessado dia 24 de fevereiro de 2017, as 17:30 hrs). ${ }^{138}$ http://www.fsp.usp.br/siades/wipis.htm (acessado dia 24 de fevereiro de 2017, as $10: 38 \mathrm{hrs})$.

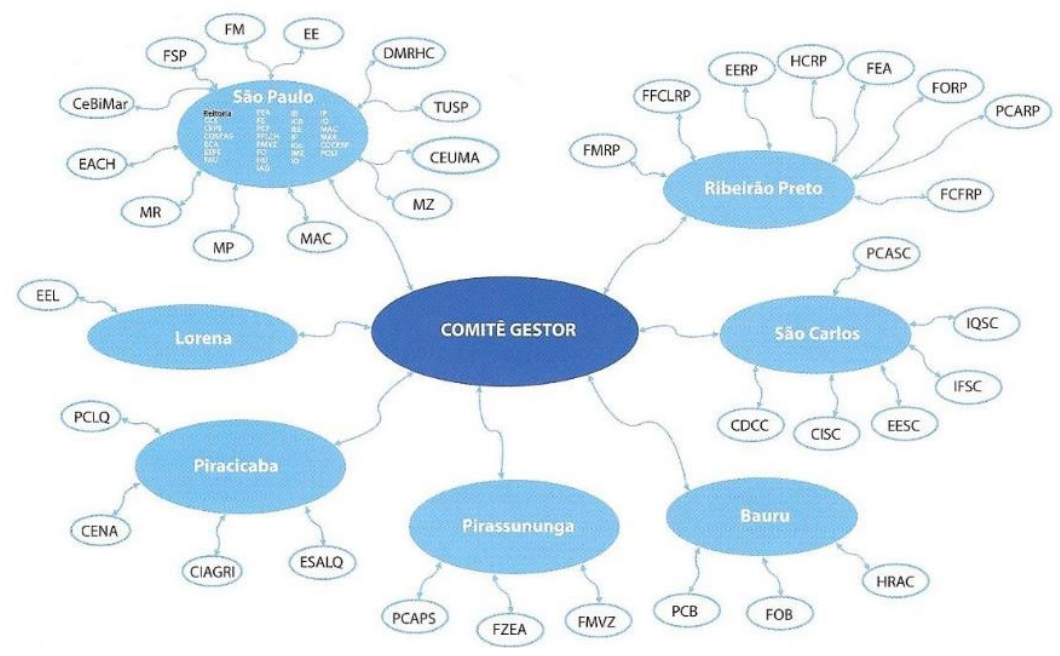

Figura 73 - Organização hierárquica de gestão programa USP Recicla. (Álamo e Massambani, 2010).

Com relação à pesquisa, a Universidade de São Paulo em parceria com outras organizações promove, desde 2006, o Workshop Interdisciplinar de Pesquisa em Indicadores de Sustentabilidade, WIPIS. Até o presente momento foram realizadas quatro edições sendo a primeira em $2006^{137}$, a segunda em $2008^{138}$, a terceira que ocorreu em 2011 ${ }^{139}$, e o IV WIPIS ${ }^{140}$, que ocorreu em 2015 em Concepción no Chile em sua primeira edição fora do país. O Objetivo

139 http://wipis2011.blogspot.com.br/p/sobre-o-wipis.html (acessado dia 16 de fevereiro de 2017, as 18:46 hrs).

$140 \mathrm{http}: / /$ wipis2015.blogspot.com.br/ (acessado dia 24 de fevereiro de 2017, as 10:55 hrs). 
do evento é a promoção da integração de pesquisadores e demais profissionais que trabalham com indicadores de sustentabilidade em nível de ensino, pesquisa e gestão. Este evento impacta diretamente nas ações sustentáveis implantadas na USP por discutir e apresentar indicadores que permitem uma análise mais profunda das atividades e estruturas dos campi e, consequentemente, a elaboração de ações mais efetivas.

Um dos programas criados pela Escola de Engenharia de São Carlos, EESC, em 2011 é chamado de EESC Sustentável ${ }^{141}$. O Objetivo do programa é inserir a sustentabilidade de forma pluridimensional na instituição através da participação de grupos de trabalho que buscam soluções sustentáveis para problemas do Campus de São Carlos. As áreas de atuação do programa podem ser vistas na Figura 74.

http://www.eesc.usp.br/portaleesc/images/docs/PosterEESCSustentavel.pdf (acessado dia 16 de fevereiro de 2017, as 10:36 hrs).

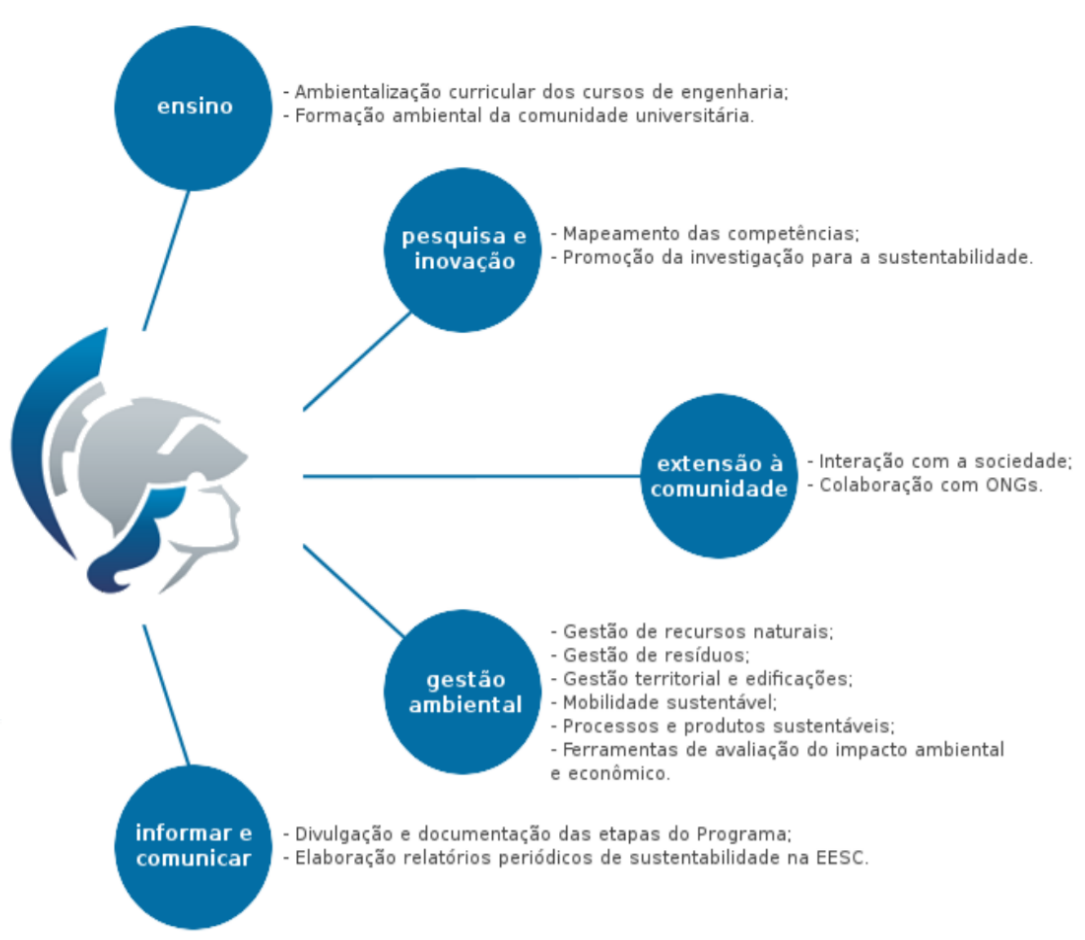

Figura 74 - Campos de atuação EESC Sustentável. (Fonte:

http://www.eesc.usp.br/portaleesc/images/docs/PosterEESCSustentavel.pdf, acessado dia 24 de fevereiro de 2017, as 10:30 hrs).

O programa EESC Sustentável vem melhorando ao longo dos anos e em 2014 teve uma reestruturação com o desenvolvimento de um portal eletrônico e também a estruturação de Sistemas de Gestão 
ambiental para a EESC. Dentre as atividades atuais do grupo é possível citar: proposta de integração da ambientalização nos cursos da EESC, divulgação, discussão e construção de forma coletiva a proposta de integração, aprofundamento do diagnóstico da ambientalização nos cursos da EESC, construção de temas da ambientalização para os cursos da EESC, Implantação de um programa continuado de educação ambiental para os servidores, revisão de indicadores de sustentabilidade baseados em coleta de informações, reavaliação e reestruturação do programa de coleta seletiva, conclusão do Guia de Compras Sustentáveis da EESC (Álamo e Massambani, 2010).

Em agosto de 2012, baseando-se nas atividades atuais do grupo EESC sustentável, foi realizado um Workshop na Escola de Engenharia de São Carlos com objetivo de apresentar e discutir uma proposta de indicadores de sustentabilidade que deveriam ser levados em consideração para avaliação e incremento da sustentabilidade na Universidade de São Paulo como um todo. Neste workshop foram propostos 83 indicadores divididos em 10 áreas diferentes relacionados a todo o tipo de atividade realizada no campus.

O campus Cidade Universitária, apesar de não ser um espaço sustentável, possui algumas iniciativas voltadas para a redução de impactos ambientais e para a promoção de espaços mais saudáveis.

A Coordenadoria do Campus da Capital, Cocesp, realiza campanhas na Cidade Universitária e apresenta soluções sustentáveis para os problemas do campus. Assim como a prefeitura do campus e também SGA, Superintendência de Gestão Ambiental.

A Cocesp dividiu sua atuação sustentável em três eixos ${ }^{142}$ : infraestrutura, qualidade de vida e gestão participativa. Cada eixo é responsável pelos projetos e por obter resultados. Dentre os projetos podemos destacar compostagem de resíduos vegetais, instalação de usina de biodigestão, estação de tratamento de esgoto, produção de biodiesel, mobilidade elétrica, ciclovias e ciclofaixas, iluminação pública por LEDs, Light Emitting Diode, monitoramento animal no campos e eliminação de focos de mosquitos transmissores de

\footnotetext{
$142 \mathrm{http}: / /$ slideplayer.com.br/slide/380326/ (acessado dia 24 de fevereiro de 2017, as 01:44 hrs).
} 
doenças e instalação do ProPESC, Programa de Pesquisa e Experimentação para a Sustentabilidade no Campus.

A prefeitura do campus da capital também possui o programa campus sustentável baseado no Greenmetric com gestão de água, energia, resíduos, mobilidade, baixa geração de carbono, comunicação e gestão de espaços verdes ${ }^{143}$. Em 2013 a USP ocupava - 1440 lugar de 803 universidades do ranking Greenmetric e o objetivo era tornar a USP referência em sustentabilidade no Brasil e no mundo. Para atingir este objetivo a prefeitura do campus da capital participa de todos os projetos do campus e também auxilia na elaboração de soluções sustentáveis.

A SGA, Superintendência de Gestão Ambiental, foi criada em 2012 com objetivo de planejar, implantar, manter e prover a sustentabilidade ambiental ${ }^{144}$ em todos os campi da USP. A SGA é dividida em diversos grupos de trabalho que exploram todas as dimensões da sustentabilidade. Atualmente a SGA cuida também do projeto USP Recicla. Em 2013 a Superintendência de Gestão

\footnotetext{
$143 \mathrm{http}: / /$ slideplayer.com.br/slide/4087021/ (acessado dia 24 de fevereiro de 2017, as 01:50 hrs).

${ }^{144}$ http://www.sga.usp.br/sga/historia/ (acessado dia 24 de fevereiro de 2017, as 01:53 hrs).
}

Ambiental lançou o Programa de Incentivo à Sustentabilidade da USP, que visava apoiar projetos cujos focos fossem a

"conservação dos recursos naturais da Universidade, propiciar um ambiente saudável e ambientalmente seguro nos campi, educar visando à sustentabilidade e construir, de forma participativa, uma Universidade sustentável, como modelo para a sociedade brasileira" 145 .

O Programa também visava conscientizar a comunidade universitária acerca da importância e possibilidades para a conservação dos recursos naturais e incentivar a abordagem das vertentes sustentáveis em projetos para a construção e recuperação de edifícios e outros espaços universitários.
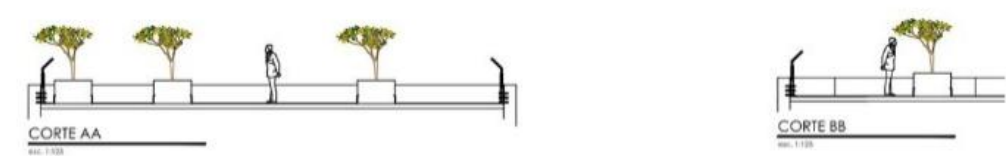

Figura 75- Uma das propostas apresentadas foi o projeto de uma cobertura viva para o edifício 1 da Faculdade de Direito da USP.

Essa área seria um espaço de convivência porém, com os cortes orçamentários, esse projeto não foi viabilizado, sem data. Fonte:

http://www.usp.br/noah/?page_id=1049, acessado dia 16 de fevereiro de 2017, as 12:02 hrs).

145 http://www.usp.br/imprensa/?p=29704 (acessado dia 16 de fevereiro de 2017, as 11:52 hrs). 
Em 2013 houve também uma reunião temática no campus de São Carlos da USP ${ }^{146}$ promovida pelo conselho gestor e com o apoio da Superintendência de Gestão Ambiental. Foram discutidas as diretrizes de ocupação do campus, a política de transporte, estacionamento, ciclovias e mobilidade. As questões foram discutidas com um viés sustentável que auxiliou nas decisões e impactou a vida no campus até hoje.

Outros projetos foram selecionados como o levantamento das disciplinas oferecidas pelos campi USP que abordam a temática da sustentabilidade e se há interdisciplinaridade, após essa ação, desde 2014, é oferecida uma disciplina optativa chamada 'Educomunicação Socioambiental', oferecida na Cidade Universitária, principalmente para alunos da Escola de Comunicação e Artes e da Escola de Artes, Ciências e Humanidades.

Outra disciplina que foi criada a partir do Programa de Incentivo à Sustentabilidade da USP foi a AUP671- Projeto de Infraestrutura Verde, na Faculdade de Arquitetura e Urbanismo em 2014, campus capital, que incentivava os alunos a elaborarem

\footnotetext{
${ }^{146} \mathrm{http}: / /$ www.ccsc.usp.br/conselhogestor_pauta_e_deliberacoes/deliberacoes_r euniao tematica_obras estacionamento.html (acessado dia 16 de fevereiro de 2017, as 17:38hrs).
}

projetos e ideias para a aplicação de Infraestruturas Verdes a serem aplicadas no campus. A partir dos resultados da disciplina, foi realizada uma oficina multidisciplinar para a criação de projetos para edifícios, infraestrutura, drenagem urbana, paisagismo, mobilidade e preservação da natureza local. Os projetos formam Plano de Infraestrutura Verde para a Cidade Universitária que são alternativas viáveis para a construção de espaços mais saudáveis para a comunidade da USP (Pellegrino, 2015; Pellegrino e Castañer, 2014).

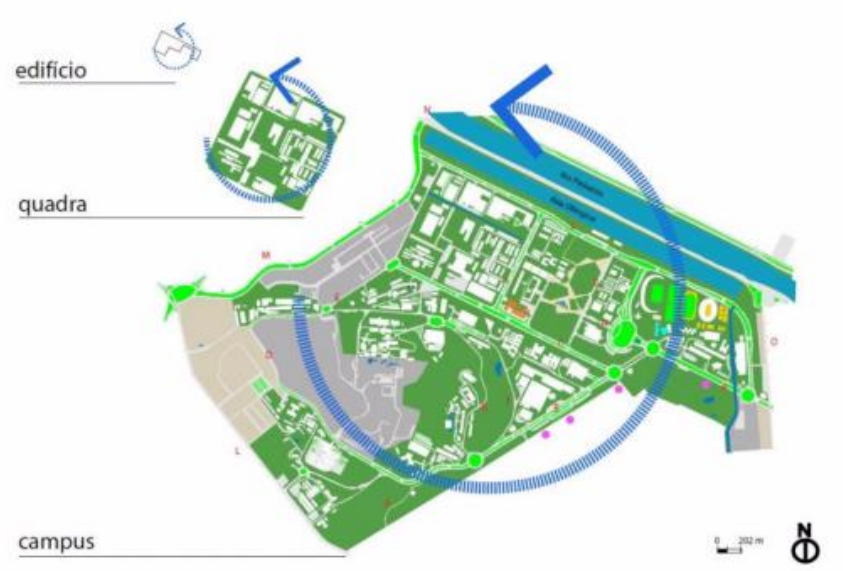

Figura 76- Integração entre as escalas edifício- quadra- Campus. Projeto de Taicia H.N. Marques, sem data. (Fonte: Pellegrino, 2015, p. 06). 
Esse sistema projetual aproxima-se com o utilizado na Universidade de Oregon.

Outro projeto foi a recuperação de áreas verdes do Departamento de Artes Plásticas e da Faculdade de Educação através da criação de jardins que integrassem os espaços culturais e naturais.

Por fim, o último projeto selecionado foi a proposta de, a partir de pesquisas e entrevistas, compreender como a comunidade vê a sustentabilidade e como seria possível aumentar o conhecimento dos mesmos sobre o assunto.

Nem todos os projetos selecionados foram colocados em prática em consequência dos cortes orçamentários.

Em 2015 outros projetos foram aprovados através do Programa Campus Sustentável cujo objetivo é integrar pesquisa, ensino, cultura, extensão e projetos sustentáveis que incluam não somente a USP mas também a cidade de São Paulo. Esse projeto tem a duração de vinte anos e irá desenvolver e aplicar projetos e políticas para o campus, para as áreas internas dos edifícios e para seu entorno na cidade. O objetivo é que a USP possa, em 2034, quando finda o projeto, ser referência nacional de sustentabilidade e possa ser reconhecida em rankings internacionais.

Outros projetos também tiveram destaque como por exemplo o projeto de diminuição do desperdício do restaurante universitário que ficou em quarto lugar em um concurso da ONU que reuniu projeto de 80 países $^{147}$. A economia de um ano chegou a 12 toneladas de alimentos.

As atividades do campus 1 da USP São Carlos foram iniciadas na década de 1950 e, atualmente, ele se encontra localizado em uma região urbana central e densa, ou seja, não há mais possibilidades da universidade crescer fisicamente, apesar da demanda.

As demandas para o crescimento físico da universidade começaram no final dos anos de 1990 com a escassez de vagas, a necessidade de expansão de espaços para os cursos existentes de Computação e Engenharia Ambiental, além da necessidade de incrementar pesquisas e um espaço para o curso de Engenharia Aeronáutica . Era imprescindível ampliar o campus .

Por essas necessidades, em 2001 foi iniciado o plano para o campus 2 através do Projeto de Expansão das Universidades Públicas Estaduais.

\footnotetext{
$147 \mathrm{http} / /$ g1.globo.com/sp/sao-carlos-regiao/noticia/2015/03/campanha-paradiminuir-desperdicio-deixa-usp-em-4-em-concurso-da-onu.html
} 


\subsection{Estudo de caso: o campus 2 da Universidade} de São Paulo, campus São Carlos

O campus 2 da Universidade de São Paulo, São Carlos, está inserido no limite urbano em uma área noroeste, Jardim Santa Felícia, que é predominantemente residencial e em expansão.

A área do campus 2 tem de cerca de 146 hectares e possui um terreno ameno com vegetação predominantemente de pinus e um solo proveniente de antigas plantações de cana de açúcar; no terreno também há três córregos, sendo um com nascente no próprio campus, e suas matas ciliares.

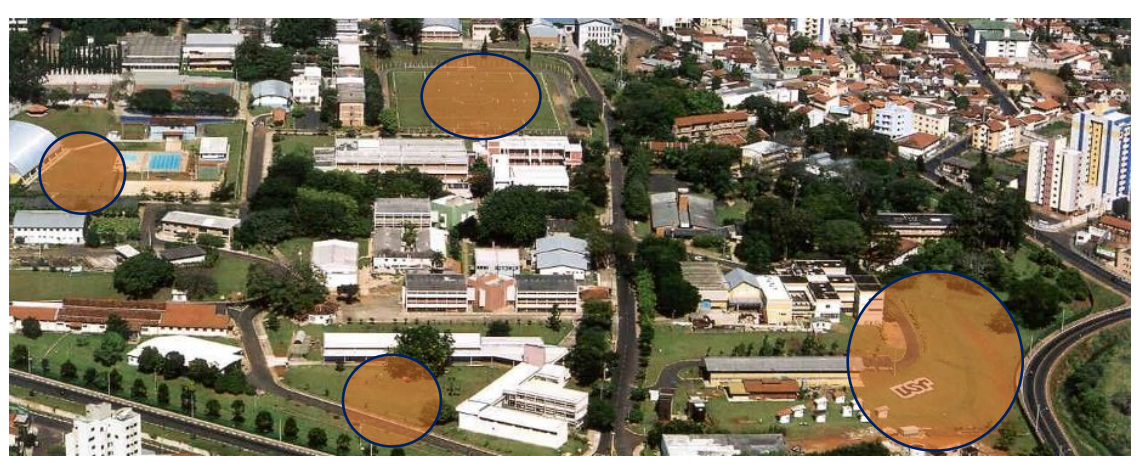

Figura 77- Vista aérea do campus 1 da USP São Carlos mostrando sua alta densidade e limite com a cidade. As áreas circuladas são espaços de lazer e voltados para pesquisa, sem data.

(Adaptado de: http://blog.filipesaraiva.info/?p=1216, acessado dia 19 de fevereiro de 2017, as 19:37 hrs).
O terreno está localizado em uma importante microbacia chamada microbacia do Córrego Mineirinho, inserida na bacia do Rio Monjolinho. A rápida urbanização da área desta microbacia contribuiu para a sua degradação e fragilidade ambientais (Silva et al., 2014).

A área de matas ciliares dentro do campus 2 somam 25\% de sua área total (Lanna, 2003).

Um desafio para o planejamento do espaço do campus foi manter uma harmonia no desenho espacial que unisse o meio ambiente, o percurso natural dos rios, a vegetação e sua preservação, o transporte interno e os edifícios.

Segundo Schenk (2011) a vizinhança possui distintas paisagens derivadas de diferentes épocas: a primeira é relacionada aos loteamentos populares voltados para a população menos privilegiada que acabou sendo expulsa para áreas periféricas, e a segunda provem de classes com maior poder aquisitivo que construíram na região condomínios fechados. Até os dias de hoje existem muitos vazios urbanos resultantes de fragmentações e desmembramentos de lotes que tiveram uma ocupação descontínua. 


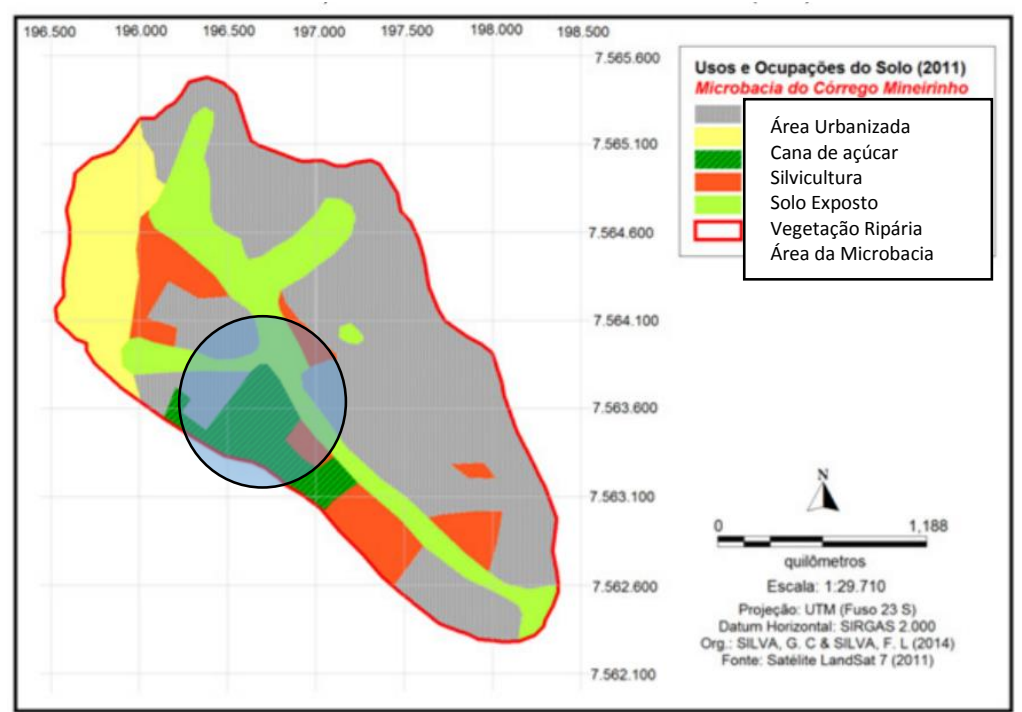

Figura 78- Mapa do uso e ocupação do solo da microbacia do Córrego Mineirinho, São Carlos, 2011. Em destaque a localização do campus 2 da USP.

(Adaptado de: Silva et al., 2014, p. 06).

Outro desafio projetual para essa grande área seria criar um desenho e atrativos que incluíssem a comunidade acadêmica e a dos bairros vizinhos (Jardim Santa Felícia, Loteamento São Carlos 3 e Jardim Santa Angelina). Os primeiros projetos e propostas se preocupavam com essa questão, como a inclusão de uma pista de skate e um teatro ao ar livre que poderiam ser utilizados em conjunto por ambas as comunidades, ideias como essas foram barradas nas apresentações dos projetos pois foram consideradas desnecessárias pelos dirigentes de então.

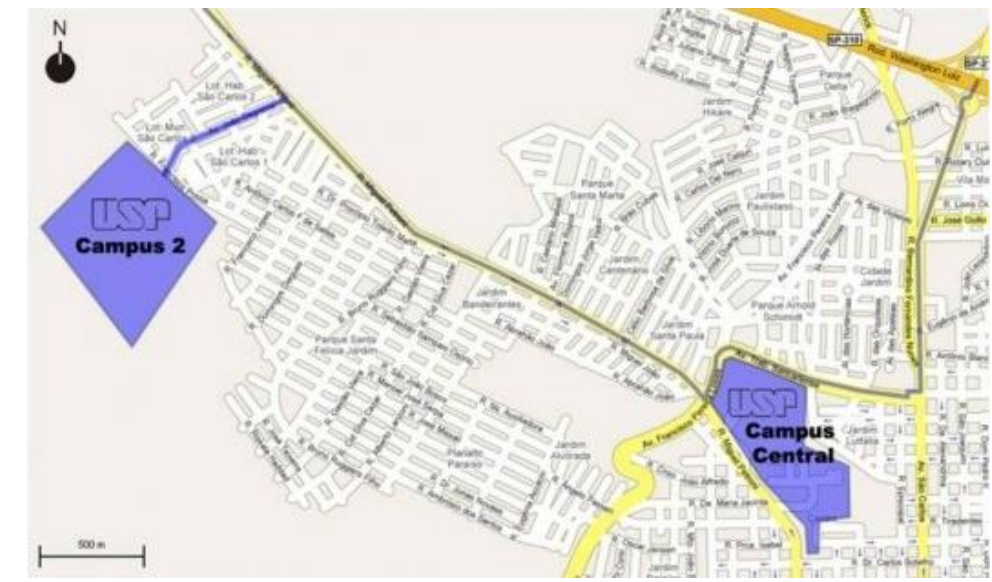

Figura 79- Os Campus 1 e 2 da USP São Carlos inseridos na malha urbana. (Fonte:

http://www.vitruvius.com.br/revistas/read/arquitextos/17.197/6261, acessado dia 19 de fevereiro de 2017, as 18:17 hrs).

Os projetos para o novo campus em um terreno de 1.024.242, $54 \mathrm{~m} 2$ deram-se por duas equipes formadas por profissionais do atual Instituto de Arquitetura e Urbanismo, IAU, da USP São Carlos: a primeira equipe coordenada pelo arquiteto e professor doutor Carlos Roberto Monteiro de Andrade, responsável pelo plano urbanístico, e a segunda coordenada pelo arquiteto e professor doutor Gelson de Almeida Pinto, responsável pelos projetos arquitetônicos ${ }^{148}$. 
Em 2002 as esquipes foram dispensadas e, enquanto os projetos urbanísticos para o campus 2 foram desenvolvidos em pequenas proporções, os projetos para os edifícios passaram a ser responsabilidade da Coordenadoria do Espaço Físico, COESF, de São Paulo ${ }^{149}$.

Em 21 de fevereiro de 2002 o campus 2 recebeu uma doação de mais 78 hectares de terra das empresas Faber Castell e Sobloco, o que possibilitou aumentar o espaço destinado a construção de novos edifícios e adequar o projeto viário interno. Em 2004, a empresa Novo Tema Empreendimentos doou mais 24,4 hectares para o novo campus $^{150}$. (acessado dia 19 de fevereiro de 2017, as 18:10 hrs).

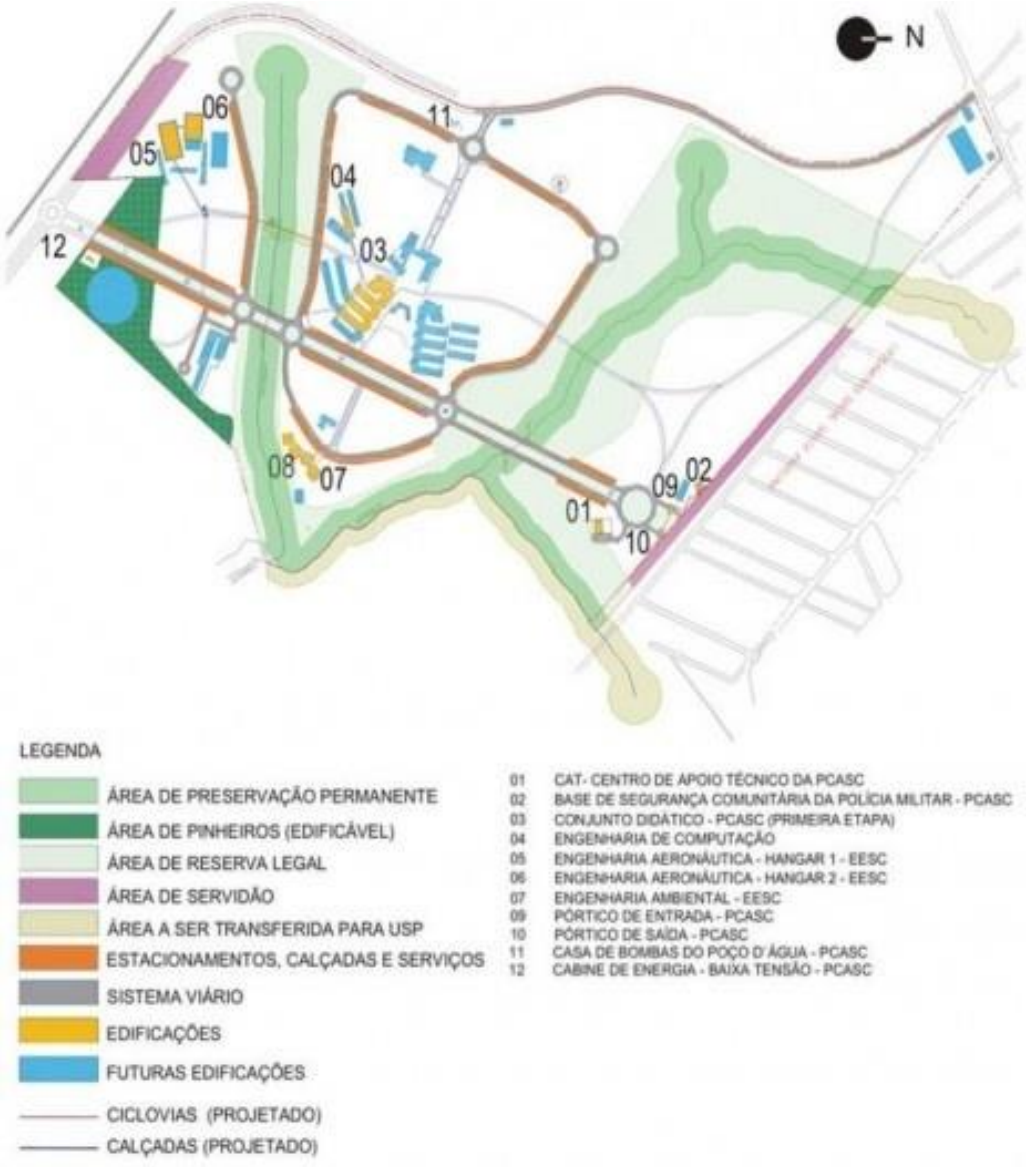

Figura 80- Projeto de urbanismo criado pela equipe do professor $\mathrm{dr}$. Carlos R. M. de Andrade para o campus 2 da USP São Carlos. (Fonte:

http://www.vitruvius.com.br/revistas/read/arquitextos/17.197/6261, acessado dia 19 de fevereiro de 2017, as 18:17 hrs).

$150 \mathrm{http}: / /$ www.saocarlos.usp.br/index.php?option=com content\&task=view\&id= 14401\&ltemid=200 (acessado dia 19 de fevereiro de 2017, as 19:53 hrs). 
Oficialmente o campus 2 foi inaugurado dia 4 de novembro de 2005, quando passou a contar com atividades acadêmicas ${ }^{151}$. O primeiro edifício inaugurado foi o do curso de Engenharia de Computação, em 15 de janeiro de $2005^{152}$.

Mesmo nos primeiros projetos, a partir de 2001, a preocupação com a preservação das APPs e com a sustentabilidade ${ }^{153}$ estavam presentes, como apresentados em documentos ${ }^{154}$.

Em documento assinado pela Comissão de Implantação do campus apresenta os três princípios utilizados: (a) criar um campus sustentável que preserve as matas já existentes, respeite as condições climáticas locais, elimine os tipos arquitetônicos que possam funcionar como barreiras e que se comprometa a utilizar de materiais e técnicas que economizem energia dentro do "princípios dos três erres (Redução, Reciclagem, Reutilização)"; (b) criar um processo de planejamento participativo e conjunto com a comunidade da universidade e da cidade, especialmente a população dos bairros vizinhos; (c) criar um bom relacionamento do campus com a cidade, essa intenção estaria inclusa em um projeto de um parque público com equipamentos que todos os moradores de São Carlos e região pudessem utilizar (Schenk, 2011, p. 91).

151 http://www.saocarlos.usp.br/index.php?option=com_content\&task=view\&id= 61\&Itemid=87 (acessado dia 19 de fevereiro de 2017, as 19:25 hrs).

$152 \mathrm{http}$ ://www.saocarlos.usp.br/index.php?option=com_content\&task=view\&id= 14401\&ltemid=200 (acessado dia 19 de fevereiro de 2017, as 19:53 hrs).

${ }^{153}$ Segundo Lanna (2003), área do campus 2 começou a ser utilizada em 2002 para pesquisas e por esse motivo a área precisou ser preservada ambientalmente; a

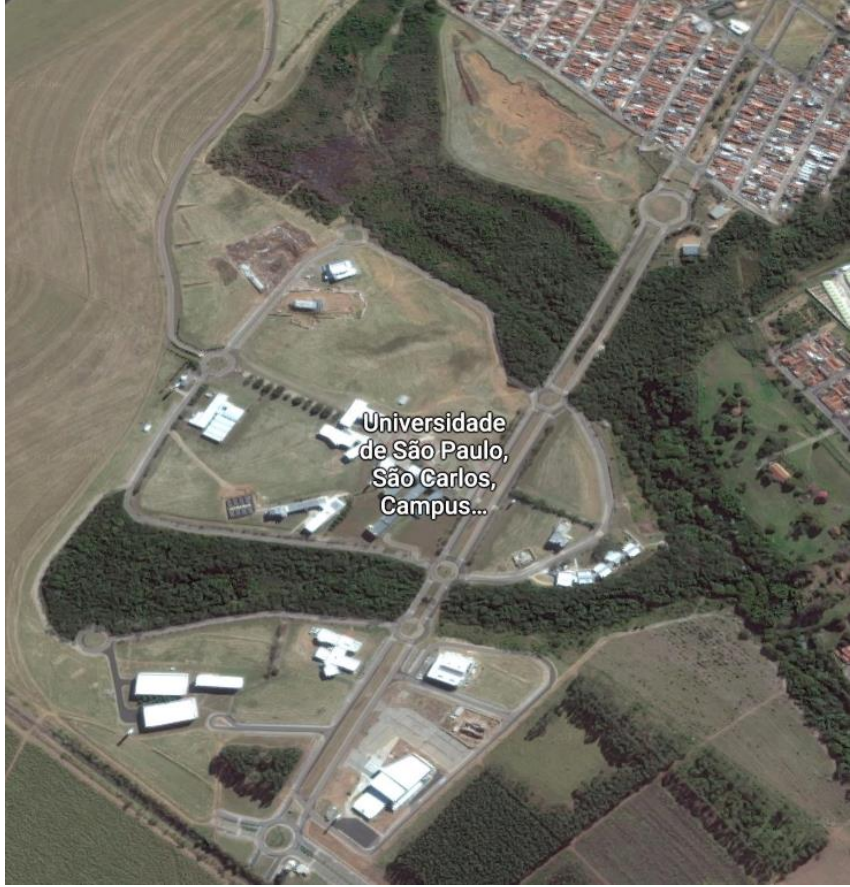

Figura 81 - Vista aérea do campus 2 da USP São Carlos, 2017. (Fonte:

https://www.google.com.br/maps/place/Universidade+de+S\%C3\%A3o+Paulo,+S\% C3\%A3o+Carlos,+Campus+-+\%C3\%81rea+2/@-22.0244489,-

47.9290076,3003a,20y,40.84t/data=!3m1!1e3!4m5!3m4!1s0x94b87a0d804efd0b :0x7a9f2feb072ed9c1!8m2!3d-22.0018199!4d-47.9307183, acessado dia 19 de fevereiro de 2017, as 23:22 hrs).

área sendo um grande espaço aberto para pesquisas precisava inserir a sustentabilidade em seu amplo conceito, principalmente o ambiental e o social. 154 Como exemplo é possível observar em http://www.saocarlos.usp.br/index.php?option=com_content\&task=view\&id=14 401\&Itemid $=200$ 
Apesar dos princípios propostos, a implantação do campus deu-se da seguinte maneira:

"A implantação do campus teve como diretriz uma ocupação integral do terreno, como forma de estabelecer o domínio total da área, o que justificou o investimento em concluir num primeiro momento todo o sistema de vias. O eixo viário principal foi direcionado pelas torres de alta tensão que cortam a área do campus. Uma via secundária formou um anel que foi delimitado pelas áreas de APP ${ }^{155}$ e Reserva Legal. No sentido perpendicular ao eixo de acesso, um passeio para pedestres ligou os outros dois extremos da área. A organização espacial do campus foi baseada em três características marcantes da área, o eixo das torres de alta tensão, a topografia e as áreas verdes. Estas são compostas de vales com nascentes e mata ciliar, delimitadas com base no levantamento ambiental. A topografia (...) possibilitou a valorização de visuais do próprio campus, das áreas verdes e da cidade. O passeio para pedestres que liga dois extremos do campus (...). A partir do ponto mais elevado desse eixo, há um panorama do campus e observa-se uma valorização do trecho com a presença de arborização, bancos e esculturas. (...) os primeiros edifícios foram implantados distantes uns dos outros e não estabeleceram entre si nenhuma referência ou ligação. Observa-se o espalhamento dessas unidades pela malha viária. Esta conformação do espaço não valorizou o convívio dentro do campus" ${ }^{156}$.

\footnotetext{
155 Área de Preservação Permanente.

$156 \quad$ http://www.vitruvius.com.br/revistas/read/arquitextos/17.197/6261

(acessado dia 19 de fevereiro de 2017, as 18:10 hrs).
}

Os três princípios propostos, até os dias de hoje, não foram seguidos.

Outros fatores que não seguiram as diretrizes para o projeto do campus são a falta de uma ciclovia, a presença de uma via estruturadora que atravessa o córrego através de uma ponte prémoldada que acabou por alterar a hidrologia do local, os edifícios são isolados e com acessos inóspitos, os estacionamentos ocupam as frentes dos edifícios fazendo com que o protagonista do campus seja o automóvel, como também foi construído um muro com seguranças que isolam os bairros vizinhos do espaço da universidade e acabam com a proposta de inclusão da comunidade local (Schenk, 2011).

Um dos objetivos para o campus 2, apresentado em Proposta de diretrizes para a elaboração de Plano Diretor de Ocupação da Área 2 do Campus de São Carlos (Anexo A, p. 02), em 2011, é:

"Ampliar de maneira significativa as práticas e procedimentos, construtivos e de uso, de caráter sustentável, em especial nos âmbitos de otimização energética, dispositivos de reuso de água, coleta e tratamento de resíduos, etc".

A principal questão apontada por Shenk (2011) é a dissonância entre proposta original que integrava os documentos do projeto da então Área 2 do Campus da USP São Carlos e o que vem sendo construído. Seu projeto ainda utiliza modelos anteriores onde não 
existia articulação entre os edifícios e a paisagem original. Fatores sustentáveis como captação e reutilização de água de chuvas ou mesmo a construção em congruência com o relevo da área (Schenk, 2011).

Em 2013, após duas reuniões do grupo de trabalho formado para a elaboração do plano diretor do atualmente denominado campus II foram propostas diretrizes para ocupação ${ }^{157}$. O objetivo principal é otimizar a ocupação da área evitando os problemas encontrados pela ocupação do campus I. Os objetivos específicos contemplam a ampliação do coeficiente de aproveitamento (área construída/área do terreno), diminuição da taxa de ocupação (projeto da construção/área do terreno), ampliar as taxas de permeabilidade e de cobertura vegetal, considerar o deslocamento de pedestres como objetivo principal de mobilidade nas áreas centrais, ampliar as práticas e procedimentos de construção sustentável (especialmente no âmbito energético) e otimizar o planejamento da implantação e gestão de serviços (Anexo A).

As diretrizes gerais de ocupação mantem o zoneamento temático presente no campus I, propõe a otimização da ocupação e sua avaliação periódica para verificação da necessidade de revisões e, também, a articulação da proposta física com o planejamento estratégico acadêmico.

Em concordância com as diretrizes gerais foram propostas diretrizes físicas sendo a adequação a insolação e ao regime de ventos; o estímulo a verticalização e a racionalização de projetos, processo e sistemas construtivos; garantia das condições de deslocamento pedestre, bolsões periféricos de estacionamento e, o que seria mais importante principalmente para este trabalho, a implantação de sistemas e práticas sustentáveis tanto na construção como no uso das instalações físicas da então Área 2 (Anexo A).

Para a solução destas questões foi proposta uma grelha virtual para a definição de implantação de novos edifícios e equipamentos. A grelha deve ser utilizada para definição de parâmetros de construção, como definido pelo objetivo principal das diretrizes propostas, e para adequações do projeto viário.

A grelha virtual considerou os estudos de insolação e de ventos, a topografia do campus, o sistema viário já implantado, as construções existentes e projetos em andamento, as normas e parâmetros de dimensionamento de espaços universitários, juntamente com as normas de recuos e afastamentos de novas edificações, elaboradas pela Coordenadoria do Espaço Físico, COESF (Anexo A).

Os parâmetros resultaram em um módulo-base retangular de $11,70 \times 21,60$ metros considerando a área do edifício sem os recuos e afastamentos. Exemplos de ocupação podem ser vistos na Figura 82. Outros exemplos de ocupação podem ser vistos no Anexo A.

Em 2015, o reitor da USP Marco Antonio Zago criou a Comissão de Planejamento Acadêmico para o novo Campus USP de

${ }^{157}$ www.ccsc.usp.br/arquivos/diretrizes_ocup\%20Campus_2_ago\%2013.pdf 
São Carlos (Anexo B) que deverá: (a) elaborar diretrizes acadêmicas para o desenvolvimento do novo campus; (b) traçar diretrizes de planejamento que deverão ser inseridas no Plano Diretor de Desenvolvimento Físico e Urbanístico das áreas do novo campus, Plano Diretor também a ser criado; (c) apresentar setores e equipamentos adequados para os projetos de novos edifícios e equipamentos; (d) criar projetos que visam otimizar a estrutura administrativa do campus 2. Essa comissão passou a substituir a Comissão Acadêmica e Comissão de Implantação do Campus 2 de $2002^{158}$.

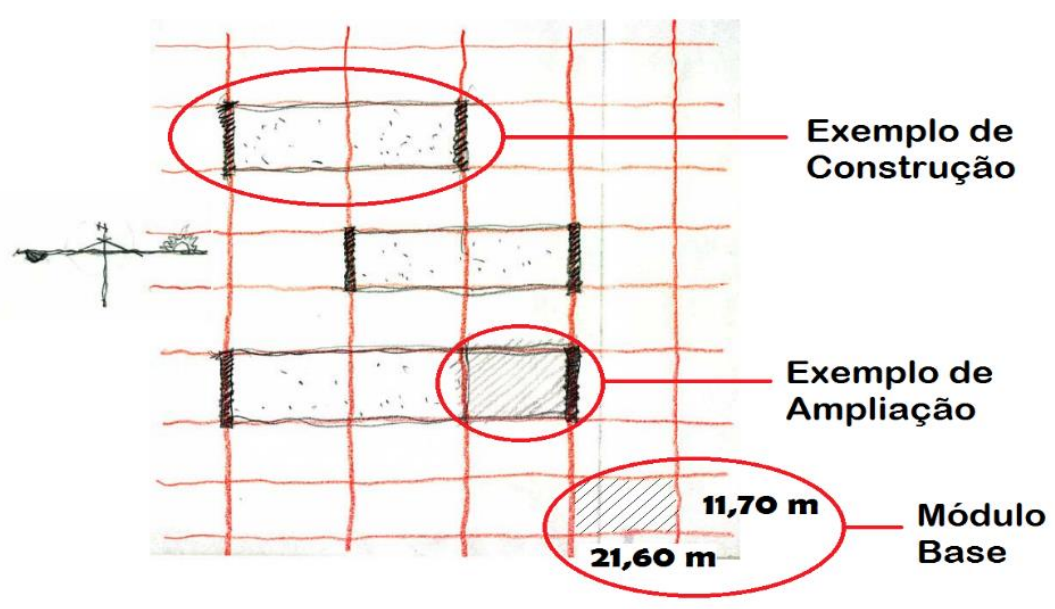

Figura 82- Exemplo de ocupação do grid virtual do campus II da USP (Forte: adaptado do Anexo A).

158 http://www.saocarlos.usp.br/index.php?option=com_content\&task=view\&id= 20296\&ltemid=171 (acessado dia 19 de fevereiro de 2017, as 20:15 hrs).
Em 2015 também foi criado pelo Grupo de Estudos e Intervenções Socioambientais, da Escola de Engenharia em parceria com a Prefeitura do Campus, a Superintendência de Gestão Ambiental e o Centro de Divulgação Científica e Cultural, o Projeto 'Proteção, Recuperação de Áreas Degradadas e Educação Ambiental na Reserva Ecológica da Área 2 do Campus da USP de São Carlos' para a recuperação das áreas verdes do campus 2 .

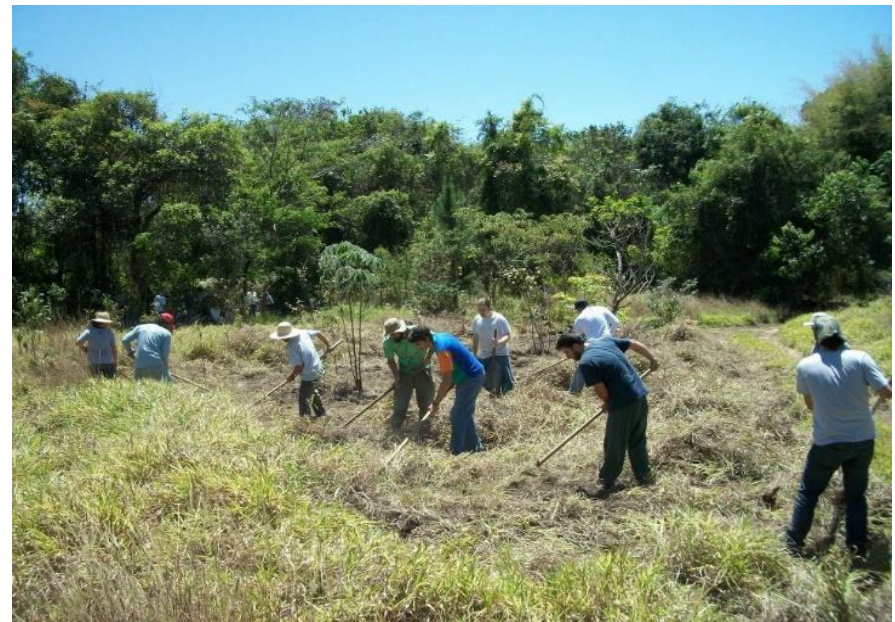

Figura 83- Membros do Grupo de Estudos e Intervenções Socioambientais trabalhando para a implantação de um Sistema Agroflorestal na área de mata ciliar dentro do Campus 2 da USP, sem data.

(Fonte: http://girasolagroeco.blogspot.com.br/2012/10/mutirao-em-saocarlos-29092012.html, acessado dia 19 de fevereiro de 2017, as 20:42 hrs). 
O grupo é formado por alunos da Engenharia Ambiental e desde 2012 vem trabalhando com a regeneração de uma área do campus 2. Neste novo projeto a equipe, através de métodos agroflorestais, buscam recuperar e proteger áreas degradadas desse campus.

Esse grupo também realiza um trabalho social com alunos moradores do Jardim Santa Felícia com o campus para "conhecer e articular as demandas e expectativas da sociedade", além de realizar "um diagnóstico socioambiental de toda a população local"159.

Diversas iniciativas estão sendo desenvolvidas nos diversos campi da Universidade de São Paulo para implantar de forma completa e permanente a sustentabilidade na universidade. Em São Carlos a construção do campus 2 se mostrou uma boa oportunidade para o desenvolvimento de projetos que encontram diversos problemas de implantação e operação como descrito neste capítulo. Apesar dos problemas, os esforços realizados mostram que a universidade avança nas questões sustentáveis em conformidade com o que ocorre nas universidades por todo o mundo e que existe a preocupação em tornar o campus universitário um local mais sustentável em todos os sentidos.

159 https://www.usp.br/imprensa/?p=50667 (acessado dia 19 de fevereiro de 2017 , as 20:15 hrs). 


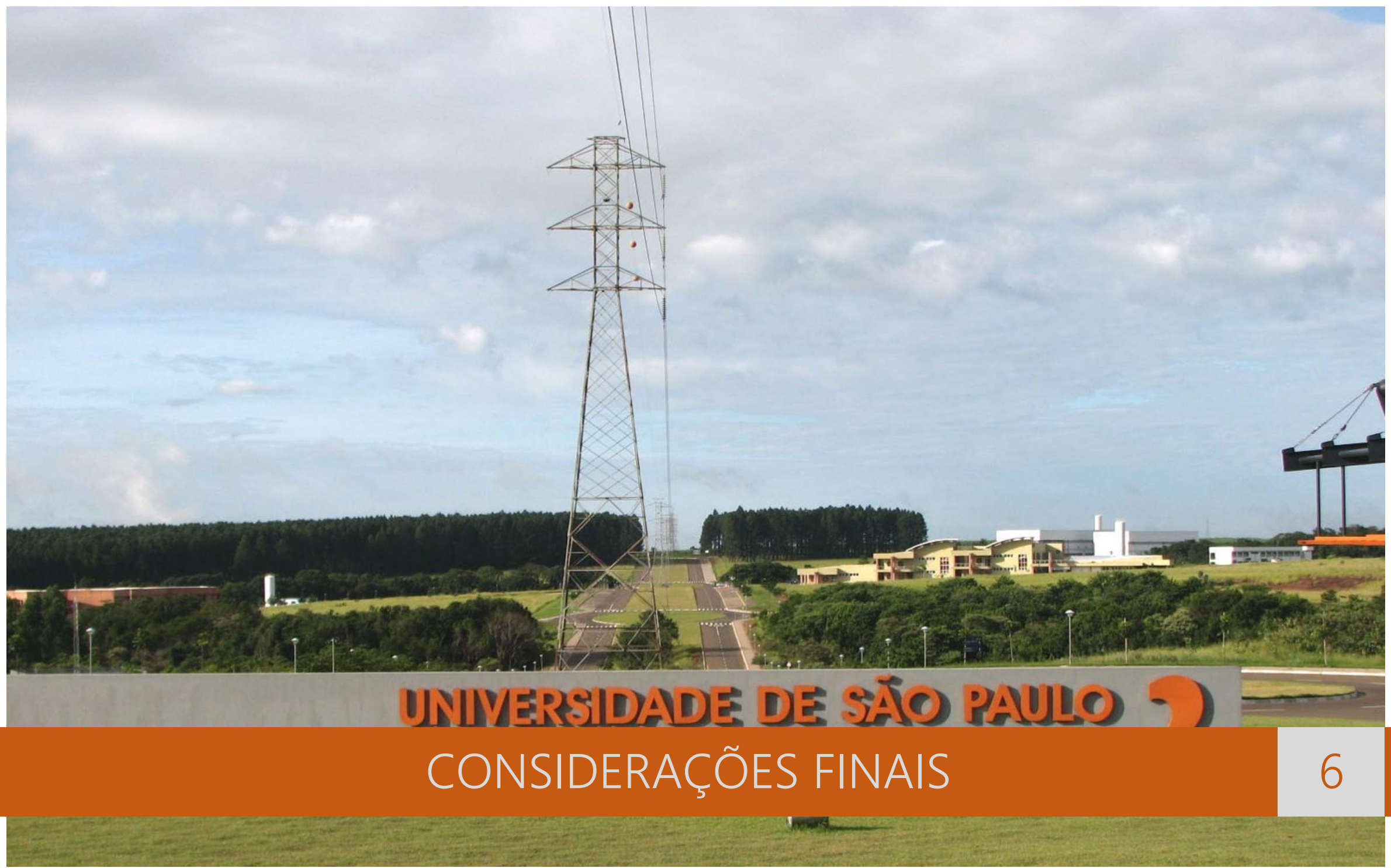


https://www.google.com.br/search?q=campus+2+usp+s\%C3\%A3o+carlos\&safe=off\&espv=2\&biw=1920\&bih=947\&source=Inms\&tbm=isch\&sa=X\&ved=0ahUKEwigkpTvysbOA hUI6x4KHcNjAPOQ_AUICCgD\#imgdii=QDJWvot-_YFhcM\%3A\%3BQDJWvot-_YFhcM\%3A\%3BcDti-RzLeFd3XM\%3A\&imgrc=QDJWvot-_YFhcM\%3A (acessado dia 19 de junho de 2016, as 22:16 horas). Editada pela autora. 


\section{CONSIDERAÇÕES FINAIS}

A sustentabilidade é um tema de alta relevância atualmente, principalmente pelo estado no qual se encontra o planeta. Ao analisarmos os caminhos e iniciativas em relação ao tema, nada mais natural do que pensarmos em aplicar seus princípios no meio acadêmico e também no campus universitário, especialmente partindo do pressuposto da qualidade exemplar que a universidade deve trazer.

Considerando o caráter técnico-científico da universidade contemporânea é imprescindível que o tema da sustentabilidade seja incluído de todas as formas possíveis na formação dos futuros profissionais seja em sua atuação no mercado ou em pesquisa para o desenvolvimento de soluções inseridas no contexto ambiental atual.

A universidade que antes tinha um caráter independente teve que se adaptar ao fato de que a infraestrutura necessária para a vida no campus é provida também, em partes, pela cidade da qual participa. Neste contexto existe uma relação de dependência, de compromisso e complementariedade na qual a universidade, inserida em um contexto urbano, deve não somente apresentar soluções para seus problemas internos, similares aos problemas urbanos já que o campus hoje pode ser considerado uma 'Cidade Universitária'. Por outro lado, como também pode ser considerada modelo a ser seguido na solução de problemas externos e, se possível, auxiliar nas soluções permitindo assim sua integração com a comunidade.

O estudo proposto inicia-se com as principais definições relacionadas à sustentabilidade e o desenvolvimento do conceito desde seus primórdios. Em seguida uma discussão sobre como o sistema capitalista é antagônico com relação ao conceito da sustentabilidade e a apresentação das mudanças ocorridas no mundo com os novos paradigmas da relação entre homem e natureza. Por fim os conceitos de urbanismo sustentável e arquitetura sustentável são apresentados e posicionados de acordo com a situação das cidades modernas.

Após o amplo entendimento da sustentabilidade e de sua pluridimensionalidade, o histórico do surgimento das universidades é 
apresentado. O domínio deste percurso histórico é primordial para o entendimento de como a universidade atual pode ser projetada e quais as consequências de se seguir modelos passados. Este histórico inicia-se com o modelo clássico e o domínio islâmico e em seguida se volta para a Europa e o período medieval. A demanda de novos profissionais apresentada pela revolução industrial abre a discussão com foco em mudanças, e também as portas para a universidade moderna e contemporânea. O estudo histórico encerra-se com a questão relacionada às Américas, em especial, no Brasil.

Compreendendo o nascimento e a evolução das universidades é possível estudar o território universitário e suas interações com a cidade. Este estudo engloba as definições de campus universitário, campi universitários e também a cidade universitária. Neste capítulo também foram detalhados casos importantes de campus nos estados unidos e as cidades universitárias brasileiras com suas particularidades e seu amplo campo de atuação para a sustentabilidade. Neste momento pretendeu-se constituir o embasamento teórico necessário para a principal discussão no qual este trabalho está construído.
A junção dos conceitos apresentados pretende apresentar uma possível forma de concepção do campus sustentável. O capítulo 5 apresentou, portanto, uma discussão das diretrizes que promovem a implementação da sustentabilidade nas universidades segundo pesquisadores da área, que em síntese são: (a) a formalização do compromisso da instituição com a sustentabilidade; (b) a preocupação dos gestores e líderes com o tema; (c) o estabelecimento de uma forma consistente de avaliar o desempenho institucional em relação à sustentabilidade; (d) a participação dos professores e funcionários; (e) e a inclusão da sustentabilidade nos currículos.

Conhecendo, portanto, os conceitos e diretrizes é possível entender os métodos de avaliação disponíveis e se posicionar de forma crítica em relação a eles. O capítulo apresenta em seguida diversos exemplos de medidas sustentáveis aplicadas no mundo e no Brasil direção a sustentabilidade nos campi.

É também importante ressaltar que existem no país vários campi que tentaram, de uma maneira ou outra, tornar-se mais sustentáveis; o problema, algumas vezes, quando a instituição de ensino superior acaba utilizando do propósito sem amplos estudos, 
comissões e um verdadeiro comprometimento. É não somente a falta de compreensão ampla do termo, mas o esvaziamento que o mesmo acaba sofrendo pela superexposição, em outras palavras, a universidade acaba fazendo do conceito uma chave ideológica para tornar-se mais atrativa.

Outras vezes, quando há um esforço que mobiliza vários profissionais de um campus, a barreira torna-se o problema financeiro uma vez que esse comprometimento não mobiliza os dirigentes e, novamente, a compreensão por parte de quem ocupa grandes cargos para o destino da verba, e acaba sendo um fator que bloqueia inovações na área.

Esta dissertação encerra-se apresentando seu objetivo geral que foi a análise do estudo de caso sobre o desenvolvimento do campus 2 da universidade de São Paulo, São Carlos, que vem buscando ser um espaço sustentável. É importante lembrar que a Universidade de São Paulo, desde sua fundação, segue o modelo estadunidense por apresentar um campus onde ficam reunidos todos os elementos necessários para o ensino e pesquisa mantendo a autonomia de cada departamento, faculdade e/ou instituto. Este modelo permite então o projeto específico com soluções direcionadas a cada necessidade.

No projeto do campus 2 da USP de São Carlos todo o conhecimento apresentado foi aplicado inicialmente e, por motivos financeiros e políticos, estes projetos foram modificados até que não restasse mais do que a essência das ideias no projeto final.

A proposta para o campus 2 inicialmente seguiu todas as diretrizes que promovem a implementação da sustentabilidade nas universidades conforme apresentadas nesse trabalho de pesquisa; a USP formalizou seu compromisso institucional com a sustentabilidade, compromisso este que ainda é uma preocupação (como é possível analisar no Anexo B); existiram líderes preocupados com a temática e houve a inclusão de docentes e funcionários em equipes que trabalharam nos projetos.

Falta ainda uma maneira interna e efetiva para que a instituição possa avaliar seu desenvolvimento institucional em relação à sustentabilidade, o novo espaço sequer possui um Plano Diretor o que acaba por dificultar a aplicação, avaliação e até verificação dos objetivos que o campus possui; além dos curriculares 
dos distintos cursos não serem ambientalizados, já que nem todos os docentes compreendem a importância do tema.

Ao analisarmos o próprio projeto do campus 2 nada diferente foi construído do que já é possível observar há décadas em outros campi de outras universidades, a proposta sustentável perdeu-se em palavras e a realidade não faz jus ao que poderia ser um modelo para o país.

O resultado atual do campus 2 é uma ampla área murada e composta por poucos prédios distantes uns dos outros e ligados por uma extensa avenida, no próprio campus não há muito o que possa remeter à sustentabilidade, seja em questões construtivas, seja na ciclovia não instalada, seja nas áreas verdes que necessitam de um maior cuidado, seja no rio que teve sua hidrologia alterada, seja na vizinhança que permanece isolada, seja na degradação ambiental da região ou seja nos resíduos presentes nas áreas verdes; a sustentabilidade foi reduzida à lixeiras de coletas seletivas e algumas iniciativas estudantis que ficaram no passado.

Esta situação inevitavelmente nos leva a uma análise crítica de toda a situação e a conclusão de que não existem campi realmente sustentáveis, projetos realmente implementados, rankings realmente compromissados em avaliar as universidades. O que se percebe é um movimento de intenções sustentáveis resultando em um mínimo de ações e programas eficientes que estão longe de transformarem campi universitários em campi sustentáveis. E quando se tem a iniciativa real e a oportunidade de implantação do projeto sustentável esbarra-se em outros tipos de problemas limitantes, resultando em soluções da mesma natureza do que é praticado desde os primeiros campi universitários modernos.

A justificativa desta pesquisa foi a necessidade se criar uma referência mais atualizada sobre o desenvolvimento de campus sustentável, durante a pesquisa foi observada a necessidade de trabalhos futuros que vão além da teoria, podendo, inclusive, modificá-la já que há uma carência de modelos reais no país. Ao concluir o estudo proposto é notável a necessidade de políticas, medidas e programas eficazes que contemplem a pluridimensionalidade da sustentabilidade para que em um próximo momento seja possível estabelecer novamente um estudo, porém neste caso, com resultados de mudanças eficazes e campi sustentáveis que possam servir de modelo para a construção de 
novos campi que contemplem as soluções encontradas e discutidas para o problema. 


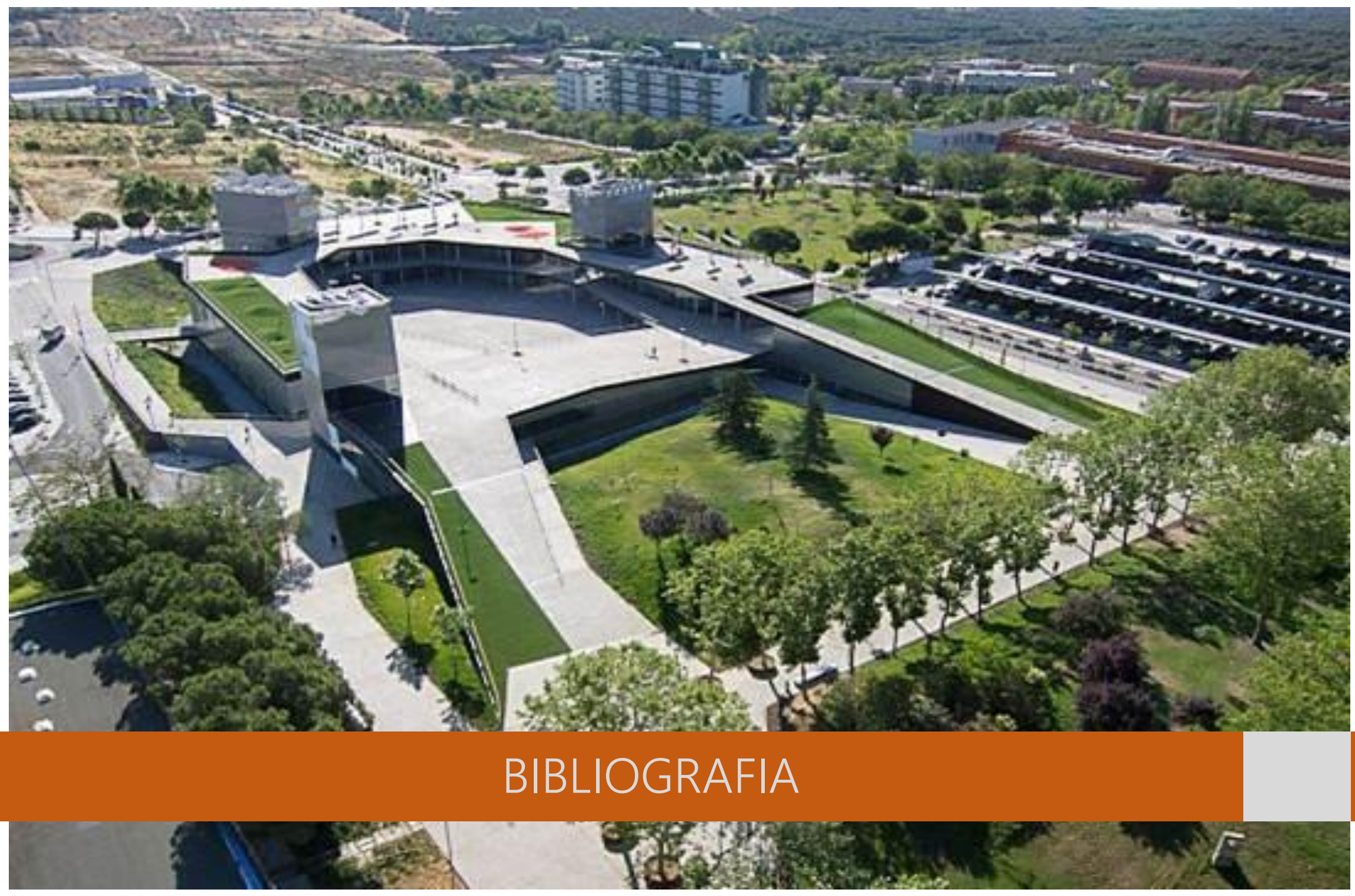


Universidad Autonoma de Madrid.

Fonte da imagem: http://rfcas.eps.uam.es/ursi2016/uam.php (acessado dia 24 de fevereiro de 2017, as 15:16 horas). Editada pela autora. 


\section{BIBLIOGRAFIA}

AGOPYAN, V.; JOHN, J. G. O desafio da sustentabilidade na construção civil. São Paulo: Blucher, 2011.

ÁLAMO, J. B.; MASSAMBANI, O. (Org.). No caminho para a SUSTENTABILIDADE: Desafios e aprendizagens compartilhados entre a Universidade de São Paulo e a Universidade Autônoma de Madri. Madri: Agência Espanhola de Cooperação Internacional para o Desenvolvimento, 2010.

ALBERTO, K. C. Formalizando o ensino superior na década de 1960: a cidade universitária da UnB e seu projeto urbanístico. Tese. Rio de Janeiro, UFRJ, 2008.

ALEXANDER, C. A city is not a tree. Design Magazine, London: Council of Industrial Design, Londres, n. 206, p. 01-17. 1966. Disponível em < http://www.chrisgagern.de/Media/A_City_is_not_a_tree.pdf>. Acesso em: 17 jul. 2016.

ALEXANDER, C.; ISHIKAWA, S.; SILVERSTEIN, M.; JACOBSON, M.; FIKSDAHL-KING, I.; ANGEL, S. A Pattern Language: Towns, Buildings, Construction. Nova lorque: Oxford University Press, 1977.

ALEXANDER, C.; SILVERSTEIN, M.; ANGEL, S.; ISHIKAWA, S.; ABRAMS, D. (1975). The Oregon Experiment. 2a reimpressão. Nova lorque: Oxford University Press, 1979.

AMARAL, L.P.; MARTINS, N.; GOUVEIA, J.B. Quest for a sustainable university: a review. International Journal of Sustainability in Higher Education, p. $155-172,2015$.

AN INCOVENIENT TRUTH. Dirigido por Davis Guggenheim, produzido por Lawrence Bender, Scott Burns, Laurie Lennard e Scott Z. Burns. Elenco: Albert Arnold Gore Júnior. Estados Unidos: Lawrence Bender Productions/ Participant Productions, 2006. Documentário (100 min), color, 35 mm. Disponível em: < https://www.youtube.com/watch?v=MwxMrnDkbPU>. Acesso em 15 mai. 2016.

ANDRADE, C. R. M.; PAVESI, A. O planejamento de campi universitários como prática participativa e educativa. R. B. Estudos Urbanos e Regionais, v. 14, n.1, p. 187-196, 2012.

ARCIPRESTE, C. M. Entre o discurso e o fazer arquitetônico: reflexões sobre o ensino de arquitetura e urbanismo e seus referenciais a partir do trabalho final de graduação. 2012. 287 f. Tese (Doutorado em Arquitetura e Urbanismo) - Faculdade de Arquitetura e Urbanismo, Universidade de São Paulo. 2012.

ARGAN, G. C. Arte moderna: do iluminismo aos movimentos contemporâneos. 3ạ reimpressão. São Paulo: Companhia das Letras, 1995.

ARRUDA, L.; QUELHAS, O. L. G. Sustentabilidade: um longo processo histórico de reavaliação crítica da relação existente entre a sociedade e o meio ambiente. B. Téc. Senac: a R. Educ. Prof., Rio de Janeiro, v. 36, n. 3, p. 53-63, set./ dez. 2010. 
BARBA, C. H. "Ambientalização curricular" no ensino superior: o caso da Universidade Federal de Rondônia - campus de Porto Velho. 2011.310 f. Tese (Doutorado em Educação Escolar) - Faculdade de Ciências e Letras, Universidade Estadual Paulista Júlio de Mesquita Filho, Araraquara, 2011.

BARBIERI, J. C. Gestão ambiental Empresarial: conceitos, modelos e instrumentos. 2ạ ed. São Paulo: Saraiva, 2007.

BASSANI, P. Universidade e sustentabilidade: ensaio introdutório. In: PERCURSOS, 2014. Londrina. Coletânea de trabalhos do PPGA-UEL triênio 2010-2012. Londrina: UEL, 2014. P. 221-232.

BEATRICE, C. O ensino de projeto de arquitetura face à ética ambientalista. In: VI EDUCERE, 2006. Curitiba. CD dos Anais, do VI EDUCERE - CONGRESSO NACIONAL DE EDUCAÇÃO DA PUCPR - PRAXIS, IBSN 85-7292-166-4. Disponível em: < http://www.pucpr.br/eventos/educere/educere2006/anaisEvento/docs/CI-305-TC.pdf >. Acesso em 11 fev. 2016

BENEVOLO, L. História da arquitetura moderna. 5ạ edição. São Paulo: Perspectiva, 2014.

. História da cidade. 6ạ edição. São Paulo: Perspectiva, 2015.

BONNET, J. F. et al. Analysis of electricity and water end-uses in university campuses: case-study of the University of Bordeaux in the framework of the Ecocampus European Collaboration. Journal of Cleaner Production, 2002.

BRINKHURST, M.; ROSE, P.; MAURICE, G.; ACKERMAN, J. D. Achieving campus sustainability: top-down, buttom-up, or neither? International Journal of Sustainability in Higher Education, n. 12/4, 2011.

BRONDANI, S. C.; BRANDLI, L. L.; FRANDOLOSO, M. A. L.; VIEIRA, S. Panorama da sustentabilidade ambiental nas melhores universidades da América Latina. Revista AIDIS, México, v. 7, n. 1, p. 1-10, 2014. Disponível em: <http://www.revistas.unam.mx/index.php/aidis/article/view/46599>. Acesso em 11 fev. 2016.

BRUM, A. K.; LERIPIO, A. A.; BACKES, B. I.; PFITSCHER, E. D.; RAUPP, F.; OLIVEIRA, M. V.; SELIG, P. M. Mudança de paradigma na prática de sustentabilidade. XXII Encontro Nacional de Engenharia de Produção, Curitiba, out. 2002. <http://nemac.ufsc.br/files/2012/11/1-ENEGEP2002_TR21_0178.pdf>. Acesso em: 06 de mai. 2016.

BURFORD, G.; HOOVER, E.; VELASCO, I.; JANOUSKOVÁ, S.; JIMENEZ, A.; PIGGOT, G.; PODGER, D.; HARDER, M. K. Bringing the "Missing Pillar" into Sustainable Development Goals: Towards Intersubjective Values-Based Indicators. Sustainability 5, p. 3035- 3059, 2013.

CAMBI, F. História da pedagogia. São Paulo: Unesp, 1999.

CAMPANI, D. B. et al. Implantação do sistema de gestão ambiental na Universidade Federal do Rio Grande do Sul (UFRGS). In: XXV Seminário de Extensão da Região Sul - SEURS, 2007. Guarapuava, Universidade Estadual do Centro-Oeste (Unicentro).

CAMPOS, E. S. História da Universidade de São Paulo. São Paulo, EdUSP, 2004. 
CARAM, A. L. B. Arquitetura e educação superior: projetos e realizações dos engenheiros-arquitetos da Poli. 2014.392 f. Dissertação (Mestrado em Arquitetura e Urbanismo) - Faculdade de Arquitetura e Urbanismo, Universidade de São Paulo. 2014.

CARLETTO, R. D. L.; GUERRA, A. F. S. Programas de educação ambiental: formação docente e metodologias de avaliação. X ANPED SUL, Florianópolis, out. 2014. Disponível em: < http://xanpedsul.faed.udesc.br/arq_pdf/886-0.pdf >. Acesso em: 11 fev. 2016.

CASTILHO, F. O conceito de universidade no projeto da UNICAMP. Campinas: Ed. UNICAMP, 2008.

CAUQUELIN, A. A invenção da paisagem. São Paulo: Martins, 2007.

CHARLE, C.; VERGER, J. História das Universidades. São Paulo: Editora da Universidade Estadual Paulista, 1996.

CHOAY, F. (1965). O urbanismo: utopias e realidades, uma antologia. 7a edição. São Paulo: Perspectiva, 2015.

COORDENADORIA DO ESPAÇO FÍSICO DA UNIVERSIDADE DE SÃO PAULO. Definição de Campus Universitário, 2014.

COULSON, J.; ROBERTS, P.; TAYLOR, I. University Planning and Architecture: the search for perfection. Londres: Taylor \& Francis, 2010.

COSTA, A. I. Sérgio Ferro, didática e formação. 2008. 183 f. Dissertação (Mestrado em Arquitetura e Urbanismo) - Escola de Engenharia de São Carlos, Universidade de São Paulo. 2008.

CUNHA, S. B.; GUERRA, A. J. T. (Org.). (2003). A questão ambiental: diferentes abordagens. 7ạ edição. Rio de Janeiro: Bertrand Brasil, 2012.

DISTERHEFT, A.; CAEIRO, S. S. F. S.; RAMOS, M. R.; AZEITEIRO, U. M. M. Environmental Management Systems (SEM) implementation processes and practices in European higher education institutions- Top-down versus participatory approaches. Journal os Cleaner Production, n. 31, p. 80-90, 2012.

DISTERHEFT, A.; CAEIRO, S. S. F. S.; AZEITEIRO, U. M. M., FILHO, W. L. Sustainable universities- a study of critical success factors for participatory approaches. Journal os Cleaner Production, 2014.

DOBER, R. P. Campus Planning. New York: Reinhold, 1963.

Campus landscape: functions, forms, features. New York: John Wiley \& Sons, 2000.

DOMSCHKE, V.L. O ensino de arquitetura e a construção da modernidade. 2007. 324 f. Teste (Doutorado em Arquitetura e Urbanismo) - Faculdade de Arquitetura e Urbanismo, Universidade de São Paulo. 2007.

DONAIRE, D. Gestão ambiental na empresa. São Paulo: Atlas, 1995. 
DOURADO, B. M. Sobre o ensino da sustentabilidade ambiental nos cursos da arquitetura e urbanismo: avaliação e subsídios. 2015.233 f. Dissertação (Mestrado em Arquitetura e Urbanismo) - Faculdade de Arquitetura e Urbanismo, Universidade de Brasília, Brasília, 2015.

ENGELS, F. (1845). Condition of the Working Class in England. Nova lorque: Panther Edition, 1969.

FARIA, C. R. O.; FREITAS, D. Um projeto socioambiental para o currículo: problematizações e perspectivas para a educação superior. E-cadernos ces, França, n. 2 , 2008. Disponível em: http://eces.revues.org/1356. Acesso em: 11 fev. 2016.

FARTHING, S. Tudo sobre a arte: os movimentos e as obras mais importantes de todos os tempos. Rio de Janeiro: Sextante, 2011.

FERRER- BALAS, D.; ADACHI, J.; BANAS, S.; DAVIDSON, C. I.; HOSHIKOSHI, A.; MISHRA, A.; MOTODOA, Y.; ONGA, M.; OSTWALD, M. An international comparative analysis of sustainability transformation across seven universities. International Journal of Sustainability in Higher Education, Vol. 9, p. 295 - $316,2008$.

FICHER, S. Os Arquitetos da Poli: Ensino e Profissão em São Paulo. São Paulo: Fapesp: Editora da Universidade de São Paulo, 2005.

FOLADORI, G. Avanços e limites da sustentabilidade social. Revista Paranaense de Desenvolvimento, Curitiba, n. 102, p. 103- 113, jan. / jun. 2002. Disponível em: < http://www.ipardes.pr.gov.br/ojs/index.php/revistaparanaense/article/view/214>. Acesso em 11 fev. 2016.

FOUTO, A. R. F. O papel das universidades rumo ao desenvolvimento sustentável: das relações internacionais às práticas locais. 2002 .dissertação (Mestrado em Gestão e Políticas ambientais, Relações Internacionais do Ambiente) - Faculdade de Ciências e Tecnologia, Universidade Nova de Lisboa, Lisboa, 2002.

FRANCO, M. A. R. Planejamento ambiental para a cidade sustentável. 2a edição. São Paulo: Annablume: FAPESP, 2001.

GARRÉ, B. H. L.; HENNING, P. C. A educação ambiental em exame: modos midiáticos na constituição de um sujeito ambiental. X ANPED SUL, Florianópolis, out. 2014. Disponível em: < http://xanpedsul.faed.udesc.br/arq_pdf/864-0.pdf>. Acesso em: 11 fev. 2016.

GIORDAN, M. Z.; GALLI, V. B. Educação ambiental um eixo norteador na mudança de comportamento. X ANPED SUL, Florianópolis, out. 2014. Disponível em: < http://xanpedsul.faed.udesc.br/arq_pdf/191-1.pdf>. Acesso em: 11 fev. 2016.

GODOI, F. R. S. O problema da ampliação recente da universidade pública paulista. Cad. Pes., São Luís, v. 21, n. 2, p. 01-13, mai./ ago. 2014.

Um estudo sobre territórios universitários: o caso de Pirassununga. 2015. 123 f. Dissertação (memorial de qualificação para o Mestrado em Arquitetura e Urbanismo) - Instituto de Arquitetura e Urbanismo, Universidade de São Paulo, São Carlos, 2015.

GONÇALVES, J. C. S.; DUARTE, D. H. S. A arquitetura sustentável: uma integração entre ambiente, projeto e tecnologia em experiências de pesquisa, prática e ensino. Ambiente Construído, Porto Alegre, v. 6, n.4, p. 51-81, out./dez. 2006.

GOODY, J. O roubo da história: como os europeus se apropriaram das ideias e invenções do Oriente. 2a edição da 2ạ reimpressão. São Paulo: Contexto, 2015. 
HALL, P. (1988). Cidades do amanhã: uma história intelectual do planejamento e do projeto urbanos no século XX.1a reimpr. da 2a ed. São Paulo: Perspectiva, 2013.

HERZOG, C. P. Cidade para todos: (re) aprendendo a conviver com a natureza. 1ạ edição. Rio de Janeiro: Mauad X: Inverde, 2013.

HERCULANO, S. C. Do desenvolvimento (in)suportável à sociedade feliz. In: Ecologia, ciência e política. GOLDENBERG, M. (Org.). Rio de Janeiro, Revan, 1992.

HOWARD, E. Cidades- Jardins de amanhã. São Paulo: HUCITEC, 1996.

JACOBI, P. Educação ambiental, cidadania e sustentabilidade. Cadernos de Pesquisa, n. 118, p. 189-205, mar. 2003. Disponível em: < http://www.scielo.br/pdf/cp/n118/16834.pdf>. Acesso em: 11 fev. 2016.

JANOTTI, A. Origens da Universidade. São Paulo: EDUSP, 1992.

KRAEMER, M. E. P. A universidade do século XXI rumo ao desenvolvimento sustentável. Revista Eletrônica de Ciência Administrativa (RECADM), Campo Largo, v. 3, n. 2, nov. 2004. Disponível em:< http://www.spell.org.br/documentos/ver/25049/a-universidade-do-seculo-xxi-rumo-ao-desenvolvimento-sustentavel/i/pt-br >. Acessado em: 11 fev. 2016.

KUHN, T. S. (1962). A estrutura das revoluções científicas. 5ạ edição. São Paulo: Editora Perspectiva AS, 1998.

LANNA, A. L. D. (Org.). Meio Ambiente: Patrimônio Cultural da USP. São Paulo: Editora da Universidade de São Paulo/ Imprensa Oficial do Estado de São Paulo/ Comissão de Patrimônio Cultural, 2003.

LESSA, S. TONET, I. Introdução à Filosofia de Marx. 2a edição. São Paulo: Editora Expressão Popular, 2011.

LEVY, B. L. M.; MARANS, R. W. Towards a campus culture os environmental sustainability. International Journal of Sustainability in Higher Education, n. 13/4, p. 365$377,2011$.

LIMA, G. F. C. O debate da sustentabilidade na sociedade insustentável. Revista Eletrônica "Política e Trabalho", v. 13, p. 201- 222, set. 1997. Disponível em: < http://www.cefestsp.br/edu/eso/debatesustentabilidade.html>. Acessado em: 24 abr. 2016.

LOTUFO, J. O. Habitação social para a cidade sustentável. 2011. 155 f. Dissertação (Mestrado em Arquitetura e Urbanismo) - Faculdade de Arquitetura e Urbanismo, Universidade de São Paulo, São Paulo, 2011.

LOWY, M. Crise ecológica, crise capitalista, crise de civilização: a alternativa ecossocialista. In: Caderno CRH: Salvador, v. 26, p. $79-86$, jan./ abr. 2013.

LOZANO, R. Incorporation and institucionalization of SD into universities: breaking through barriers to change. Journal of Cleaner Production, n. 14 , p. 787- 796, 2006. 
LOZANO, R.; CELEUMANS, K.; ALONSO-ALMEIDA, M.; HUISINGH, D., LOZANO, F.J.; WAAS, T., LAMBRECHTS, W.; LUKMAN, R.; HUGÉ, J. A review of commitment and implementation of sustainable development in higher education: results from a worldwide survey. Journal of Cleaner Production. 2014.

MAHLER, C. R. Territórios Universitários: tempos, espaços, formas. 2015. 304 f. Tese (Doutorado em Arquitetura e Urbanismo) - Faculdade de Arquitetura e Urbanismo, Universidade de Brasília, Brasília, 2015.

MAQUETTO, L., MONTEIRO, S. E.; BAIALARDY, T. Princípios e padrões de Cristopher Alexander: aplicados ao estudo de intervenção em um campus universitário. In: XI SEMANA DE EXTENSÃO, PESQUISA E PÓS-GRADUAÇÃO-SEPesq, 11, 2015. Centro Universitário Ritter dos Reis. Anais Sustentabilidade, Ciência e Ética: Responsabilidade Ambiental, Social, Econômica e Cultural. Rio Grande do Sul: XI Semana de Extensão, Pesquisa e Pós-Graduação, 2015.

MARCOMIN, F. E.; SILVA, A. D. V. A sustentabilidade no ensino superior brasileiro: alguns elementos a partir da prática de educação ambiental na Universidade. Contrapontos, Itajaí, v. 9, n. 2, p. 104-117, mai/ago 2009. Disponível em: < http://siaiap32.univali.br/seer/index.php/rc/article/view/999>. Acesso em: 11 fev. 2016.

MARTIN, R. ISO 14001 Guidance Manual, National Centre for environmental decision-making research. Technical report, 1998.

MARTINS, D. F. Sustentabilidade no canteiro de obras. 2010. 90 f. Trabalho final de curso (Graduação em Engenharia Civil) - Escola Politécnica, Universidade Federal do Rio de Janeiro. 2010

MARX, K. A origem do Capital: a acumulação primitiva. São Paulo, Centauro, 2004.

MENDONÇA, A. W. P. C. A Universidade no Brasil. Revista Brasileira de Educação, n. 14, p. 131-194, Mai/ Jun/ Jul/ Ago. 2000. Disponível em: < http://www.scielo.br/pdf/rbedu/n14/n14a08.pdf>. Acesso em: 30 jan. 2016.

MINISTÉRIO DA EDUCAÇÃO. Educação ambiental: aprendizes de sustentabilidade. Cadernos SECAD $1 . \quad$ Disponível em: < http://portal.mec.gov.br/dmdocuments/publicacao2.pdf >. Acesso em 11 fev. 2016.

MONTANER, J. M. A beleza das arquiteturas ecológicas. In: A modernidade superada: ensaios sobre arquitetura contemporânea. São Paulo: Editora G. Gili, 2012. p. 153-169.

MOSTAFAVI, M.; DOHERTY, G. (Org.). (2010). Urbanismo ecológico. São Paulo: Gustavo Gilli, 2014.

MUTZ, A. S. C. A constituição do sujeito contemporâneo do consumo- um desafio para a educação ambiental. X ANPED SUL, Florianópolis, out. 2014. Disponível em: < http://xanpedsul.faed.udesc.br/arq_pdf/895-0.pdf>. Acesso em: 11 fev. 2016.

NOBRE, E. A. C. O ideário urbanístico e a legislação na cidade de São Paulo: do Código de Posturas ao Estatuto da Cidade. IX Seminário de História da Cidade e do Urbanismo, São Paulo, 4 a 6 de setembro de 2006. Disponível em: <http://www.usp.br/fau/depprojeto/labhab/biblioteca/textos/nobre_ideariourb.pdf>. Acesso em: 24 ago. 2015. 
OECD, HIGHER EDUCATION FOR SUSTAINABLE DEVELOPMENT: Final Report of International Action Research Project, Forum for the future, 2007. Disponível em: http://www.oecd.org/ education/innovation- education/centreforeffectivelearningenvironmentscele/45575516.pdf. Acesso em: 16 de fev. 2017.

OLIVEIRA, M. Produção mais limpa como ferramenta de gestão ambiental para as indústrias do município de Juiz de Fora. $2006.78 \mathrm{f}$. Trabalho de conclusão de curso (Graduação em Engenharia de Produção) - Faculdade de Engenharia, Universidade Federal de Juiz de Fora, Juiz de Fora, 2006.

Universidade e sustentabilidade: proposta de diretrizes e ações para uma universidade ambientalmente sustentável. 2009.90 f. Dissertação (Mestrado em Ecologia Aplicada ao Manejo e a Conservação de Recursos Naturais) - Programa de Pós-Graduação em Ecologia, Universidade Federal de Juiz de Fora, Juiz de Fora, 2009.

OLIVEIRA, L. R.; MEDEIROS, R. M.; TERRA, P. B.; QUELHAS, L. G. Sustentabilidade: da evolução dos conceitos à implementação como estratégia nas organizações. Produção, Niterói, v. 22, n. 1, p. 70- 82, 2012.

OLIVEN, A. C. A marca de origem: comparando colleges norte-americanos e faculdades brasileiras. Cadernos de Pesquisa, Maranhão, v. 35, n. 125, p. 111-135, maio / ago. 2005.

ORSI, R. F. M. Ambientalização curricular: um diálogo necessário na educação superior. X ANPED SUL, Florianópolis, out. 2014. Disponível em: < http://xanpedsul.faed.udesc.br/arq_pdf/291-0.pdf >. Acesso em: 11 fev. 2016.

PADUA, S. M.; SÁ, L. M. O papel da educação ambiental nas mudanças de paradigmáticas da atualidade. Revista Paranaense de Desenvolvimento, Curitiba, n. 102, p. 71- 83, jan. / jun. 2002. Disponível em: < http://www.ipardes.pr.gov.br/ojs/index.php/revistaparanaense/article/view/212>. Acesso em: 11 fev. 2016.

PAVESI, A. A ambientalização da formação do arquiteto: o caso do Curso de Arquitetura e Urbanismo da Escola de Engenharia de São Carlos (CAU, EESC- USP). 2007. 199 f. Tese (Doutorado em Educação) - Programa de Pós-Graduação em Educação, Universidade Federal de São Carlos, São Carlos, 2007.

. A Escola de Engenharia de São Carlos (EESC-USP) diante do desafio da ambientalização curricular dos cursos de graduação. Revista de Ensino de Engenharia, v. 30, n.1, p. 24-34, 2011.

. Câmpus universitário: um Compêndio de Idéias para seu Planejamento. XI SHCU-Seminário de história da cidade e do urbanismo, Vitória, out. 2010.

. Cultura, escola e currículo: a inserção da temática ambiental na formação dos arquitetos. In: III EPEA - ENCONTRO PESQUISA EM EDUCAÇÃO AMBIENTAL, 3, 2005. Ribeirão Preto. Anais do III Epea - Encontro Pesquisa em Educação Ambiental. Ribeirão Preto: FFCLRP/USP, Unesp/Rio Claro e UFSCar, 2005. P.1-12.

PAVESI, A., FREITAS, D. A problemática socioambiental na formação do arquiteto: perspectivas e desafios apontados por um estudo do currículo de um curso de arquitetura e urbanismo. Revista Risco, São Carlos, n. 7, 2008. Disponível em: < http://www.revistas.usp.br/risco/article/view/44727>. Acesso em: 11 fev. 2016.

PELLEGRINO, P. R. M. (Org.). IEV-CUASO: Plano de Infraestrutura Verde para o campus Cidade Universitária. Disponível em: https://issuu.com/labverde/docs/plano_iev_cuaso. Acesso em: 16 de fev. 2017. 
PELLEGRINO, P. R. M.; CASTAÑER, C. M. Oficina de projeto do LABVERDE para a implantação de infraestrutura verde no campus USP - Cidade Universitária. Revista LABVERDE, São Paulo, n. 9 - Evento, p. 165- 171, dez. 2014. Disponível em: < http://www.revistas.usp.br/revistalabverde/article/view/89900/92697>. Acesso em: 11 fev. 2016.

PEREIRA, G. S. M., JABBOUR, C., OLIVEIRA, S. V. W. B., TEIXEIRA, A. A. Greening the campus of a Brazilian university: Cultural challenges. International Journal of Sustainability in Higher Education, n. 15/ 1, p. 34-47, 2014.

PHILIPPI JÚNIOR, A.; BRUNA, G. C.; Política e Gestão Ambiental. In: PHILIPPI JÚNIOR, A. ROMÉRIO, M. A.; BRUNA, G. C. (Ed.). Curso de Gestão Ambiental. Barueri: Manole, p. 657- 711, 2004.

PHILIPPI JÚNIOR, A. ROMÉRIO, M. A.; BRUNA, G. C. Uma introdução à questão ambiental. In: PHILIPPI JÚNIOR, A. ROMÉRIO, M. A.; BRUNA, G. C. (Ed.). Curso de Gestão Ambiental. Barueri: Manole, p. 03- 16, 2004.

PINTO, G. A.; BUFFA, E. Arquitetura e educação: câmpus universitários brasileiros. São Carlos: EdUFSCAR, 2009.

PNUMA, Programa de las Naciones Unidas para el Medio Ambiente-Industria y Medio ambiente. Producción más limpia: Um paquete de recursos de capaciotación, Ciudad de México: PNUMA/ ORPALC, 1999.

QUINTANA, A. C., HACON, V. O desenvolvimento do capitalismo e a crise ambiental. O Social em Questão, Rio de Janeiro, n. 25/ 26 , p. 427-444, 2011.

RIBEIRO, D. A Universidade Necessária. Rio de Janeiro: Paz e Terra, 1968.

RIBEIRO, A. Campi universitários: desenvolvimento de suas estruturas espaciais. 2008. 218 f. Dissertação (Mestrado em Arquitetura e Urbanismo) - Universidade Presbiteriana Mackenzie, São Paulo, 2008.

RODRIGUES, M. A. Subsídios para avaliação da qualidade ambiental de campi universitários. 2002. 195 f. Dissertação (Mestrado em Engenharia Civil) - Faculdade de Engenharia Civil, Universidade Estadual de Campinas, Campinas, 2002.

ROGERS, P. (1997). Cidades para um pequeno planeta. 1a edição, 7ạ impressão. Barcelona: Editorial Gustavo Gili, 2014.

ROHDE, G. M. Mudanças de paradigma e desenvolvimento sustentado. In: CAVALCANTI, C. (Org.). Desenvolvimento e natureza: estudos para uma sociedade sustentável. Recife: INPSO-FUNDAJ, Instituto de Pesquisas Sociais-Fundação Joaquim Nabuco, 1994. p. 22- 29.

ROORDA, N. Auditing Instrument for Sustainability in Higher Education. Dutch fundation on sustainable Higher Education and the Dutch Ministry of Environmental Affairs, Escócia, 2001.

RUSCHEINSKY, A. et al. (Org.). Ambientalização nas instituições de educação superior no Brasil: caminhos trilhados, desafios e possibilidades. 1ạ edição. São Carlos: EESC/ USP, 2014. 
SACHS, I. Caminhos para o desenvolvimento sustentável. 3ạ edição. Rio de Janeiro: Garamond, 2008.

Desenvolvimento includente, sustentável, sustentado. Rio de Janeiro: Garamond, 2004.

Environment and styles of development. In: MATTHEWS (org.) (1976) Outer limits and human needs. Resources and environmental issues on development

strategies. Uppsala, Dag-Hammarskjöld Foundation. p. 41- 65.

Ecodesenvolvimento: Crescer sem destruir. São Paulo: Vértice, 1986.

SALOMÃO, B. Origens Históricas da Universidade Ocidental: das Corporações à Formação dos Intelectuais (séculos XII e XIV). Revista Tessituras, Pelotas, n. 3, jul. 2011. ISSN: 2177-0441

SCHENK, L. B. M. Arquitetura da paisagem- entre o Pitoresco, Olmsted e Moderno. 2008. 162 f. Tese (Doutorado em Arquitetura e Urbanismo) - Escola de Engenharia de São Carlos, Departamento de Arquitetura e Urbanismo, Universidade de São Paulo, São Carlos, 2008.

SCHENK, L. B. M. A inserção do novo campus universitário da USP na cidade de São Carlos (SP, Brasil): convergências e dissensões na construção de uma paisagem exemplar. In: LEME, P. C. S.; PAVESI, A.; ALBA, D.; GONZÁLEZ, M. j. D. (Org.). Visões e Experiências Ibero-Americanas de sustentabilidade nas universidades. São Carlos: Gráficas Alhambra, 2011. p. 89-95.

SCHWARTZMAN, S. A universidade primeira do Brasil: entre intelligentsia, padrão internacional e inclusão social. Estudos Avançados, São Paulo, vol. 20 , n. 56, 2006.

SCHWEIGERT, R. Plano diretor e sustentabilidade ambiental da cidade. 2007. 143 f. Dissertação (Mestrado em Arquitetura e Urbanismo) - Universidade Presbiteriana Mackenzie, São Paulo, 2007.

SEGALÀS, J.; MULDER, K. F., FERRER- BALAS, D. What do EESD "experts" think sustainability is? Which pedagogy is suitable to learn it? Results from interviews and Cmaps analysis gathered as EESD 2008. International Journal of Sustainability in Higher Education, n. 13/3, p. 293-304, 2012.

SEIFFERT, M. E. B. ISO 14001- Sistemas de Gestão Ambiental: Implantação objetiva e econômica. 3a ed. São Paulo: Atlas, 2007.

SILVA, J. B.; PASQUALETTO, A. Os caminhos dos parques urbanos brasileiros: da origem ao século XXI. Estudos, Goiânia, v. 40, n. 3, p287-298, jun./ago. 2013. Disponível em: <http://seer.ucg.br/index.php/estudos/article/viewFile/2919/1789>. Acesso em: 25 ago. 2015.

SILVA, G. C.; SILVA, F. L.; PRINTES, L. B.; CUNHA-SANTINO M. B. Avaliação da degradação ambiental na microbacia do Córrego Mineirinho, São Carlos- SP. V Congresso Brasileiro de Gestão Ambiental, Belo Horizonte, nov. 2014. Disponível em: < http://www.ibeas.org.br/congresso/Trabalhos2014/VIII-067.pdf>. Acesso em 19 fev. 2017.

SINGER, P. O Brasil no contexto do capitalismo internacional: 1889- 1930. In: FAUSTO, B. (org.). História geral da civilização brasileira. Rio de Janeiro: Ed. Bertrand Brasil, 1989. V. 1. 
SPIRN, A. O jardim de granito: a natureza no desenho da cidade. São Paulo: Edusp, 1995.

STEVENS, G. O círculo privilegiado: Fundamentos sociais da distinção arquitetônica. Brasília: Editora Universidade de Brasília, 2003.

TAUCHEN, J.; BRANDLI, L. L. A gestão ambiental em instituições de ensino superior: modelos para implantação em campus universitário. Revista Gestão e Produção, v. 13, n. 3, p. 503-515, set. /dez. 2006.

TAUCHEN, J.; RIGO, D. S.; FRANDOLOSO, M. A. L.; BRANDLI, L. L. A sustentabilidade inserida na elaboração de um Plano Diretor de campus: estudo de caso na FAHOR. In: Encontro Latino Americano de Universidades Sustentáveis: Universidades sustentáveis - possibilidades e desafios. Universidade de Passo Fundo, Brasil. Anais, ELAUS, 2008.

TIETZ, J. História da arquitectura contemporânea. Berlim: h.f.ullmann, 2008.

TINOCO, J. E. P.; KRAEMER, M. E. Contabilidade e Gestão Ambiental. São Paulo: Atlas, 2007.

TOMÁS, D. Acciones ambientales en el entorno de las universidades españolas. In: VI Conferencias sobre el Medio Ambiente: Acciones para la preservación del medio ambiente. Castellón: Universitat Jaume I de Castellón, 2003.

TOMMASIELLO, M. G. C.; GUIMARÃES, S. S. M. Sustentabilidade e o papel da universidade: desenvolvimento sustentável ou sustentabilidade democrática? Revista de Educação do Cogeime, ano 22, n. 43, jul./ dez. 2013. Disponível em: <http://dx.doi.org/10.15599/0104-4834/cogeime.v22n43p11-26>. Acesso em: 11 fev. 2016.

TORRE DE MARFIM: A CRISE UNIVERSITÁRIA AMERICANA (IVORY TOWER). Direção e roteiro de Andrew Rossi. Noruega: Paramount Home Media Distribution/ Samuel Goldwyn Films/ CNN Films Production, 2014. Documentário (90 min), color.

TURNER. P. V. (1987). Campus: an american planning tradition. Cambridge: MIT Press, 1995.

ULLMANN, R. A. A Universidade Medieval. 2ª̣ edição. Porto Alegre: EDIPUCRS, 2000.

ULLMANN, R.; BOHNEN, A. Universidade: das origens à renascença. São Leopoldo: Editora Unisinos, 1994.

UNIVERSIDADE FEDERAL DE LAVRAS. Eco Universidade: Plano Ambiental para uma universidade socioambientalmente correta. Disponível em: http://repositorio.enap.gov.br/handle/1/281. Acesso em: 20 de fev. 2016.

Universidade ambientalmente correta. Disponível em: http://ufla.br/relatoriogestao2004-2012/wp-content/uploads/2012/07/UniversidadeAmbientalmente-Correta.pdf. Acesso em:20 de fev. 2016.

VELAZQUEZ, L.; MUNGUIA, N.; PLATT, A.; TADDEI, J. Sustainable university: what can be the matter? Journal of Cleaner Production, n. 14, p. 810-819, 2006. 
VELÁSQUEZ, L. ZAVALA, A. MUNGUÍA, N. Sustainability on campus by implementing the ISO 14001 framework: experiences from the first ISO 14001 certified Latinamerican public university. In: Presentations, International Conference on Environmental Management for Sustainable Universities: A new knowledge culture, Universities facing global changes for sustainability. EMSU, Barcelona, 2008.

VERGER, J. As Universidades na Idade Média. São Paulo: Unesp, 1990.

VILLELA, D. S. A sustentabilidade na formação atual do arquiteto e urbanista. 2007. 183 f. Dissertação (Mestrado em Arquitetura e Urbanismo) - Escola de Arquitetura, Universidade Federal de Minas Gerais, Belo Horizonte, 2007.

WACHHOLZ, C. B. A sustentabilidade na universidade: o desafio da ambientalização na Pontifícia Universidade Católica do Rio Grande do Sul. XANPED SUL, Florianópolis, out. 2014. Disponível em: < http://xanpedsul.faed.udesc.br/arq_pdf/1729-0.pdf>. Acesso em: 11 fev. 2016.

WALLERSTEIN, Immanuel. Ecologia e custos capitalistas de produção: sem saída. In: . O fim do mundo como o concebemos: ciência social para o século XXI. Rio de Janeiro: Revan, 2002.

WELZER, H. Guerras Climáticas: Por que Mataremos e Seremos Mortos no Século 21. Belo Horizonte: Geração Editorial, 2010.

WHIGHT, T., HORST, N. Exploring the ambiguity: what faculty leaders really think os sustainability in higher education. International Journal os Sustainability in Higher Education, n. 14/ 2, p. 209- 227, 2013.

WILLIS, R.; CLARK, J. W. The Architectural History of the University of Cambridge. Cambridge: University Press, 1886.

XAVIER, S. P. A temática da sustentabilidade no ensino de graduação em arquitetura e Urbanismo: estudo de caso das experiências de três instituições públicas. 2011. 171 f. Dissertação (Mestrado em Construção Civil) - Programa de Pós-Graduação em Construção Civil, Universidade Federal do Paraná, Curitiba, 2011. 


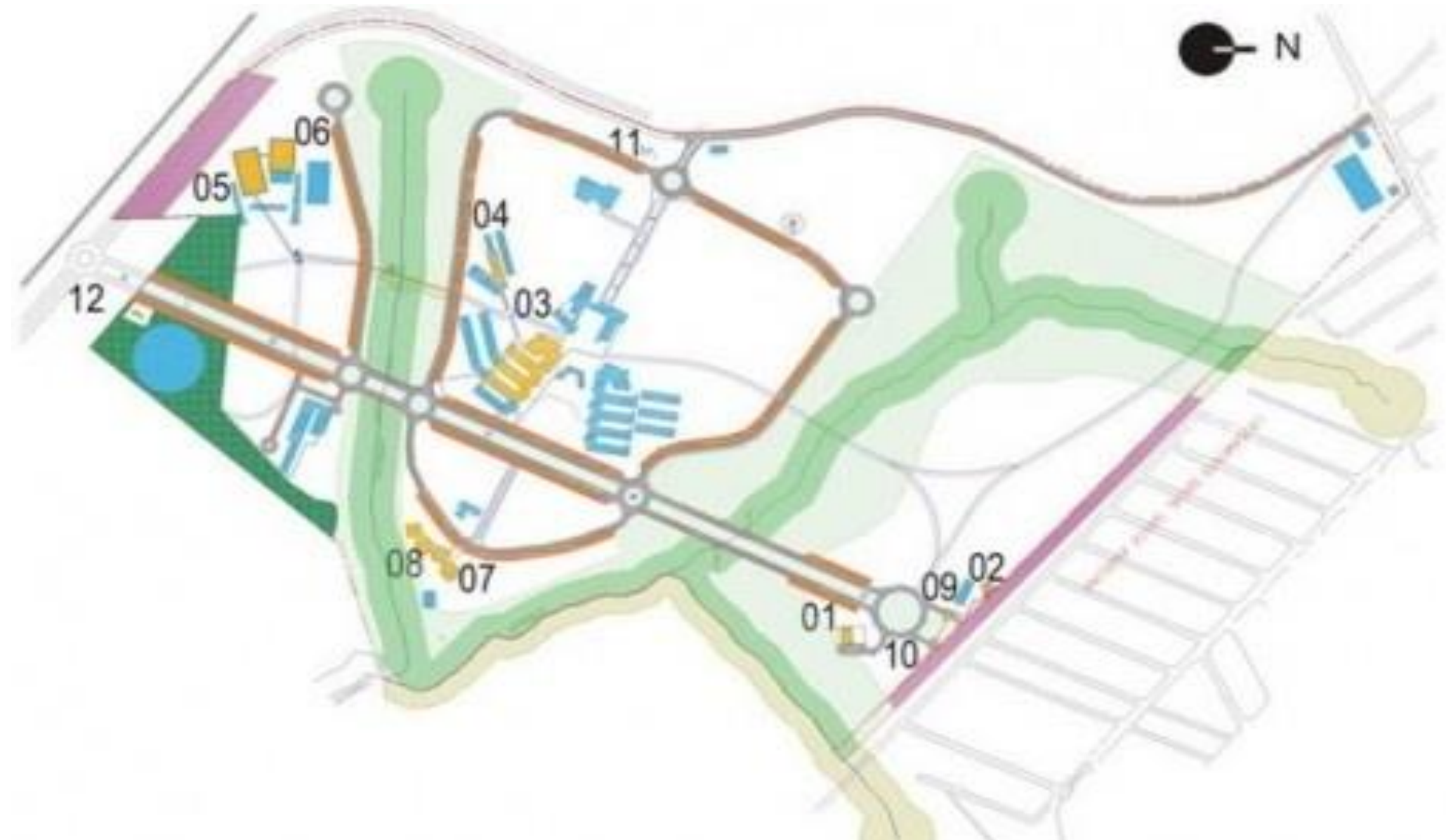

ANEXOS 
Projeto de urbanismo criado pela equipe do professor dr. Carlos R. M. de Andrade para o campus 2 da USP São Carlos. (Essa imagem é também a capa desta dissertação). (Fonte: http://www.vitruvius.com.br/revistas/read/arquitextos/17.197/6261, acessado dia 19 de fevereiro de 2017, as 18:17 hrs). Editada pela autora. 


\section{ANEXO A}

Comissão de Implantação do Campus 2 USP S. Carlos

\section{Proposta de diretrizes para elaboração de Plano Diretor de Ocupação da} Área 2 do Campus de São Carlos

Prof. Carlos Martins, Arq. Sérgio Assumpção, Prof. João Marcos Lopes, Eng. Cilene Garcia, Prof. Carlos Pimenta.

\section{Introdução}

O Grupo de trabalho foi encarregado de propor à Comissão de Implantação do Campus II uma proposta de diretrizes para a elaboração de um Plano Diretor de desenvolvimento físico da área Il do Campus de São Carlos em reunião realizada em março de 2011.

Uma primeira apresentação das propostas preliminares foi apresentada à CICll em agosto de 2011.

Nessa oportunidade, por decisão da CICll, incorporou-se ao GT o Prof. Pimenta.

Neste intervalo de tempo o Grupo de Trabalho desenvolveu propostas de adequação do subsistema plano viário à grelha ordenadora e também distintas propostas de adequação das novas diretrizes, aprovadas em principio pela CICll, às demandas concretas da EESC e do ICMC em relação a projetos de ocupação do setor 2 .

A segunda versão, elaborada pelo GT em 02/mar/2012, foi aprovada, com sugestões de acréscimos pela CIC Il em 20/abril/2012.

A presente versão, resultado de reunião do GT em maio 2012, essencialmente avança no detalhamento d a proposta de normatização do processo de elaboração de projetos.

\section{Plano Diretor}

Um Plano Diretor é um conjunto de instrumentos normativos, que tem por objetivo central buscar um desenvolvimento físico territorial orgânico, otimizado e adequado aos objetivos institucionais da Instituição promotora. Neste caso, trata-se de otimizar o processo de 
ocupação da área 2 do Campus de São Carlos, otimizando a sua condição de ativo fundamental para o desenvolvimento institucional da USP em São Carlos.

Um Plano Diretor, observadas as especificidades de sua abrangência, deve estar apoiado em:

- diagnóstico,

- zoneamento,

- prognóstico de tendências de desenvolvimento,

- normas de uso e ocupação do solo,

- proposição de instrumentos de acompanhamento

- avaliação e revisão periódicas

\section{Objetivos}

O objetivo geral e central da proposta elaborada por este Grupo de Trabalho, consoante com solicitação apresentada pela CICII, é o de otimizar o processo de ocupação da Área 2, em consonância com os objetivos acadêmicos da criação do Campus, evitando a repetição dos problemas de ocupação do Campus 1 e adequar a ocupação física a um planejamento acadêmico estratégico (USP S. Carlos 2021).

\section{Objetivos especificos}

No âmbito do planejamento físico, os objetivos gerais acima indicados podem ser detalhados na perspectiva de:

- Ampliar o CA -coeficiente de aproveitamento- (área construída/área do terreno),

- Diminuir a TO - taxa de ocupação- (projeção da construção/área do terreno);

- Ampliar as taxas de permeabilidade e de cobertura vegetal;

- (* O GT se propõe a apresentar propostas de (A, TO, CP e CV)

- Ampliar a peatonalidade e defini-la como modal de deslocamento preferencial nas áreas centrais da Área ll;

- Ampliar de maneira significativa as práticas e procedimentos, construtivos e de uso, de caráter sustentável, em especial nos âmbitos de otimização energética, dispositivos de reuso de água, coleta e tratamento de resíduos, etc.

- Otimizar o planejamento da implantação e a gestão de serviços.

\section{Diretrizes gerais}

A elaboração de um Plano Diretor de Ocupação da Área ll deve estar apoiada nas seguintes diretrizes gerais:

- Reforço da concepção de zoneamento temático, considerada como um avanço importante do processo de gestão do Campus;

- Articulação da proposta física de ocupação com o planejamento estratégico acadêmico

- Otimização da ocupação a médio e longo prazos

- Avaliação e revisão periódicas (*o GT sugere a adoção de 2016 como momento de revisão) 


\section{Diretrizes fisicas}

Os objetivos gerais e especificos acima propostos demandam o estabelecimento das seguintes diretrizes fisicas para o planejamento e projeto dos novos edificios e das redes de

equipamentos e infraestrutura da Área Ill.

- Adequação da implantação à insolação e ao regime de ventos;

- Estímulo à verticalização (adensamento da ocupação e ampliação das áreas livres);

- Estímulo à racionalização de projetos, processos e sistemas construtivos;

- Garantir as condições para o deslocamento pedestre como modal de transporte

preferencial na zona central da área II;

- Estabelecer áreas e bolsões periféricos de estacionamento.

- Implementar sistemas e práticas sustentáveis tanto na construção como no uso das instalações fisicas da área ll.

\section{Instrumentos fisicos}

A aplicação ao longo do tempo das diretrizes físicas acima indicadas deve estar apoiada em um conjunto de instrumentos de planejamento fisico, dentre os quais se destacam.

- Estabelecimento de uma Grelha Virtual para a definição de implantação de novos edifícios e equipamentos;

- Adequação do Sistema Viário projetado e dos sistemas de redes e serviços à grelha virtual

- Definição de parâmetros de construção (Coeficiente de Aproveitamento; Taxa de Ocupação; Taxa de Permeabilidade e cobertura vegetal; Gabaritos máximos e mínimos; normas de recuos e afastamentos).

Elementos de definição da Grelha Virtual

A proposta de grelha virtual levou em consideração os seguintes aspectos:

- Estudos de Insolação e Regime de Ventos em S. Carlos, bem como diretrizes de orientação para implantação otimizada, elaborados pela COESF;

- Topografia do Campus:

- Sistema Viário já implantado;

- Construçōes existentes e projetos em andamento

- Normas e parâmetros de dimensionamento de espaços universitários, elaborados pela COESF;

- Normas de recuos e afastamentos de novas edificaçōes elaborados pela COESF.

Desses parâmetros resultou a proposição de um módulo base retangular de 11,70 × 21,60 metros lineares.

Esse módulo não configura um"lote" mas a projeção de novas construções. Isto significa que observância de recuos e afastamentos é exterior ao módulo e não interna.

Em anexo, proposta de aplicação da malha ao conjunto do Campus. 
Proposta preliminar de dimensão do módulo de ocupação

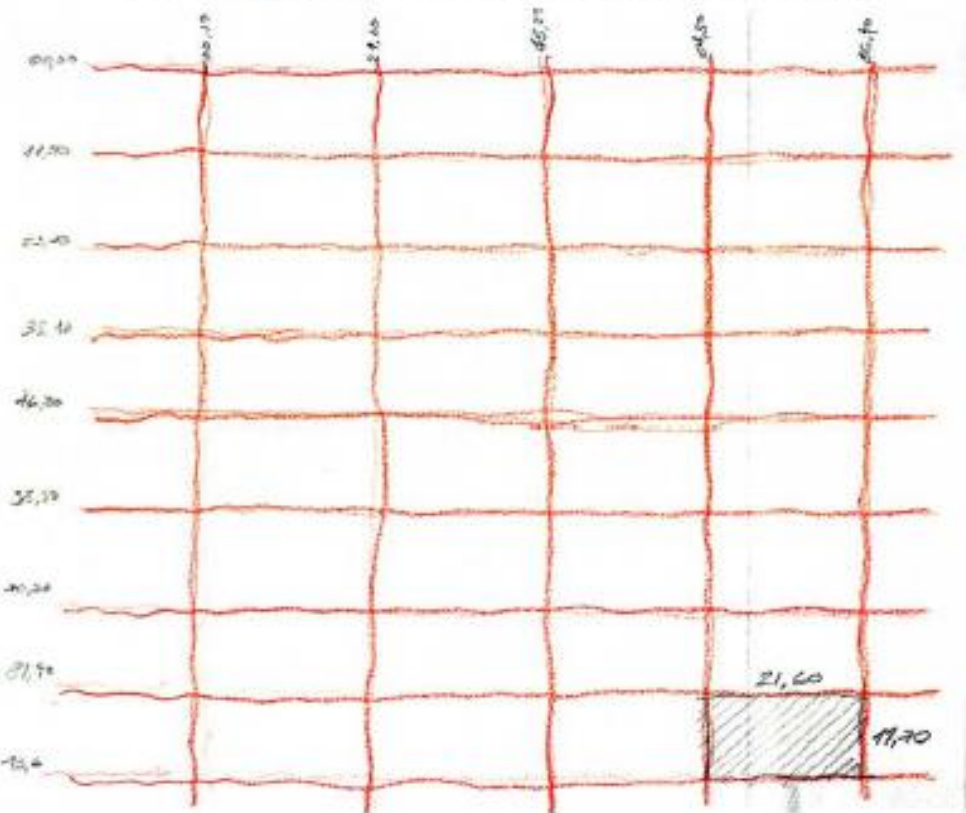


Possibilidades de articulação do módulo de ocupação

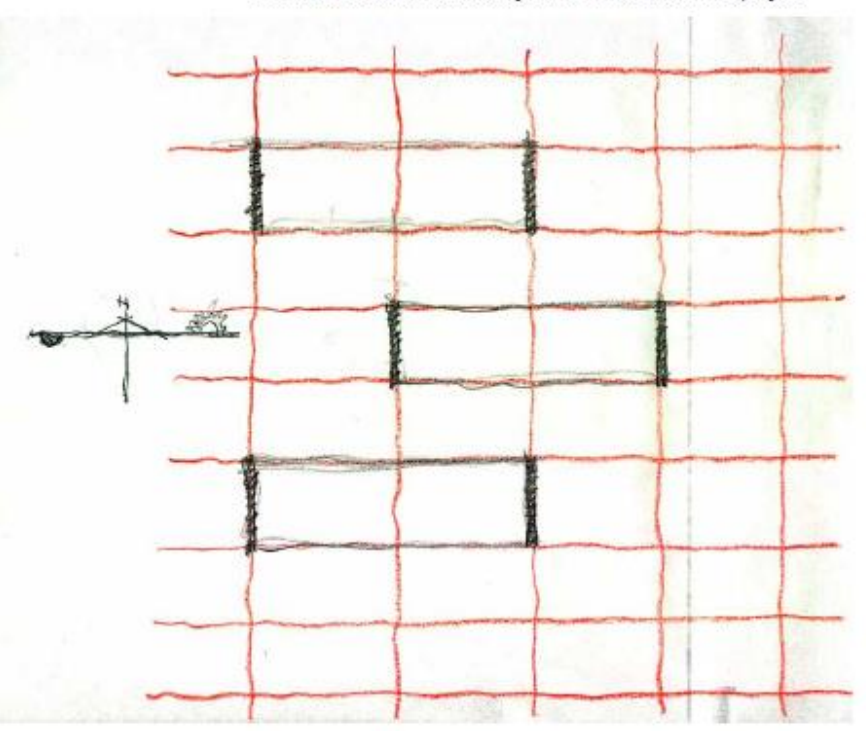

Possibilidades de expansão horizontal direcionadas pela grelha

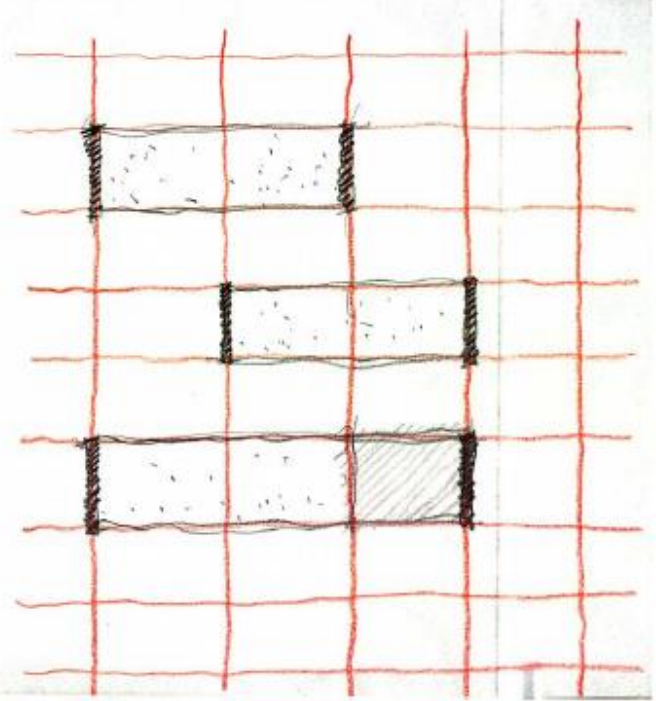


Flexibilidade de ocupação por tipologias especificas

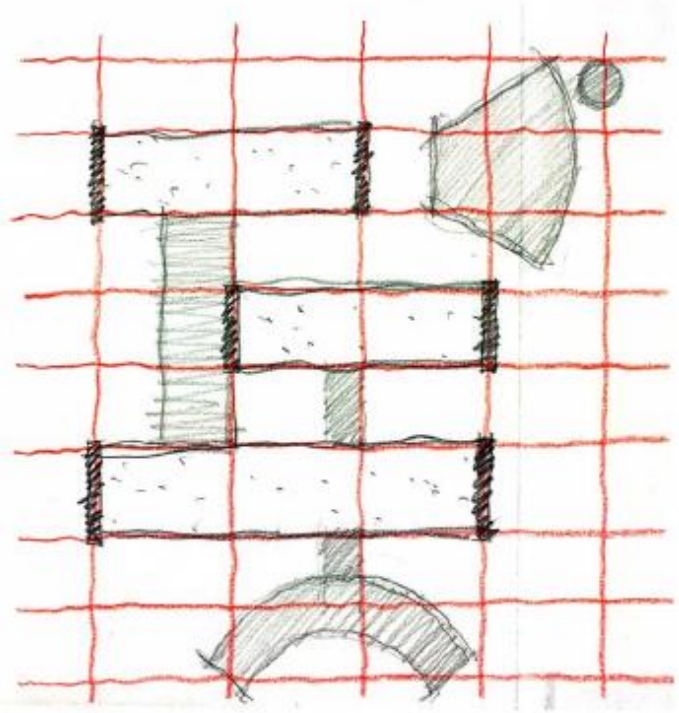

Exemplo esquemótico de aplicação da grelh

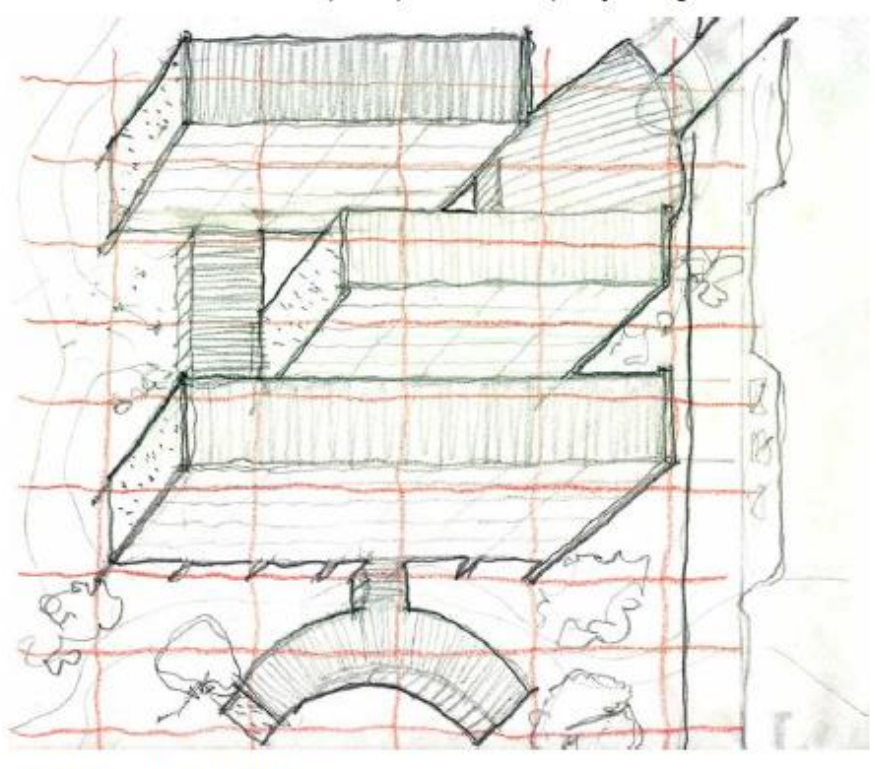

Principios complementares 
Na elaboração do Plano Diretor deverão ser considerados, ainda, os seguintes princípios complementares:

- Prioridade para Bolsões de estacionamento periféricos;

- Ênfase e apoio a mobilidade peatonal, ciclovias e transporte coletivo;

- Diretrizes de sustentabilidade na ocupação física do campus, incluindo racionalização energética; reuso de água; política de residuos sólidos (USP Recicla)

\section{Normatização do processo de elaboração de projetos}

A partir dos principios e diretrizes expostos acima e da experiência com o processo de definição de implantação dos novos edificios no setor temático 2, propõe-se os seguintes passos para elaboração de novos projetos, sejam eles realizados pela CEF ou contratados pelas Unidades:

1) Interessado (Unidade, CICll, PUSC ou SEF) apresenta justificativa acadêmica ou técnica, programa de necessidades, estimativa de área, cronograma inicial, estimativa de custo e fontes de recursos para nova edificação;

2) Comissão Acadêmica discute e aprova definição de finalidade, área física estimada e localização em uma das áreas temáticas;

3) Comissão Acadêmica envia à SEF/ERSC (ao GT enquanto ele estiver ativo) a proposta aprovada;

4) SEF/ERSC (GT enquanto estiver ativo) apresenta à Unidade responsável diretrizes de ocupação e proposta de implantação:

5) Comissão de Implantação do Campus II aprova proposta de implantação ;

6) SEF e Unidade responsável avaliam adequação de estudo preliminar :

7) SEF e Unidade responsável definem responsabilidades por licitação, acompanhamento e fiscalização de projeto e obra.

\section{Continuidade de Trabalho do GT}

A partir da aprovação deste documento parcial de diretrizes para a elaboração do Plano Diretor da Ocupação do Campus II, o Grupo de Trabalho poderia dar continuidade ao seu trabalho, priorizando a elaboração de Caderno de Normas para elaboração de projetos abrangendo, dimensionamento, sistemas construtivos, instalações, princípios de sustentabilidade,etc.)

ANEXO A- Proposta de diretrizes para elaboração de Plano Diretor de Ocupação da Área 2 do Campus de São Carlos elaborada pela Comissão de Implantação do Campus 2 USP S. Carlos.

(Fonte: http://www.ccsc.usp.br/arquivos/diretrizes_ocup\%20Campus_2_ago\%2013.pdf, acessado dia 24 de fevereiro de 2017, as 14:56 hrs). 


\section{ANEXO B}

\section{PORTARIA GR No 6.664, DE 07 DE MAIO DE 2015.}

Cria a Comissão de Planejamento Acadêmico do Campus USP de São Carlos.

O Reitor da Universidade de São Paulo, usando de suas atribuições legais, nos termos do artigo 42, I, do Estatuto da USP, baixa a seguinte

\section{PORTARIA:}

Artigo $1^{\circ}$ - Fica criada, junto ao Gabinete do Reitor, a Comissão de Planejamento Acadêmico do Campus USP de São Carlos.

Artigo $2^{\circ}$ - Compete à Comissão criada no artigo anterior:

I. elaborar planos plurianuais e diretrizes acadêmicas para o desenvolvimento do Campus USP de São Carlos;

II. elaborar diretrizes de planejamento do Campus USP de São Carlos a serem incorporadas à elaboração do Plano Diretor de Desenvolvimento Físico e Urbanístico das diversas áreas que compõem o Campus de São Carlos;

III. aprovar quanto ao mérito acadêmico e indicar os setores adequados para as propostas de construção de novas edificações ou equipamentos no Campus;

IV. elaborar proposta de otimização da estrutura administrativa do Campus USP de São Carlos.

Artigo $3^{\circ}$ - A Comissão de Planejamento Acadêmico do Campus USP de São Carlos fica composta pelos seguintes membros:

I. o Diretor da Escola de Engenharia de São Carlos;

II. o Diretor do Instituto de Arquitetura e Urbanismo;

III. o Diretor do Instituto de Ciências Matemáticas e de Computação;

IV. o Diretor do Instituto de Física de São Carlos;

V. o Diretor do Instituto de Química de São Carlos;

VI. o Prefeito da Prefeitura do Campus USP de São Carlos; 
VII. o Chefe do Escritório Regional da Superintendência do Espaço Físico da USP em São Carlos;

VIII. 01 (um) representante discente, aluno do Campus USP de São Carlos, a ser eleito dentre os seus pares.

$\S 1^{\circ}$ - A presidência da Comissão deverá ser ocupada por um dos membros indicados nos incisos I a V, em esquema de rodízio, com mandato de um ano, sendo o Presidente eleito pelos seus pares.

$\S 2^{\circ}$ - A secretaria da Comissão será realizada por um Assistente Técnico da Unidade cujo Diretor estiver no exercício da Presidência, nos termos do parágrafo anterior.

Rua da Reitoria, 374 - Cidade Universitaria - 05508-220 - São Paulo - SP- Brasi Tel.: (55-11) 3091-3500/ 3812-6200

$\S 3^{\circ}$ - Caso ocorra o término do mandato do Diretor que estiver no exercício da presidência da Comissão de Planejamento Acadêmico do Campus USP de São Carlos, proceder-se-á a uma nova eleição.

Artigo $4^{\circ}$ - Esta Portaria entra em vigor na data de sua publicação, ficando revogadas as Portarias GR nºs 3.318 e 3.319 , de 14.01 .2002 , e $\mathrm{n}^{\circ} \mathrm{s} 4.931$ e 4.932 , de 18.02.2011.

\section{Reitoria da Universidade de São Paulo, 07 Malo 2015}

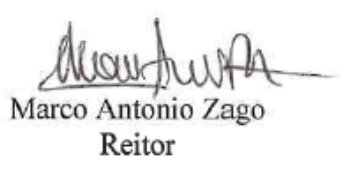

ANEXO B- Portaria GR No 6.664, de 07 de maio de 2015, criadora da Comissão de Planejamento Acadêmico do Campus USP de São Carlos. (Fonte: http://www.prefeitura.sc.usp.br/boletim_informegeral/pdf/portaria_gr_6664_2015.pdf, acessado dia 24 de fevereiro de 2017, as 15:03 hrs). 